\title{
Uma ferramenta para notação musical em braille
}

\author{
Arthur Piza Mosterio Tofani \\ DissertaÇÃo APRESENTADA \\ $\mathrm{AO}$ \\ Instituto de Matemática e Estatística \\ DA \\ Universidade DE SÃo Paulo \\ PARA \\ OBTENÇÃO DO TÍTULO \\ $\mathrm{DE}$ \\ Mestre em CiênCias
}

Programa: Ciência da Computação

Orientador: Prof. Dr. Marcelo Gomes de Queiroz

São Paulo, julho de 2012 
Esta é a versão original elaborada pelo candidato Arthur Piza Mosterio Tofani, tal como submetida à comissão julgadora. 


\section{Agradecimentos}

Ao meu pai Roberto, pelo seu apoio incondicional, que sem dúvida foi fundamental para a realização deste trabalho.

À minha mãe Carmen, por todo o carinho e atenção, e aos meus irmãos, Daniel e Kiko.

Ao Prof. Dr. Marcelo Gomes de Queiroz, orientador deste trabalho, por toda sua atenção, disposição, rigorosidade e assertividade.

Às pessoas incríveis que conheci durante a realização deste trabalho, e que contribuíram para a sua realização: Lara Syaulis, Fabiana Bonilha, Isabel Bertevelli, Vilson Zattera, Rafael Vanazzi, Raphael Ota, Fábio Bonvenuto, Profa. Lucia Filgueiras, Davi Batista e família, Lucas Sperandio e família, Marcela Trevisani, Jacyra Almeida Prado, Gisele e Reginaldo.

Aos colegas do COMPMUS: Santiago Dávila, Leandro "Barba" Thomaz, Flavio Schiavoni, André Bianchi, Alexandre Porres, Danilo Bellini, Antônio, Márcio, Gilmar, DJ.

Agradeço também ao pessoal do CEPA: Alexandre, Brunno, Diego, Mary, Luciano e demais, mas principalmente ao Ivan, por ser compreensivo, paciente e (por várias vezes) genial.

Às pessoas que acompanharam de perto este trabalho, torcendo e apoiando: Nicóli, Rodrigo EBA!, Renato Spinosa, Gustavo Sarzi, Glauber de Bona, Gleyce Noda, Ricardo Separovic, Danton Nunes, Ana Maria Barbosa (Rede Saci), Carlos Lopes, Dionysio, Benilton, Guilherme, Otavio, Vivi, Rafael Carvalho, Bruno Donadio, Patricia Fincatti, Daniel e Simone Dantas, Chico e Elisa Pereira. 


\section{'Oøov Y̌̃ $\mu \eta \delta \grave{\varepsilon} v$ ö $\lambda \omega \varsigma \sigma \grave{v} \lambda v \pi \circ \grave{v}$

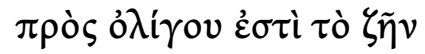

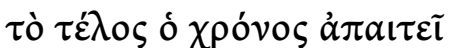

Enquanto viver, brilhe Não sofra por nada Porque a vida é curta E o tempo a conduz para o final

Epitáfio de Seikilos

O mais antigo registro de notação musical conhecido, foi grafado na pedra, em relevo. 


\section{Resumo}

TOFANI, A.P.M., Uma ferramenta para notação musical em braille, Dissertação de Mestrado, Instituto de Matemática e Estatística, Universidade de São Paulo, 2012

O presente trabalho investiga as dificuldades enfrentadas por deficientes visuais ao ingressarem em um curso de nível superior em Música, onde a troca de informação musical escrita é frequente e se dá por meio de partituras impressas em tinta, e a conversão deste material para braille demanda conhecimentos específicos e disponibilidade de recursos. Igualmente problemática, a produção musical do aluno cego é feita em braille, seja para tomar nota de aulas como para realizar tarefas de disciplinas como Contraponto, Harmonia e Análise Musical, ou mesmo para a realização de exames. Claramente, esse material deve passar por um processo de conversão para que o professor possa avaliar o aluno, entre outros motivos.

O foco principal da pesquisa realizada é a análise da musicografia braille sob a ótica das possibilidades de se produzir transcrições automáticas entre partituras em braille e tinta, a fim de prover recursos tecnológicos direcionados à solução deste problema. Para tanto, foi desenvolvido um aplicativo capaz de receber informação musical em braille e convertê-la para o formato MusicXML, adequado para a leitura a partir de outros aplicativos de notação musical e, consequentemente, a impressão deste material em tinta. Este programa está sendo distribuído como software livre sob licença LGPL, contrapondo-se às suas alternativas hoje existentes no mercado.

O aplicativo desenvolvido foi utilizado e avaliado por usuários deficientes visuais e com visão normal por meio de um questionário. Os dados foram então analisados, buscando mapear as diferenças nas experiências de uso e verificar necessidades de melhorias e novas funcionalidades, buscando com isso o aprofundamento nas questões pertinentes ao problema e dando suporte a novas pesquisas relativas ao assunto.

Keywords: musicografia braille, tecnologia assistiva, notação musical.

Abstract 


\section{Abstract}

TOFANI, A.P.M., A tool for braille music notation, Master's thesis, Instituto de Matemática e Estatística, Universidade de São Paulo, 2012

This work researches visually-impaired person's difficulties when studying music as a university career, where musical information is usually forwarded as ink-printed sheet music and the translation of this material to braille involves specific skills and resource availability. In that sense, the musical production demanded from a blind student is accomplished by using braille notation, for taking notes or producing homework for disciplines like Harmony, Musical Analysis, or even to take tests. Clearly the information produced has to be submitted to a conversion process, and finally it can be reviewed by the professor or other students.

The main focus of this research is the understanding of braille music aspects and the problem of generating automatic ink-printed sheet music transcriptions, providing assistive resource for music students. For attaining this goal, an application was developed in order to receive braille music input and translate it to MusicXML format, which can be read by any of the widely MusicXMLcompatible softwares available for reading, editing and printing music. The program is distributed as free software under LGPL license, as opposed to currently available alternatives.

The resulting application was tested by visually-impaired and non-visually impaired users, and reviewed trough the application of a survey. The collected data was analyzed, in search for variations on user experience and checking for software improvement needs, as well as uncovering further relevant matters on this subject.

Keywords: braille music, assistive technology, music notation. 


\section{Sumário}

Lista de Abreviaturas $\quad$ xiii

Lista de Figuras $\quad$ xv

Lista de Tabelas $\quad$ xvii

1 Introdução $\quad 1$

1.1 Motivação e histórico . . . . . . . . . . . . . . . . . . . . 2

1.2 Inclusão do deficiente visual no ensino superior $\ldots \ldots \ldots \ldots$

1.3 Conceitos fundamentais e desafios . . . . . . . . . . . . . . . . . . 4

1.4 Utilização de computadores por deficientes visuais $\ldots \ldots \ldots$. . . . . . . . . 6

1.5 Grupos de pesquisa e trabalho relacionados . . . . . . . . . . . . . 7

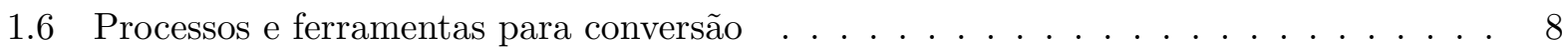

1.7 Delius: um aplicativo de notação musical em braille . . . . . . . . . . . . . . . . 11

1.8 Princípios relacionados ao desenvolvimento do Delius . . . . . . . . . . . . . . . 12

2 A Musicografia Braille $\quad 15$

2.1 Histórico . . . . . . . . . . . . . . . . . . . . . . . . . . 16

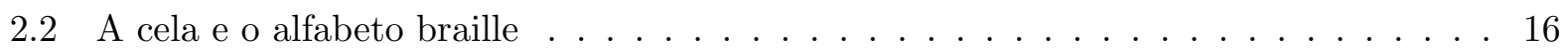

2.3 Símbolos Indicadores do braille . . . . . . . . . . . . . . . . . . . 18

2.4 Elementos musicais . . . . . . . . . . . . . . . . . . . . . . 20

2.5 Uso de indicadores no contexto da musicografia braille . . . . . . . . . . . . . . 25

2.6 Agrupamentos de símbolos . . . . . . . . . . . . . . . . . . . . . . 27

2.7 Aspectos regionais . . . . . . . . . . . . . . . . . . . . 27

2.8 Linhas vocais . . . . . . . . . . . . . . . . . . . . . 27

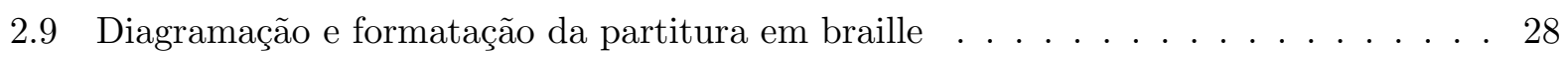

2.10 Conclusão do capítulo . . . . . . . . . . . . . . . . . . . 31

3 Arquitetura do aplicativo $\quad 33$

3.1 Interface do Usuário e Acessibilidade . . . . . . . . . . . . . . . . . . . . 33

3.2 Entrada de Dados e Navegação . . . . . . . . . . . . . . . . . . . . 37

3.3 Disposição da informação musical em uma partitura braille . . . . . . . . . . . . . 40

3.4 Padrão de arquitetura utilizado . . . . . . . . . . . . . . . . . . . . 41

3.5 Demais componentes utilizados . . . . . . . . . . . . . . . . . 47

3.6 Formatos de importação e exportação . . . . . . . . . . . . . . . . . . . . 47

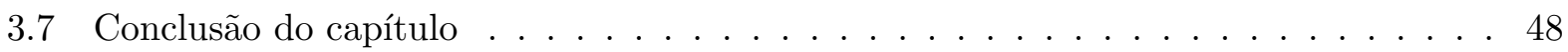


4 Modelos computacionais de representação musical e conversão $\quad 51$

4.1 Principais formatos de representação musical . . . . . . . . . . . . . . . . 53

4.2 Outros formatos de representação musical . . . . . . . . . . . . . . . . 56

4.3 Definição do modelo de representação em objetos . . . . . . . . . . . . . . . . 57

4.4 Produção de informação musical no modelo de representação . . . . . . . . . . . . . 62

4.5 Cálculo de duração das notas . . . . . . . . . . . . . . . . . 66 66

4.6 Questões em aberto relativas ao processo de tradução . . . . . . . . . . . . . . 68

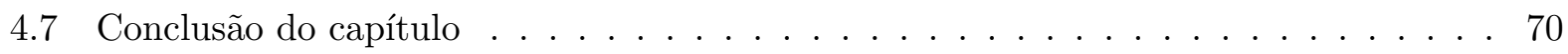

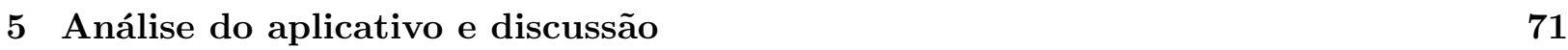

5.1 Introdução . . . . . . . . . . . . . . . . . . . . . . . . . . 71

5.2 Análise de usabilidade e da experiência do usuário . . . . . . . . . . . . . . 71

5.3 Testes de transcrição . . . . . . . . . . . . . . . . . . . . . . . 80

6 Conclusão $\quad 83$

6.1 Necessidades imediatas e passos futuros . . . . . . . . . . . . . . . . . 84

6.2 Considerações finais . . . . . . . . . . . . . . . . . . 85

$\begin{array}{ll}\text { A Questionário aplicado } & 87\end{array}$

$\begin{array}{ll}\text { B Histogramas das respostas dos usuarios } & 97\end{array}$

B.1 Perfil dos entrevistados . . . . . . . . . . . . . . . . . . . . . . 97

B.2 Tarefas realizadas . . . . . . . . . . . . . . . . . . . . 98

B.3 Questões sobre navegação . . . . . . . . . . . . . . . . . . . . . 98

B.4 Questões sobre edição . . . . . . . . . . . . . . . . . . . . . . 99

B.5 Qualidade visual e sonora . . . . . . . . . . . . . . . . . . . 100

B.6 Questões sobre erros do usuário . . . . . . . . . . . . . . . . . . . . . . . . 101

B.7 Avaliações gerais da experiência de uso da ferramenta . . . . . . . . . . . . . . . . 102

$\begin{array}{ll}\text { C Testes de transcrição realizados } & 103\end{array}$

C.1 Teste 1. . . . . . . . . . . . . . . . . . . . . . . . 104

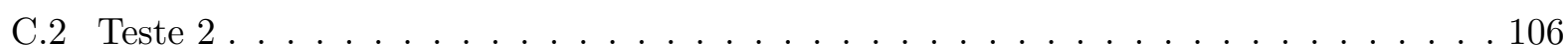

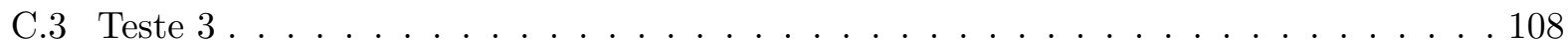

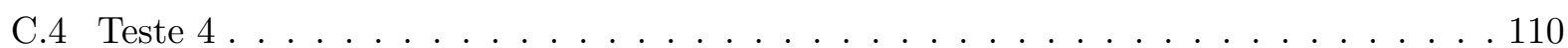

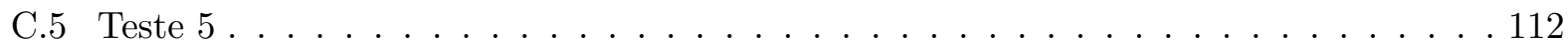

$\begin{array}{ll}\text { D Descrição das regras de musicografia braille no formato BNF } & 117\end{array}$

$\begin{array}{ll}\text { Referências Bibliográficas } & 123\end{array}$ 


\section{Lista de Abreviaturas}

$\begin{array}{ll}\text { BNF } & \text { Backus-Naur Form } \\ \text { IBGE } & \text { Instituto Brasileiro de Geografia e Estatística } \\ \text { ISO } & \text { International Organization for Standardization } \\ \text { LGPL } & \text { Lesser General Public License } \\ \text { MIDI } & \text { Musical Instrument Digital Interface } \\ \text { MIMB } & \text { Manual Internacional de Musicografia Braille } \\ \text { MIR } & \text { Music Information Retrieval } \\ \text { NIFF } & \text { Notation Interchange File Format } \\ \text { SEESP/MEC } & \text { Secretaria de Educação Especial/Ministério da Educação. } \\ \text { TTS } & \text { Text-to-Speech } \\ \text { XML } & \text { eXtensible Markup Language. } \\ \text { XSLT } & \text { eXtensible Stylesheet Language for Transformation. }\end{array}$




\section{Lista de Figuras}

2.1 Máquina Perkins, reglete e punção - ferramentas da escrita braille. . . . . . . . . . . 17

2.2 Numeração dos pontos em uma cela braille. . . . . . . . . . . . . . . . . . . 17

2.3 Alfabeto braille utilizado na língua portuguesa . . . . . . . . . . . . . . 18

2.4 Tabela 1-A do MIMB: notas musicais e pausas _ . . . . . . . . . . . . . . 20

2.5 Alterações . . . . . . . . . . . . . . . . . . . . . . . . . . . . . . . 21

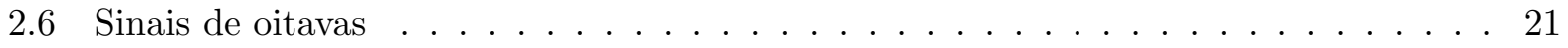

2.7 Representação em braille dos símbolos de clave . . . . . . . . . . . . . . . . . . 22

2.8 Representação em braille de um compasso. . . . . . . . . . . . . . . . . . . . . 22

2.9 Sinais de Intervalo . . . . . . . . . . . . . . . . . . . . . . . . . 23

2.10 Emprego do "Em Acorde" . . . . . . . . . . . . . . . . . . . . . . . . 23

2.11 Uso do sinal de ligadura para até quatro notas. . . . . . . . . . . . . . . . . 23

2.12 Duas opções de sinais para ligaduras envolvendo mais de quatro notas. . . . . . . . . 24

2.13 Exemplo de repetição parcial em braille . . . . . . . . . . . . . . . . . . . . 24

2.14 Tabela de símbolos para quiálteras . . . . . . . . . . . . . . . . . 25

2.15 Esquema dos principais indicadores de mudanças na musicografia braille . . . . . . 26

2.16 Linha vocal acompanhando linha melódica . . . . . . . . . . . . . . . 28

2.17 Leiaute no formato compasso sobre compasso . . . . . . . . . . . . . . . . . . . 29

2.18 Separação de compassos pelo ponto $3 \ldots \ldots$. . . . . . . . . . . . . 29

2.19 Método linha sobre linha: irregularidade no início dos compassos. . . . . . . . . . . 30

2.20 Método linha sobre linha: as linhas de um bloco podem ter tamanhos diferentes. . . 31

2.21 Método seção por seção . . . . . . . . . . . . . . . . . . . . . . . . . . 32

2.22 Método partitura vertical . . . . . . . . . . . . . . . . . . . 32

3.1 Diagrama da arquitetura Model-View-Controller (MVC) . . . . . . . . . . . . . . 41

3.2 Diagrama de estados - Relação entre os estados de navegação e as possíveis ações do usuário . . . . . . . . . . . . . . . . . . . . . . . . . 4 42

3.3 Representação do padrão arquitetural Hierarquical Model-View-Controller. . . . . . . 43

3.4 Componentes gráficos no Delius e sua organização hierárquica do HMVC . . . . . 44

3.5 Diagrama de classes mostrando como as classes de controle relacionam-se com as classes de visão e de modelo. . . . . . . . . . . . . . . . . . . . . . 49

3.6 Diagrama de classes mostrando a utilização dos componentes externos pelo Delius. . 50

4.1 Versão em tinta do arquivo MusicXML - helloworld.xml . . . . . . . . . . . . . . . 54

4.2 conteúdo do arquivo MusicXML - helloworld.xml . . . . . . . . . . . . . . 55

4.3 Exemplo de representação musical pelo formato BMML . . . . . . . . . . . . . 56 
4.4 Modelo de representação de Lassfolk . . . . . . . . . . . . . . . . . . . . 58

4.5 Comparação entre as variações partwise e timewise no formato MusicXML . . . . . . 59

4.6 Modelo de representação da estrutura de alto nível do formato BMML . . . . . . . . 59

4.7 Modelo de representação da estrutura de alto nível do Delius . . . . . . . . . . . . 60

4.8 Modelo de representação da estrutura de baixo nível do Delius . . . . . . . . . . . . 61

4.9 Modelo de representação completo . . . . . . . . . . . . . . . . . . . . 62

4.10 Etapas da tradução dos sinais braille para o modelo representativo. . . . . . . . . . . 64

4.11 Exemplo de árvore sintática criada pelo ANTLR . . . . . . . . . . . . . 65

4.12 Exemplos dos diagramas de Sintaxe gerados pelo ANTLR . . . . . . . . . . . . 65

4.13 Detalhes sobre a notação de quiálteras na grafia musical tradicional. . . . . . . . . 68

4.14 Comparação do emprego de tercinas nas grafias musicais. . . . . . . . . . . . . . . 69 


\section{Lista de Tabelas}

3.1 Teclas de acesso às funcionalidades do programa $\ldots \ldots \ldots$. . . . . . . . 38

3.2 Entradas e saídas e estado de implementação . . . . . . . . . . . . . . . . . 48

4.1 Tabela de softwares compatíveis com MusicXML . . . . . . . . . . . . . . 54

4.2 Representação da duração das notas . . . . . . . . . . . . . . . . . . . 67

5.1 Perfil dos entrevistados . . . . . . . . . . . . . . . . . . . 73

5.2 Conhecimento dos entrevistados em musicografia braille, musicografia em tinta e informática . . . . . . . . . . . . . . . . . . . . . 74

5.3 Tabela de frequências das respostas dos usuários . . . . . . . . . . . . . . 75

5.4 Tabela de frequências das respostas dos usuários . . . . . . . . . . . . . . . 76

5.5 Correlação de Spearman: Características dos usuários $\times$ respostas $\ldots$. . . . . . . 77

5.6 Respostas dissertativas dos usuários. (*) usuários cegos; $(* *)$ usuários com baixa visão. 79 


\section{Capítulo 1}

\section{Introdução}

Inclusão social é um tema que tem obtido destaque nos últimos anos. Não é só no Brasil que programas governamentais de fomento têm possibilitado o surgimento de entidades e fundações preocupadas com questões específicas relativas à adequação social de grupos com características especiais que demandam algum tipo de adaptação, cuidado ou assistência. E na medida em que o assunto é mais amplamente estudado, novos problemas são observados e novos estudos são exigidos nas mais diversas áreas do conhecimento humano. Mais que isso, raramente é possível falar sobre deficiência como um tema único e atômico; cada tipo de deficiência traz consigo problemas e desafios muito particulares.

Dentro desse leque amplo de necessidades especiais, a deficiência visual ocupa um espaço expressivo: no Brasil, segundo o censo realizado em 2010 pelo IBGE (2010), 23,9\% da população apresentava alguma deficiência de ordem visual, auditiva ou motora. Mais especificamente, 6.056.533 indivíduos ou $3,2 \%$ da população são portadores de baixa visão e 506.337 indivíduos $(0,3 \%$ da população) são $\operatorname{cegos}^{1}$. Para os educadores, de forma geral, o relacionamento com alunos deficientes ainda é pouco trivial. Diversos assuntos são de interesse dos profissionais da Educação como a questão do sucesso na alfabetização, do relacionamento do aluno cego com os outros alunos videntes $^{2}$, da necessidade ou não de adaptação das aulas, do preparo dos professores, da necessidade de algum acompanhamento paralelo especializado, dos motivos de evasão de cursos e muitos outros.

Por outro lado, o sucesso profissional e financeiro é outro ponto de interesse, por sua vez fortemente dependente do progresso nas questões relativas à educação. Em teoria, há suficiente respaldo legal para que o deficiente ingresse no mercado de trabalho devidamente qualificado: o artigo 60, parágrafo único, da Lei de Diretrizes e Bases (LDB) obriga o poder público a ampliar o atendimento aos alunos com necessidades especiais na rede pública regular de ensino (de Souza, 2010). Além disso, versa o artigo 93 da lei 8.213/91 sobre a obrigatoriedade de contratação de beneficiários reabilitados ou pessoas portadoras de deficiência, na quantidade mínima de 2 a $5 \%$, para empresas com 100 ou mais empregados (de Previdência Social, 1991).

O presente trabalho parte de duas premissas fundamentais: a primeira, de que a Música é uma área do conhecimento onde há espaço para a atuação de deficientes visuais; a segunda, de que o ensino superior é importante na construção do caráter e na profissionalização do indivíduo, inclusive relacionando-o, perante à sociedade, à sua área de conhecimento. O escopo principal deste trabalho, portanto, está na questão da inserção do indivíduo cego no ambiente de ensino superior de música. Muito embora o trabalho realizado por entidades assistenciais sejam fundamentais no processo de musicalização com foco nas necessidades especiais, para o aprendizado da teoria, da prática e da

\footnotetext{
${ }^{1}$ Além destes números, a pesquisa ainda cita 35.774 .392 pessoas que declararam ter dificuldade para enxergar, mesmo com o uso de óculos ou lentes de contato, o que equivale a $18,8 \%$.

${ }^{2} \mathrm{O}$ termo "vidente" é comumente utilizado, dentro da literatura específica, para referir-se ao indivíduo que não é cego.
} 
musicografia braille ${ }^{3}$ (o método de leitura e escrita musical baseada no código braille), o ensino superior modela-se, via de regra, como um ambiente misto onde a grande maioria é formada por pessoas videntes e onde o próprio ambiente na maioria das vezes está constituído considerando que a capacidade de ver é quase tão fundamental quanto a capacidade de ouvir.

Com base nos problemas pertinentes à inclusão de deficientes visuais no ensino superior de música, esta dissertação abordará as possibilidades de uso de tecnologias assistivas como ferramentas para a superação de obstáculos, sobretudo o hiato criado pelos diferentes sistemas de grafias utilizados por cegos e videntes, uma questão de extrema relevância em ambientes onde espera-se haver espaço para todas as pessoas, independentemente da presença ou ausência de deficiências. Mais especificamente, o cenário onde este trabalho procurará dar maior atenção é o do relacionamento entre alunos cegos e professores videntes, considerando o provimento adequado de material de apoio aos estudos, a preparação de provas e exercícios e a correção dos mesmos buscando avaliar adequadamente o desempenho do aluno.

Como contribuição, este trabalho procurará:

- sistematizar as diferenças entre a grafia musical convencional da música ocidental para escrita em tinta ${ }^{4}$ e a musicografia braille, desenvolvida para permitir a leitura de música por meio não visual, mas tátil.

- investigar dispositivos tecnológicos existentes que voltem-se ou aproximem-se do tema central deste trabalho.

- estudar a possibilidade de se obter partituras musicais gráficas produzidas por uma pessoa cega fazendo uso da musicografia braille, na intenção de melhorar a comunicação entre um professor de música vidente que recebe em sua sala um aluno deficiente visual, situação na qual ambos provavelmente utilizam diferentes grafias musicais.

- desenvolver um aplicativo de notação musical, devidamente adaptado às condições especiais de seus possíveis usuários, que utilize a musicografia braille como método de entrada de informação e que permita conversão do material produzido para partituras gráficas convencionais.

- manter o desenvolvimento deste aplicativo sob a filosofia de software livre, permitindo o envolvimento da comunidade no aprimoramento do mesmo.

\subsection{Motivação e histórico}

O trabalho apresentado é resultado da vivência do autor com deficientes visuais ligados à música desde o final da década de 90. De 2000 até 2008 esta experiência foi intensificada enquanto o autor, graduando-se pelo Departamente de Música da Escola de Comunicação e Artes (CMU/ECA) da USP, teve contato com colegas cegos e pôde perceber dificuldades tanto na adequação destes alunos ao formato das aulas como também na adaptação dos professores às necessidades especiais envolvidas, sobretudo na dificuldade em se prover material didático adaptado à deficiência, ou seja, em braille. Percebeu-se que estas dificuldades poderiam potencialmente resultar na desistência dos alunos cegos. Iniciou-se então, no Departamento, uma mobilização em torno do problema, e o levantamento de soluções capazes de proporcionar a integração necessária. Interessado no provimento de material de apoio em versão braille para as aulas, inicialmente partituras para a prática de canto coral (disciplina obrigatória por vários anos em todos os cursos do departamento) e outras

\footnotetext{
${ }^{3}$ A Comissão Brasileira do Braille (CBB) recomendou a grafia braille, com "b" minúsculo e "ll", respeitando a forma original francesa, internacionalmente empregada (SEE/ME, 2002). Porém, quando se referir ao educador Louis Braille e quando o sobrenome Braille fizer parte do nome de instituições, grafa-se Braille.

${ }^{4}$ É comum entre as pessoas que lidam com estas diferentes grafias tratá-las por "em braille" e "em tinta", esta última referindo-se à escrita (literária ou musical) de caráter gráfico, visual.
} 
disciplinas como Piano, Análise Musical, Harmonia e Contraponto, o autor envolveu-se no processo de levantamento e aquisição de softwares auxiliares e até mesmo na formação de uma equipe de apoio para as demandas de conversão, uso da impressora braille e outros.

Naquele momento o departamento contava com apenas um aluno deficiente visual; até a conclusão do curso pelo mesmo é possível afirmar que muito pouco resultado foi obtido. Era visível, no entanto, que com algumas mudanças nos processos e com suficiente respaldo tecnológico seria possível reverter essa situação. Além disso esse problema de modo algum é específico desta unidade, sendo enfrentado por outras instituições semelhantes. A experiência vivenciada no CMU serviu portanto como motivador para a busca de soluções que garantam, futuramente, respaldar os alunos deficientes visuais.

Foi neste cenário onde o autor teve então contato com a musicografia braille e iniciou um processo de investigação a respeito das possibilidades de transcrição por meios automatizados, considerando que o trabalho de transcrição por meio humano seria inviável, tanto por falta de gente capacitada como pelo trabalho excessivo que essa tarefa demandaria. A primeira abordagem foi na verdade a composição de um processo estruturado, criando uma fila de prioridade de materiais que deveriam ser transcritos para braille e a composição de um acervo que permitisse reuso - no canto coral, por exemplo, é natural refazer certas peças do repertório em anos seguintes, e tais obras teriam alguma prioridade de transcrição.

O primeiro trabalho realizado nessa direção foi o desenvolvimento de um aplicativo que fosse disponível via internet, de arquitetura cliente-servidor, com o objetivo de compôr um acervo de partituras digitais e transcrevê-las para braille, atendendo às regras descritas no Manual Internacional de Musicografia Braille (União Mundial dos Cegos, 2004). Este aplicativo foi chamado de Delius, em homenagem ao compositor inglês Frederick Delius (1862-1934) que, por conta de uma doença, acabou perdendo a visão. Nesta ocasião, o aplicativo ainda era pouco versátil, bastante específico para a transcrição mais essencial (notas e pausas, para melodias simples). A intenção era dar resposta rápida à necessidade de prover tais materiais, integrando-a ao processo criado, de modo que bolsistas ou estagiários seriam incumbidos de digitalizar as partituras utilizando ferramentas de notação musical comuns (como o Finale ${ }^{5}$ ou Sibelius ${ }^{6}$ ), de acordo com a fila de prioridade, e então armazenando-as no acervo digital do Delius, onde obteriam uma cópia transcrita do material original em um formato compatível com uma impressora braille, onde seria finalmente produzido o resultado desejado.

Embora promissor, o desenvolvimento não foi concluído em tempo de realmente poder ser avaliado quanto à sua eficácia no processo; o aluno em questão, peça essencial dessa cena, estava já prestes a se formar e muito da mobilização de pessoas e recursos já demonstrava indícios de dispersão. Seria então esse o momento de aprofundar-se na literatura relativa ao assunto e analisar a questão de forma mais panorâmica. Desde então pôde-se verificar algumas pesquisas movimentandose nessa mesma direção (Goto et al., 2007), o que não só legitimam a necessidade como também propõem possíveis caminhos e soluções os quais este trabalho também procurará investigar.

\subsection{Inclusão do deficiente visual no ensino superior}

O Artigo 208 da Constituição Federal discursa sobre o cumprimento do dever do Estado com relação à educação, garantindo "atendimento educacional especializado aos portadores de deficiência, preferencialmente na rede regular de ensino", e ainda "acesso aos níveis mais elevados do ensino, da pesquisa e da criação artística, segundo a capacidade de cada um". A garantia de condições

\footnotetext{
${ }^{5}$ http://www.finalemusic.com

${ }^{6} \mathrm{http}: / /$ www.sibelius.com
} 
para o ingresso e sucesso do deficiente no ensino superior não seria, certamente, uma preocupação observada apenas na constituição brasileira; tampouco pode-se afirmar que essa preocupação é recente, dado que a última constituição é de 1988. Na prática, porém, poucas instituições de ensino, sobretudo do ensino superior, se mostram satisfatoriamente adequadas para receber estudantes deficientes, e os motivos são muitos. Inicialmente é fundamental perceber que, para que o índice de ingresso de deficientes no ensino superior acompanhe percentualmente a população real de deficientes, é necessário que o estudante candidato à vaga na instituição de ensino superior esteja tão bem preparado quanto um estudante vidente, o que também não é uma verdade até então: muitos cegos ainda saem do ensino médio analfabetos em braille justamente pela falta de material de apoio durante o período escolar.

As questões envolvidas na dificuldade de ingresso de deficientes no ensino superior não serão investigadas por este trabalho, que se deterá na hipótese do aluno ingressante de fato, supostamente avaliado como tendo iguais condições de preparo para acompanhamento do curso com relação aos outros ingressantes. Ademais, o trabalho concentrará a atenção no aluno ingressante em um curso de Música, dadas as especificidades da musicografia braille que são de interesse particular desta pesquisa.

\subsection{Conceitos fundamentais e desafios}

\section{Desenho Universal}

Desenho Universal é um conceito que gradativamente vem permeando a sociedade e seu modo de vida, influenciando-a e resultando em mudanças facilmente observáveis seja na construção civil, arquitetura, informática, literatura e telecomunicações, entre muitas outras áreas do conhecimento. Trata-se da preocupação com que o projeto de um produto ou ambiente garanta que o mesmo possa, na medida do possível, ser utilizável por qualquer indivíduo sem a necessidade de adaptação ou redesenho por conta de quaisquer limitações, deficiências ou necessidades especiais. Deseja-se também que tais designs sejam simples e que acrescentem o mínimo possível de custo de produção com relação a um design convencional; o sucesso na implementação de um produto acessível depende da relação custo-benefício apresentada. O conceito é regido por uma série de princípios que devem ser observados durante a concepção de um produto ou projeto, como modo de operação simples, flexível e intuitivo, tolerância a erro, uso confortável e pouco esforço físico envolvido (Center for Universal Design, 2006).

Este conceito relaciona-se integralmente com o presente trabalho; a intenção não é simplesmente criar adaptações entre grafias, mas também investigar em quais momentos a musicografia é por si indepentente da sua forma de grafia. O Desenho Universal será, portanto, um agente para nortear decisões sobre a adoção de métodos e procedimentos de análise e implementação.

\section{O código braille e as novas tecnologias}

A questão do futuro do código braille vem sendo bastante discutida entre educadores, sociólogos e bibliotecários. O advento de novas tecnologias tem dado margem a uma série de proposições de alternativas para o braille, fazendo para tanto o uso de uma série de alegações a respeito da legibilidade e praticidade do código e apontando dados que demonstram que na medida em que o tempo passa menos cegos são alfabetizados em braille, embora cada vez mais estes indivíduos ocupem espaço no mercado de trabalho (Belarmino, 2001). Isso tem sido motivo para que pessoas ligadas ao assunto se dividam em dois grupos bastante extremos; enquanto alguns afirmam que o braille está condenado ao desuso, outros assumem uma postura rígida em defesa do braille e de sua 
prosperidade.

Outro ponto relevante também é que essas novas formas de leitura e escrita geralmente estão relacionadas a arquivos digitais. Por conta de problemas, como a facilidades de proliferação de material digital, adicionados á falta de dispositivos legais que regulamentem satisfatoriamente a composição de livros e outros registros em formatos digitais, há ainda o problema de que o acervo acessível para deficientes visuais em uma biblioteca ainda está restrito ao material fisicamente impresso em braille.

Este fato se relaciona com o presente trabalho em um ponto não muito intuitivo: a relação entre o código braille e a música ainda é muito forte. Embora seja natural que a necessidade de leitura e escrita para fins literários seja expressivamente maior do que a leitura ou escrita musical em braille, atualmente há suficiente respaldo tecnológico para atender a primeira finalidade, o suficiente inclusive para que muitos cegos não sejam alfabetizados em braille por não sentirem necessidade, havendo um computador que possa suprir esta necessidade através de softwares de leitura automática. No caso da música, este quadro é diferente: o estudo formal de música, ainda não tão substituído por subterfúgios de ordem tecnológica, atualmente utiliza o código braille como principal método de comunicação escrita ${ }^{7}$.

\section{Perfis do estudante deficiente visual}

Através de experiências colhidas por três anos ministrando um curso de Musicografia Braille, de Souza (2009) retrata diferenças bastante expressivas no processo de aprendizado relacionadas ao tipo de deficiência visual. Em primeiro lugar, é fundamental distinguir cegueira adquirida e cegueira congênita, uma vez que a dificuldade em se realizar a leitura pelo toque do dedo é maior quando o indivíduo inicia este aprendizado em idade avançada, sobretudo quando já tem uma referência visual ou mesmo já foi alfabetizado em tinta. De fato, qualquer pequeno período de uso efetivo do aparato sensorial visual é suficiente para modificar toda a concepção de mundo do indivíduo e consequentemente seus processos cognitivos. Nestes grupos, considerando os que já tiveram e os que nunca tiveram experiências visuais, podem ser verificadas diferentes necessidades em todos os processos de aprendizagem.

Além disso, a graduação da cegueira é outro fator que deve ser levado em consideração; tratandose de visão subnormal, dependendo do grau de acuidade, o aluno pode enfrentar situações bastante ímpares, como por exemplo ter capacidade de ler uma partitura musical utilizando lentes amplificadoras poderosas, mas enfrentar uma dificuldade muito grande em escrever notas em um pentagrama, a ponto de preferir, para tanto, fazer uso da musicografia braille.

\section{Avaliação de desempenho dos alunos}

A Secretaria de Educação Especial do Ministério da Cultura (SEESP/MEC) possui uma série de publicações com recomendações para atendimento educacional especializado. Na publicação que trata de deficiência visual (SEE/SE, 2007) encontramos o seguinte excerto falando sobre avaliação:

Alguns procedimentos e instrumentos de avaliação baseados em referências visuais devem ser alterados ou adaptados por meio de representações e relevo. É o caso, por exemplo, de desenhos, gráficos, diagramas, gravuras e do uso de microscópios.

\footnotetext{
${ }^{7} \mathrm{O}$ autor chegou a ouvir alguns comentários informais de que a Musicografia Braille poderia inclusive estar "salvando" o braille, já que para o fim específico seu uso ainda é fundamental, diferentemente do braille literário, que tem perdido espaço para programas de processamento de texto acessíveis.
} 
Em algumas circunstâncias é recomendável valer-se de exercícios orais. A adaptação e produção de material, a transcrição de provas, exercícios e de textos em geral para o sistema braille podem ser realizadas em salas multimeios, núcleos, serviços ou centros de apoio pedagógico. Se não houver ninguém na escola que domine o sistema braille, será igualmente necessário fazer a conversão da escrita braille para a escrita em tinta.

Convém observar a necessidade de estender o tempo da avaliação, considerando-se as peculiaridades já mencionadas em relação à percepção não visual. Os alunos podem realizar trabalhos e tarefas escolares utilizando a máquina de escrever em braille ou o computador, sempre que possível.

\section{Acervos e reaproveitamento de material em Braille}

Um dos grandes problemas da conversão entre tinta e braille é justamente o tempo desprendido entre as tarefas de digitalização e correção, quando estas se fazem necessárias. Bonilha $(2005,2010)$ cita constantemente a importância da composição de um acervo destes materiais, uma vez que o processo é otimizado na medida em que se evita que este trabalho de digitalização seja feito mais de uma vez.

O compartilhamento dessa informação, porém, ainda é algo que requer um cuidado especial, por poder infringir leis de proteção de direitos autorais. Além do mais, depende de uma estrutura organizacional consistente que integre diversas bibliotecas e centros de acessibilidade. Essa questão é tangente ao trabalho aqui apresentado, mas por demandar uma investigação totalmente dirigida e bastante extensa, não fará parte do escopo deste trabalho.

\subsection{Utilização de computadores por deficientes visuais}

A evolução dos computadores pessoais e de seus recursos multimídia, somada ao advento e popularização da internet, tem protagonizado uma incrível melhoria do acesso à informação por deficientes visuais. Através de dispositivos de adaptação, um usuário é capaz de, sem fazer uso da visão, utilizar um computador para buscar e receber informação, desde que esta esteja disponível obedecendo a algumas diretrizes de acessibilidade. Auxiliados por programas leitores de tela, os usuários podem receber a informação produzida para a tela do computador; estes programas interpretam o conteúdo textual dos componentes gráficos e, mediante heurísticas próprias, produzem um resultado sonoro, utilizando recursos de síntese de voz (TTS). É possível encontrar uma variedade de leitores de tela, que variam muito em custo, suporte a sistemas operacionais, métodos de síntese de voz e outros recursos próprios.

É bastante comum que um usuário de leitores de tela tenha mais de um programa para esta finalidade instalado em seu computador, e que alterne entre eles, buscando o que é mais adequado para trabalhar em conjunto com cada programa. Estudos (Clóvis et al., 2007; Núcleo de Acessibilidade Virtual do IF 2009) demonstram também a discrepância na interpretação feita por diversos programas de leitura de tela para determinados programas de uso comum, bem como diferenças nos perfis dos usuários quanto às suas preferências de programas para leitura de telas. Em contrapartida, nem todos os usuários utilizam mais de um leitor de tela, por conta de dificuldades de adaptação, o que pode restringir o usuário ao uso de sistemas operacionais que suportem o programa de leitura de tela ao qual o usuário sente-se adaptado.

Para que a informação seja acessível por usuários deficientes visuais, é necessário portanto que certos pontos sejam observados durante o processo de desenvolvimento dos aplicativos. Por exemplo, a interpretação sonora das telas só é possível para conteúdo produzido em texto. Ou seja, textos contidos em imagens e fotografias não são lidos. 
Há também questões idiomáticas. Algoritmos de síntese de voz têm forte dependência fonética e, como consequência, geralmente são encontradas vozes individuais para cada idioma. Com isso, os leitores de tela apresentam resultados insatisfatórios ao lerem conteúdo em idiomas para os quais não estão devidamente preparados ou configurados.

Além da interação por meio de respostas sonoras, outro ponto importante da relação entre deficientes visuais e computadores é a impossibilidade de uso de certos dispositivos de entrada, como o mouse. Por esse motivo, o deficiente visual deve ser capaz de acessar todos os recursos e atalhos por meio do teclado.

Considerando estes fatores de navegação por teclado e a necessidade da audição dos atalhos e opções, a utilização de programas de computador por deficientes visuais também é consideravelmente mais lenta do que por pessoas com visão normal. Ainda assim, o acesso à informação assistido por computador, seja pela navegação na internet ou pela leitura de um livro eletrônico, é beneficiado por recursos como o de busca por conteúdo e de sistematização da leitura.

Para que tais necessidades sejam atendidas, algumas entidades são responsáveis por criar recomendações e padrões que possam nortear o desenvolvimento de programas e de conteúdo de forma acessível. A Web Accessibility Initiative (WAI) ${ }^{8}$ traz uma série de recomendações para que o conteúdo eletrônico para internet seja preparado de forma a garantir acessibilidade, não apenas para questões relativas à deficiência visual. O governo norte americano criou a Section 508 of the Rehabilitation $A c t^{9}$, uma lei com diretrizes oficiais para acessibilidade eletrônica, de forma ampla; embora seja uma questão regional, estas diretrizes inspiram diversas auditorias e certificações em qualidade de software.

\subsection{Grupos de pesquisa e trabalho relacionados}

O presente trabalho trata de um assunto bastante específico e ainda bastante carente de trabalhos e publicações. Por outro lado, percebeu-se que existem entidades e profissionais que relacionamse diretamente com o assunto de forma prática. Estas entidades e profissinais foram fundamentais para esta pesquisa por diversos motivos, mas principalmente por propiciarem uma imersão real dentro do contexto e garantindo assim um conhecimento de causa mais amplo do que o que seria possível apenas pela literatura relacionada ao tema. As principais instituições e grupos de pesquisa serão aqui mencionados, na intenção de prover um possível ponto de partida para outros futuros trabalhos sobre o tema.

\section{Laboratório de Acessibilidade da Unicamp}

Oficialmente inaugurado em dezembro de 2002, o Laboratório de Acessibilidade (LAB) da Biblioteca Central da Universidade Estadual de Campinas ${ }^{10}$ tornou-se um espaço de convergência de diversos trabalhos relacionados aos temas de inclusão e acessibilidade, e serve de recurso para a universidade no provimento de acesso à informação adaptado, além de ter se especializado no preparo de material didático em braille. Para esta função, o LAB não só reúne uma quantidade expressiva de aplicativos específicos para estes fins como também pessoas com conhecimento de manuseio. Além disso, no LAB o autor teve a oportunidade de fazer contato com usuários finais dos serviços prestados pela instituição, deficientes visuais com conhecimento em música e musicografia braille. Através destes encontros foi possível analisar as tecnologias assistivas atualmente em

\footnotetext{
${ }^{8}$ http://www.w3.org/WAI/

${ }^{9} \mathrm{http}: / /$ www.access-board.gov/508.htm

${ }^{10}$ http://www.todosnos.unicamp.br:8080/lab/
} 
uso, os procedimentos de uso das mesmas e a qualidade do produto final.

\section{Rede Saci}

A Rede Saci (http://saci.org.br) é uma entidade que visa estimular a inclusão social e digital, disponibilizando de várias maneiras informação sobre deficiência. É uma realização da Coordenadoria Executiva de Cooperação Universitária e de Atividades Especiais da Universidade de São Paulo (CECAE-USP), da Rede Nacional de Ensino e Pesquisa (RNP), do Amankay Instituto de Estudos e Pesquisa, e do Núcleo de Computação Eletrônica da Universidade Federal do Rio de Janeiro (NCE-UFRJ). A rede Saci acompanhou este trabalho desde o início com alguma proximidade, além de fornecer apoio para testes de impressão em braille.

\section{Instituto Padre Chico}

O Instituto Padre Chico (http://www.padrechico.org.br) é uma entidade de auxílio aos cegos, atuante há mais de 80 anos. Durante a pesquisa, o autor tomou conhecimento do curso de musicografia braille ministrado neste instituto, onde obteve como colaboração diversas sugestões de melhorias desejáveis no Delius.

\section{Conservatório Municipal de Guarulhos}

No Conservatório de Guarulhos ${ }^{11}$ é ministrado um curso de musicografia braille que visa auxiliar alunos deficientes em formação no conservatório. Atualmente são três turmas de alunos semanais, sendo que o conservatório já formou mais de 70 pessoas com deficiência desde o início do projeto de inclusão em 2005, projeto este que também conta com cursos para deficientes auditivos. Esta instituição possibilitou ampliar o relacionamento com pessoas com conhecimentos em musicografia braille, cuja participação de grande importância para a realização de testes do programa, apontamento de defeitos e sugestões de melhorias.

\section{Grupo de discussões}

No início de 2011 foi criado pelo autor um grupo de discussões ${ }^{12}$ sobre musicografia braille com foco em tecnologia. É um grupo aberto publicamente para leitura e permite inscrição de novos membros. Desde a criação deste grupo, muitos dos contatos efetuados no período, com professores e estudantes de musicografia braille, são hoje participantes. Tem sido um meio bastante útil para se receber sugestões de melhorias para o Delius, anunciar novos releases, agendar encontros e também divulgar outros projetos e listas dentro do mesmo tema.

\subsection{Processos e ferramentas para conversão entre partituras em tinta e braille}

Converter partituras para braille é uma demanda importante do LAB. Com a presença de dois alunos de pós-graduação do Instituto de Artes (IA), o laboratório recebe frequentes solicitações de conversão de partituras para braille. Um bolsista do SAE (Serviço de Apoio ao Estudante, da

\footnotetext{
${ }^{11}$ http://www.guarulhos.sp.gov.br, havendo acesso por dentro do portal (sem referência direta).

${ }^{12}$ https://groups.google.com/d/forum/musicografia-braille
} 
UNICAMP), vidente, digitaliza a obra solicitada através do software Finale. Dois softwares desenvolvidos pela empresa italiana Veia Progetti ${ }^{13}$ são então utilizados: o primeiro é um plug-in para o Finale que converte o conteúdo do arquivo para braille em um formato que é lido pelo segundo programa, o Braille Music Editor (BME), onde se efetua a revisão e correção, em braille, do conteúdo musical.

Este processo envolve necessariamente conhecimentos em musicografia braille e grafia musical em tinta, de forma que, a menos no caso de uma pessoa com ambos os conhecimentos específicos participe do processo, duas pessoas serão utilizadas para a realização da conversão. Os aplicativos Braille Music Editor e Finale não são gratuitos, embora o plug-in de conversão seja disponibilizado livremente pelo próprio fabricante. O processo depende de conhecimento de uso específico do Finale, embora exista no mercado uma grande variedade de programas para notação musical.

Segundo Bonilha (2006), o Braille Music Editor permite que documentos musicais sejam criados recebendo a entrada em braille, utilizando o próprio teclado do computador e com uma boa assistência às regras da musicografia braille estabelecidas no Manual Internacional de Musicografia Braille (MIMB). A autora cita como desvantagem de uso o fato de que o conteúdo produzido em braille no BME somente é reconhecido em linguagem musical após um comando de processamento; quando ocorre erro neste processamento, o usuário enfrenta problemas de leitura do conteúdo musical.

Outros apontamentos a respeito do BME é que não há visualização, no programa, da partitura gráfica resultante do processamento deste material em braille. Embora o BME seja bastante adequado para assistir à produção de uma partitura final em braille, recursos ainda são necessários para que a ferramenta possa trabalhar como agente auxiliador na comunicação entre cegos e videntes.

Outra forma de realizar essa conversão é utilizando uma suíte de aplicativos da empresa Dancing Dots ${ }^{14}$. Esta suíte é composta de um aplicativo para OCR chamado SharpEye, responsável por digitalizar o conteúdo de uma partitura impressa e transformá-lo em MIDI ou NIFF, seguido de um outro aplicativo chamado Lime que permite editar e corrigir erros da digitalização para depois enviar o material editado para o aplicativo Goodfeel, responsável por finalmente converter o produto final para braille. Este pacote de aplicativos não só é pago como é caro ${ }^{15}$. O programa de OCR tem um índice baixo de acerto, exigindo muita correção manual, tornando o procedimento pouco eficaz (Bonilha, 2006). Esta suíte de programas da Dancing Dots, bem como o BME, funcionam apenas em sistema operacional Windows.

Como trabalho de conclusão de curso de graduação o autor deste trabalho desenvolveu o $D e$ lius, um aplicativo de conversão de partituras do formato MusicXML ${ }^{16}$ para uma versão adequada para impressão em braille. Pouco tempo depois outros trabalhos (Goto et al., 2007; Inthasara et al., 2007) foram publicados na mesma direção. No laboratório Gotoh, na Universidade Nacional de Yokohama, foi lançado o BrailleMUSE, um aplicativo também de arquitetura cliente-servidor, que recebe como entrada um arquivo no formato MusicXML e devolve ao usuário um arquivo texto com o conteúdo em braille pronto para impressão. De acordo com Goto et al. (2007), o programa atende parcialmente às regras do MIMB. O laboratório Gotoh possui parceria com uma equipe de voluntários que utilizam o recurso para facilitar o processo de transcrição, reduzindo a mão-de-obra apenas à tarefa de correção.

\footnotetext{
${ }^{13}$ http://www.veia.it/en

${ }^{14}$ http://www.dancingdots.com

${ }^{15}$ US $\$ 1395,00$ o valor da suíte de programas da Dancing Dots, em junho de 2010, de acordo com a página do próprio desenvolvedor.

${ }^{16}$ MusicXML é um formato criado pela Recordare LCC para troca de informações musicais entre aplicativos. Será tratado em detalhes no próximo capítulo.
} 
O BrailleMUSE oferece um suporte bastante satisfatório às regras de musicografia braille, além de permitir alguma personalização, para quando existem múltiplas possibilidades de grafia ou diagramação. Em contrapartida, o Delius integra o serviço de transcrição a um banco de dados, de forma que o material a ser convertido deve primeiro ser armazenado no serviço e ficará disponível em acervo juntamente com sua cópia convertida em braille, na intenção de prover reaproveitamento da informação ${ }^{17}$. Além disso, o Delius fornece uma forma de visualização do conteúdo em braille em HTML, útil para pessoas videntes poderem conferir o conteúdo a ser impresso em braille.

O processo de converter partituras originalmente em braille para tinta (processo portanto inverso ao apresentado anterior) é ainda mais carente de assistência tecnológica. O BME é o único aplicativo instalado no LAB com capacidade de receber entrada em braille. Ele é capaz de produzir três formatos de arquivo diferente: o arquivo PLY, extensão própria do programa, arquivo texto (TXT) adequado para impressão em braille e arquivo MIDI, adequado para execução e capaz de ser lido/interpretado por outros aplicativos. O arquivo MIDI, entretanto, não é um formato capaz de representar todos os elementos musicais. No estudo das ferramentas do LAB realizado por Bonilha (2005), a autora cita que este processo causa perda de informações importantes, como por exemplo a armadura de clave, ligaduras de frase, textos, etc. Além disso, a autora também aponta que o Braille Music Editor, apesar de seguir as principais normas do MIMB, não consegue reconhecer alguns símbolos, como o segno, utilizado para retorno em um trecho musical anterior, e também as indicações que se denominam musicalmente por "casa 1" e "casa 2".

O Conservatório de Guarulhos utiliza nas classes de musicografia braille o software MusiBraille $^{18}$, projeto desenvolvido pelo Núcleo de Computação Eletrônica da UFRJ. Este programa tem sido bastante difundido e utilizado para musicalização e ensino da musicografia braille. Além da visualização em braille, o programa possui um pentagrama gráfico que mostra os símbolos musicais criados, com certas limitações. O programa não oferece suporte a partituras com mais de um instrumento, além de comtemplar um conjunto de regras bastante limitado do MIMB. O Musibraille integra consigo um leitor de tela, não dependendo de programas de leitura de tela de terceiros isso é vantagem em certos aspectos, mas a comunicação com os leitores terceiros, geralmente já utilizados pelos usuários, promove uma experiência de uso mais homogênea com os outros recursos utilizados pelo usuário em seu computador. Outras limitações percebidas são a ausência de suporte multi-idioma e a dependência do sistema operacional Windows para sua execução. Segundo informações no site do mantenedor ${ }^{19}$, o programa é distribuído sob licença LGPL, embora não haja nenhuma referência para download do código-fonte.

No Instituto Padre Chico há também uma demanda de confecção de partituras em braille para material didático das aulas de musicografia braille. Neste cenário, o computador também é utilizado, embora não sejam utilizados programas próprios para música; utiliza-se o WinBraille, um programa desenvolvido pela Index Braille ${ }^{20}$, também fabricante de impressoras braille. Este programa tem como finalidade justamente receber entradas em braille e efetuar o gerenciamento da impressão. É válido mencionar que a empresa desenvolvedora já não mais oferece suporte ao aplicativo.

\footnotetext{
${ }^{17}$ Por questões legais, o sistema permite que o usuário defina o acesso aos arquivos como público ou apenas para usuários de determinados grupos.

${ }^{18}$ http://intervox.nce.ufrj.br/musibraille

${ }^{19}$ Informações encontradas na página http://www.musibraille.com.br/download.htm, em 07/2012

${ }^{20}$ http://www.indexbraille.com
} 


\subsection{Delius: um aplicativo de notação musical em braille}

$\mathrm{Na}$ intenção de prover assistência ao aluno deficiente visual, particularmente o ingressante em curso superior de música, o presente trabalho discorrerá sobre o desenvolvimento de um software para notação musical que utilize como método de entrada a musicografia braille, que possa ser utilizado para assistir à produção de conteúdo musical em braille, produzir saídas para impressão em braille e também converter este resultado para partituras tradicionais, em tinta. Estas saídas em tinta serão produzidas em um formato de arquivo que possa ser lido por outros programas que permitam sua edição e impressão adequada. O resultado do desenvolvimento está publicado e acessível pelo endereço http://sourceforge.net/projects/delius/, contendo os arquivos para instalação e código fonte.

Evidentemente, outros recursos são necessários para satisfazer a necessidade por trás deste desenvolvimento - não apenas na área de tecnologia assistiva, mas também na melhoria de processos, leis de incentivo e até mesmo esclarecimento social. Este trabalho, no entanto, focará no escopo acima apresentado, considerando que outras pesquisas avançam na solução de outras facetas deste problema. O produto desta pesquisa foi chamado de Delius, herdando o nome do trabalho que fora desenvolvido no passado (conforme mencionado na seção 1.1), e que atuava no processo inverso de conversão entre braille e tinta.

\section{Objetivos}

Conforme mencionado acima, o objetivo do aplicativo é receber do usuário informação musical em braille e convertê-la em um arquivo que possa ser lido por editores de partitura em tinta. Para tanto, será utilizado como formato de saída principal o MusicXML, cujo uso será devidamente justificado na seção 4.1. O aplicativo deve buscar uma comunicação eficaz com os programas leitores de tela, informando o usuário sobre suas ações e sua posição no documento que está sendo produzido. O resultado gráfico exibido no monitor não deve ser de conhecimento obrigatório para o usuário, uma vez que espera-se que o usuário possa usar o aplicativo mesmo que não possa fazer uso do sentido da visão. Ao mesmo tempo, é fundamental que toda a informação musical produzida possa ser representada graficamente, por dois motivos: em primeiro lugar, é esperado que o programa seja também utilizado por pessoas videntes, caso de muitos professores de musicografia braille por exemplo; em segundo lugar, há o desejo de promover a interação entre cegos e videntes em um mesmo ambiente, tornando-se com isso um potencial auxiliador no relacionamento entre professores videntes e alunos cegos, cenário comum no ambiente de ensino superior de música, conforme já mencionado na introdução.

O aplicativo deverá garantir uma saída para impressão em braille e a persistência do material editado para futuras reedições. Espera-se que seja possível, ainda que futuramente, que o aplicativo possa receber arquivos em formato MusicXML também como entrada, convertendo-os para braille, unificando em si os dois caminhos do processo de conversão.

Outro motivo importante deste desenvolvimento é a busca pela simplificação do processo de transcrição de partituras como um todo. Atualmente, este processo depende geralmente da utilização de mais de um software para que os resultados sejam alcançados. O aplicativo então deve ser desenhado para que, ainda que a primeira versão tenha limitações de funcionalidades, seja possível futuramente agregar recursos suficientes para se compor uma suíte de funcionalidades que possa abranger todas as variações dos processos de conversão entre braille e tinta, dando margem para que outras possibilidades que não são tratadas nesse momento (receber entrada por scanner, por exemplo) sejam também implementáveis. 


\subsection{Princípios relacionados ao desenvolvimento do Delius}

\section{Conformidade com o conceito de Desenho Universal}

Também é objetivo deste aplicativo demonstrar conformidade com o conceito de Desenho Universal, mencionado na seção 1.3. Os princípios fundamentais deste conceito - igualdade, adaptabilidade, intuitividade, tolerância a erro e baixo esforço - serão interpretados, no que diz respeito ao desenvolvimento deste aplicativo, conforme os tópicos abaixo:

- Igualdade: O aplicativo deve poder ser operado por pessoas com diferentes capacidades, com adaptação nos pontos onde se faça necessário, mas garantindo um ambiente único.

- Adaptabilidade: O aplicativo deve ser expansível de forma a futuramente atender pontos ausentes no escopo inicial.

- Intuitividade no uso, buscando que o usuário sem experiência de uso consiga melhorar sua capacidade de operar o aplicativo interagindo com o mesmo.

- Tolerância a erro: O aplicativo deve permitir que erros do usuário não comprometam sua produção; Para tanto, uma série de medidas devem ser consideradas, como a possibilidade de desfazer operações (Undo) e também fornecer um retorno detalhando os possíveis erros, permitindo que sejam feitas as devidas correções.

- Baixo esforço: facilitar o acesso às funções, buscando conforto e ergonomia; cuidar para que pessoas com dificuldades motoras não tenham dificuldades em operar o programa.

\section{Código aberto}

Inicialmente, o desenvolvimento deste aplicativo se justifica pela própria disponibilização gratuita do produto final e pelas capacidades de expansão do mesmo pela comunidade de código aberto, livre de dependência de um pequeno grupo de pessoas ou entidades. Atualmente, a conversão de partituras assistida por computador é baseada em suítes de aplicativos comerciais cujas licenças nem sempre são baratas, podendo estar além das possibilidades financeiras de muitos usuários. Além disso, a utilização destes aplicativos comerciais por instituições de ensino e laboratórios como o Laboratório de Acessibilidade da Unicamp seria amplamente facilitada com o uso de software livre, uma vez que a obtenção do produto não fica dependente dos morosos procedimentos burocráticos para aquisição de recursos, procedimentos estes bastante frequentes nas instituições públicas de ensino.

Além do mais, o cenário atual que envolve as tecnologias assistivas é representado majoritariamente por entidades privadas; empresas e entidades que desenvolvem produtos nessa direção cobram, por seus produtos, valores que nem sempre são compatíveis com o orçamento de todos sem contar que as atualizações desses produtos, visando acompanhar a tecnologia e as mudanças de paradigmas, são dependentes dos reais interesses dos seus responsáveis ${ }^{21}$. Uma das premissas importantes a se garantir, portanto, é que um trabalho primordialmente voltado ao interesse social esteja de fato à disposição da sociedade que a demanda. Permitir que a comunidade participe ativamente do aperfeiçoamento do programa garante que futuras necessidades e adequações a novas realidades tecnológicas (como mudanças em sistemas operacionais, por exemplo) sejam atendidas com prontidão, uma vez que as atualizações do software não ficam dependentes da vontade ou dos interesses das empresas proprietárias.

\footnotetext{
${ }^{21} \mathrm{O}$ autor chegou a ter experiências com produtos que não acompanhavam, por exemplo, as atualizações dos sistemas operacionais que serviam de plataforma para os mesmos, obrigando o seu usuário a manter-se desatualizado por dependência destes aplicativos.
} 
A necessidade por trás desse desenvolvimento certamente vai ao encontro dos interesses sociais da atualidade, sobretudo dadas as evidências de carência de provimento de recursos tecnológicos com esta finalidade. É fundamental, portanto, que os resultados deste trabalho, tanto em seu caráter investigativo como colaborativo, possa ser colocado integralmente à disposição da comunidade, não só para sua própria expansão, mas também servindo como fonte de consulta, inspiração e até mesmo contraposição e debate.

\section{Suporte multi-idioma}

É fundamental para a prosperidade deste aplicativo que ele esteja preparado, desde sua concepção, para lidar com múltiplos idiomas, por motivos diversos. O uso de programas em idiomas os quais o usuário não é familiar pode não ser totalmente inviabilizado quando uma interface gráfica provê recursos visuais que colaborem com a interação e exploração do usuário; no caso em questão, porém, é esperado que a relação entre o usuário e o programa se dê unicamente por vias sonoras e, portanto, o caráter idiomático pode relacionar-se com a experiência de uso em sua totalidade. Além disso, é desejável também que se disponibilize uma maneira simples para que novos idiomas sejam adicionados, considerando a possibilidade da participação da comunidade de código aberto para colaborar com o melhoramento do aplicativo.

\section{Acessibilidade}

A navegação pelo programa deve ser concebida priorizando o uso do teclado, considerando que é o dispositivo que permitirá que cegos e videntes acedam igualmente às funcionalidades do programa. O mouse poderá ser utilizado para melhorar a interatividade de videntes, porém nenhum recurso do programa deverá ser acessado unicamente por este dispositivo, sem equivalência pelo teclado. É importante prover também, quando necessário, sinais sonoros além dos produzidos pelo leitor de tela, que substituam textos inconvenientes (por exemplo, indicar quando o usuário está no início ou fim de um compasso, ou indicar quando, na estrutura de navegação, o usuário pode escrever conteúdo em braille). 


\section{Capítulo 2}

\section{A Musicografia Braille}

O capítulo anterior apresentou uma série de conceitos e algumas direções do interesse comum social que tratam de educação e acesso à informação como direitos de todos, com enfoque nas especificidades da deficiência visual. No caso específico dessa pesquisa, a atenção concentra-se nos problemas enfrentados por deficientes visuais no ambiente de ensino superior de Música, onde é frequente a necessidade de ler, escrever e compartilhar música e, para tanto, videntes e cegos utilizam-se de sistemas de grafia diferentes.

A grafia em tinta foi desenvolvida para a visão; a leitura é realizada simultaneamente na horizontal e na vertical. É possível executar um instrumento durante a leitura e até mesmo simultaneamente à primeira leitura de uma obra. Um leitor bem treinado é capaz de antever os próximos compassos e assim preparar-se mais adequadamente para a execução. É possível alcançar rapidamente qualquer trecho de uma obra extensa buscando visualmente por determinadas estruturas musicais, e até mesmo verificar contrapontos, imitações, etc.

A musicografia braille, por sua vez, foi desenvolvida para a leitura pelo tato; A leitura é serial e orientada, sendo realizada da esquerda para a direita, linha por linha (Encelle et al., 2009), símbolo a símbolo, assemelhando-se mais ao modo pelo qual o leitor vidente lê um texto literário do que a leitura de uma partitura. Embora alguns leitores experientes em braille consigam solfejar ou mesmo dedilhar um piano simultaneamente à leitura tátil, a execução geralmente é feita mediante a memorização das obras. A quantidade de páginas de uma obra em braille é consideravelmente maior do que em tinta. Certas notações utilizam paradigmas diferentes, como por exemplo a grafia de acordes: um acorde é grafado em braille escrevendo a primeira nota e o número dos intervalos que compõem o acorde (ex.: Dó - terça - quinta ao invés de Dó - Mi - Sol, como será visto na seção 2.4). Essa diferença na notação de acordes faz com que a educação musical para deficientes visuais preocupe-se em apresentar o conceito de intervalos musicais (e toda a teoria correspondente) antes da leitura de acordes (Bonilha, 2010), o que não é necessariamente um requisito da grafia visual, que informa claramente as notas que devem ser executadas simultaneamente. Por outro lado, a transposição de um acorde é bastante simples em braille, bastando alterar a primeira nota - os intervalos seguirão a ordem; em tinta, seria necessário alterar todas as notas do acorde.

Apesar das dificuldades relacionadas ao uso e ao aprendizado desta grafia, a musicografia braille preserva-se soberana sobre todas as proposições de grafias alternativas que buscam substituí-la, e não por outro motivo senão pela ampla aceitação do código por parte de seus usuários. Este ponto é bastante relevante como justificativa deste trabalho não se preocupar, em momento algum, em buscar alternativas mais eficazes ou elegantes para a leitura e escrita tátil; ao invés disso, objetiva promover o código entre comunidades que se interessem em prover recursos que contribuam para seu uso e sua difusão.

Este capítulo procurará introduzir conceitos fundamentais da musicografia braille, chamando 
a atenção do leitor para uma grafia musical essencialmente tátil, baseada em paradigmas muito diferentes da grafia em tinta, sendo que o processo de conversão entre estas grafias não pode ser realizado por simples transliteração simbólica. As questões específicas mais marcantes da musicografia braille serão tratadas mais detalhadamente para que posteriormente possa ser discutido o processo de conversão automática entre as grafias.

\section{$2.1 \quad$ Histórico}

Em meados de 1825 foi inventado na França o sistema de leitura tátil por Louis Braille, cuja visão foi perdida em um acidente aos 3 anos de idade. Este sistema foi baseado originalmente a partir de uma forma de escrita em relevo criada pelo capitão de artilharia Carlos Barbier de la Serre (Portal Lerparaver, 2005), cuja intenção inicial era utilizar como uma forma de "escrita noturna", para que soldados conseguissem ler instruções em plena escuridão. Desde então, tal sistema tem sido utilizado universalmente não só para a leitura e escrita literária, mas também adaptado a outros diversos sistemas de notação específicos, como a grafia musical, matemática, estenografia e química. A Musicografia Braille, em particular, originou-se por mérito do próprio Louis Braille; em 1829, em sua obra Procédé pour écrire les paroles, la musique et la plainchant au moyen de points (Método para escrever as palavras, a música e o cantochão por meio dos pontos) (Tomé, 2003) Braille traz a público uma forma inédita de leitura e escrita tátil, baseada em conjuntos de seis pontos dispostos em forma de uma matriz de três linhas e duas colunas denominados celas, a serem marcados em alto-relevo em papel. Embora o alfabeto proposto por Braille tenha sofrido pouca alteração desde sua concepção, a escrita musical foi totalmente modificada pelo próprio autor, ao longo de sua vida, dando finalmente origem às bases que hoje compõem a musicografia braille.

Atualmente, a referência oficial para esta grafia é o Novo Manual Internacional de Musicografia Braille (União Mundial dos Cegos, 2004), resultado de uma série de estudos e revisões realizados em congressos organizados por um subcomitê dedicado ao assunto na União Mundial de Cegos (UMC), na intenção de padronizar e internacionalizar o código. A última versão do manual foi publicada em 1996 e, segundo o próprio subcomitê de Musicografia Braille, o objetivo do manual é que "os símbolos e as regras reunidos neste volume, segundo os acordos aceitos pela maioria, sejam usados com todo o rigor nas transcrições de música em braille", solicitando aos países que realizem a tradução do manual para seu idioma e que usem o mesmo em futuras edições musicais. Ademais, em caso de dúvidas, a versão original em inglês tem status de autoridade principal (de Souza, 2009).

\subsection{A cela e o alfabeto braille}

A marcação em papel dos símbolos braille é realizada mediante o uso de certas ferramentas especiais como o reglete, um dispositivo constituído de uma placa frisada ou com cavidades circulares e de uma régua com retângulos vazados (SEE/ME, 2002), que serve de amparo para que os pontos sejam marcados no papel utilizando o punção ${ }^{1}$. A escrita com o reglete é realizada ao contrário (da direita para a esquerda e com celas espelhadas), já que o alto-relevo será formado na parte contrária da folha, exigindo assim alguma prática de quem escreve por meio do aparelho.

A máquina Perkins é uma alternativa mais refinada de escrita em braille; assemelha-se a uma máquina de escrever, pesa aproximadamente $5 \mathrm{~kg}$ e possui seis botões para a produção dos pontos em relevo no papel, além de teclas para avanço e retrocesso do carro e mudança de linha. A máquina Perkins desobriga o usuário de escrever ao contrário, mas é bem mais cara e também menos

\footnotetext{
${ }^{1}$ Punção é o nome do ato (s.f.) e também do instrumento (s.m.).
} 
portátil que o reglete. Podemos ver, na figura 2.1, as ferramentas acima descritas.

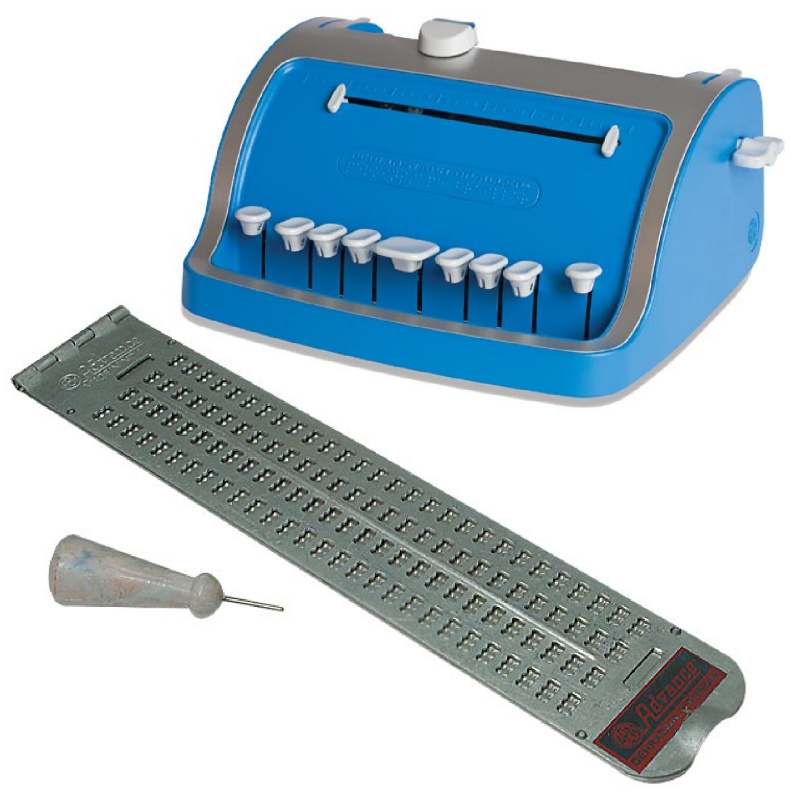

Figura 2.1: Máquina Perkins, reglete e punção - ferramentas da escrita braille.

A "cela braille" é um conjunto de seis posições de pontos, dispostos em três linhas e duas colunas enumeradas verticalmente de 1 a 6 , a serem marcados em alto-relevo no papel. A figura 2.2 mostra como os pontos são numerados e os dedos responsáveis por marcar cada um deles usando uma máquina Perkins. O ato de marcar ou não marcar os pontos nessas seis posições é o que origina os $2^{6}=64$ símbolos diferentes (incluindo o vazio, onde nenhum ponto é puncionado) que compõem o alfabeto braille.
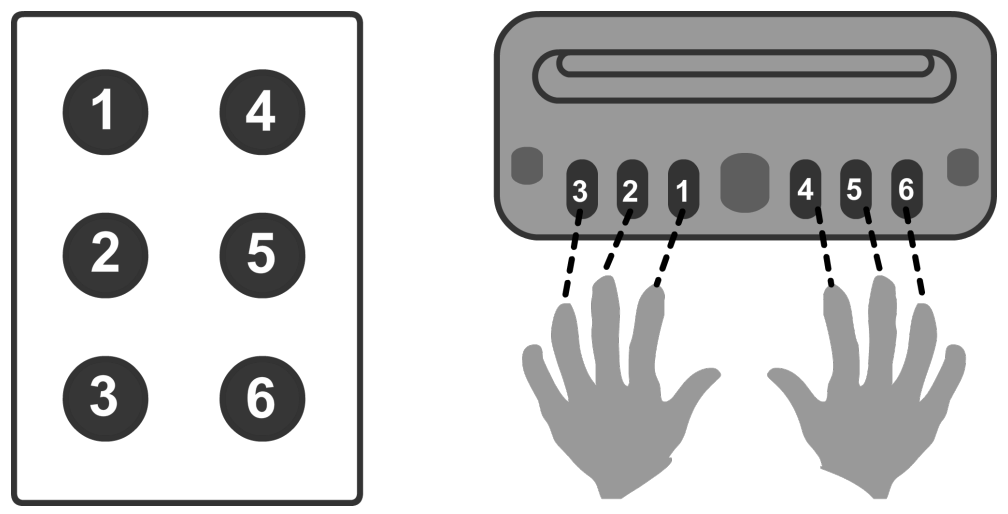

Figura 2.2: Numeração dos pontos em uma cela braille.

Existe uma versão estendida da cela braille que faz uso de oito pontos, aumentando a quantidade de símbolos distintos para 256. No entanto, o MIMB opta por utilizar apenas celas de seis pontos e, dados os objetivos deste trabalho, não será feita menção futura ao uso de celas de oito pontos.

A figura 2.3 representa o alfabeto braille adotado na grafia portuguesa. As primeiras 10 celas representam tanto as primeiras letras do alfabeto como os números, e fazem uso apenas dos pontos superiores - 1, 2, 4 e 5. Os próximos conjuntos de celas são iguais ao primeiro, com a adição do ponto 3 para o segundo conjunto, 3 e 6 para o terceiro, e do ponto 6 para o quarto. Como pode ser visto na figura 2.4, a representação das notas musicais faz uso desta mesma organização das celas. 


\begin{tabular}{|c|c|c|c|c|c|c|c|c|c|c|}
\hline \multirow[t]{3}{*}{ Símbolos básicos: } & $\because$ & $\because:$ & $\because:$ & $\because:$ & $\because$ & $\because:$ & $::$ & $\because:$ & $\ddot{\vdots}$ & $: \vdots$ \\
\hline & $\mathrm{A}$ & B & $\mathrm{C}$ & $\mathrm{D}$ & $\mathrm{E}$ & $\mathrm{F}$ & $\mathrm{G}$ & $\mathrm{H}$ & I & $\mathrm{J}$ \\
\hline & 1 & 2 & 3 & 4 & 5 & 6 & 7 & 8 & 9 & 0 \\
\hline \multirow[t]{2}{*}{ com ponto 3 : } & $\because:$ & $\vdots:$ & $\because \because$ & $\because:$ & $\because$ & $\because:$ & $::$ & $\because:$ & $\because:$ & $::$ \\
\hline & K & $\mathrm{L}$ & M & $\mathrm{N}$ & $\mathrm{O}$ & $\mathrm{P}$ & $\mathrm{Q}$ & $\mathrm{R}$ & $\mathrm{S}$ & $\mathrm{T}$ \\
\hline \multirow[t]{2}{*}{ com ponto 3 e 6 : } & $\because \vdots$ & $\vdots \vdots$ & 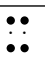 & $\ddot{: !}$ & $\because \vdots$ & $\ddot{\vdots}$ & ::: & $\because:$ & $\vdots \vdots$ & $: \vdots$ \\
\hline & $\mathrm{U}$ & V & $\mathrm{X}$ & $\mathrm{Y}$ & $\mathrm{Z}$ & Ç & É & Á & $\grave{\mathrm{E}}$ & Ú \\
\hline \multirow[t]{2}{*}{ com ponto 6 : } & $\because$ & $\because$ & $\because !$ & $\because:$ & $\because$ & $\because:$ & :: & $\because:$ & $\because$ & $\because:$ \\
\hline & $\hat{\mathrm{A}}$ & $\hat{\mathrm{E}}$ & İ & $\hat{\mathrm{O}}$ & $\grave{U}$ & $\grave{A}$ & $\ddot{\mathrm{I}}$ & $\ddot{U}$ & $\tilde{O}$ & Ò/W \\
\hline
\end{tabular}

Figura 2.3: Alfabeto braille utilizado na língua portuguesa

\subsection{Símbolos Indicadores do braille}

Os símbolos indicadores aqui descritos referem-se a uma prática comum no braille, não apenas na musicografia, que diz respeito à promoção de certos símbolos para propósitos especiais. É importante mencioná-los aqui, pois muitas das regras da musicografia braille os utilizam, como será demonstrado adiante. Para os leitores em tinta, a prática de uso destes símbolos da maneira como é realizada em braille pode não ser tão óbvia, carecendo assim de esclarecimento.

Os símbolos indicadores têm como função alterar propriedades contextuais, semânticas ou mesmo tipográficas de um determinado grupo de caracteres, e podem ser classificados de acordo com sua função no texto.

\section{Indicadores de marcação e terminação}

Os símbolos classificados como indicadores de marcação ou composição são aqueles que precedem o conteúdo a ser afetado. Os indicadores de terminação têm como objetivo interromper as alterações criadas pelos indicadores de marcação. Assemelha-se, num primeiro momento, ao uso das tags nas linguagens de marcação, como o HTML, onde o conteúdo a ser processado é colocado entre símbolos específicos. Como exemplo, o seguinte código escrito em HTML:

"Isso é um exemplo de $<\mathrm{i}>$ uso de tags $</ \mathrm{i}>$ na linguagem $<\mathrm{b}>\mathrm{HTML}</ \mathrm{b}>$ "

produz o seguinte resultado:

"Isso é um exemplo de uso de tags na linguagem HTML".

Os indicadores de marcação no braille, no entanto, não possuem necessariamente uma sintaxe tão clara e formal como na linguagem HTML; essa linguagen de marcação foi desenvolvida originalmente para que fosse a priori processada por computadores, ainda que seja razoavelmente legível pelo homem. Já no braille, esses indicadores foram idealizados essencialmente para a leitura e compreensão humana e, nesse caso, a formalidade sintática pode ser entendida como a própria interpretação do leitor. Isso significa que os indicadores de marcação podem não vir acompanhados de terminadores ${ }^{2}$, dependendo da situação, economizando assim no tamanho do texto e evitando a leitura desnecessária de símbolos. Certamente o uso destes sinais indicadores de contexto dificultam expressivamente o aprendizado do sistema braille de forma geral, mas há de se levar em consideração que estes têm como função possibilitar que se faça a representação de uma gama muito grande de elementos (textuais e não-textuais) utilizando um alfabeto bastante limitado, muitas vezes insuficiente para um determinado propósito. Os exemplos a seguir demonstram o uso destes sinais:

\footnotetext{
${ }^{2}$ de fato há terminadores, seja o início de outro indicador de marcação, ou mesmo uma quebra de linha, sendo portanto regido por uma regra geralmente mais complexa do que um caractere ou símbolo dedicado a esse fim. Devese ter em mente que a grafia braille desenvolveu-se como uma linguagem natural para leitura humana; terminadores como em marcações do HTML são característicos de linguagens formais com gramáticas regulares livres de contexto.
} 
Exemplo 1 - Letras maiúsculas e minúsculas: Os símbolos utilizados para grafar letras são os mesmos para as formas maiúsculas e minúsculas. Por padrão, um símbolo de letra a representa em sua forma minúscula; um indicador de contexto é responsável pela transformação do símbolo para caixa alta. Conforme a Grafia Braille para a Língua Portuguesa, "As letras maiúsculas representam-se pelas minúsculas precedidas imediatamente do sinal $: \vdots$ (46), com o qual formam um símbolo composto". Abaixo, a demonstração completa da regra de emprego de caixa alta:

- Usa-se o sinal de maiúscula $\vdots$ quando só a primeira letra da palavra for maiúscula - ex:": Cascavel".

- Usa-se o sinal de maiúscula duas vezes [ $\left[\begin{array}{l}\vdots \\ \vdots\end{array}\right]$ quando todas as letras da palavra forem maiúsculas - ex. “... no $: \vdots$ BRASIL aconteceu ....".

- Em uma frase que contenha até quatro palavras, todas em maiúscula, usa-se o sinal $\quad \vdots$ duas vezes antes de cada palavra - ex.: ":! : PROFESSORES $\vdots:$ EXIGEM $\vdots:$ REPOSIÇÃO $\because$ : SALARIAL".

- Em frases com cinco ou mais palavras, todas em maiúscula, usa-se os pontos início da frase e o sinal de maiúscula $\vdots$ por duas vezes antes da última palavra - ex.: “: : : A UNIVERSIDADE ESTÁ OFERECENDO CURSOS PREPARATÓRIOS PARA : : ESTUDANTES do ensino público."

Exemplo 2 - Palavras sublinhadas: Para o sinal de grifo (até quatro palavras grifadas), escreve-se o sinal de grifo antecedendo cada uma delas: "O sorriso é o idioma do amor : Num grupo com mais de cinco palavras grifadas, procede-se assim: escreve-se os pontos :: seguidos do sinal de grifo $:$ antes da primeira palavra grifada e novamente o sinal de grifo antes da última palavra: "Nós : : $:$ envelhecemos porque abandonamos o nosso : : ideal".

Estes marcadores são motivo de especial atenção nos processos de conversão de braille para tinta. Quando os símbolos terminadores não estão presentes, é necessário avaliar muito detalhadamente a regra de uso, que em alguns casos pode resultar em ambiguidades que deverão ser tratadas separadamente.

\section{Indicadores de mudança de contexto}

Devido à limitação de combinações possíveis, uma mesma configuração de pontos em uma cela braille pode ser utilizada para representar vários símbolos, desde que pertençam a contextos semânticos diferentes. As primeiras nove letras do alfabeto, por exemplo, são representadas pelas mesmas celas que representam os números de 1 a 9 , como pode ser visto na figura 2.3. Semelhantemente, os símbolos para representar as letras entre "d" e "j" são os mesmos que representam as notas de dó a si, como pode ser visto na figura 2.4. Para permitir a leitura correta dos possíveis significados dos símbolos, a grafia braille utiliza os indicadores de mudança de contexto (change-of-semantics indicators, que indicam o teor do conteúdo que o seguirá. O exemplo mais simples é o de números e letras. Em texto convencional, o caractere : (\#) indica que os caracteres seguintes não são mais letras e sim números (até a ocorrência do próximo espaço em branco). Dessa forma, o texto "CASA 31" seria escrito em braille da seguinte forma:

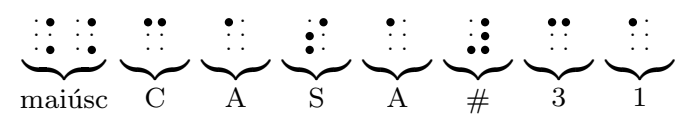




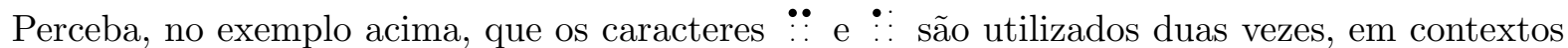
diferentes. É possível perceber que a mudança de contextos provocada por símbolos alteradores, como é o caso dos sinais de número de palavra, não alteram simplesmente a interpretação de símbolos. Existem outros marcadores e terminadores, também responsáveis pela determinação de contextos, que são subordinados aos anteriores, os quais fazem sentido apenas no contexto regido pelo seu antecessor. Assim sendo, o sinal para maiúsculas e minúsculas no contexto numérico não faz sentido, sendo este um alterador de contexto subordinado ao contexto de palavra, ou literário.

\subsection{Elementos musicais}

Esta seção demonstrará de forma resumida os principais símbolos musicais presentes na musicografia braille.

\section{Notas musicais e pausas}

A grafia das notas musicais é um bom ponto de partida para o entendimento da sistematização da musicografia braille. Em primeiro lugar, é importante esclarecer que essa forma de escrita faz uso dos mesmos símbolos usados para escrever números e letras. A grafia mais simples é a das colcheias; as notas de dó a si seguem literalmente a ordem das letras de "d" a "j", usando apenas os quatro pontos superiores das celas. As notas de outras durações (semínimas, mínimas, etc.) são idênticas às colcheias, com a adição dos pontos inferiores (3 e/ou 6), como pode ser visto na figura 2.3. A tabela 1-A do MIMB é a referência fundamental para toda a musicografia, especificando a grafia das notas e pausas (figura 2.4).

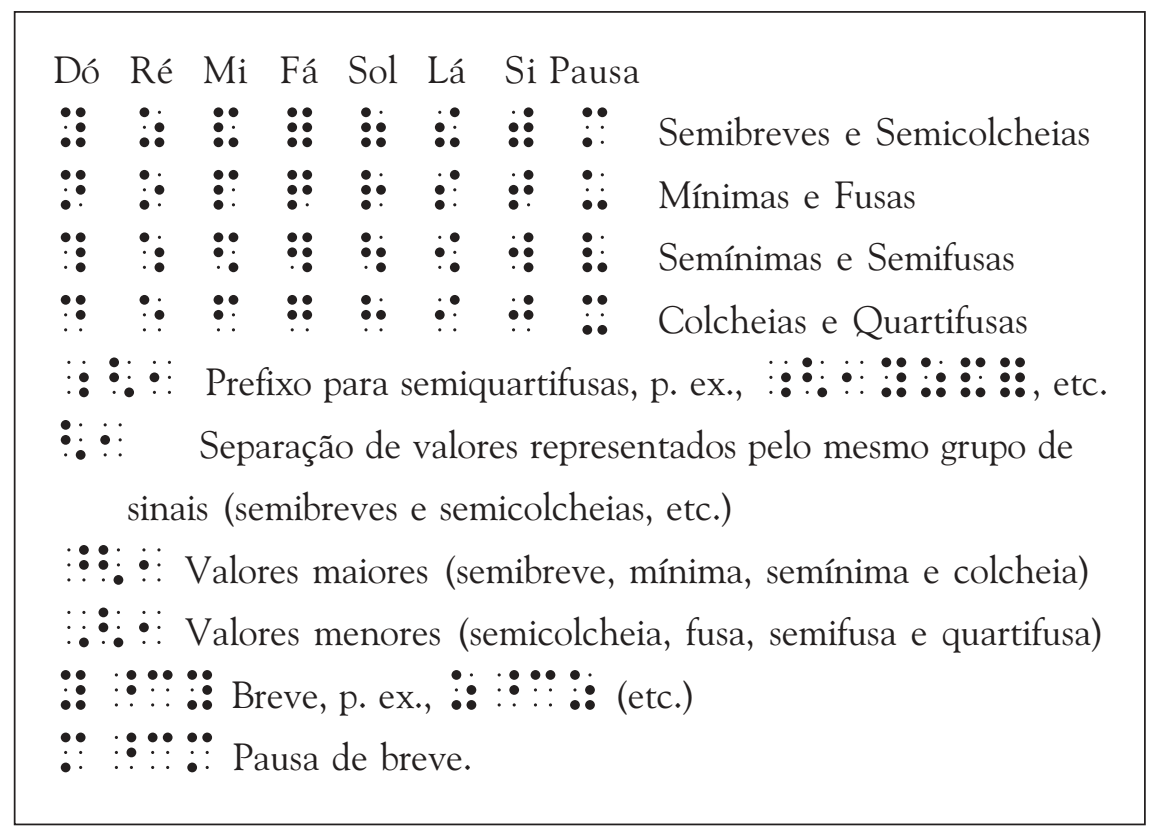

Figura 2.4: Tabela 1-A do MIMB: notas musicais e pausas

\section{Alterações}

Os símbolos de sustenido, bemol ou bequadro são colocados antes das notas, intervalos ou outros elementos que alteram, podendo separar-se das notas por, no máximo, um sinal de oitava. 


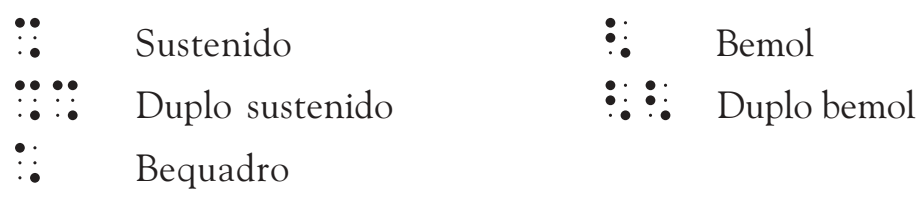

Figura 2.5: Alterações

\section{Oitavas}

Anteriormente vimos como um único símbolo é capaz de representar tanto a duração quanto a altura da nota. Porém, essa informação sozinha não é suficiente para indicar a qual oitava ela pertence. Existe então um conjunto de sinais utilizados para este fim, demonstrados na figura 2.6. O sinal de oitava deve ser colocado imediatamente antes da nota a qual se refere. A primeira nota de uma peça ou parágrafo deve ser precedida de seu sinal de oitava. Para as demais notas, as seguintes regras devem ser aplicadas:

(a) Se duas notas formam um intervalo de segunda ou terceira ascendente ou descendente, a segunda delas não leva um sinal de oitava, mesmo se pertencer a uma oitava diferente da primeira nota.

(b) Caso formem um intervalo de quarta ou quinta ascendente ou descendente, a segunda nota só leva sinal de oitava se pertencer a uma oitava diferente da primeira.

(c) Caso formem um intervalo de sexta ou maior, a segunda nota deve levar sempre o sinal de oitava.

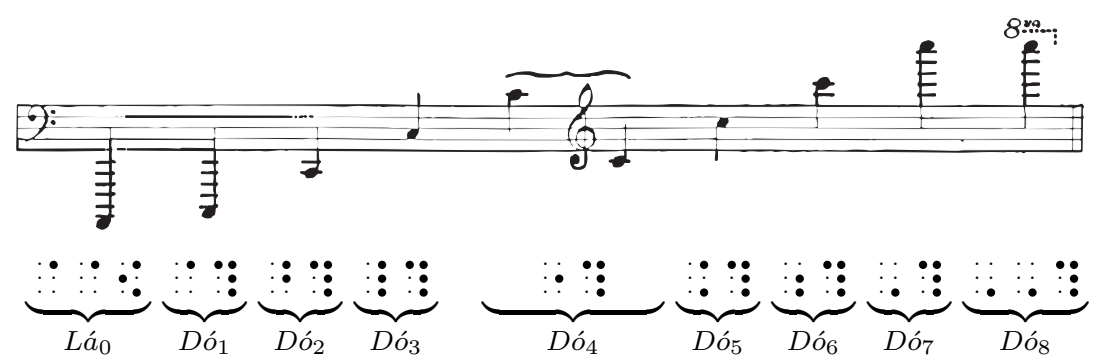

Figura 2.6: Sinais de oitavas

\section{Claves}

A notação em braille não utiliza os símbolos de claves para determinar a altura das notas. Porém, a musicografia braille possui sinais de indicação de clave, e o conhecimento desses símbolos se faz necessário para a compreensão exata, pelo cego, da partitura original em tinta. Na partitura em tinta, este símbolo é repetido em cada pauta, enquanto que em braille este símbolo só ocorre no início da obra, para cada instrumento, ou quando se produz mudança de clave. A figura 2.7 mostra alguns símbolos utilizados para representar claves.

\section{Mão direita e mão esquerda}

Como já foi dito anteriormente, a indicação de claves não é utilizada no braille. Em uma partitura para teclado, por exemplo, convenciona-se o uso de um sistema de duas pautas, a primeira na clave de sol, para a mão direita, e a segunda na clave de fá, para a mão esquerda. A leitura a duas mãos em braille, porém, não é feita simultaneamente. Utiliza-se para esse fim um sinal não existente na musicografia em tinta, que indica qual mão deverá tocar o trecho que o seguirá. Usa-se as celas $: \vdots:$ para indicar a mão esquerda e $: \vdots:$ para a mão direita. 


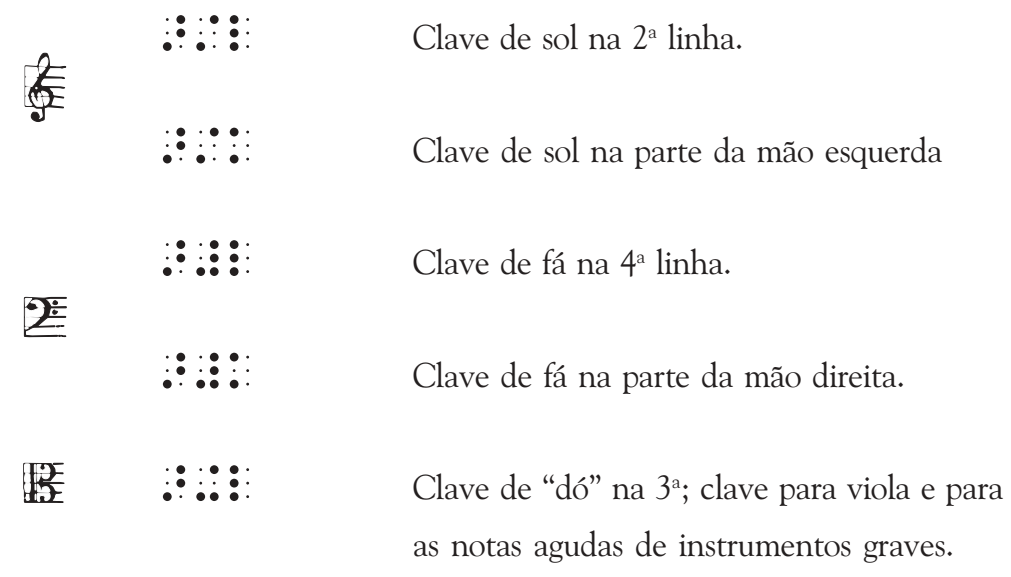

Figura 2.7: Representação em braille dos símbolos de clave

\section{Grupos rítmicos}

O agrupamento de notas ocorre na notação musical em tinta ligando notas de curta duração (colcheias, semicolcheias e inferiores) com uma ou mais barras horizontais. Este agrupamento auxilia a leitura criando uma subdivisão rítmica do compasso. Existe uma forma de se criar grupos rítmicos também em braille, porém a maior importância de usá-los é facilitar a punção dos pontos. Além disso, tal recurso também é fundamental por permitir uma transcrição sem perdas entre as grafias.

O agrupamento rítmico é feito escrevendo a primeira nota em sua forma própria e as demais notas agrupadas como colcheias. Dessa forma, a sequência de semicolcheias dó, ré, mi, fá, sol, lá, si, dó é escrita como $:$ : : : : : : : : : : : : na forma desagrupada, e pode ser escrita como : : : : : : : : : : : : : $:$ : na forma agrupada em dois grupos de quatro semicolcheias.

A figura 2.8 demonstra o emprego de alguns dos elementos musicais apresentados até o momento.
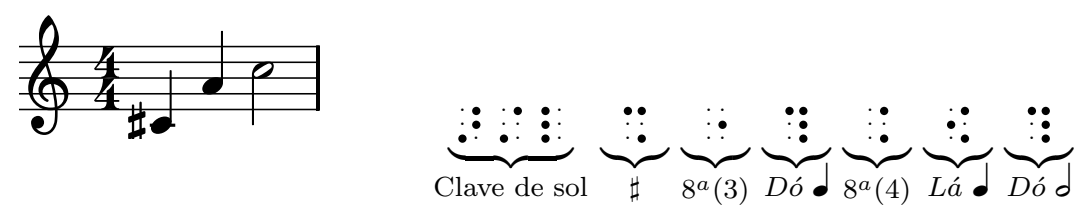

Figura 2.8: Representação em braille de um compasso.

\section{Acordes e intervalos}

Para escrever acordes e intervalos, escreve-se a primeira nota em sua forma habitual e as demais utilizando os sinais de intervalo representados na figura 2.9. Para instrumentos no registro agudo, escreve-se a nota mais aguda e as demais como intervalos descendentes; para instrumentos no registro grave, escreve-se primeiro a mais grave e as demais como intervalos ascendentes. Vale também comentar que alterações são indicadas antes do sinal do intervalo correspondente. 


$\begin{array}{llll}\because & \text { Segunda } & \vdots: & \text { Sexta } \\ \because: & \text { Terceira } & \vdots: & \text { Sétima } \\ \vdots: & \text { Quarta } & \vdots: & \text { Oitava } \\ \vdots & \text { Quinta } & & \end{array}$

Figura 2.9: Sinais de Intervalo

\section{Em Acorde}

A maneira que a musicografia braille usa para representar vozes simultâneas em um mesmo pentagrama é escrevendo-as sucessivamente no compasso unidas pelo sinal chamado de em acorde: :. : A ordem de leitura é a mesma dos intervalos: escreve-se primeiro as vozes mais agudas para instrumentos de registro agudo (onde a ordem dos intervalos é descendente) e o oposto para os instrumentos de registro grave, conforme indicado no exemplo 2.10.

Quando apenas uma fração do compasso deve receber o em acorde, emprega-se então o sinal : : : para indicar a próxima voz. Neste caso, o sinal $\quad \vdots \vdots \vdots$ : deverá preceder o trecho onde será iniciada a segunda voz.

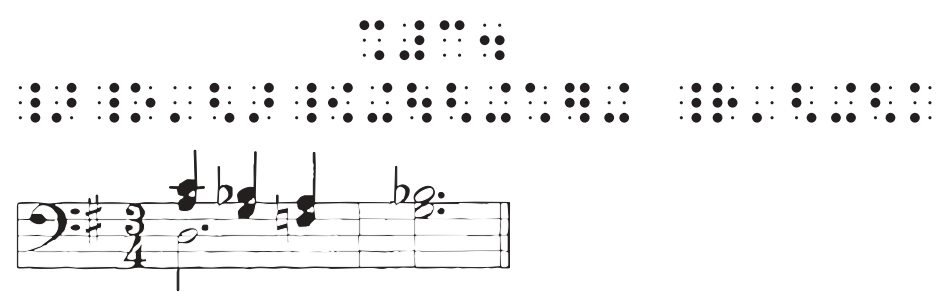

Figura 2.10: Emprego do "Em Acorde"

\section{Ligaduras de Expressão}

Na musicografia Braille, o uso de ligaduras de expressão em um grupo grande de notas é realizada mediante o uso de indicadores de contexto. O capítulo VI do Manual Internacional de Musicografia Braille trata do uso de ligaduras da seguinte maneira: para até quatro notas ou acordes ligados, utiliza-se o sinal $\because:$ colocado depois de cada nota, salvo na última (como na figura 2.11). Quando uma ligadura contém mais de quatro notas, pode ser transcrita em braille de duas maneiras apresentadas abaixo e representadas pela figura 2.12 :

(a) O sinal : : se duplica depois da primeira nota e se repete na forma simples, depois da penúltima.

(b) Coloca-se o sinal $: \vdots$ antes da primeira nota e o sinal $: \vdots$ depois da última.

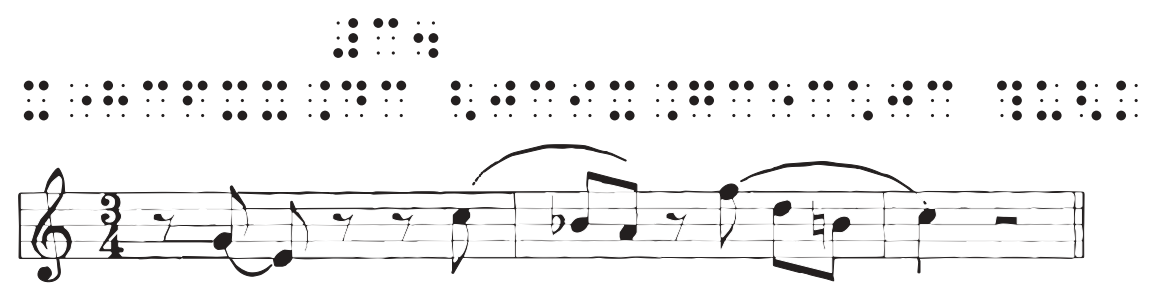

Figura 2.11: Uso do sinal de ligadura para até quatro notas. 
(a)

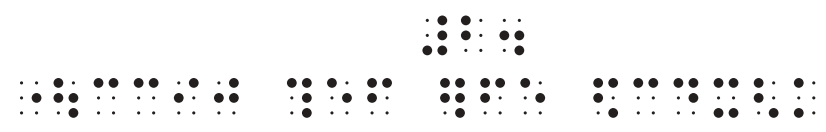

(b)

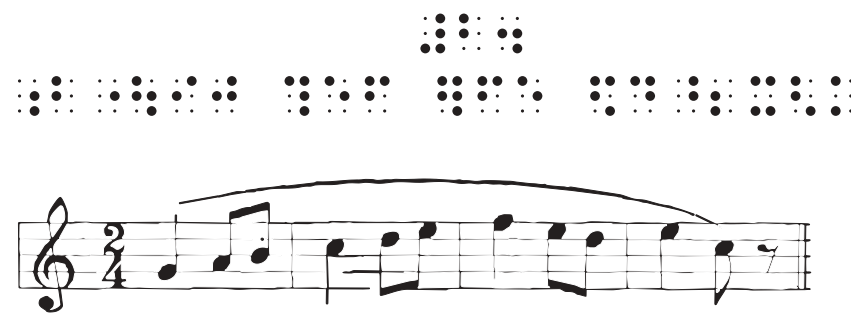

Figura 2.12: Duas opções de sinais para ligaduras envolvendo mais de quatro notas.

\section{Repetições}

O capítulo 9 do MIMB trata da representação das repetições musicais em braille. Além de contemplar os sinais de repetição existentes na musicografia em tinta, como pontos de repetição, "casa 1" e "casa 2", dal segno / coda, etc., existem símbolos que são próprios da musicografia braille para poupar espaço e facilitar a leitura e a memorização.

O sinal :: é um símbolo de repetição sem equivalência na forma impressa em tinta. Neste caso, o aparecimento deste símbolo pede ao leitor para repetir a parte que o antecedeu, desde algum ponto que eventualmente pode transcender os limites do compasso em questão. Embora sua regra não seja tão simples, exigindo do leitor boa intuição e alguma formação musical, este símbolo pode economizar muito na digitação das celas e até mesmo na quantidade de papel utilizado para impressão, em determinados casos.

Existem os casos de "repetição parcial", onde uma fração do compasso deve ser repetida dentro dele mesmo. Para tanto, essa repetição parcial deve obedecer a algumas regras: não deve ser usada no início do compasso nem no começo de uma nova linha em braille. Além disso, o uso das ligaduras combinadas com as repetições parciais requer cuidado. O exemplo da figura 2.13 demonstra o uso de repetições dentro de um compasso:

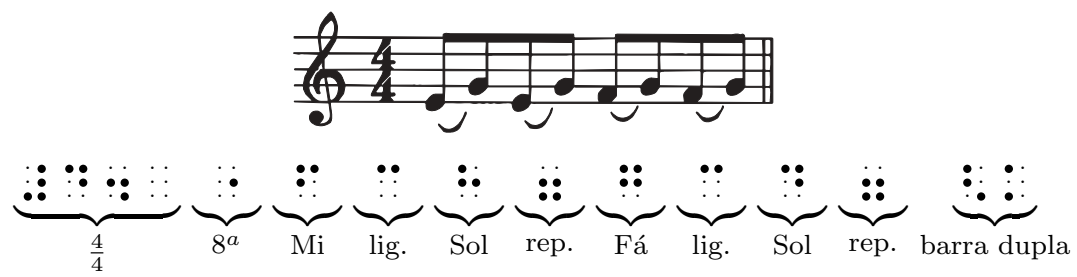

Figura 2.13: Exemplo de repetição parcial em braille

\section{Quiálteras}

As quiálteras são representadas em sua maioria por indicadores de marcação sem terminação, a não ser as tercinas que podem ser escritas entre os símbolos : : como é demonstrado na figura 2.14. Essa escrita simplificada de tercina é mais comum, sendo a segunda forma (de três celas combinadas) utilizada num segundo nível de agrupamento, estando dentro de outra tercina ou mesmo de outros grupos rítmicos. Quando a partitura é composta de um trecho longo de quiálteras, 
é possível escrever o sinal de agrupamento duas vezes seguidas, indicando continuidade na aplicação da alteração rítmica.

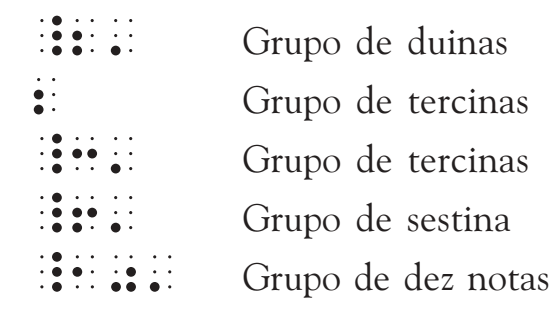

Figura 2.14: Tabela de símbolos para quiálteras

\subsection{Uso de indicadores no contexto da musicografia braille}

É possível encontrar, tanto em um texto como em uma partitura em braille, aninhamentos de indicadores de marcação, terminação e alteração semântica, exigindo uma sistemática de leitura diferente, onde iniciar a leitura de um ponto qualquer de uma página pode não ser possível, já que pode ser necessário ter conhecimento do conteúdo anterior para que haja o entendimento do significado dos símbolos a partir daquele ponto.

Na musicografia braille também verificam-se casos onde a ambiguidade de sinais se dá dentro do mesmo grupo semântico. A própria grafia das notas musicais é feita sob essa ótica: o símbolo :: por exemplo, é usado para representar uma nota dó tanto em semicolcheia como em semibreve, e o símbolo :: representa uma nota dó mínima ou fusa (ver figura 2.4. Embora existam símbolos que garantam a desambiguação (a sequência : : : : $:$ indica os valores maiores - semibreves, mínimas, semínimas e colcheias, enquanto que a sequência $: \vdots$ : fusas, semifusas e quartifusas) eles só são obrigatórios quando a soma das durações das notas em um compasso cria mais de uma situação possível ou quando notas com mesma representação são dispostas consecutivamente, como por exemplo uma semínima seguida de uma semifusa. Para o caso de duas notas de duração diferente representadas pela mesma cela braille, particularmente quando é sabido pelo leitor o valor da primeira, pode-se também usar o sinal de separação de valores, que não indica que a próxima nota pertence ao grupo de valores maiores ou menores, mas sim que pertence ao grupo oposto ao da nota anterior. Na regra 1-4 (União Mundial dos Cegos, 2004) temos:

Quando em um compasso não seja possível determinar com precisão o valor de uma nota ou pausa, recorre-se ou ao sinal de separação de valores ou aos sinais de valor maior ou menor, conforme o caso.

A interpretação do código torna-se ainda mais complicada com certas regras adicionais, como as de agrupamento de notas, já descritas anteriormente. Uma pessoa que esteja lendo uma determinada sentença consegue entender com alguma facilidade que aquilo representa um agrupamento de notas ou colcheias, pois essa pessoa faz uso de toda uma experiência com a obra que está sendo lida (ou até mesmo por experiências mais amplas, como do estilo musical) que lhe permite descartar rapidamente interpretações errôneas. A leitura por computadores, porém, requer uma outra abordagem, que será apresentada na seção 4.5 .

É importante para o processo de tradução automática das linguagens musicais aqui envolvidas que estes indicadores de mudança sejam entendidos de maneira sistemática. A figura 2.15 mostra um esquema das formas mais recorrentes na musicografia braille. Considere os triângulos pretos como sendo um desses indicadores, ou seja, um símbolo composto de uma ou mais celas que tem 


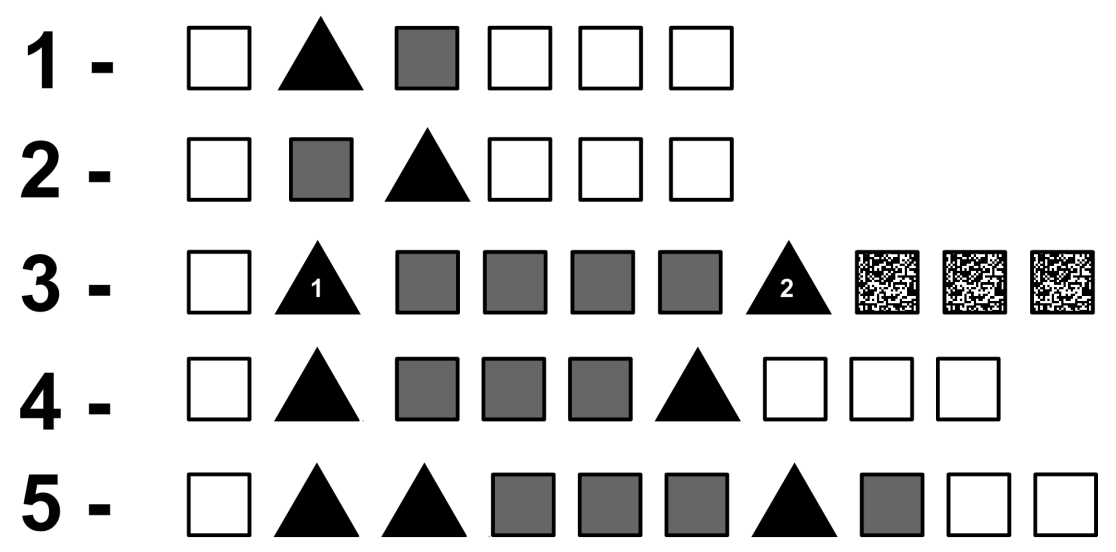

Figura 2.15: Esquema dos principais indicadores de mudanças na musicografia braille

capacidade de alterar propriedades de outros símbolos. Os quadrados de cor cinza são os símbolos afetados por estes últimos, ou seja, são aqueles que tiveram alguma de suas propriedades alteradas; quadrados com textura são os que sofreram alteração, porém não a mesma dos indicados por quadrados cinza. Quadrados brancos representam símbolos que não sofreram nenhuma alteração.

1. Nessa primeira forma, o indicador de mudança age tão somente sobre o símbolo que o sucede. É facilmente encontrada na indicação de acidentes ocorrentes, por exemplo.

2. Nessa segunda forma, o indicador de mudança age sobre o símbolo que o precede. Símbolos de notas pontuadas podem ser entendidos como indicadores deste caso, bem como os sinais de digitação, onde a indicação de dedo é disposta imediatamente após a nota à qual se refere.

3. No terceiro caso, o indicador de mudança age sobre todos os símbolos que o sucedem até que um outro indicador de mesmo contexto ou teor reivindique outra mudança. É o caso, por exemplo, dos sinais de mudança de oitava. A alternância de linhas melódicas e linhas vocais (com letras) também ocorre por meio de indicadores deste tipo. As barras de divisão de compasso (incluindo a simples, representada por um espaço em branco) também podem ser entendidas por este caso.

4. Este quarto caso expressa um comportamento de bloco, onde os símbolos sujeitos à alteração são dispostos entre dois símbolos iguais, que definem a mudança a ser efetuada. É o caso, por exemplo, de blocos de texto (palavras ou frases) dispostos no meio do conteúdo musical.

5. Neste último caso, o símbolo modificador é repetido duas vezes e modifica todos os símbolos vindouros até que o símbolo modificador apareça mais uma vez, sinalizando que a alteração se encerra necessariamente no próximo símbolo. Encelle et. al. (Encelle et al., 2009) define este caso como uma característica bastante particular da musicografia braille, com potencial para economia de símbolos. É encontrado com frequência em repetições de intervalos, como por exemplo em uma frase melódica com terças dobradas.

O símbolo de ligadura assume o comportamento definido em (1) quando atua como ligadura de expressão entre duas notas de mesma altura, e assume o comportamento definido em (5) quando atua como ligadura de fraseado para quatro ou mais notas. Esta mesma ligadura, porém, pode ser representada por um símbolo que assume o comportamento indicado em (4). Esses casos estão ilustrados nas figuras 2.11 e 2.12. Outro caso onde há ocorrência destes mesmos três comportamentos é o das alteração de maiúsculas e minúsculas em texto literário, conforme foi apresentado na seção 2.3 , onde este conceito foi introduzido.

Os exemplos referidos acima mostram que, a partir dessa sistematização, não há uma separação real do que são elementos musicais e o que são alteradores de propriedades dos mesmos; os símbolos 
que alteram propriedades podem também ser, ao mesmo tempo, elementos musicais. De fato, é necessário entender cada símbolo musical em braille sob estes aspectos: o que o símbolo representa, quais são suas propriedades inerentes e qual é a sua atuação em relação aos outros símbolos que o precedem ou sucedem. Este pensamento é particularmente importante para definir o processo de tradução das linguagens em etapas, baseando-se nas hierarquias e na interdependência dos símbolos de forma geral.

\subsection{Agrupamentos de símbolos}

Uma questão importante a ser abordada é a quantidade de celas braille necessárias para representar um símbolo ou uma informação grafada originalmente em tinta. Existem casos onde há uma correspondência quantitativa direta (cada algarismo numérico é representado por uma única cela, por exemplo), mas excetuando-se tais situações ainda existem casos onde várias celas são recrutadas para representar um único símbolo e casos onde uma cela é responsável por um conjunto de informações, como pode ser percebido logo na primeira tabela de notas e pausas (União Mundial dos Cegos, 2004): uma cela é responsável por representar tanto a altura (dó, ré, mi, fá...) como a duração (colcheia, semicolcheia, mínima, semínima, breve...) das notas; porém, a cela em si não informa a qual oitava aquela nota pertence, necessitando assim ser precedida de uma cela que a posicione na oitava correta. Desta forma, evidencia-se que o processo de tradução entre as linguagens musicais aqui envolvidas não pode ser realizado por meio de mera transliteração de caracteres.

\subsection{Aspectos regionais}

A escrita literária em braille está sujeita a variações regionais, criadas para resolver questões idiomáticas de cada país ou região, principalmente no que diz respeito a variações entre os alfabetos e contrações próprias dos idiomas. Também é importante notar que algumas regiões adotam preferencialmente a grafia com oito pontos por cela ao invés de seis. A Musicografia Braille, no entanto, preza pela universalização do código, que foi desenvolvido de forma colaborativa por representantes de diversos países. Por conta disso, o MIMB recomenda que as contrações literárias não sejam utilizadas, dado que elas variam de acordo com cada região. Também recomenda-se que, no início de cada obra, sejam apresentados e descritos eventuais caracteres acentuados que sejam particulares do idioma em questão, já que as celas que os representam podem ser utilizadas, em algum outro idioma, para representar um caractere diferente.

\subsection{Linhas vocais}

Linhas vocais contêm o texto a ser cantado separadamente da melodia à qual faz referência. A linha de texto vocal deve ser escrita alternadamente com a sua linha melódica, com indentação extra de dois espaços no início de cada bloco. Diferentemente da linha melódica, a linha vocal não é dividida por compassos; cada linha vocal deve conter exatamente o texto que compreende os compassos da linha melódica do mesmo bloco. Por padrão, a divisão silábica das palavras acompanha as mudanças de notas, salvo quando ligaduras (na linha vocal ou na linha melódica) modifiquem a relação entre notas e sílabas. Como dito anteriormente, o MIMB recomenda que não se utilize as contrações do braille literário por questões de universalização do código; neste caso em particular, solicita-se adicionalmente não fazer uso de contrações por conta da importância da clareza na escrita quanto às divisões silábicas. A figura 2.16 ilustra o paralelismo entre as linhas vocais de texto e melódica. 


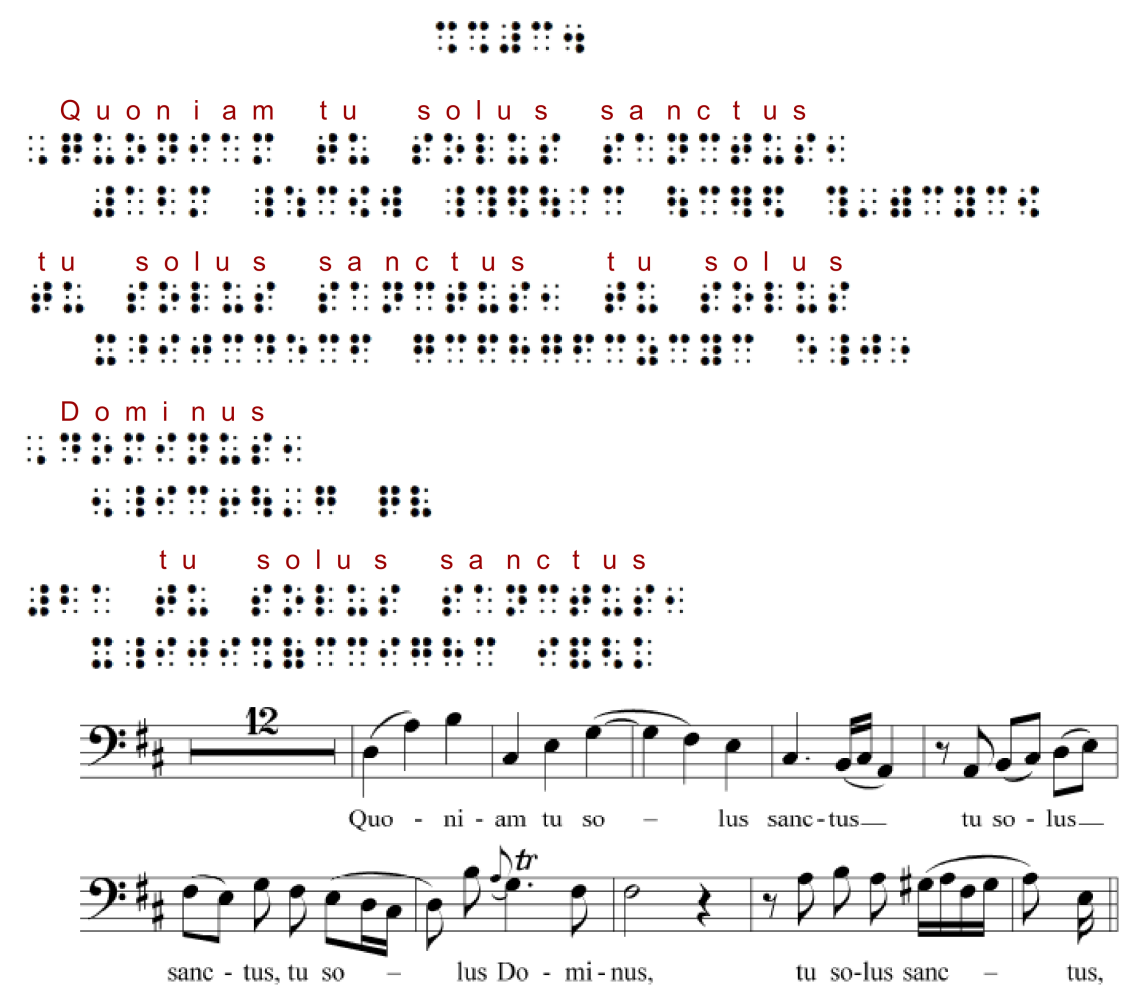

Figura 2.16: Linha vocal acompanhando linha melódica

\subsection{Diagramação e formatação da partitura em braille}

A disposição das informação musical em uma partitura em tinta permite que o músico vidente seja capaz de ler vários pentagramas simultâneos; Esta é uma necessidade frequente, sobretudo quando trata-se de música para teclados, com pentagramas separados para cada mão (ocasionalmente para os pés, no caso do órgão) ou de música vocal, onde a letra da música acompanha uma melodia.

A leitura em braille, porém, faz uso de um ou dois dedos no máximo, de forma que o acesso simultâneo à informação não é muito abrangente, embora ainda assim seja bastante desejado. A versão em inglês do MIMB versa sobre algumas possibilidades de formatação do documento para que, ainda que leitura paralela não seja totalmente eficiente, o leitor possa ter um padrão de organização de forma a poder criar uma sistemática de leitura adequada para sua necessidade. Nesta versão do manual, podemos destacar os seguintes formatos:

\section{Compasso sobre compasso (Bar over bar)}

Neste formato, duas ou mais linhas são agrupadas e definidas como "paralelas". As linhas que compõem tal agrupamento seguirão juntas, dispostas uma abaixo da outra, por um número prédefinido de compassos. O exemplo da figura 2.17 mostra uma partitura para piano de cinco compassos, onde a versão em braille está no formato compasso sobre compasso. No topo da partitura está a fórmula de compasso (1) indicando compasso de $2 / 2$. No início de cada bloco das paralelas há um indicador da numeração do compasso (2); neste caso em particular, o primeiro número indica zero ( $: \vdots$ ), pois a música inicia-se em anacruse. O próximo indicador é representado por duas celas $(\because: \vdots)$, e refere-se ao remanescente do compasso 3 , iniciado no primeiro bloco.

Quanto à distribuição dos símbolos neste formato, é importante também notar outros aspectos:

- A fórmula de compasso é posicionada no começo do conteúdo e no meio da página. 
- Contam-se alguns poucos espaços distantes da margem esquerda da partitura, destinados para uso apenas dos indicadores de numeração de compasso.

- Em partituras para teclado, as linhas devem ser iniciadas com as indicações de mão.

- Os blocos de cada compasso devem ser alinhados verticalmente, de forma que os compassos de mesmo número das linhas paralelas tenham o mesmo tamanho (o tamanho do compasso mais extenso); essa "espera" poderá ser grafada com espaços em branco desde que não exceda o máximo de seis espaços, e acima desta quantidade deve-se usar, ao invés do espaço em branco, uma sequência de celas com o ponto $3(\vdots \vdots)$, como ilustra a figura 2.18 .

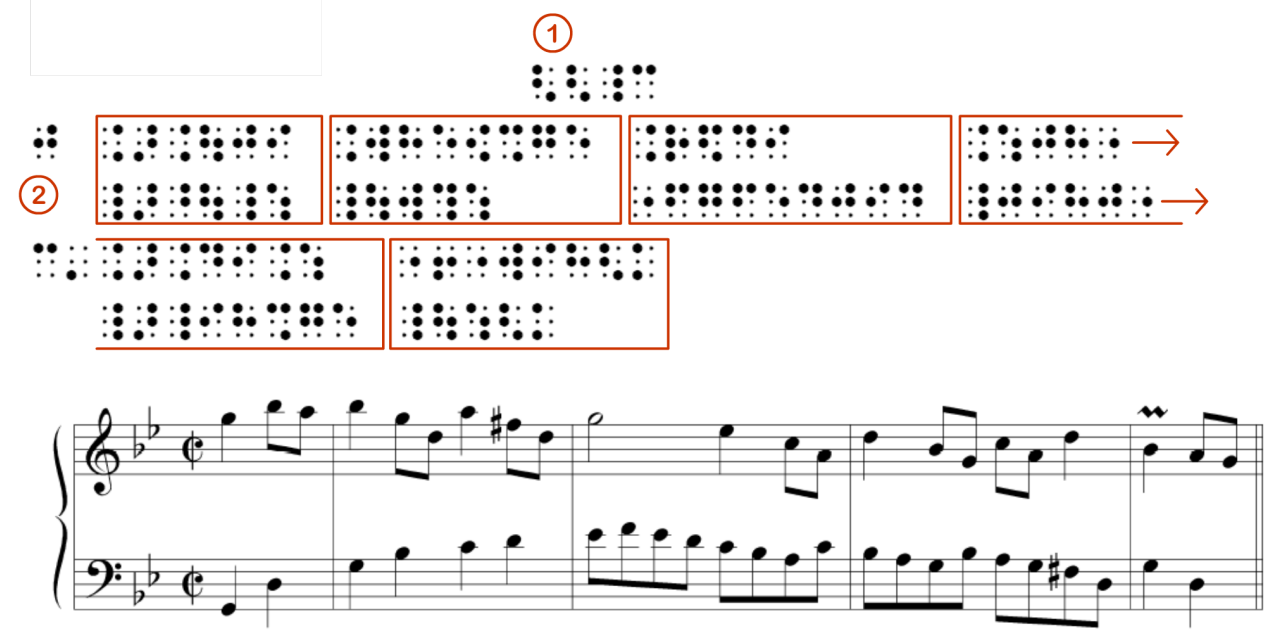

Figura 2.17: Leiaute no formato compasso sobre compasso
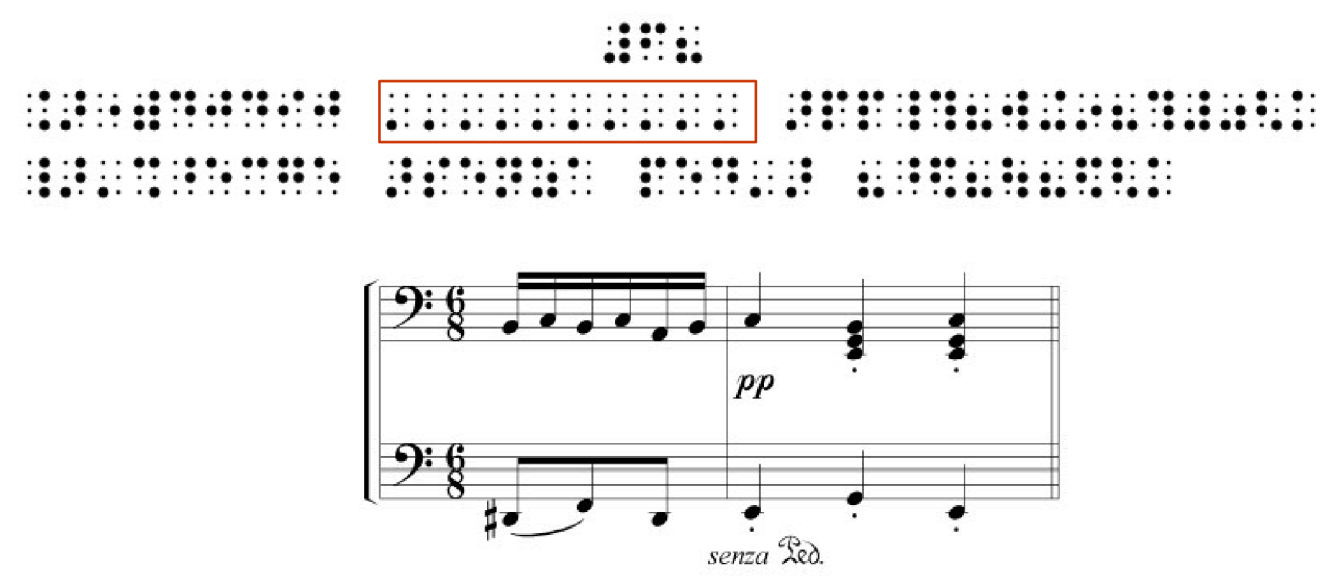

Figura 2.18: Separação de compassos pelo ponto 3

\section{Linha sobre linha (line over line)}

Este método difere-se do método compasso sobre compasso apenas em três aspectos:

1. A regra de alinhamento vertical dos compasssos não é aplicada

2. Não é necessário colocar marcas de oitava no início de cada compasso

3. A regularidade das paralelas pode ser interrompida quando um bloco possua indicações de repetições ou pausas correspondendo a mais de uma linha de música. 
Este método é exemplificado nas figuras 2.19 e 2.20. Na primeira figura, as linhas desenhadas sobre o trecho em braille evidenciam a irregularidade no início dos compassos. Na segunda figura temos um trecho um pouco maior, onde percebe-se que todo o primeiro conjunto de linhas (destacado com a cor vermelha) refere-se aos compassos unicamente do pentagrama marcado com clave de sol (em braille, identificado pelo sinal de mão direita); o segundo trecho, destacado com a cor azul, representa os compassos do pentagrama com clave de fá, onde ocorre um ostinato, o qual na representação em braille, por conta de símbolos que determinam a repetição do trecho, acaba tornando-se extremamente econômico. Neste caso em particular percebemos que este método de diagramação, dada a grande diferença de tamanho dos blocos, representa o trecho de forma mais econômica do que no formato compasso sobre compasso, onde haveria a necessidade de reproduzir por notas todo o ostinato e utilizar muitos trechos de espera para sincronizar verticalmente o início dos compassos. É também interessante perceber que este método permite que uma pessoa, utilizando a máquina Perkins, escreva um trecho musical com maior fluência do que se precisar concentrar-se com a contagem prévia da quantidade de celas envolvidas em todas as linhas para um determinado compasso.

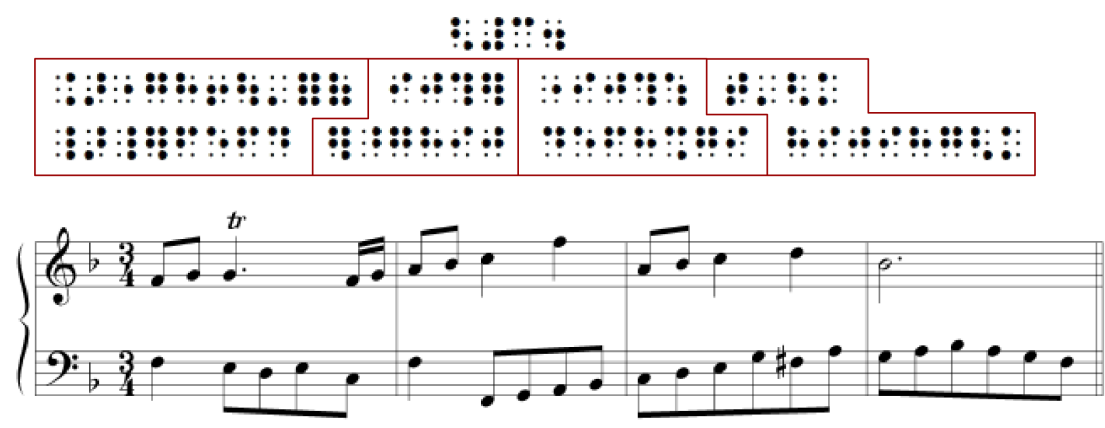

Figura 2.19: Método linha sobre linha: irregularidade no início dos compassos.

\section{Seção por seção ( section by section)}

Neste método de diagramação, as partes (de mão direita, de mão esquerda, pedais) são dispostos sequencialmente para um número arbitrário de compassos. O sinal de indicação de mão deverá situar-se à esquerda do início de cada parte; linhas subsequentes da mesma parte deverão sofrer indentação de dois espaços, mantendo alinhamento com o início do conteúdo musical da primeira linha, conforme ilustra a figura 2.21.

Se os compassos, na versão em tinta da partitura, forem numerados, esses números devem ser reproduzidos entre os compassos, separados dos mesmos com um espaço em branco de cada lado.

Antes do início de cada seção deverá haver uma linha de cabeçalho informando o número desta seção, quais os compassos nela representados, o número da página e o número dos pentagramas (na versão em tinta) aos quais a seção faz referência.

Segundo Bonilha (2005), neste formato cabe ao transcritor decidir o número de compassos de cada seção. O tamanho de cada uma delas varia conforme o critério estabelecido pelo profissional. Ele necessita analisar a peça, do ponto de vista de sua estrutura, no intuito de dividi-la adequadamente. A autora ainda fala da conveniência deste formato quanto à economia de papel, embora nele também seja mais difícil localizar rapidamente compassos por sua numeração.

\section{Partitura vertical (vertical score)}

Neste método, a partitura completa é representada verticalmente utilizando sinais de intervalos e "em-acordes", sendo a música lida sempre a partir das partes graves para as agudas. Este método 

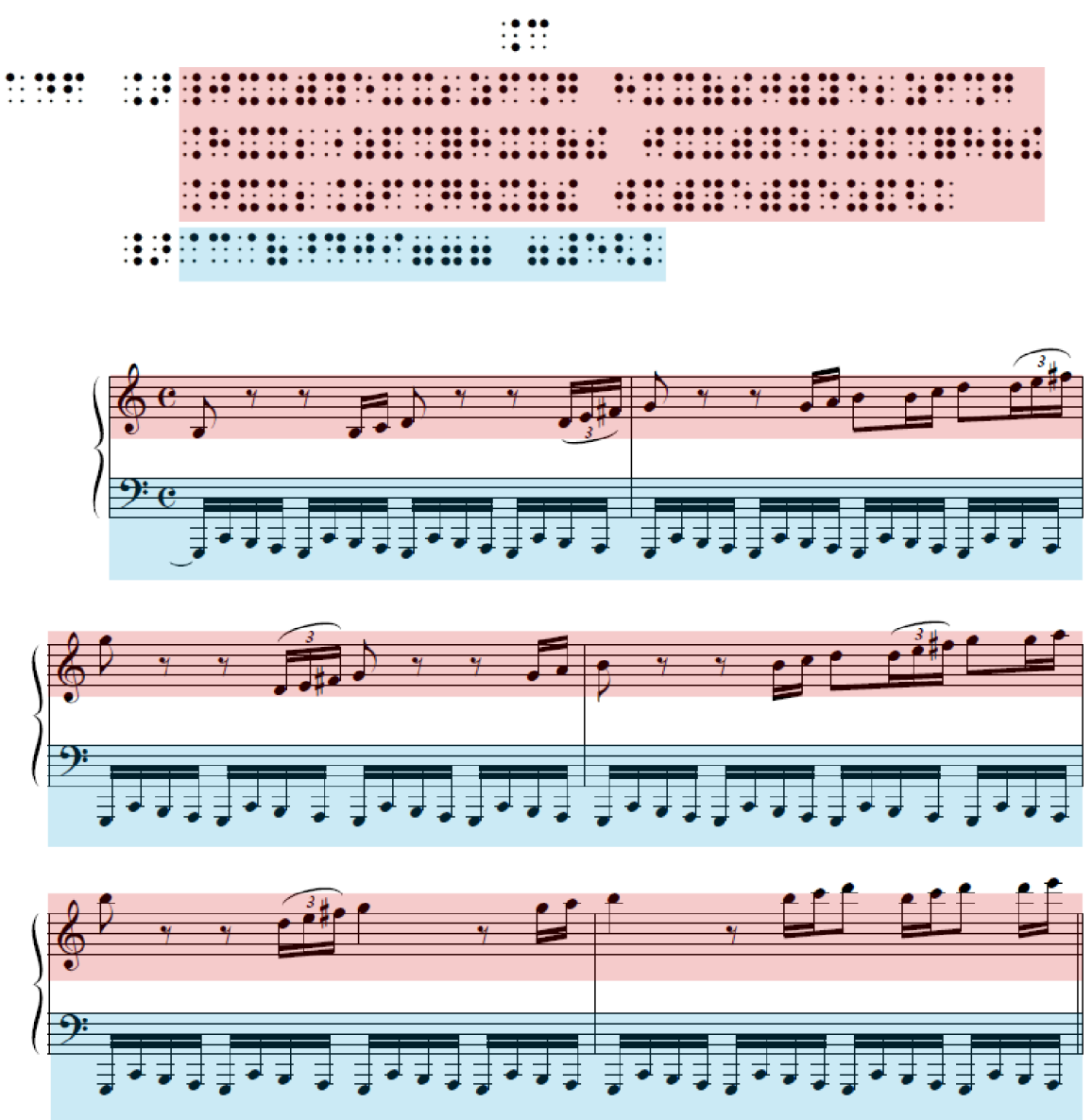

Figura 2.20: Método linha sobre linha: as linhas de um bloco podem ter tamanhos diferentes.

assemelha-se à redução de uma partitura em tinta, sendo útil para a compreensão harmônica de uma peça polifônica, sendo também usada para acompanhamento ao piano de peças para canto coral. Na figura 2.22 temos um excerto musical escrito utilizando este método. As duas versões estão divididas em três blocos, por onde é possível perceber que ambas as claves da versão em tinta estão sendo representadas, na versão em braille, em uma mesma linha.

\subsection{Conclusão do capítulo}

Este capítulo teve como objetivo principal introduzir o leitor às especificidades da musicografia braille, procurando mostrar elementos característicos desta linguagem, bem como os símbolos de seu alfabeto, buscando relacioná-los com a linguagem musical escrita tradicional. Também foi objetivo buscar uma abordagem sistemática para entender os indicadores de mudanças (de contexto e de valores) e sua relação com os próprios elementos musicais. 
::i::::
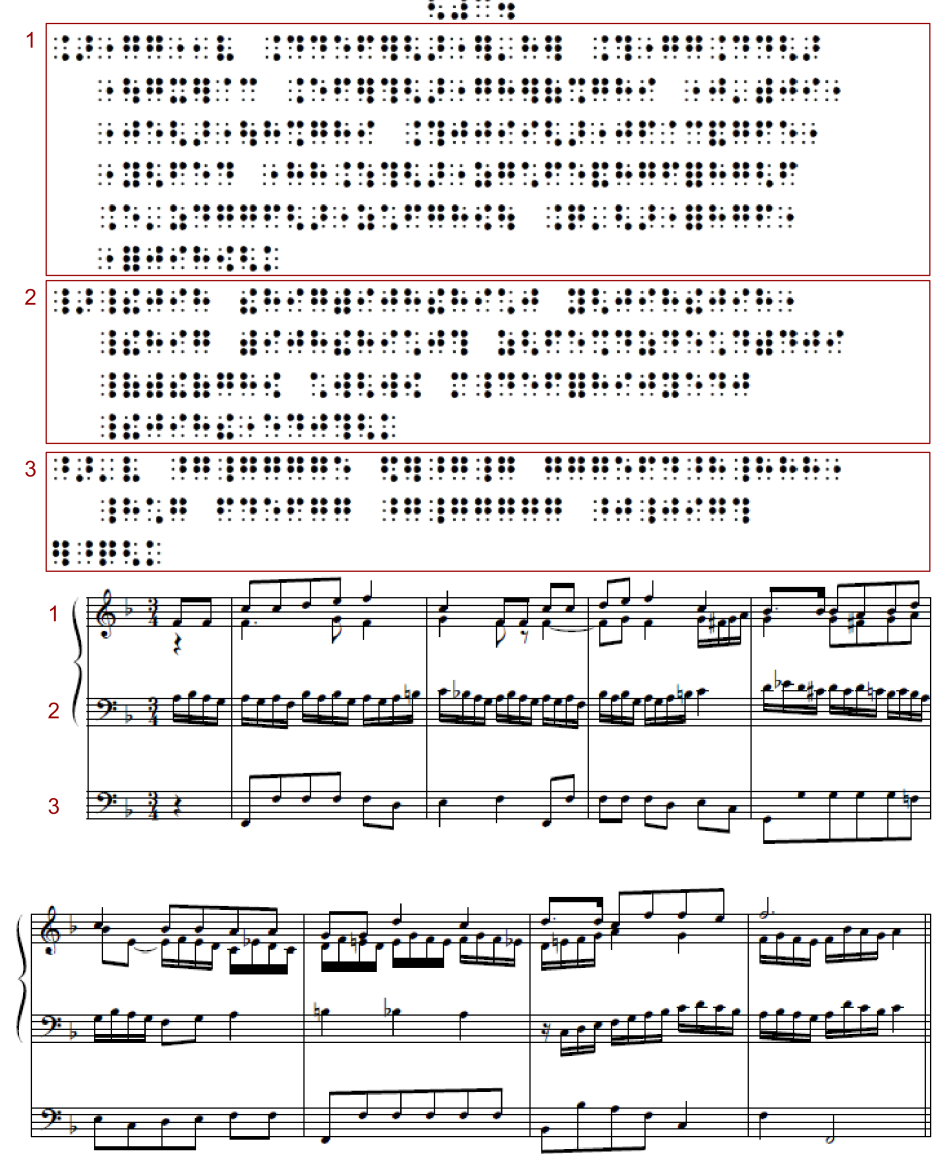

Figura 2.21: Método seção por seção

\section{$\because: 0: 0$}

:

:

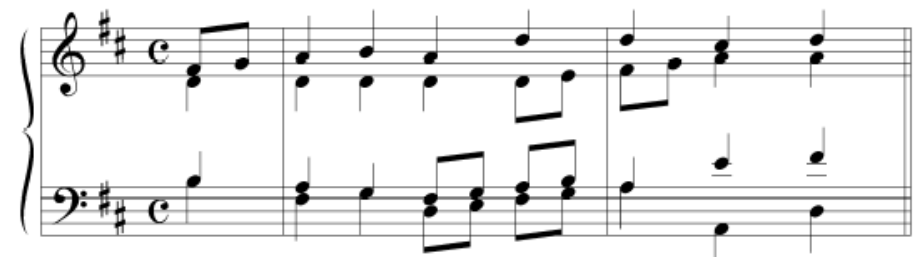

Figura 2.22: Método partitura vertical 


\section{Capítulo 3}

\section{Arquitetura do aplicativo}

O presente capítulo apresenta a arquitetura do aplicativo, detalhando os procedimentos adotados e os componentes utilizados para sua concepção, baseado nos requisitos iniciais. Serão investigados estudos anteriormente publicados que tratam do desenvolvimento de aplicativos para notação musical, buscando adaptá-los às necessidades específicas do objeto de estudo em questão.

A linguagem escolhida para desenvolvimento foi o Java, inicialmente por questões de portabilidade. Ademais, a comunidade de desenvolvedores adeptos à linguagem e ao conceito de software livre é grande, facilitando assim qualquer futuro manuseio do aplicativo. Durante o desenvolvimento, porém, verificou-se certas peculiaridades com relação a essa linguagem no que diz respeito à criação de interface gráfica acessível, conforme será detalhado na seção 3.1 .

\subsection{Interface do Usuário e Acessibilidade}

\section{Leitores de tela e interfaces gráficas em Java}

A interface gráfica é um objeto de estudo bastante peculiar neste trabalho. Embora o caráter estético do programa desenvolvido não seja a principal preocupação, a interface gráfica acaba sendo um problema bastante maior do que o esperado. Num primeiro instante, este problema está relacionado não à apresentação do conteúdo em si, mas à interpretação do que é efetivamente exibido em tela e o que é transmitido ao usuário cego por meio dos programas auxiliares leitores de tela. Isso ocorre porque o programa leitor de tela, sem perda de generalidade, é reativo unicamente às informações produzidas em tela, não sendo possível enviar ao mesmo solicitações de fala por outras vias mais diretas. Durante o desenvolvimento do Delius, muitas dificuldades foram encontradas com relação a este tópico, que serão pormenorizadas nesta seção.

Os programas de leitura de tela trabalham, via de regra, em baixo nível, interceptando o teclado e a informação que é produzida originariamente para os dispositivos gráficos, reproduzindo tais informações em áudio a partir de heurísticas próprias do aplicativo; são preparados para entender os componentes comuns das interfaces gráficas (botões, listas, campos de texto, etiquetas) e produzir com isso uma resposta sonora que possa prover a devida assistência, informando qual o tipo do componente de tela que está em foco e também sobre seu mecanismo de uso. Isso significa que programas que utilizam componentes de tela comuns e uma navegação coerente entre eles por comandos de teclado geralmente obtêm bons resultados de interpretação por parte destes programas. Para o desenvolvimento de componentes personalizados, porém, é necessário que se implemente métodos descritivos através de interfaces adequadas, mas na prática isso não garante que o resultado será sempre satisfatório, por conta dos motivos apresentados a seguir.

Em primeiro lugar, não há um modo único de produzir uma janela em tela - e, como dito acima, 
leitores de tela dependem da produção das janelas para terem algo de onde extrair informações. Entre outros, destaca-se no Java as interfaces gráficas AWT, Swing e SWT, todas elas com objetos e propriedades particulares - e para cada caso, os leitores de tela devem dispor de rotinas específicas de interpretação.

Em segundo lugar, existe uma variedade de programas leitores de tela e não necessariamente eles funcionam em mais de um sistema operacional. Nos sistemas baseados em Linux o leitor de tela mais comumente utilizado é o ORCA. No Windows, porém, os usuários dividem-se entre alguns principais leitores como o JAWS, o Virtual Vision e o NVDA, sendo apenas este último gratuito.

Os problemas aqui apresentados têm sido importantes não só para a escolha da interface gráfica mais adequada para utilização pelo Delius como também para levantar a seguinte questão: "o que há, atualmente, que estabeleça uma relação entre programas e usuários, que não dependa exclusivamente da concepção gráfica da informação?" ou, sob outra ótica, "por que os programas leitores de tela são efetivamente leitores de tela, havendo portanto uma dependência hierárquica do que é produzido em tela e, portanto, não se dando equivalente importância às diversas formas de saída da informação?".

De fato, estudos recentes buscam soluções mais elegantes do que a mera tradução do conteúdo visual em tela para áudio. Os projetos GUIB e Mercator (Mynatt e Weber, 1994), por exemplo, adotam como caminho a reinterpretação dos controles gráficos para produção de uma interface não-gráfica. O projeto GUIB ( Textual and Graphical User Interfaces for Blind People) se propõe a converter o resultado gráfico em telas produzidas pelo MS-Windows e X Windows em um dispositivo tátil, reproduzindo fisicamente o posicionamento espacial dos elementos da interface gráfica. $\mathrm{O}$ projeto Mercator faz uso de uma abordagem diferente, não exigindo dispositivos físicos específicos, apenas reinterpretando os controles e criando uma nova interface baseada em áudio para interação com o usuário; todo o controle de navegação e hierarquias entre os componentes é mediado pela ferramenta. Ambos os projetos, embora bastante diferentes, atualmente compartilham dos mesmos desafios, como garantir coerência e equivalência entre as interfaces gráficas e não-gráficas. Van Hees e Engelen (2010) propõe o conceito de interfaces abstratas, que possam ser renderizadas pelos toolkits de produção de telas (GTK+, ATK, etc) e paralelamente possam ser tratados de maneira diferente por interpretadores sonoros ou táteis. Tais projetos podem, futuramente, criar uma forma de se produzir interfaces acessíveis de forma mais definitiva e sensata.

Segundo Andrews (2010), o Swing é o renderizador gráfico mais preparado para a concepção de interfaces acessíveis. Esta ainda diz que os procedimentos principais para estabelecer uma comunicação com os leitores de tela são, em primeiro lugar, criar classes que extendam as classes JFrame e JPanel implementando, adicionalmente, a interface Accessible do Java Accessibility API (Sun Microsystems Inc). Após isso, configura-se os parâmetros disponíveis na propriedade AccessibleContext destas classes. Para que a informação alcance o leitor de tela, porém, é necessário que cada sistema operacional esteja preparado de algum modo para recebê-la do Swing. No caso dos sistemas operacionais da família Windows, a Oracle exige a instalação do componente "Java Access Bridge" que é responsável por interceptar, em um nível mais baixo, as ações do usuário e orquestrá-las juntamente com o programa de leitura de tela que estiver em uso. O Swing, no entanto, é apenas uma das ferramentas de produção de interfaces disponíveis no Java, dividindo espaço também com o SWT e o AWT, entre alguns outros menos expressivos.

O recurso gráfico SWT foi originalmente concebido pela IBM e hoje em dia é mantido pelo projeto Eclipse. Ele utiliza o GTK+ para produção visual da tela. Por padrão, ele produz janelas com o mesmo visual e comportamento das outras janelas de cada sistema operacional, pois interage diretamente com este para solicitar as renderizações. Em testes preliminares, esta interação direta mostrou-se vantajosa e as telas foram lidas corretamente pelos leitores JAWS e NVDA. 
O AWT é o processador de janelas mais antigo da Sun. São componentes bastante simples, e sua comunicação com os leitores de tela ocorre apenas pela leitura de um campo de descrição, uma vez que o AWT não implementa nenhuma interface de acessibilidade que contenha métodos próprios para esta tarefa. Os componentes Swing são, geralmente, extensões dos componentes AWT.

Relacionando estes problemas acima, do modo de produzir telas e janelas - dada uma combinação de determinada linguagem em algum sistema operacional - com o modo de interpretar o recurso criado - dada uma combinação de sistema operacional e ferramenta leitora de tela, o resultado é uma heterogeneidade bastante grande que se mostra, para estes fins específicos, pouco producente. Talvez isso ainda justifique, pelo menos parcialmente, porque tantos softwares baseados em janelas se mostram insatisfatoriamente acessíveis: ainda é difícil e custoso hoje, para uma equipe de desenvolvedores, produzir programas cuja acessibilidade seja plenamente satisfatória.

\section{Desenvolvimento da interface gráfica do Delius}

O estudo e implementação da interface gráfica mais adequada para o Delius passou por diversas fases por conta de uma série de barreiras e dificuldades. Um dos principais problemas enfrentados foi a escolha do recurso gráfico que seria utilizado. Embora, como já dito nos parágrafos acima, todos os componentes de produção de telas e controles se mostrassem potencialmente capazes de interagir com o leitor de tela, cada um tem suas exigências próprias de requisitos de instalação e dependências, mas os pontos mais críticos observados são (1) a não-padronização, em diversos aspectos, das apresentações visuais das interfaces gráficas, sobretudo buscando conformidade com requisitos de acessibilidade e (2) as diferenças entre os resultados audíveis destas apresentações visuais processadas pelos leitores de tela.

Testes preliminares foram realizados buscando identificar possíveis diferenças no tratamento gráfico e sonoro das interfaces gráficas. Num primeiro momento, verificou-se que o Swing e o SWT tinham bom relacionamento com os leitores de tela, desde que as exigências de dependências fossem atendidas. A descrição dos componentes gráficos produzidos com AWT ocorria em algumas situações apenas, não sendo possível garantir o funcionamento adequado em qualquer configuração.

O modo de alto-contraste, geralmente disponibilizado pelos sistemas operacionais, é um recurso de grande importância para este projeto, e também foi alvo de uma avaliação prévia. Concluiu-se que o SWT responde de forma eficaz, alterando as cores das janelas e componentes, bem como o tamanho das letras, de acordo com o padrão definido nas configurações de acessibilidade dos sistemas operacionais onde o teste foi realizado. O Swing, inicialmente, não obteve bons resultados; posteriormente verificou-se que o recurso de look-and-feel deste componente, responsável por promover uma plasticidade visual e criação de leiautes bastante ricos, é um potencial vilão com relação à acessibilidade. Constatou-se que o problema jazia na utilização de cores "fixas" ao invés da predileção por cores de sistema ${ }^{1}$, que são alteradas quando aciona-se o recurso de alto-contraste. Após certas adaptações a interface desenvolvida com Swing passou a responder também da forma adequada.

Constatou-se que ambas as interfaces Swing e SWT seriam adequadas para o desenvolvimento de aplicativos que utilizam em sua totalidade os componentes gráficos tradicionais, como botões, campos de texto e caixas de listagem. Para o desenvolvimento do Delius, porém, a possibilidade de criação de componentes próprios, para fins específicos, é bastante desejada, pois é necessário representar música na forma gráfica tradicional e em braille. O desenvolvimento de controles personalizados e acessíveis em Swing se mostrou muito mais prático do que utilizando SWT, motivo esse que culminou na decisão de uso do Swing. As questões de acessibilidade destes componentes perso-

\footnotetext{
${ }^{1}$ classe SystemColor do pacote java.awt.System Color do Java
} 
nalizados, porém, ainda trouxeram outros problemas, pois era difícil controlar a mensagem reproduzida pelo leitor de tela ${ }^{2}$; basicamente, a criação de um novo componente acessível demanda que se especifique certos atributos de acessibilidade, como o nome descrição acessíveis (accessibleName e accessibleDescription). No entanto, isso não garante a forma como o leitor de tela irá tratar essa informação. Um outro atributo informa ao leitor de tela o "papel" (accessibleRole) do componente, e é com base nele que o leitor vai formar sua descrição completa, por exemplo informando, no caso de uma lista, qual é o elemento atualmente selecionado e quantos outros elementos existem nela. O leitor de tela utilizado, porém, tinha um comportamento já definido para estes "papéis" tradicionais de componentes, e nenhum tratamento para novos papéis. Isso quer dizer que um componente que representa uma cela braille não poderia ser lido como tal. Constatou-se, finalmente, que alguns dos "papéis" entendidos pelo leitor de tela, como por exemplo o de "item de menu", produziam como resposta sonora apenas o nome acessível do componente, e pôde portanto ser utilizado para dar ao usuário, via leitor de tela, uma resposta minimamente controlada.

Numa primeira abordagem, na tentativa de se ter ainda um bom controle das mensagens sonoras que seriam enviadas ao usuário, buscou-se adotar uma estratégia de eleger um único componente visual com foco (uma etiqueta, neste caso), onde as mensagens seriam produzidas e dali enviadas para o usuário. Dessa forma, todo foco dado aos componentes não-tradicionais (uma nota musical, por exemplo) produziriam uma nova mensagem nesta etiqueta, que em seguida receberia foco e dispararia a mensagem. Essa estratégia é uma sugestão de Bannick (2011), que enumera uma série de técnicas para desenvolvimento de jogos para pessoas cegas, possuindo informações bastante enriquecedoras no que diz respeito à interação com o jogo por meio de teclado e pela resposta unicamente sonora, e portanto inspirador para o problema deste caso específico onde há demanda de novos componentes gráficos. Esta primeira abordagem acabou não se mostrando adequada por problemas com o controle do componente em foco, onde dependendo da configuração (de sistema operacional e leitor de tela utilizado) as alterações dinâmicas no componente responsável pela interação com o leitor não produziam nenhum efeito.

Buscando as características comuns entre leitores de tela foi possível, finalmente, encontrar uma solução segura de interação com estas ferramentas. Verificou-se que a mudança de foco de um componente para outro, desde que o papel (accessibleRole) de ambos seja previamente "conhecido" pelo leitor de tela, produzia resultado sonoro. Solicitar foco para um componente que já estava em foco produzia resultado sonoro em alguns casos apenas - invalidando portanto a primeira abordagem supracitada. A solução, portanto, seria produzir um componente para cada elemento do programa que, durante a navegação do usuário, necessitasse ser descrito pelo leitor de tela.

$\mathrm{O}$ aninhamento das estruturas musicais dentro de um componente de árvore foi uma primeira estratégia adotada dentro deste princípio, que embora produzisse um resultado de interação com o leitor de tela a contento, produzia uma certa confusão visual. Buscou-se então desenvolvimento de um componente mais compacto onde todos os níveis da estrutura simbólica musical pudessem ser visualmente bem representados sem interferir na navegação esperada. Maiores detalhes do método de navegação do usuário estão presentes na seção 3.2.

Adicionalmente, todos os componentes gráficos criados utilizam predominantemente cores de sistema, de forma que os ajustes específicos de alto contraste, fundamental para portadores de baixa-visão, sejam refletidos na representação visual destes componentes.

\footnotetext{
${ }^{2}$ Durante o desenvolvimento do programa o leitor de tela NVDA foi utilizado predominantemente.
} 


\subsection{Entrada de Dados e Navegação}

Já foi mencionado anteriormente que, diferentemente da maioria dos programas de grafia musical, é esperado que este programa seja utilizado por pessoas sem nenhuma acuidade visual, não podendo depender de referências gráficas no monitor para localização das informações, tampouco do uso do ponteiro do mouse para seleção de objetos ou para entrada de dados. Tratando-se de documentos musicais, é também importante encontrar uma maneira de permitir que o usuário navegue com eficiência entre os elementos musicais.

Estabelecendo uma relação com outros tipos de documento, fica bastante claro o caráter específico do tipo de navegação exigida para o aplicativo em questão. A navegação entre documentos de texto (utilizando um processador de textos ou um navegador para internet), por exemplo, é geralmente mediada pelos leitores de tela, que fornecem ao usuário alguns atalhos de teclado que o permitem caminhar de parágrafo a parágrafo, palavra a palavra, letra a letra. Além disso, tais recursos também podem fazer um resumo dos cabeçalhos presentes no texto e trazer essa informação ao usuário em forma de uma lista de escolha, criando com isso um acesso à informação mais categorizado e dinâmico.

Na presente situação, é desejável que o usuário possa caminhar entre os elementos musicais também de forma categorizada. Mais do que isso, para que seja possível reconhecer corretamente os sinais braille produzidos pelo usuário, é fundamental conduzir o usuário corretamente às posições no documento onde tal produção se faz possível, considerando que o entendimento dos sinais braille depende do contexto no qual eles são inseridos.

A seção 4.3 detalha a estruturação da informação musical de forma hierárquica, forma esta que é utilizada também para conduzir a navegação do usuário dentro da partitura digital produzida no Delius. Essa forma de estruturação implementa o padrão de projeto Composite; este padrão permite que objetos sejam compostos em estruturas de árvores para representar hierarquias do tipo parte-todo (Eric Freeman, 2004), possibilitando que objetos sejam tratados pelos programas tanto como coleções quanto como objetos individuais. Além disso, esta estrutura pode ser eficientemente representada, na interface com o usuário, por um componente de navegação em árvore que permita que o usuário interaja coerentemente com o modelo de representação.

A navegação do usuário nessa estrutura é realizada através do componente gráfico personalizado JBrailleMusicNavigator, que permite uma navegação por contextos semelhante à do componente JTree. A criação deste componente ocorreu pela necessidade de controle da saída sonora produzida pelos leitores de tela: em testes preliminares utilizando o componente JTree, tanto o NVDA como o JAWS, por padrão, verbalizavam uma série de informações desnecessárias (nome do elemento contêiner, número de nós na árvore) que atrapalhavam a experiência do usuário. Em outras tentativas, buscou-se interceptar os comandos de navegação externamente e produzir a informação acessível em outro componente, produzindo no componente gráfico de árvore apenas o efeito visual correspondente. Esta experiência também não foi bem-sucedida, pois o ato de modificar o foco dos nós da árvore forçavam indesejadamente que os leitores de tela fizessem a leitura do componente de árvore.

Envolvidos em problemas semelhantes, Smith et al. (2004) propõe um modelo de componente em árvore acessível, onde certos requisitos funcionais são adicionados, como comandos para localização imediata dentro da estrutura, comandos de movimentação entre nós primos, recursos como "marcadores de página" (memorizando posições na estrutura e recuperando o acesso a qualquer momento), entre outros. Este estudo inspirou o desenho deste componente, e algumas das funcionalidades propostas, pertinentes à situação em questão, também foram adicionadas.

Esta estrutura em árvore intercepta os comandos do teclado e mouse para realizar a navegação, embora a utilização de mouse seja perfeitamente dispensável para a operação do componente. A 
classe StructureNavigator é responsável por interpretar estas ações do usuário, efetuadas no componente gráfico JBrailleMusicNavigator, solicitando ao controlador principal que realize a navegação e notifique todos os observadores sobre a alteração realizada. A classe StructureNavigator estende a classe abstrata AbstractNavigator, cuja principal função é comunicar-se com o controlador principal por meio de métodos próprios para navegação, conforme mostra o diagrama de classes da figura 3.5. Dessa forma, é possível ampliar o programa com novas formas de navegação pelo teclado criando-se novas extensões da classe AbstractNavigator.

Com as setas para cima e para baixo, o usuário navegará verticalmente na árvore, isto é, aprofundando-se em elementos mais específicos existentes dentro do elemento corrente ou navegando para blocos maiores e mais genéricos. Com as setas da esquerda e da direita, o usuário caminhará horizontalmente nos nós irmãos a partir de um mesmo nó pai, podendo caminhar assim de instrumento a instrumento, compasso a compasso ou varrer cada elemento contido em um compasso. Pressionando a tecla Shift enquanto navega pelas setas, o usuário poderá navegar do compasso $\mathrm{N}$ de um instrumento ao mesmo compasso $\mathrm{N}$ de outro instrumento; essa forma de navegação é provavelmente tão importante quanto a primeira se o usuário estiver, por exemplo, criando um arranjo de vozes.

Para cada elemento acessado pelo usuário, o sistema informará sua posição. Dentro de cada elemento o usuário sempre terá a possibilidades de dar os comandos indicados na tabela 3.2.

\begin{tabular}{|c|l|}
\hline Comando & Funcionalidade \\
\hline \hline Setas direcionais verticais & Navega entre os nós pais e filhos \\
Setas direcionais horizontais & Navega entre os nós irmãos \\
Shift + Setas direcionais horizontais & Navega entre os nós primos \\
I & Acessa o menu do contexto atual \\
Ctrl + O & Descreve o contexto atual \\
P & Toca o elemento em foco \\
Shift+P & Toca o contexto-pai do elemento em foco \\
\hline F1 & Ajuda \\
F2 & Modo de navegação pelo documento \\
F3 & Modo de navegação musical \\
F4 & Modo de listagem de erros \\
\hline F9-F12 & Marca-páginas \\
Shift + (F9-F12) & Retornar às posições marcadas \\
\hline F,D,S,J,K,L & Teclado braille emulado. \\
Espaço & Quebra de compasso / cela braille vazia \\
Backspace, Del & Remoção do último elemento \\
Ctrl+Z & Desfaz a última ação \\
\hline
\end{tabular}

Tabela 3.1: Teclas de acesso às funcionalidades do programa

\section{Simulação da máquina braille}

No contexto de compasso, o usuário terá disponível a opção de entrar com informações musicais utilizando um emulador de teclado Perkins (ver seção 2.2), simulando o funcionamento dessa máquina no próprio teclado do computador. Este usuário fará uso das teclas F, D, S, J, K e L ${ }^{3}$ para "puncionar" os pontos das celas, a tecla SPACE (barra de espaço) e BACKSPACE para avançar e

\footnotetext{
${ }^{3}$ É comum que teclados de computador venham com pequenas marcas embaixo das teclas "F" e "J", inclusive dando à mão o formato anatômico equivalente das máquinas Perkins, e por esse motivo essas teclas foram determinadas, neste aplicativo, para esse fim.
} 
retroceder o carro e ENTER para pular linha.

Nas experiências preliminares do aplicativo foram verificados problemas quanto à emulação de teclado Perkins em alguns teclados convencionais de computador. Alguns modelos deste dispositivo apresentavam-se incapazes de responder à pressão simultânea de múltiplas teclas. Trata-se da maneira como é fabricada a matriz de teclas de cada dispositivo; dependendo do projeto, a pressão simultânea de determinadas teclas pode levar a um fenômeno de mascaramento de novas entradas que é comumente chamado de ghosting ${ }^{4}$. Coletando informações de usuários, percebeu-se que este fenômeno é mais frequente nos teclados de computadores portáteis. Muitos teclados convencionais, com fio, entrada USB e sem identificação de fabricante foram submetidos a um rápido teste e apresentaram resultados satisfatórios. O teste consiste em abrir qualquer programa de edição de texto e pressinar simultaneamente as teclas usadas pelo teclado braille: $\mathrm{f}, \mathrm{d}, \mathrm{s}, \mathrm{j}, \mathrm{k}, \mathrm{l}$ e verificar se todas as teclas produziram resposta em texto ${ }^{5}$. Portanto, será importante notificar o usuário através da documentação do aplicativo que certos teclados (sobretudo os de computadores portáteis) não são adequados para este aplicativo, e que esse problema pode ser resolvido facilmente adquirindo algum teclado mais apropriado para esse fim específico.

\section{Tratamento de erros de entrada do usuário}

A representação musical pela partitura convencional faz parte da cultura ocidental há muitos séculos. Esta grafia atingiu uma maturidade que nos permite identificar a ocorrência de erros de grafia em obras musicais e sua provável correção de acordo com a real intenção do compositor.

A organização musical de uma partitura escrita a tinta nos fornece uma proposta de leitura; possíveis erros de grafia também estão relacionados com essa organização: é comum encontrarmos erros como notas estourando a capacidade do compasso quando, por exemplo, uma mancha do papel se faz passar por um ponto de uma nota pontuada. A experiência de uso da partitura convencional nos permite discernir tais situações levando em consideração os possíveis erros.

A musicografia braille tem como alicerce o enfileiramento sequencial das celas. Um engano em um único ponto de uma cela ou mesmo a omissão acidental de uma cela pode claramente conduzir o leitor a uma interpretação errônea da sentença ou mesmo torná-la incompreensível. Da mesma maneira, um erro de escrita dos pontos pode vir a produzir um resultado compreensível e válido, mas completamente diferente do desejado. É difícil imaginar, numa partitura em tinta, erros de grafia que resultem na criação não intencional de uma barra de repetição, um crescendo no lugar de um diminuendo ou até mesmo coisas mais grosseiras como descobrir que um sinal de pedalização de piano se fez passar por uma ligadura, ou que indicações de digitação do violão na verdade deveriam ser lidas como notas de um acorde. Erros dessa natureza, no entanto, são possíveis em braille, pela omissão ou acréscimo de celas ou pontos de forma não-intencional.

Para garantir a qualidade do conteúdo, portanto, certas verificações devem ser realizadas no momento da entrada da informação, enquanto outras devem ser aplicadas no momento da conversão. Isso significa que o programa deverá informar imediatamente após receber uma determinada entrada se ela é válida ou não e, em caso positivo, o que ela representa musicalmente, dando ao usuário a capacidade de corrigir naquele instante um possível erro. Em outro momento, ao solicitar a conversão, o programa pode informar ao usuário outros detalhes, como por exemplo que certos

\footnotetext{
${ }^{4}$ http://www.microsoft.com/appliedsciences/content/projects/AntiGhostingExplained.aspx

${ }^{5}$ Alguns teclados desenvolvidos com ênfase em jogos de computador, aplicativos estes que frequentemente requerem pressão simultânea de múltiplas teclas, apresentam o que chamam de tecnologia "anti-ghosting". Tal tecnologia garante combinações múltiplas apenas para determinados subconjuntos de teclas apenas (Microsoft Applied Sciences Group, 2010). Utilizando-se de uma tecnologia diferente, ela apresenta um teclado que possui capacidade de receber até 17 teclas simultâneas em qualquer combinação do teclado $Q W E R T Y$
} 
compassos possuem notas a mais ou a menos, ou que ligaduras de expressão abertas não foram fechadas corretamente.

A lista abaixo mostra os erros de produção atualmente informados ao usuário. Espera-se que, alcançando maior maturidade, o programa atenda a uma lista expressivamente maior de observações:

- Ausência de fórmula de compasso (considera-se $\frac{4}{4}$ )

- Falta de sinal de oitava (considera-se quarta oitava do braille)

- Ligadura de prolongamento entre notas de diferentes alturas

- Ligadura não possui uma nota inicial/final

- Cela ou grupo de celas não identificado

- Compasso $n$ não está completo

- Compasso $n$ não possui símbolo final (barra de compasso, barra dupla)

- Compasso $n$ possui mais de um símbolo final

\subsection{Disposição da informação musical em uma partitura braille}

Na seção 2.9 foram discutidas as diversas formas de apresentação da informação musical em braille e em que situações a aplicação destas formas é apropriada, com base na intenção de leitura do usuário, e sua necessidade de localização dentro do documento.

Pelo MIMB, particularmente na versão em inglês, as regras de formatação são em geral bastante claras, sendo possível transcrevê-las em heurísticas de auto-formatação, de forma que, meditante uma parametrização prévia, o documento final em braille possa ser diagramado automaticamente, tanto para exibição em tela quanto para impressão. Percebeu-se, porém, que esta prática é viável apenas na medida em que os aspectos musicais afastam-se dos aspectos gráficos ou de diagramação. Nos métodos definidos como "compasso sobre compasso" e "linha sobre linha" é possível utilizar toda a informação musical exatamente da maneira como ela está definida no modelo, complementando-a apenas com questões protocolares como a repetição de sinais de oitava para cada início de compasso, repetição dos sinais de mão a cada início de seção. Para estes casos não é necessário nenhum tipo de adaptação dos símbolos presentes no modelo para a saída final. No método definido como "partitura vertical", no entanto, a exibição da informação de forma verticalizada (usando sinais de intervalo e "em-acorde") requer uma reinterpretação do modelo e alteração simbólica: as melodias de vários instrumentos deveriam ser recodificadas. Este é um caso claro onde os aspectos simbólicomusicais estão fortemente relacionados com os aspectos de formatação ${ }^{6}$.

No pacote formatter há uma classe abstrata chamada AbstractFormatter que define o protocolo de entrada e saída para produção de um formato de exibição do material. Elas deverão receber, como entrada, o conteúdo musical de um objeto do tipo BrailleScore e o objeto do documento impresso, que é dividido em páginas, formadas por uma quantidade arbitrária de linhas e colunas. Este formatador deverá utilizar-se do modelo para produzir, neste conjunto de linhas e colunas, a saída necessária, acrescentando, omitindo, organizando e alinhando a informação musical, sem que

\footnotetext{
${ }^{6}$ Para este caso em particular, porém, não será criado nenhum conversor de formato no presente momento, por tratar-se de um um formato ainda não reconhecido oficialmente pelo comitê gestor da musicografia braille, constante apenas em apêndice do manual, mas neste caso em particular sua citação é importante para ilustrar as possíveis relações existentes entre os aspectos musicais e de formatação de documento, em braille.
} 
nenhuma alteração seja feita no modelo para tanto.

O usuário poderá, portanto, concentrar-se na produção do conteúdo musical ignorando, num primeiro momento, as questões de disposição do material no resultado impresso, então tratando tal aspecto isoladamente, podendo parametrizar e testar vários formatos diferentes, tarefa impraticável na produção de uma partitura utilizando a máquina Perkins.

Este recurso também é desejado para que se permita que o usuário possa, futuramente, extrair uma porção limitada de um documento completo, como um ou dois instrumentos apenas, podendo decidir para esta situação específica uma formatação mais adequada.

\subsection{Padrão de arquitetura utilizado}

A arquitetura sob a qual o Delius é construído baseia-se em uma variação do padrão Model-ViewController (MVC) (Eric Freeman, 2004; Krasner e Pope, 1988). Este é um padrão de arquitetura onde a interface de interação com o usuário (View) é totalmente separada do modelo de representação (Model), que por sua vez é responsável por garantir sua integridade. Todos os métodos que modificam seu estado estão contidos no próprio modelo. Adicionalmente, o controlador (Controller) é um terceiro elemento que compõe esta estrutura, e é responsável por "entender" a interação do usuário com o View e, baseado nisso, efetuar as alterações de estado do Model. A figura 3.1 ilustra a relação entre estas três estruturas do padrão de arquitetura MVC.

O Model comunica-se com as outras partes da estrutura através do disparo de eventos. Utilizase, portanto, o padrão de projeto Observer, criando uma interface com os métodos que devem ser chamados quando há alteração de estado do Model. As classes de interação com o usuário têm acesso ao modelo de representação para que possa ler seus atributos, mas não devem nunca chamar seus métodos diretamente. Devem, no entanto, disparar eventos que são recebidos pelas classes que compõem o Controller, que são hábeis para chamar os métodos que modificam o modelo de representação.

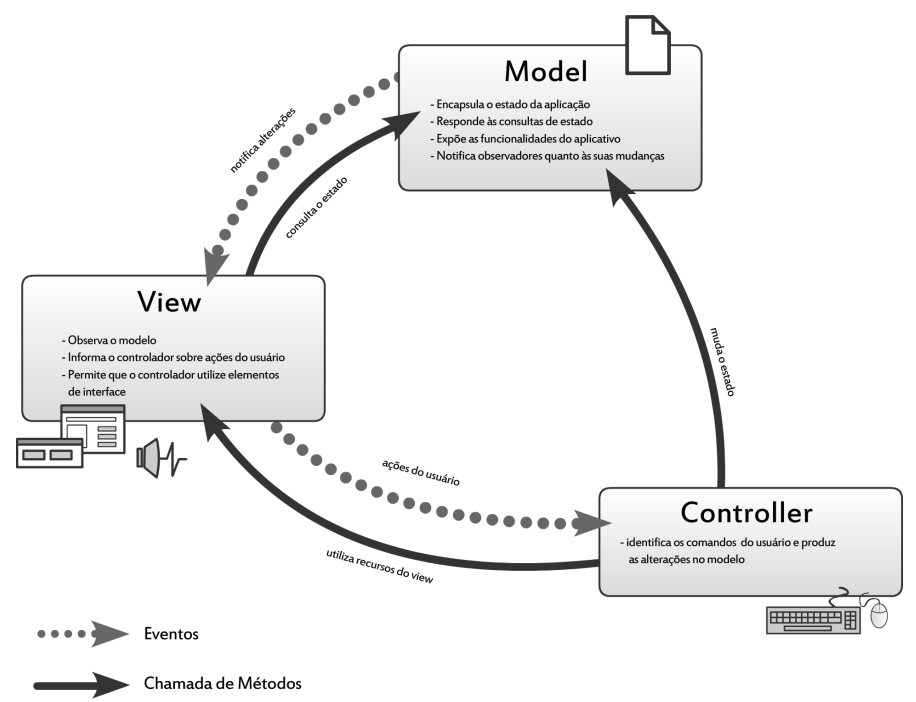

Figura 3.1: Diagrama da arquitetura Model-View-Controller (MVC)

Esta independência da camada lógica e de interação promovida pelo MVC traz diversos benefícios ao desenvolvimento deste aplicativo. Num primeiro momento, foi possível discutir o modelo de representação isoladamente (no capítulo 4), ainda que prevendo as interações desejáveis de se 
realizar com o usuário. Da mesma maneira, fica claro que as questões de acessibilidade relacionamse quase que em sua totalidade com a camada de interação; Durante a escolha da interface gráfica adequada levantou-se uma grande quantidade de problemas (seção 3.1), mas em momento algum o modelo de representação teve qualquer relação direta com eles.

A camada de controle traz também alguns benefícios que dão dinamismo ao programa. Talvez um dos benefícios mais importantes seja a possibilidade de trazer ao usuário menus com opções que são pertinentes aos contextos em foco; a camada de interação apenas deve informar o Controller sobre qual o contexto focado e este tem o conhecimento de quais opções devem ser informadas ao usuário. Da mesma maneira, é possível mudar o comportamento de atuação do usuário. Os modos de navegação no documento, apresentados na seção 3.2, alternam-se mediante tão somente a substituição do objeto, dentro do Controller, responsável por interceptar os comandos de teclado do usuário, sendo que cada objeto dá tratamento diferente para estes comandos. A figura 3.2 exemplifica como o programa intercepta a navegação do usuário diferentemente para cada modo.

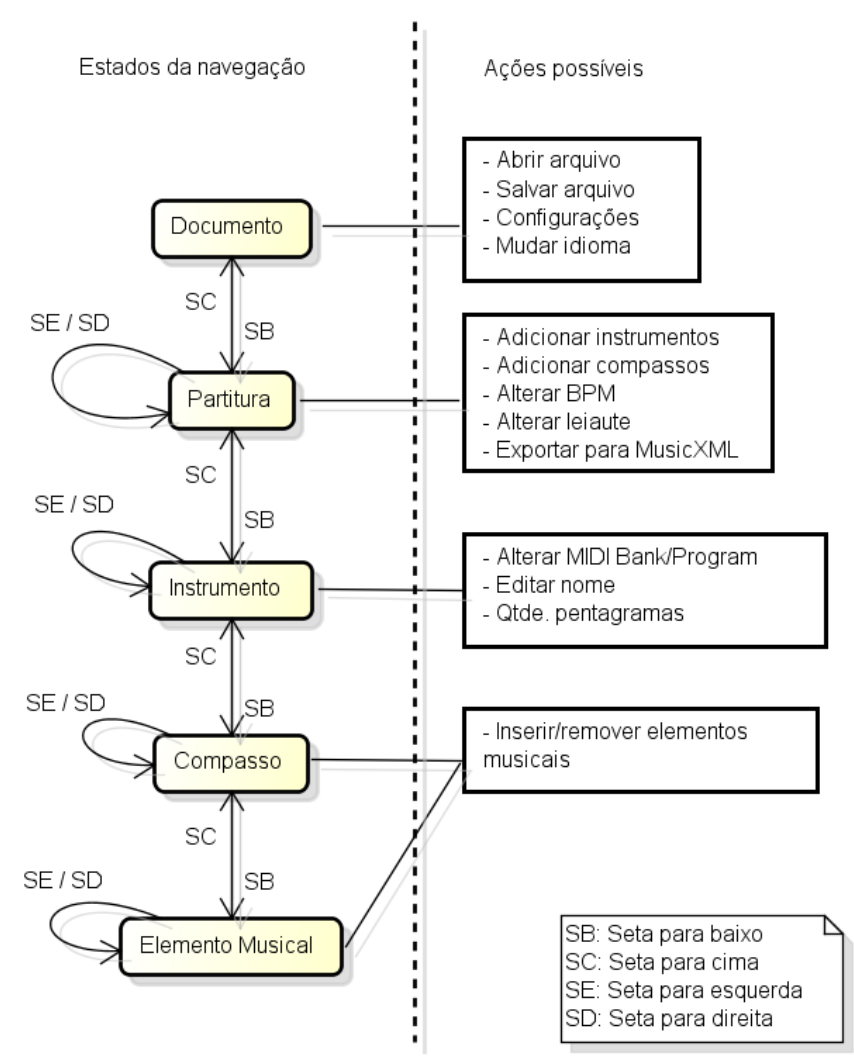

Figura 3.2: Diagrama de estados - Relação entre os estados de navegação e as possíveis ações do usuário

Um outro benefício da camada de controle é a possibilidade de acrescentar ao programa o recurso de desfazer ações (Undo). Para tanto, utiliza-se o padrão de projeto Command, onde os métodos do Model a serem chamados pelo Controller são encapsulados em pequenas classes que compartilham de um mesmo método de execução (método execute(), por exemplo). O Controller, ao invés de chamar os métodos diretamente, instancia uma dessas classes de comando e chama seu método de execução, que por sua vez contém os métodos que fazem alteração no modelo. Uma vez executados, o objeto de comando pode ser adicionado a uma pilha; mediante um comando do usuário, este objeto de comando pode ser desempilhado e um segundo método (undo()), responsável por reestabelecer o modelo em seu estado inicial, é executado.

Outra abordagem arquitetural utilizada regularmente é a conhecida por PAC - Presentation- 
Abstraction-Controller (Coutaz, 1987). Este padrão é semelhante ao MVC, porém com algumas diferenças bastante relevantes: as estruturas de dados contidas no que se define por Presentation e Abstraction nunca trocam informações diretamente, senão por meio do Controller. O padrão PAC, no entanto, introduz o conceito de que esta tríade (model-view-controller) não há de ser necessariamente uma estrutura única, podendo ser criados pequenos controles de tela que respondem a uma estrutura de apresentação, abstração e controle próprios. Dessa forma, cada pequeno controle tem autonomia em relação aos demais.

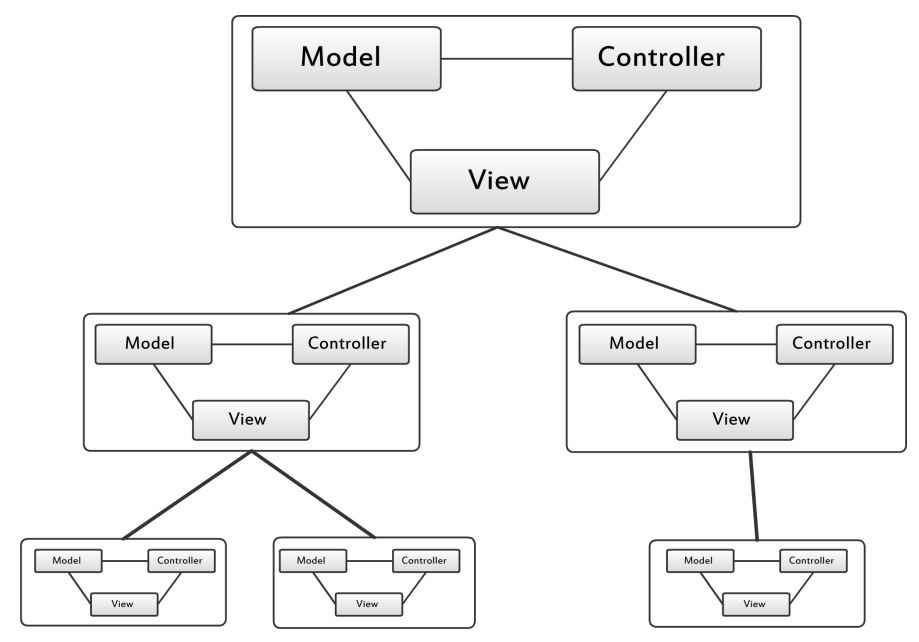

Figura 3.3: Representação do padrão arquitetural Hierarquical Model-View-Controller.

A variação utilizada pelo Delius é o Hierarquical Model-View-Controller (HMVC) (Cai et al., 2000), uma variação conciliadora dos dois padrões acima apresentados, onde aproveita-se o conceito de que os controles são composições individuais de modelo, visão e controle, cada um com certa autonomia em relação aos outros, e organizados hierarquicamente. Neste caso, a estrutura de controle não mais possui a quantidade excessiva de responsabilidades do MVC, e a comunicação por meio de eventos/observadores pode estender-se facilmente para além de cada tríade. A figura 3.3 exemplifica a organização das tríades que compõem o HMVC.

No caso do Delius, este padrão de arquitetura se mostra adequado por dois motivos principais: em primeiro lugar, a tela divide-se em vários componentes autônomos, responsáveis por representar a informação musical contida no documento sob diversos aspectos diferentes. Em segundo lugar, aproveita-se com isso a própria hierarquia das estruturas musicais presentes no modelo de representação, de forma que um componente pode entender como seu Model o modelo de representação como um todo ou apenas parte dele. A figura 3.4 mostra a relação entre os componentes gráficos e o padrão HMVC.

A figura 3.5 mostra uma parte das relações entre as entidades de controle e de visão dentro do sistema. A classe MainController é o principal controlador do programa. É responsável por interceptar as ações do usuário dentro do escopo da tela principal do programa, empilhar e executar os objetos de comando, gerenciar janelas de diálogo, entre outras coisas. Outras classes menores, dentro do pacote delius.controller, relacionam-se com funcionalidades mais específicas. Nesta mesma figura está representada a estrutura responsável pela navegação, mencionada na seção 3.2:

\section{Organizacão e Pacotes}

Até o presente momento, as classes responsáveis pela aplicação estão divididas e estruturadas da seguinte maneira: 


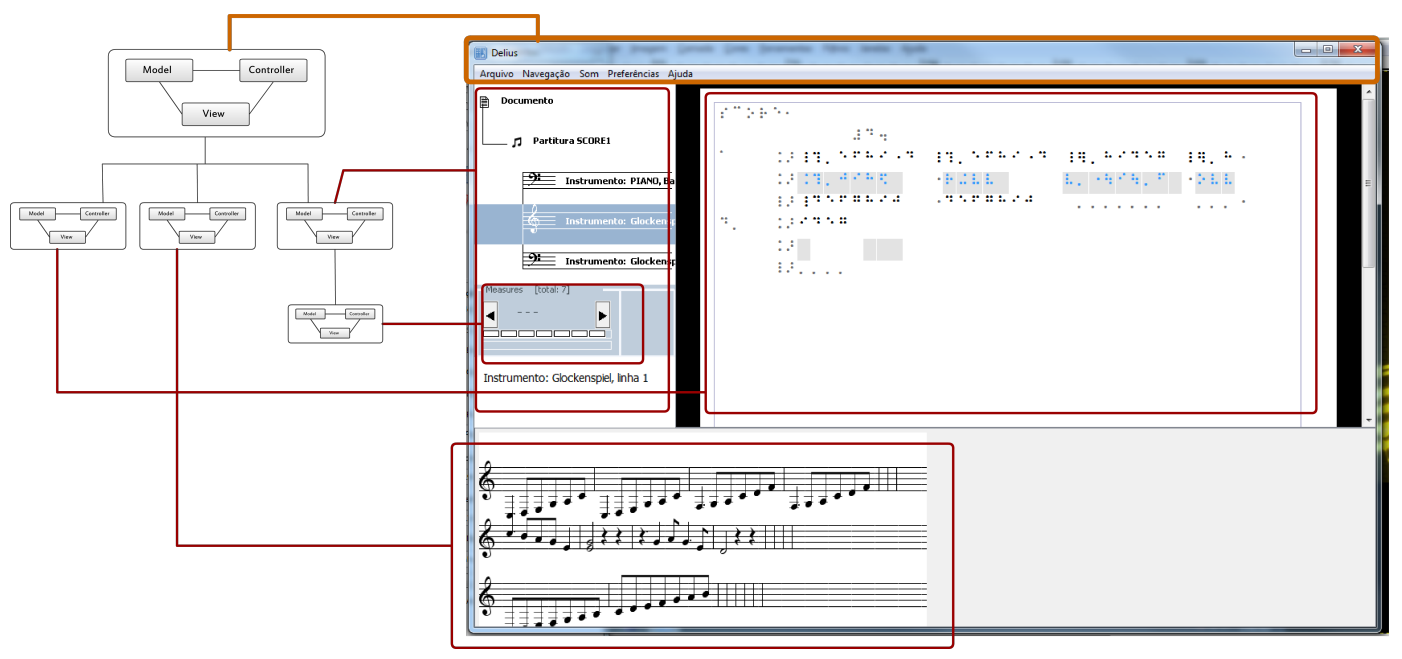

Figura 3.4: Componentes gráficos no Delius e sua organização hierárquica do HMVC

delius.main: É o ponto de partida da aplicação. Neste pacote encontra-se a classe Delius que implementa o método Main() para iniciar o programa. As classes aqui presentes são referentes às classes estruturais de maior importância.

delius.braille e delius.braille.music: Estes pacotes agrupam as classes utilizadas para manipular o código braille, onde estão contidas as classes Cell e CellSet, utilizadas para representar a escrita por pontos. Também contêm a classe responsável pela emulação do teclado Perkins. O pacote delius.braille.music possui extensões da classe CellSet que representam elementos definidos da musicografia braille, como instrumentos, compassos, notas, que são igualmente agrupadores de celas mas com propriedades específicas, implementados de acordo com as necessidades apresentadas no processo de conversão.

delius.command: Este pacote armazena os objetos que implementam a interface ICommand e também o design pattern homônimo. Eles são responsáveis por manipular os itens dentro do documento. Inicialmente, o objeto que implementa ICommand é uma classe que é criada com a única função de modificar o objeto de modelo (Model) do MVC. Basicamente, ele recebe propriedades em seu construtor e implementa obrigatoriamente um método execute(). Na versão para esta aplicação, a interface ICommand exige a implementação do método execute() e undo(). Os objetos são criados e executados, porém não são descartados, e sim adicionados a uma pilha que permitirá que as operações realizadas possam ser desfeitas pelo usuário, se desejado. Abaixo, pode-se ver a interface ICommand com os métodos que devem ser implementados:

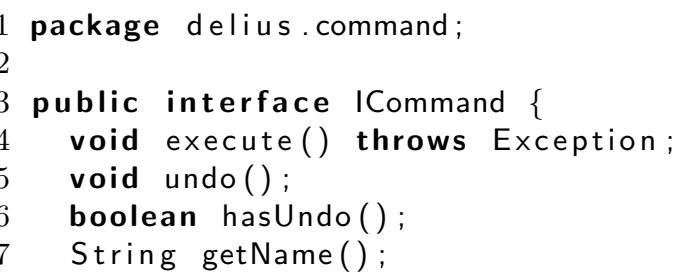

delius.parser: Aqui estão contidos os arquivos que verificam a integridade sintática e léxica da entrada em braille fornecida pelo usuário. Eles são gerados pelo arquivo MusBrl.g de definições da 
gramática a ser interpretada pelo componente externo ANTLR, o qual será detalhado na seção ??.

delius.view: Neste pacote ficam armazenadas as classes que dão respostas ao usuário como telas e sons.

delius.controller: Este pacote armazena as classes de controle, ou seja, aquelas que são capazes de, mediante as interações do usuário com a interface gráfica, disparar comandos (do pacote delius.command) e efetuar alterações no modelo. A classe Perkins, responsável por receber comandos do teclado e produzir as celas braille, também compõe este pacote.

delius.controller.options: Neste pacote estão os itens dos menus dinâmicos (os que são apresentados ao usuário quando ele se posiciona sobre um elemento da partitura e pressiona a tecla "I"). Trata-se de classes que implementam a interface IMenuOption. Os objetos instanciados são responsáveis por entender uma parte do modelo e, com base no estado do mesmo, disparar comandos (do pacote delius.command) que alterem seu estado. Estes objetos, quando instanciados, também disponibilizam para as telas de seleção o nome do comando (preparado para que seja traduzido para o idioma escolhido pelo usuário) e criam uma relação com um dos botões do menu; quando este botão é pressionado, dispara-se o método select() definido na interface, que inicia o processo de alteração do modelo. O código de definição dessa interface é apresentado a seguir:

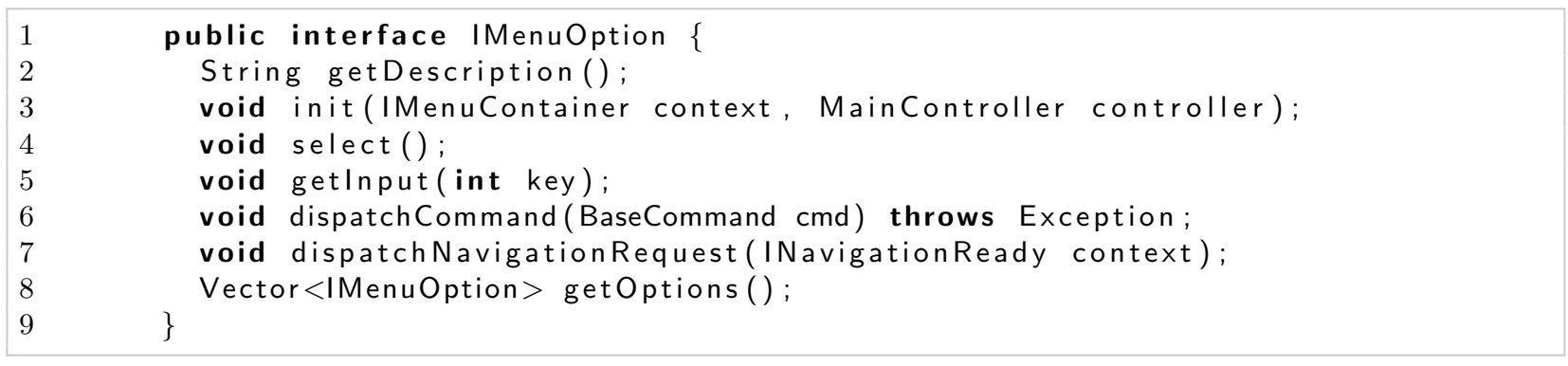

Outra vantagem de trabalhar com estas funções isoladas, que criam dinamicamente os menus contextuais, é que no futuro estas classes podem ser agregadas ao programa por reflection no momento de inicialização. Com isso, é possível tranformá-los em plug-ins, dando maior abertura para contribuições.

delius.input: Este pacote disponibiliza a interface IDeliusInput, que deve ser implementada para se criar adaptadores para entrada de dados no Delius. As classes que a implementam devem ser responsáveis por pegar qualquer formato de arquivo (MIDI, MusicXML, BMML, etc) e fazer modificações no documento musical contido no modelo de representação. O seguinte código define esta interface:

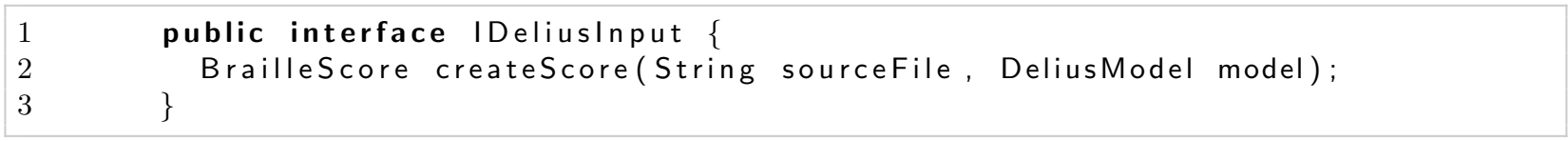

delius.output: Este pacote disponibiliza a interface IDeliusOutput, que por sua vez é implementada para criar classes capazes de exportar o conteúdo das partituras para outros formatos. Abaixo, a definição da interface IDeliusOutput: 


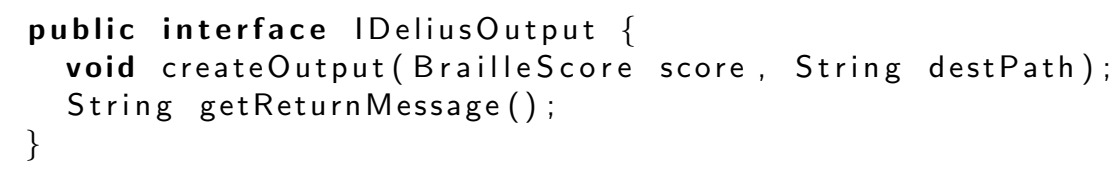

delius.formatter: Este pacote reúne as classes responsáveis pela diagramação do conteúdo musical, de acordo com as regras apresentadas na seção sec:OrganizacaoLeiaute. Para cada novo modelo de leiaute, é necessário criar uma extensão da classe abstrata AbstractFormatter. Essa classe é utilizada pelo componente gráfico que produz as páginas em braille na tela e também pelo componente responsável por produzir a saída para a impressora braille.

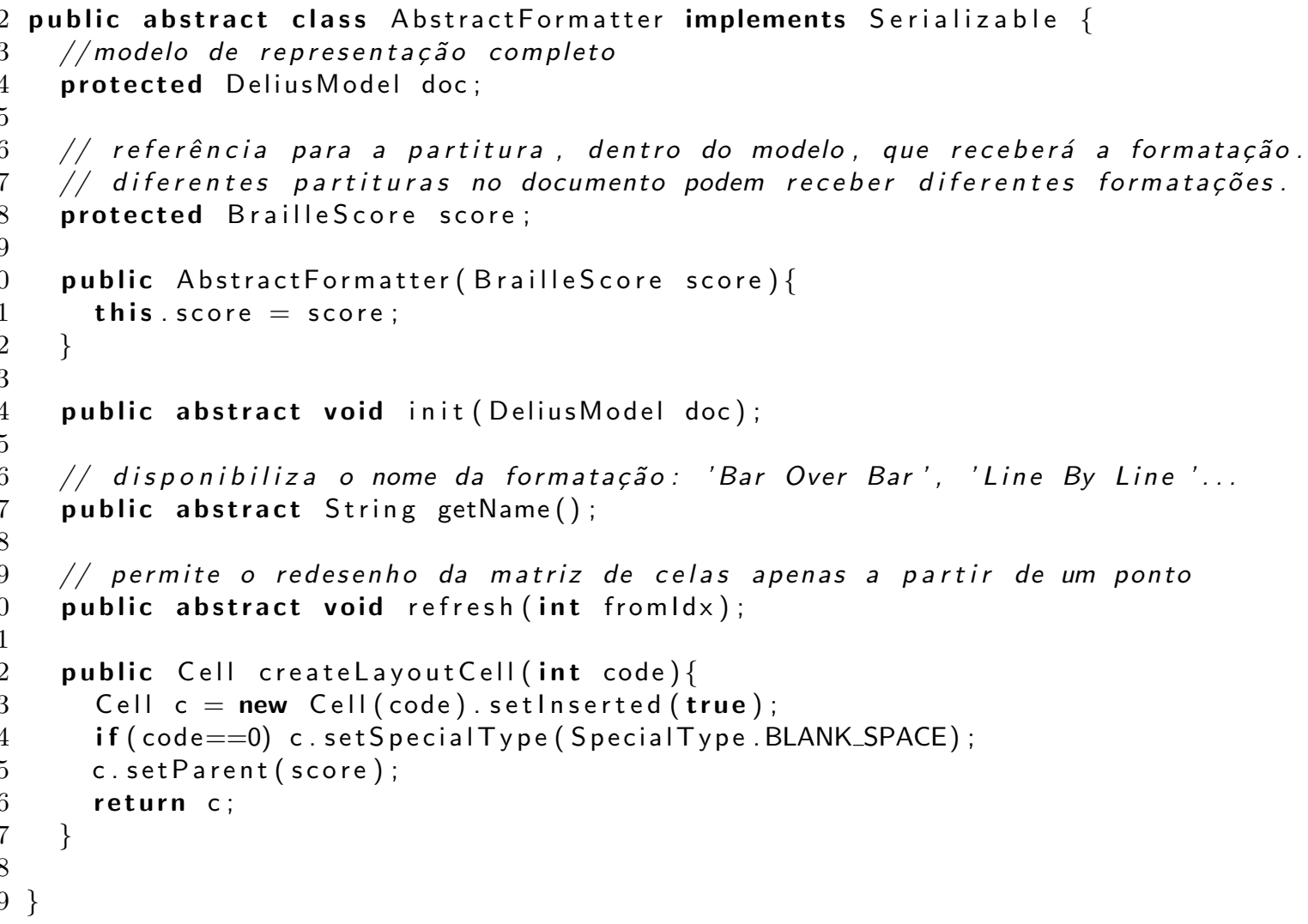

delius.intl: Este pacote contém classes para a tradução das chaves mnemônicas que são lançadas para a saída do usuário no idioma selecionado. Como este aplicativo é orientado a pessoas cegas, a transformação em texto deverá ser cuidadosa. O resultado esperado é que as saídas sejam frases e expressões idiomaticamente corretas e coesas, e não meras traduções dos comandos do usuário.

A classe mais importante neste pacote é a TranslationManager. Esta classe implementa o padrão Singleton, no qual garante-se que, em todo o escopo da aplicação, apenas uma instância desta classe será criada. No início do programa, esta classe lê um dicionário de chaves e suas respectivas traduções, o qual utilizará para produzir os textos dos componentes gráficos no idioma do usuário. 


\subsection{Demais componentes utilizados}

Para determinadas funções, o Delius utiliza alguns componentes externos que implementam funcionalidades úteis ao programa e que também são distribuídos sob licenças públicas compatíveis. A figura 3.6 mostra a utilização destes componentes externos pelo Delius, que serão detalhados abaixo.

\section{Proxymusic}

Este componente ${ }^{7}$, cuja licença é GNU LGPL, permite a transformação dos elementos XML contidos em um arquivo MusicXML para objetos Java e vice-versa, o que facilita o processo de transformação dos elementos simbólicos musicais em dados serializáveis. O Proxymusic é parte importante do processo de transformação para o formato de saída MusicXML e também colaborará, futuramente, para que o processo inverso seja feito.

\section{abc4j}

Este componente (de licença GNU LGPL) foi inicialmente desenvolvido para trabalhar com a notação $a b c^{8}$, uma forma textual de escrita musical desenvolvida para ser compacta e ao mesmo tempo humanamente legível. Seu objetivo principal era poder representar música tradicional da europa ocidental (principalmente inglesa, escocesa e irlandesa) que pudesse ser escrita em pauta simples. Porém, este componente agrega uma série de recursos extra, como a possibilidade de execução de excertos musicais em MIDI, e é utilizado para a geração de áudio pelo programa. Uma vez que o material de um compasso ou sistema esteja semântica e sintaticamente correto, pode ser processado para notação abc e imediatamente executado como resposta sonora.

Além destes componentes mencionados, há também o ANTLR, detalhado na seção 4.4.

\subsection{Formatos de importação e exportação}

É responsabilidade do modelo de representação atuar como linguagem intermediária para a geração de saída para diversos outros formatos de representação musical simbólica. Entende-se que a produção musical no Delius não deve limitar-se ao uso dentro do próprio programa. Pela variedade de diferentes necessidades e interesses do público-alvo do programa, é fundamental promover ao máximo a integração deste com diversos outros softwares.

Muito embora alguns formatos de saída já estejam implementados (ainda que parcialmente, em alguns casos), é importante prover uma maneira de que essas integrações sejam expansíveis - não só no que se refere à saída do programa, pois também é possível permitir que o programa receba arquivos em diferentes formatos, embora neste momento do trabalho essa não seja a principal preocupação.

Por essas necessidades, foram disponibilizadas duas interfaces bastante simples, uma para entrada e uma para saída. A primeira, IDeliusInput, oferece o método createScore; a classe que a implementa deve utilizar-se desse método para converter um arquivo qualquer em um objeto do tipo BrailleScore, com total autonomia sobre a maneira com que faz isso. A segunda classe, IDeliusOutput, efetua o processo oposto, recebendo o conteúdo de um objeto BrailleScore e um caminho no disco, onde deverá produzir uma saída, no formato que for pertinente ao componente que implementa a interface. No estado atual, as entradas e saídas já disponibilizadas pelo programa

\footnotetext{
${ }^{7}$ http://proxymusic.kenai.com, 05/2011

${ }^{8}$ http://www.abcnotation.com, 05/2011
} 
e o estado de evolução são mencionadas na tabela 3.2.

\begin{tabular}{|c|c|c|}
\hline $\mathrm{E} / \mathrm{S}$ & Formato & Estado \\
\hline $\begin{array}{l}\text { entrada } \\
\text { entrada }\end{array}$ & $\begin{array}{l}\text { delius } \\
\text { BMML }\end{array}$ & $\begin{array}{l}\text { completo } \\
\text { parcial }\end{array}$ \\
\hline $\begin{array}{l}\text { saída } \\
\text { saída } \\
\text { saída } \\
\text { saída } \\
\text { saída }\end{array}$ & $\begin{array}{l}\text {.delius } \\
\text { MusicXML } \\
\text { texto } \\
\text { abc } \\
\text { MIDI }\end{array}$ & $\begin{array}{l}\text { completo } \\
\text { parcial } \\
\text { completo } \\
\text { parcial } \\
\text { parcial }\end{array}$ \\
\hline
\end{tabular}

Tabela 3.2: Entradas e saídas e estado de implementação

O arquivo .delius é o arquivo proprietário do programa, uma serialização binária do modelo, englobando o documento e a estrutura abaixo dele. O arquivo BMML foi introduzido tardiamente como formato para importação, na intenção de estudar sua compatibilidade com o modelo de representação do Delius. Constatou-se que o processo de leitura deste arquivo é bastante simples, pois nele cada elemento musical carrega consigo a indicação das celas braille utilizadas. O processo, até o momento, consiste em ler todas as celas, localizar em qual instrumento e compasso elas devem ser inseridas e, convertendo-as para objetos do tipo Cell elas são inseridas no buffer dos compassos apropriados.

Quanto às saídas, a saída para MusicXML é considerada a grande prioridade, por permitir a troca de informação com uma quantidade maior de softwares e por permitir uma representação tão abrangente quanto possível pelo processo de tradução. Trata-se por parcial pela impossibilidade de contemplar, nesta etapa atual, todas as regras da musicografia braille, embora tenha alcançado satisfatoriamente o escopo inicialmente determinado, como será visto nas conclusões finais.

O formato de texto diz respeito à saída para impressora braille. É um arquivo texto comum, produzido por mera transliteração de caracteres braille para o formato ASCII.

\subsection{Conclusão do capítulo}

Este capítulo expôs, inicialmente, as necessidades e os princípios que norteiam o desenvolvimento do Delius. Discutiu-se as questões de acessibilidade e usabilidade, detalhando as práticas que foram adotadas para que a apresentação, desenvolvida utilizando o Java Swing, trouxesse bons resultados quanto à adaptação da interface gráfica para baixa visão, bem como sua tradução para forma audível, por aplicativos leitores de tela. Também foram apresentados os padrões arquiteturais e os componentes externos utilizados pelo programa. O próximo capítulo detalhará o modelo de representação (Model) que compõe o padrão MVC utilizado pela arquitetura do programa, e falará também dos processos de conversão entre as linguagens musicais. 


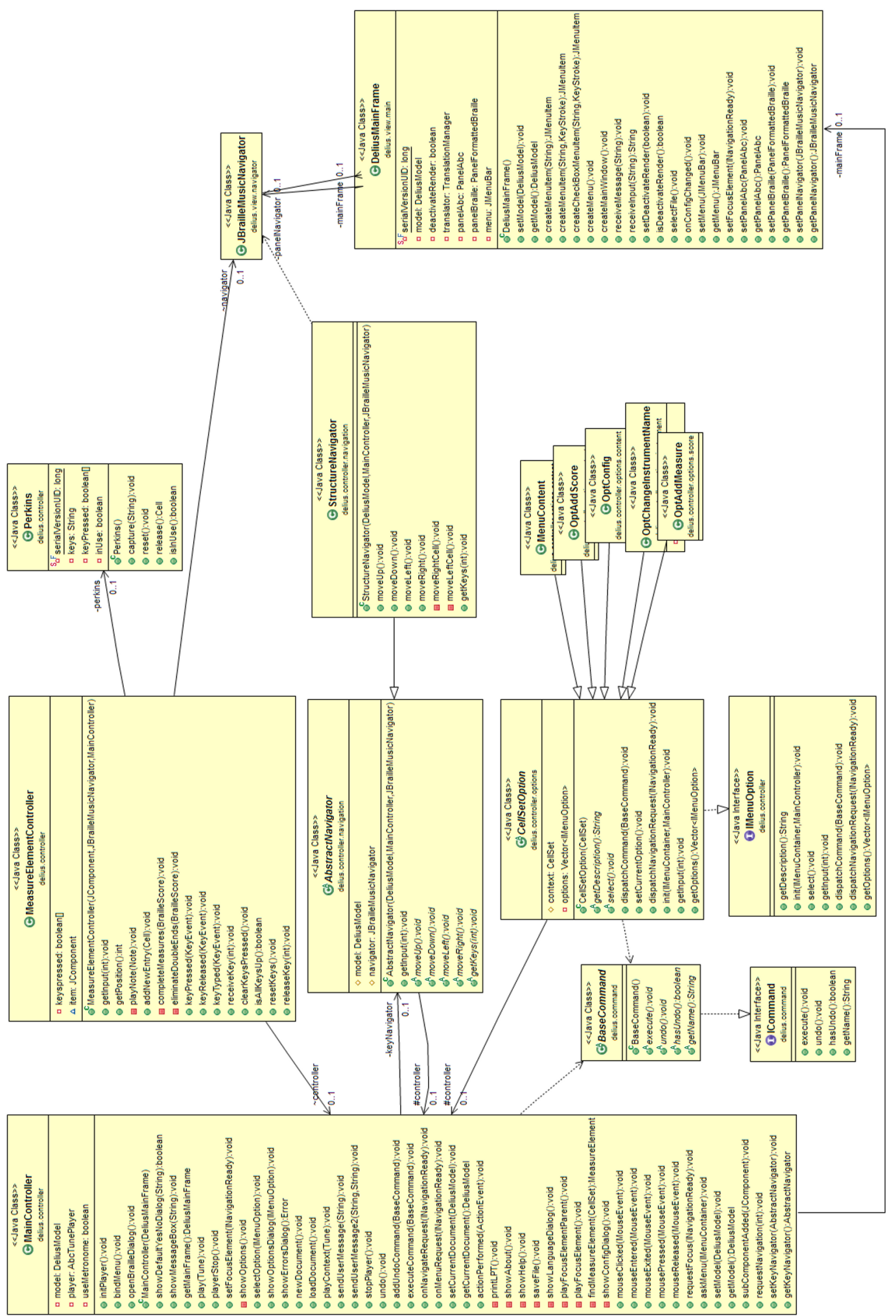

Figura 3.5: Diagrama de classes mostrando como as classes de controle relacionam-se com as classes de visão e de modelo. 

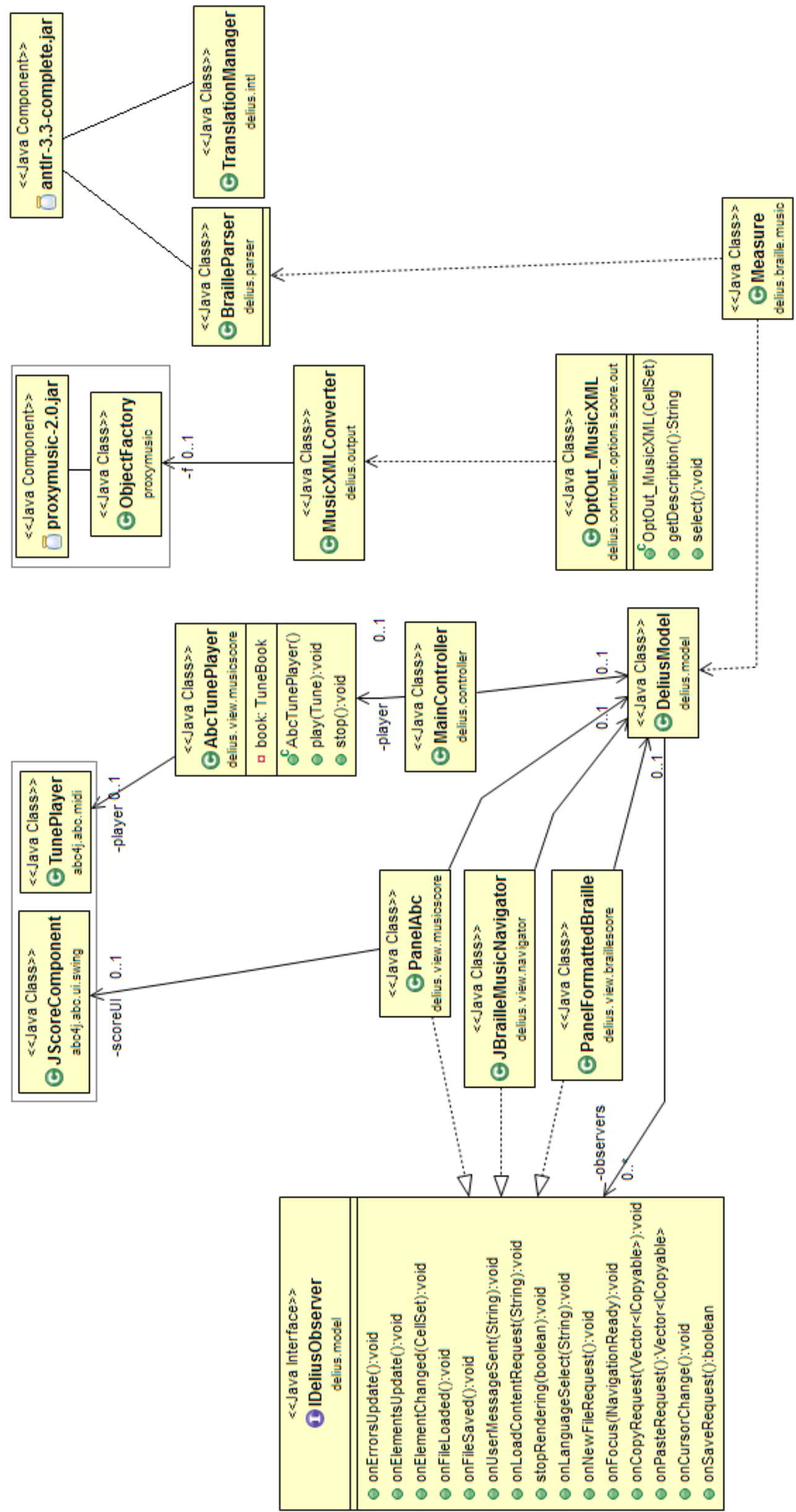

Figura 3.6: Diagrama de classes mostrando a utilização dos componentes externos pelo Delius. 


\section{Capítulo 4}

\section{Modelos computacionais de representação musical e conversão}

Este capítulo discutirá as formas de representação da informação musical em modelos computacionais estruturados para manipulação por programação orientada a objetos, levando em consideração as diferenças e semelhanças entre uma partitura musical em braille e no modelo gráfico tradicional. Também tratará do processo de conversão, tendo a musicografia braille como origem e a notação musical tradicional como destino, buscando uma estrutura de objetos que possa ser utilizada na camada de abstração do programa, que seja adequada para intermediar tal conversão.

Vários linguagens foram definidas, nas últimas décadas, na intenção de representar música em um grau de abstração suficiente para permitir a troca da informação representada entre diferentes softwares. Mais do que apenas garantir a cobertura satisfatória de elementos musicais e suas propriedades, certas linguagens diferem-se de outras por motivos específicos como adequação ou implementação de algum determinado padrão ou pela possível necessidade do formato de produzirem documentos humanamente legíveis, entre outros motivos.

Uma das abordagens utilizadas para a definição dessas linguagens de representação musical é a segmentação da informação de acordo com determinados aspectos, organizando-a em diferentes níveis de abstração dessa informação musical. O formato SMDL (Standard Music Description Language) (Newcomb, 1991), por exemplo, utiliza-se de quatro níveis de abstração, tratados por domínios: domínio lógico, gestural, visual e analítico. Downie (2003), por sua vez, busca uma divisão em 7 domínios diferentes: altura ( $p i t c h$ ), temporal, harmônico, timbral, editorial, te xtual e bibliográfico. Haus e Longari (2005) baseia-se no SMDL e cria um modelo dividido em 6 camadas (informações gerais, estrutural, lógica, notacional, performance e áudio), incrementando seu modelo com uma estrutura definida como spine, que atua como o agente que relaciona todas essas camadas, mantendo-as unidas por meio de eventos de sincronismo nos domínios temporal e espacial. A escolha e até mesmo a proposição de novos modelos relaciona-se com os fins específicos de cada programa: o domínio visual do SMDL, por exemplo, tem uma importância particular para programas de edição ou reconhecimento gráfico de partituras, sendo no entanto pouco relevante para rotinas de sequenciamento ou MIR. Para os propósitos do Delius o SMDL, ainda que mais simples do que outros modelos aqui apresentados, é um modelo cujo entendimento de "domínios musicais" é bastante pertinente para se analisar o espectro de informações inerente à musicografia braille, muito embora o formato SMDL em si não esteja preparado para contemplar o código braille. Mais detalhadamente, os domínios definidos pelo SMDL são:

- Domínio lógico - contém os elementos musicais

- Domínio gestural - contém informações de caráter performático

- Domínio visual - define propriedades gráficas da obra 
- Domínio analítico - contém informações e comentários de edição, informações de caráter analítico e outras.

O domínio lógico compreende a parte mais densa das regras de musicografia braille. Basicamente ele pode ser descrito como "as intenções do compositor no que diz respeito às alturas das notas, ritmos, harmonias, dinâmicas, articulações, etc.". Comparando as grafias em braille e tinta, a informação musical pertencente a este domínio pode ser separada em três subconjuntos:

- símbolos existentes simultaneamente nas grafias em braille e em tinta (notas, pausas, crescendo, etc)

- símbolos específicos da musicografia braille (indicação de mão, indicação de valores de duração, alguns tipos de repetição, em-acorde)

- símbolos específicos da musicografia em tinta tradicional que não possuem função na musicografia braille, mas garantem fidelidade às transcrições (sinais de clave, notas agrupadas ${ }^{1}$ ).

O domínio gestural relaciona-se à informação capaz de sintetizar uma performance específica, a partir das intenções do compositor, definidas no domínio lógico, processada pelos intérpretes ou regentes. O domínio analítico é constituído de análises e comentários que de alguma forma se compõem de opiniões ou interpretações de pessoas. Na musicografia braille é possível inserir blocos de anotações de texto em praticamente qualquer lugar, além de espaços previstos pelo manual para bulas introdutórias e anotações de rodapé. As informações contidas nestes dois domínios, via de regra, podem portanto ser representadas na musicografia braille.

O domínio visual, pela definição do SMDL, trata de como o domínio lógico deve ser apresentado visualmente, dada uma edição em particular, atendendo aos requisitos de diagramação de página, medidas, fontes e símbolos utilizados. Este domínio é particularmente interessante com relação à musicografia braille, pois embora as especificações com relação a este domínio relacionarem-se com resultados visuais propriamente ditos, as regras e exigências para a diagramação do documento em braille $^{2}$ têm uma importância equiparável a dos elementos musicais presentes no domínio lógico, sendo responsáveis pela organização e indexação da informação musical para a leitura tátil. Para estes fins específicos, portanto, entender o domínio visual no sentido estrito não é conveniente, porém preserva-se adequadamente se redefinido como dominio estrutural ou de apresentação.

Esta divisão do conteúdo musical em domínios permeará a discussão dos processos de conversão, pois a divisão por domínios do conteúdo musical é bastante útil ao se fazer comparações entre a musicografia braille e tradicional. A proposição do modelo de representação utilizado pelo Delius deverá herdar estes domínios do SMDL, porém adaptando-os às necessidades do código da musicografia braille.

Um primeiro detalhe a ser observado neste instante é que os símbolos utilizados para definir estruturalmente a partitura em braille, neste domínio visual, são os mesmos utilizados para representar todo o tipo de informação de todos os outros domínios, extraídos do mesmo alfabeto de 64 símbolos apenas. Juntamente com as regras estruturais de posicionamento, cada um dos modelos de leiaute apresentados na seção 2.9 preza por um conjunto de formalidades e exigências que transcendem este domínio. A exemplo disso, pode-se citar a regra de exigência de sinal de oitava em cada compasso que é característica do formato compasso sobre compasso apenas (e por motivos próprios da maneira com que se espera que o músico faça a leitura do documento), claramente, esta regra tem implicações muito maiores no domínio lógico do que no estrutural/visual.

\footnotetext{
${ }^{1} \mathrm{o}$ agrupamento de notas, em braille, tem uma intenção um pouco diferente da grafia em tinta, procurando economizar na quantidade de punções ao se escrever as notas, tornando o processo menos cansativo.

${ }^{2}$ veja seção 2.9
} 
Para este mesmo formato de compasso sobre compasso, há uma exigência da repetição dos sinais de mãos no início de cada novo bloco. Claramente, esta exigência está preocupada com procedimentos de leitura, uma vez que o transcritor, utilizando uma máquina Perkins e papel, deve dobrar sua atenção a fim de não equivocar-se quanto ao posicionamento das celas na folha. Com o apoio de recursos tecnológicos, este contratempo poderia ser não só resolvido, dado que o programa colocaria o símbolo adequadamente no começo das linhas, como também traria a possibilidade do usuário modificar, por exemplo, a quantidade de compassos contidos em cada bloco, podendo assim testar possibilidades de diagramação na medida que preocupa-se menos com posições fixas obrigatórias de elementos no documento. Além disso, a experiência de produção de conteúdo, seja musical ou literário, em uma máquina Perkins ou em software é diferente; embora a grafia pelo método puramente mecânico seja silenciosa (ou melhor, não receba "assistência" da máquina), o acesso à informação produzida na folha é tão simples como tatear o papel à frente. Já o processo eletrônico traz a possibilidade de assistência à produção de conteúdo válido e consistente, mas informar a posição de coordenadas de um símbolo no papel é, no mínimo, uma informação a mais a ser enviada ao usuário em formato de som. Esta informação pode vir em conjunto com as outras ou, separadamente mediante configurações mas, de qualquer maneira, preocupar-se com a quantidade de toques realizados ou a serem realizados em uma linha - ou a quantidade de linhas utilizadas em uma folha - é mais difícil e cansativo nesta produção por meio eletrônico. Complementarmente, é comum ver aplicativos para produção de texto literário tomarem as rédeas da formatação gráfica do material neles produzidos com o devido sucesso - e este poderia ser um caminho adequado também neste caso.

\subsection{Principais formatos de representação musical}

\section{O formato MusicXML}

Durante muito tempo programas de notação musical utilizaram formatos binários específicos, de forma que o compartilhamento dessa informação com outros programas não era favorecido. Era comum que tais programas possuíssem métodos de importação e exportação em formato MIDI, proporcionando portanto alguma comunicabilidade. Os arquivos MIDI, porém, não foram estruturados para lidar com uma série de elementos da notação musical da forma como são simbolizados em uma partitura musical gráfica (Good, 2001).

Suponha, por exemplo, um compasso com quatro notas com um sinal de crescendo, criado em um programa de notação musical e exportado para o formato MIDI; possivelmente veríamos no arquivo final que as notas do compasso teriam o atributo velocity ${ }^{3}$ aumentado gradativamente, e um reprodutor MIDI as tocaria dando a impressão do crescendo, mas a notação propriamente dita desse elemento estaria perdida, uma vez que a reinterpretação simbólica/gráfica a partir do atributo velocity das notas não é óbvia. Outro exemplo clássico de perda de informação musical em arquivo MIDI é o da perda de armadura de clave e fórmula de compasso, além dos textos em linhas vocais.

De acordo com Good (Good, 2001), formatos próprios para compartilhamento de informação musical foram propostos, mas sem sucesso na adoção como um padrão. O formato NIFF (Cunningham, 2004; Good, 2001) foi uma tentativa de adoção de um padrão para tais fins; inicialmente foi utilizado com eficácia em aplicações de reconhecimento ótico de partituras e realmente o formato contemplava mais informação simbólica musical do que o MIDI, mas sua abordagem predominantemente gráfica o tornava inferior ao MIDI para uso em aplicações de execução ou análise musical.

\footnotetext{
${ }^{3} \mathrm{O}$ atributo velocity é onde parametriza-se no formato MIDI a dinâmica de uma nota musical. Define-se por um valor entre 0 e 127 , do mais fraco para o mais forte.
} 
MusicXML é uma linguagem de marcação para representação de informação simbólica musical baseada em XML ${ }^{4}$. Essa linguagem é totalmente representada em texto, de forma a ser adequadamente estruturada para leitura por máquina e humana. O formato MusicXML foi idealizado pela Recordare $\mathrm{LCC}^{5}$ tendo como objetivo justamente suprir essa carência de um formato consistente e robusto que pudesse ser usado na troca de informação musical entre aplicativos, que fosse suficientemente versátil para poder ser utilizado em diversas aplicações, seja para notação musical ou para fins musicológicos.

A figura 4.2 mostra como o arquivo MusicXML representa uma partitura musical; a figura 4.1 mostra o resultado gráfico oriundo do mesmo arquivo MusicXML. Mesmo sendo um exemplo bastante simples, com apenas uma nota, o arquivo XML utiliza quase quarenta linhas de código para descrevê-lo. O aninhamento da informação em blocos garante uma rigorosidade formal que é fundamental para a leitura e interpretação por computadores. Mesmo sendo pouco prático, o conteúdo do arquivo ainda pode ser lido e escrito diretamente por pessoas.

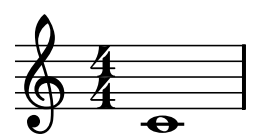

Figura 4.1: Versão em tinta do arquivo MusicXML - helloworld.xml

O formato MusicXML será utilizado como destino do processo de conversão de braille para tinta, não apenas por conta de sua notória estruturação e legibilidade (ilustrada na figura 4.2) e contemplação satisfatória dos símbolos musicais encontrados na música ocidental do século XX, mas sobretudo pela sua ampla aceitação por parte dos principais softwares musicais produzidos desde o advento deste formato.

O site da Recordare $\mathrm{LCC}^{6}$ mantém uma lista atualizada dos aplicativos que utilizam MusicXML para fins diversos (ver tabela 4.1), além de muitos outros que implementam o formato apenas parcialmente para leitura ou escrita e alguns ainda em fase de protótipo ou de testes:

\begin{tabular}{|lll|}
\hline Allegro & capella & Cubase \\
Drindlefish & Eletric Pipes & Encore \\
Finale & Finale NotePad & Forte \\
Free Clef & Guitar Pro & Harmony Assistant \\
iComposer & JFugue & KOffice \\
Lime & MagicScore & MusEdit \\
MuseScore & MusicXML Library & Noteflight \\
NOTION & Nuendo & Obtiv Octava \\
OpenMusic & Open Score Format & Pizzicato \\
PriMus & PrintMusic & Progression \\
ProxyMusic & QuickScore Elite Level II & SCORE \\
Score Perfect Professional & Scorio & Sibelius \\
SmartScore & SongWriter & Speech Analyser \\
Symphony Pro & TaBazar II & TablEdit \\
\hline
\end{tabular}

Tabela 4.1: Tabela de softwares compatíveis com MusicXML

Segundo Arora (2010), o fato do formato MusicXML ser baseado na linguagem XML permite

\footnotetext{
${ }^{4}$ http://www.w3.org/XML/

${ }^{5}$ http://www.recordare.com

${ }^{6}$ http://www.recordare.com, acesso em 05/2010
} 


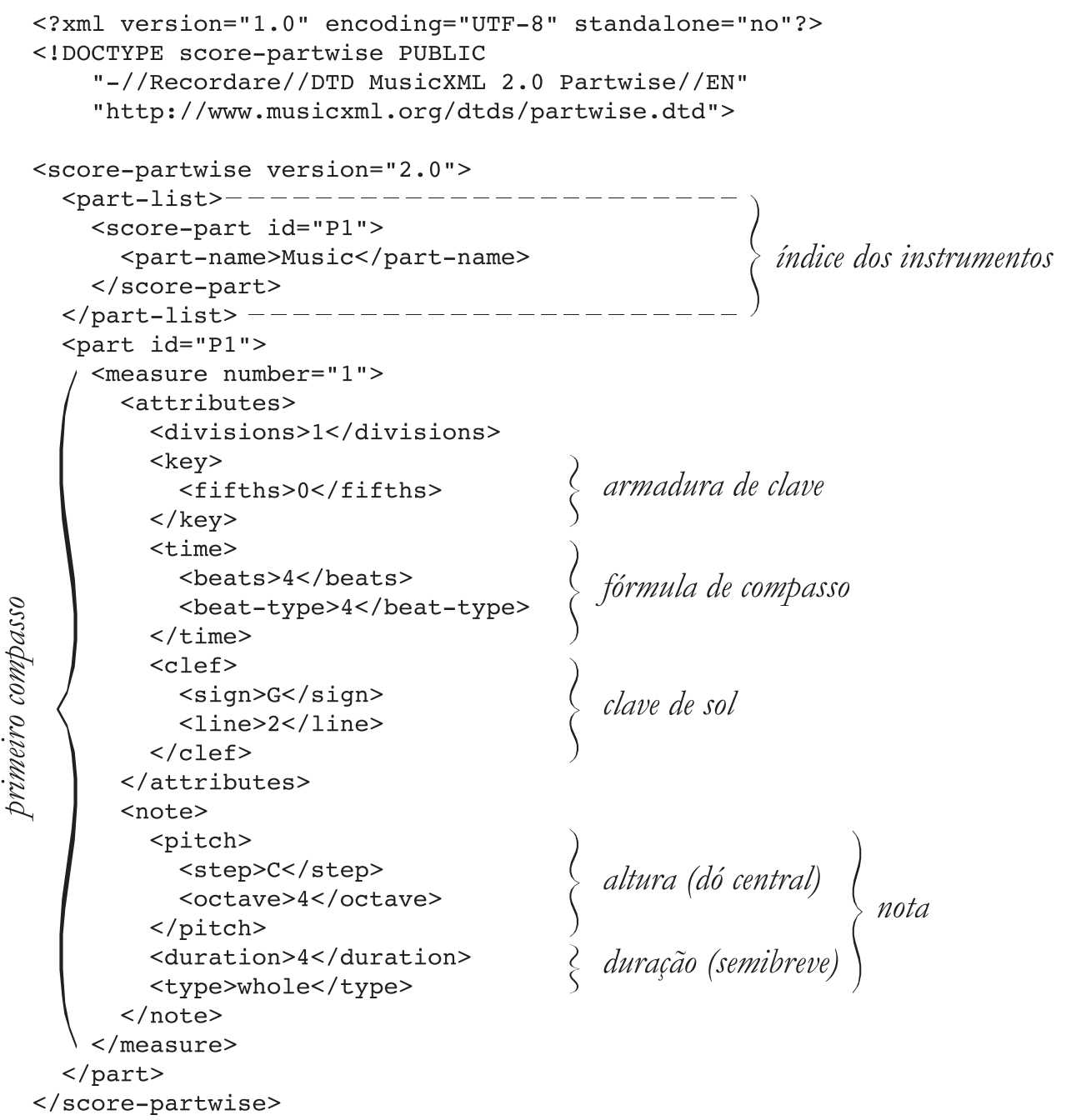

Figura 4.2: conteúdo do arquivo MusicXML - helloworld.xml

que tecnologias como XQuery ${ }^{7}$ e XSLT $^{8}$ possam ser associadas ao mesmo, estendendo assim seu uso a uma série de possibilidades como por exemplo aplicações de MIR (Arora, 2010; Cuthbert, 2010).

\section{O formato BMML}

O formato BMML também é baseado na linguagem de marcação XML e orienta-se às particularidades da musicografia braille em diversos aspectos, tanto simbólicos, sendo capaz de representar símbolos específicos desta linguagem (não presentes na musicografia tradicional em tinta), como também da diagramação e condução da leitura, de caráter também específicos.

Diferentemente do formato MusicXML, sua estrutura não contempla a divisão dos elementos musicais por compassos. Há um elemento que representa a barra de compasso, e através dele é que se faz possível que qualquer interpretador consiga fazer o agrupamento de elementos pelo contexto de compassos musicais. Além disso, o elemento estrutural mais importante, cuja responsabilidade é agregar os elementos musicais, é o elemento part, que representa um pentagrama de

\footnotetext{
${ }^{7}$ XQuery é uma linguagem para inferência de consultas em XML; http://www.w3.org/TR/xquery, visitado em $05 / 2010$

${ }^{8}$ XSLT é uma linguagem para transformação de documentos XML em outros documentos XML; http://www.w3.org/TR/xslt, visitado em 05/2010
} 
um determinado instrumento. Uma partitura para piano com dois pentagramas, por exemplo, seria representada em um documento BMML por elementos do tipo part com dois identificadores (atributo id) diferentes. Esta informação é importante para que se discorra sobre a maior discrepância deste formato com relação ao MusicXML: cada elemento do tipo part aparecem em um documento mais de uma vez, de forma que os elementos musicais ficam divididos entre várias instâncias destes elementos. Com isso, o formato privilegia a distribuição da informação dentro das estruturas de leiaute definidas em 2.9. Observa-se, portanto, que a distribuição da informação musical no formato BMML é privilegiada no domínio estrutural.

Além da informação musical definida estruturalmente, através de elementos e atributos XML, este formato também representa as celas braille propriamente ditas, através dos caracteres Unicode relativos aos sinais braille, conforme ilustra a figura 4.3.

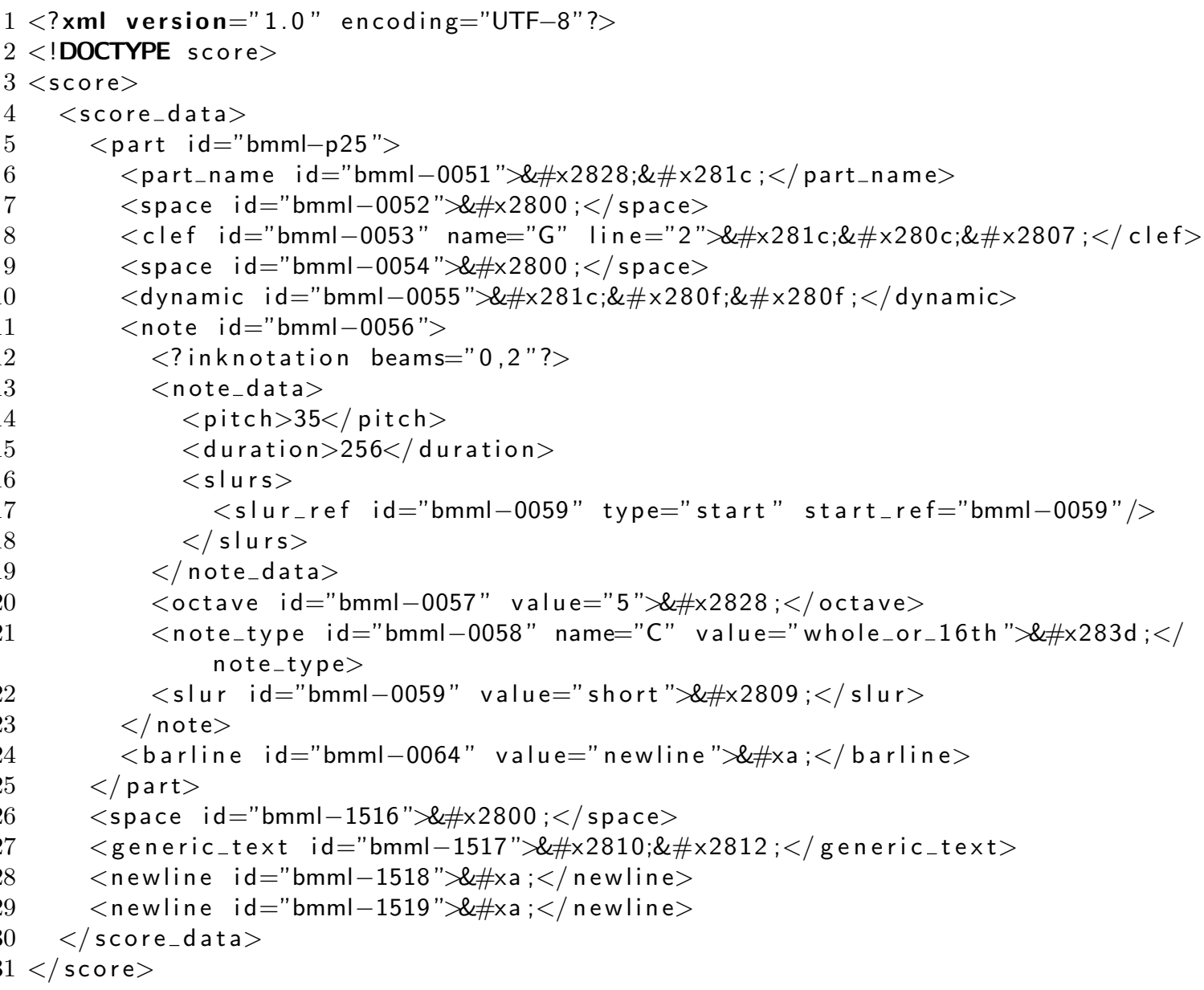

Figura 4.3: Exemplo de representação musical pelo formato BMML

\subsection{Outros formatos de representação musical}

Esta seção investigará alguns outros formatos utilizados para representação musical, independentemente do caráter de construção e domínios representativos, porém por serem formatos mais amplamente difundidos, motivo pelo qual mostram-se fortes candidatos a integrar a lista de formatos para exportação do Delius.

O formato NIFF é um formato de representação com ênfase no aspecto visual da partitura musical, promovendo para tanto parâmetros que garantem precisão neste tipo de representação e 
sendo, portanto, utilizado primordialmente por programas de reconhecimento ótico via scanner e de impressão.

O MIDI (Musical Instrument Digital Interface) é um protocolo de comunicação amplamente difundido na indústria musical. Seu formato de arquivo é bastante utilizado como objeto de importação e exportação entre softwares de notação e sequenciamento musical, embora com muitas perdas, uma vez que seu foco é o disparo de eventos musicais ou, de forma simplificada, a produção de som efetivamente.

O formato PLAY, utilizado pelo software Braille Music Editor, dirige-se à representação musical baseado na entrada da informação musical em braille. Este formato, porém, é um formato fechado, não sendo facilmente reutilizável ou extensível.

Fica evidente, portanto, que por mais que esforços sejam aplicados na busca de uma abstração ideal, é difícil crer na possibilidade de concepção de um modelo de representação suficientemente abrangente, capaz de representar a música "em toda sua essência", servindo para todo e qualquer propósito; vale a pena lembrar ainda que todos os modelos aqui apresentados preocupam-se primordialmente com a música tradicional ocidental, e que esta está longe de ser a única, e não necessariamente tais modelos sejam capazes de representar gêneros orientais, antigos e muitos outros.

\subsection{Definição do modelo de representação em objetos}

O modelo de representação a ser utilizado pode ser entendido como um conjunto de classes, escritos na linguagem Java, relacionados entre si através das formas possíveis de acordo com o paradigma de programação orientada a objetos. Talvez um dos pontos mais críticos de todo o desenvolvimento deste aplicativo (e de muitos outros) é a distribuição adequada destes modelos em classes e a relação que se faz entre elas; isso é determinante para uma série de questões como a expansibilidade do modelo, a complexidade computacional de acesso à informação e a garantia de integridade do modelo em um conjunto de estados válidos.

O modelo atualmente utilizado no Delius foi desenhado mediante a observação dos seguintes fatores:

1. suas formas de entrada, sendo a principal delas a digitação do usuário

2. as possíveis maneiras de navegação do usuário pelos elementos musicais contidos no modelo

3. a necessidade de se produzir saída e representação gráfica imediata, a partir da entrada do usuário

4. a persistência do objeto para reuso e compartilhamento

5. os processos de conversão

Lassfolk (2004), ao tratar dos problemas da definição de modelos de representação musical com orientação a objetos, divide as estruturas de agregação de classes em dois níveis (alto e baixo), onde o primeiro nível estrutural relaciona-se mais diretamente à organização estrutural dos elementos musicais, enquanto que o segundo nível refere-se aos elementos musicais propriamente ditos. Claramente, os fatores apresentados acima relacionam-se com estes dois níveis de maneiras distintas. A apresentação do modelo criado para o Delius será portanto dividida em duas partes, de acordo com estes níveis, discutindo-os individualmente e comparando-os com outros modelos propostos. 


\section{Estrutura de alto nível}

Com base nos primeiros dois itens enumerados acima, optou-se por buscar uma maneira de interpretar a informação musical como conjuntos simbólicos e seus subconjuntos, aninhados por uma estrutura de árvore, tendo raiz no grau de informação mais genérica e abrangente (o documento musical como um todo), até a informação mais específica, baseada nos símbolos musicais e suas propriedades (notas e elementos de compasso). Sabe-se que a adoção deste tipo de estrutura é trivial quando se utiliza programação orientada a objetos, mas a definição dessa hierarquia requer algum cuidado. No caso específico da representação musical é bastante comum comparar modelos e perceber divergências na concepção do que é essa parte estrutural. Essa divisão da informação musical em domínios revela um caráter prismático que justifica uma série de situações de ambiguidade quanto às hierarquias entre as informações; dependendo do ponto de vista e dos objetivos da leitura, certos elementos podem impôr-se hierarquicamente a outros. Lassfolk (2004) discorre que para a definição deste alto nível é necessário levar em consideração quais são, para os fins específicos, os elementos necessários e os desnecessários, a fim de organizar corretamente e da forma mais simplificada possível a relação de agregação entre as estruturas. Segundo seu trabalho, a relação de agregação entre página, sistema e pentagrama pode não ser única; na notação musical é permissível que se tenha pentagramas que não pertençam a sistema nenhum, de forma que o elemento pentagrama poderia relacionar-se diretamente com o elemento página. Da mesma forma, buscando uma organização entre objetos, o elemento compasso pode agregar-se diretamente ao elemento pentagrama ou ao elemento instrumento; embora seja possível garantir o acesso a todos os compassos, a partir do ponto estrutural mais alto, a facilidade em se localizar e em se percorrer estes elementos dentro da estrutura pode variar.

Lassfolk, ainda no mesmo trabalho, propõe uma estrutura de alto nível onde o nível mais alto é a partitura em si, que por sua vez é dividida em páginas, sendo cada página dividida por sistemas e cada sistema composto por pentagramas, como pode ser visto na figura 4.4. No nível de pentagrama agrega-se outros símbolos. O compasso é, neste caso, uma consequência da presença de símbolos dentro do pentagrama que representem as barras de compasso. Não é, portanto, algo de caráter estrutural, embora possa ser perfeitamente identificado por uma varredura no modelo.

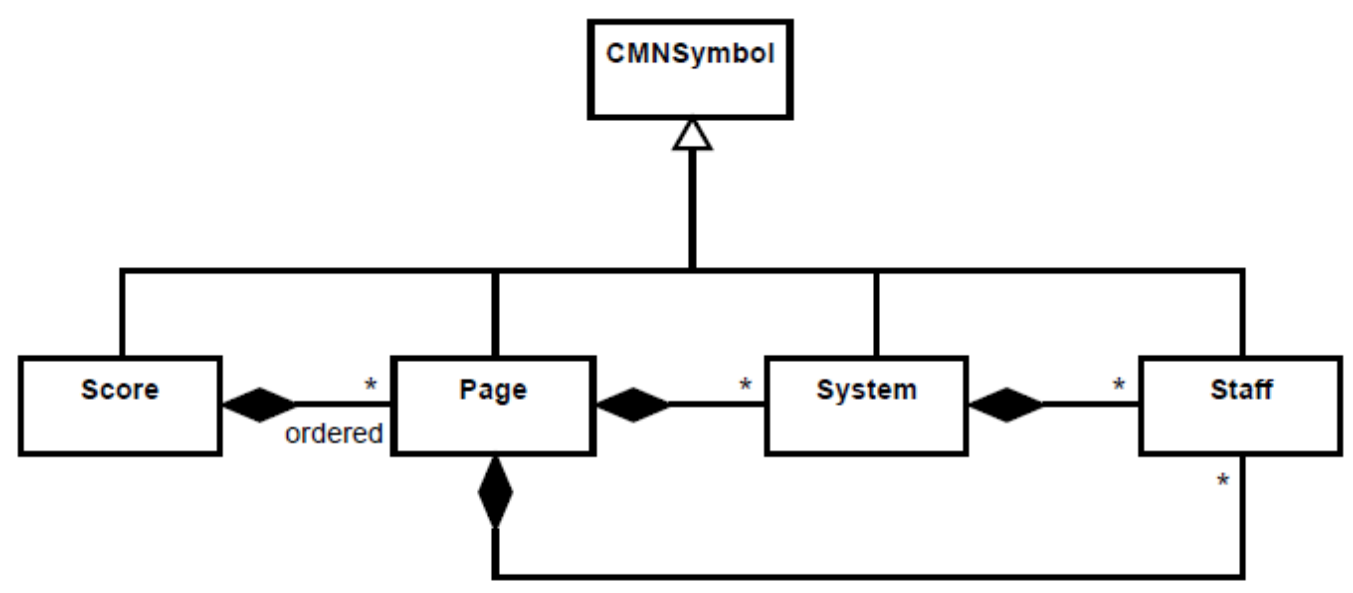

Figura 4.4: Modelo de representação de Lassfolk

O formato MusicXML lida com essa questão disponibilizando duas versões diferentes, definidas por partwise e timewise. No primeiro caso, coloca-se o elemento do pentagrama em um grau hierárquico acima do elemento de compasso, favorecendo portanto a leitura e escrita do documento como vários blocos (ou segmentos) horizontais. No segundo caso, o elemento de compasso é o mais importante, tendo o elemento de pentagama como seu subordinado, privilegiando seu entendimento 
como blocos verticais. A figura 4.5 ilustra a diferença entre estas variações.
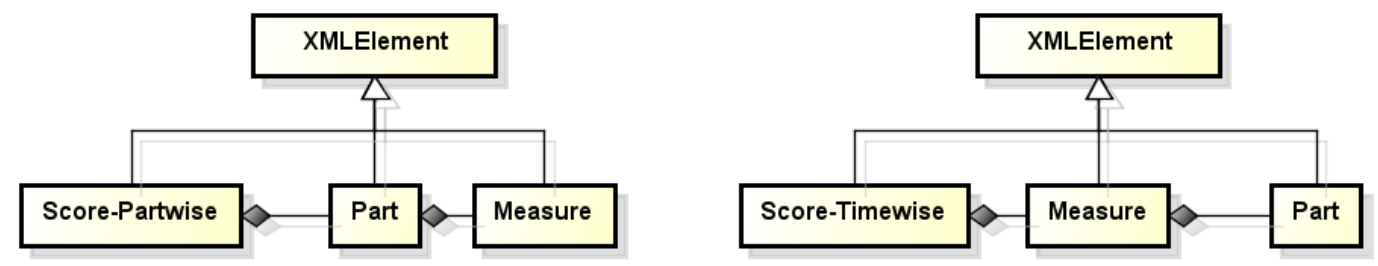

Figura 4.5: Comparação entre as variações partwise e timewise no formato MusicXML

O formato BMML, por sua vez, já possui uma estrutura bastante diferente, baseada na organização da informação musical em uma partitura braille. Neste formato privilegia-se a divisão da informação por partes (Encelle et al., 2009) (ver figura 4.6). Cada parte, em braille, equivale a um dos pentagramas de um instrumento e pode ser dividida por seções (algo equivalente ao sistema na notação tradicional), dependendo do padrão de leiaute utilizado. Na maioria das vezes, uma seção é definida por uma determinada quantidade de compassos.

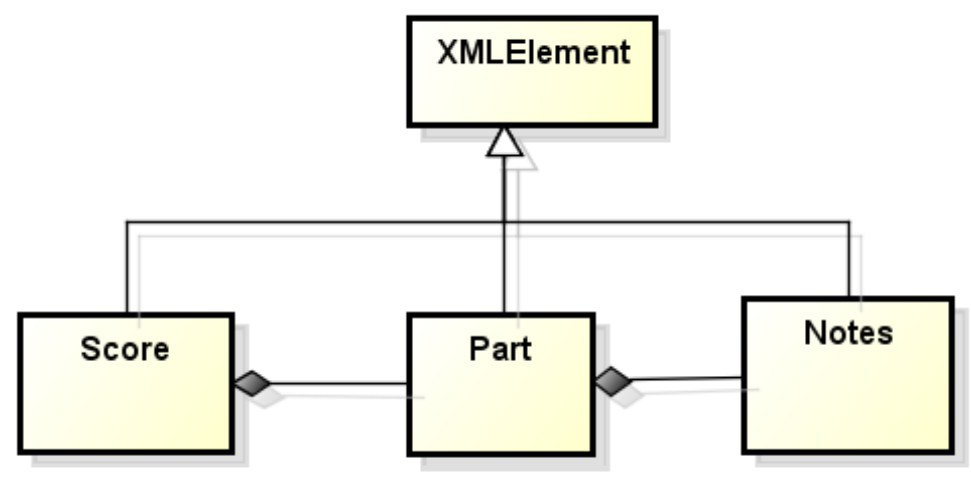

Figura 4.6: Modelo de representação da estrutura de alto nível do formato BMML

Em um primeiro momento pode-se supor que a estrutura do formato BMML, por ser concebida especificamente para representar a música através da musicografia braille, seria entendida como a mais adequada para inspirar o modelo do Delius. Contudo, conforme já mencionado, um dos fatores que devem ser considerados na concepção deste modelo de representação é garantir eficácia na navegação do usuário. A hierarquia da estrutura de alto nível do formato BMML relaciona-se fortemente com a diagramação do documento e sua divisão em páginas e sistemas. A navegação por um usuário que não disponha de recursos visuais em uma estrutura tal qual a apresentada pode ser bem pouco intuitiva. Além disso, deseja-se permitir que o usuário altere o padrão de leiaute do documento a qualquer momento. Novamente, promover uma navegação na informação musical baseada nesta estrutura significaria fazer com que o usuário tivesse que explorar o documento de diferentes formas para cada alteração do leiaute.

A estrutura do formato MusicXML Partwise é bastante intuitiva para os músicos: tem-se uma partitura, cada partitura tem seus instrumentos. Cada instrumento pode ter um ou mais pentagramas. Dentro de um pentagrama escreve-se notas e pausas, que são agrupadas dentro de pequenas porções temporais, que são os compassos propriamente ditos. Com base na hierarquia deste formato, portanto, será inspirada a estrutura do modelo de representação da informação musical no Delius. Ele viabiliza uma boa navegação ao mesmo tempo que permite que o usuário seja conduzido 
a um ponto de entrada de informação (onde ele adicionará ou removerá elementos musicais) sem preocupar-se, inicialmente, com a posição na página ou na folha na qual esta informação deve ser apresentada.

Com isso, também se cria uma situação de mais liberdade para que o programa use de rotinas de auto-formatação, que permitirão que o usuário possa testar uma série de leiautes diferentes em uma partitura, e até mesmo produzir recortes da partitura total (uma versão com apenas dois instrumentos, por exemplo) sem que a rediagramação seja um processo por demais trabalhoso.

Outro ponto relevante é a necessidade de produzir rapidamente uma representação visual e sonora dos elementos musicais ingressantes. Para isso, o programa precisa reconhecer os símbolos informados pelo usuário imediatamente após a entrada, o que significa passar por um processo inicial de compilação daqueles símbolos de modo a agregar no modelo os objetos abstratos que o representam.

Optou-se então por se entender o compasso como sendo o último nível dessa parte da estrutura; abaixo deste nível estarão os elementos de nível inferior, tratados igualmente como elementos de compasso. O principal objetivo é permitir que a tradução dos símbolos de entrada, para cada entrada que o usuário faça, seja minimizada, evitando a necessidade de releitura de todos os símbolos, desde o começo da partitura (ou mesmo daquele instrumento em particular) para cada novo símbolo produzido no documento (veja figura 4.7). Como fora visto anteriormente em 2.4, a duração das notas musicais depende de como elas podem completar a duração total do compasso, por sua vez regida pela fórmula de compasso vigente. Conforme será visto na próxima subseção, há motivos de complexidade computacional para que se evite este reprocessamento a cada entrada.

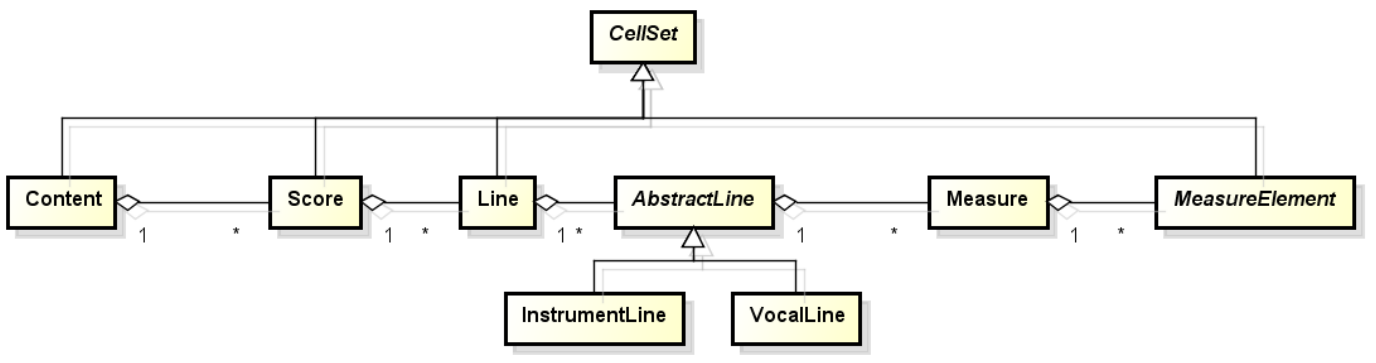

Figura 4.7: Modelo de representação da estrutura de alto nível do Delius

\section{Estrutura de baixo nível}

Este nível relaciona-se mais diretamente com as entradas fornecidas pelo usuário e os símbolos que produzirão conteúdo musical. Trata-se, portanto, dos elementos que não têm caráter estrutural e que são pertinentes dentro do domínio lógico. No caso do Delius, esta divisão é importante também pelos processos aos quais os integrantes desta parte do modelo são submetidos; em sua maioria, estes elementos de baixo nível serão produtos dos analisadores léxico e sintático, a partir dos comandos de entrada do usuário.

Todos os elementos musicais serão criados pelo usuário a partir da simulação de uma máquina Perkins (ver seção 2.2). Conforme citado na seção 2.6, os símbolos musicais são criados a partir de uma ou mais celas braille.

Para criar uma hierarquia consistente entre todos os elementos que compõem o modelo, foram criadas duas classes principais: as classes Cell e Cellset. A primeira representa a própria cela 
braille como um glifo dentro do modelo abstrato; a segunda representa um conjunto ou superconjunto de celas; Um objeto do tipo CellSet pode, portanto, conter uma coleção Cell ou mesmo uma coleção de CellSet. A classe Cellset é abstrata, de forma que deve ser estendida para que possa ser utilizada. Essa agregação recursiva permite criar uma estrutura em árvore onde nas folhas se teria os sinais braille e nos níveis superiores os significados atribuídos aos mesmos. É importante esclarecer que apenas a classe Cellset pode portar significado; a classe Cell é uma representação de um elemento do alfabeto braille, e por mais que uma instância desta classe, por si só, faça sentido dentro de um contexto, este sentido será atribuído ao objeto Cellset no qual tal instância estará contida (objeto-pai).

O compasso musical é representado pela classe Measure, que estende Cellset. Esta classe é importante por ser a classe que divide os dois níveis estruturais (baixo nível e alto nível). Ela possui duas coleções importantes; a primeira refere-se à coleção de CellSet que é característica da própria classe-base, conforme já foi detalhado, e é onde todos os elementos musicais daquele compasso serão ordenadamente armazenados. A segunda coleção é um buffer de celas, importante no processo de receber as entradas do teclado do usuário e convertê-las em símbolos musicais conforme isso seja possível, sendo portanto um agente intermediário entre a entrada do usuário e a primeira coleção aqui citada.

Esta primeira coleção da classe Measure receberá objetos do tipo MeasureElement. Esta é uma classe abstrata que dará origem a todos os elementos que podem ser adicionados a um compasso, como notas, pausas, ligaduras, sinais de indicação de mão, etc. A figura 4.8 ilustra o relacionamento entre estas classes.

Essa firna de estruturação da informação musical implementa o padrão de projeto Composite. Este padrão permite que objetos sejam compostos em estruturas de árvores para representar hierarquias do tipo parte-todo (Eric Freeman, 2004), possibilitando que objetos sejam tratados pelos programas tanto como coleções quanto como objetos individuais.

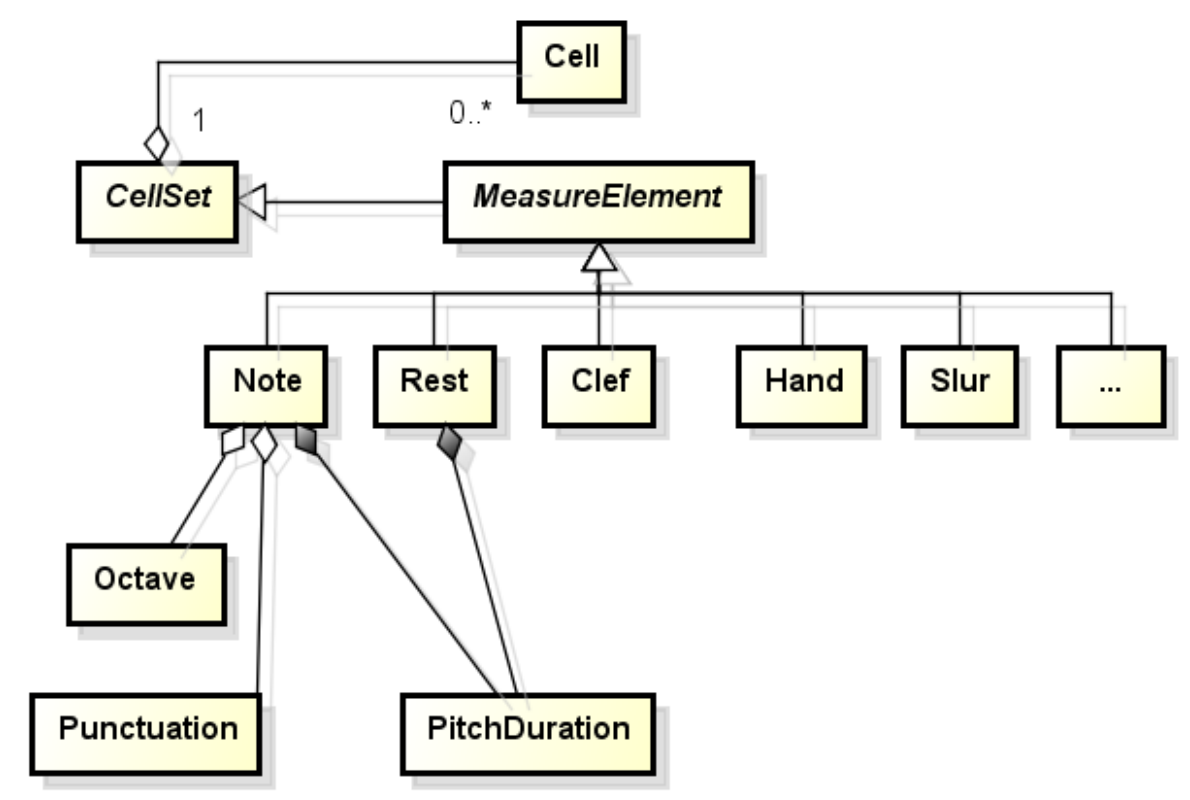

Figura 4.8: Modelo de representação da estrutura de baixo nível do Delius 


\section{Composição do modelo de representação}

A unificação das duas partes estruturais acima apresentadas resulta no modelo completo de representação. Esta estrutura final dará origem, portanto, ao objeto principal do programa, responsável por toda a informação musical produzida nele e pela integridade dos seus elementos. É também a parte a ser submetida aos processos de serialização e persistência, detalhados na seção 3.6.

Embora a estrutura final aqui definida seja o modelo representativo em sua totalidade, ele deve ser também interpretado como um modelo intermediário, no que se refere às entradas e saídas. Isso porque as informações a serem representadas em cada etapa do modelo devem ser tais que o modelo participe do processo de conversão entre os diversos possíveis formatos de entrada e saída do programa como uma linguagem intermediária. Isso significa que o modelo não busca aproximar-se simplesmente das entradas realizadas pelo usuário, mas também das saídas; por isso, as propriedades dos elementos musicais que estendem MeasureElement foram baseados nos objetos presentes nos modelos de saída, como os das definições do MusicXML e o abc4j. Isso significa que este modelo de representação será visto em determinados momentos como o objeto fundamental do programa, e em outros como um objeto intermediário entre a entrada do usuário e as saídas diversas. A figura 4.9 mostra a estrutura final, composta pelos dois níveis anteriormente apresentados.

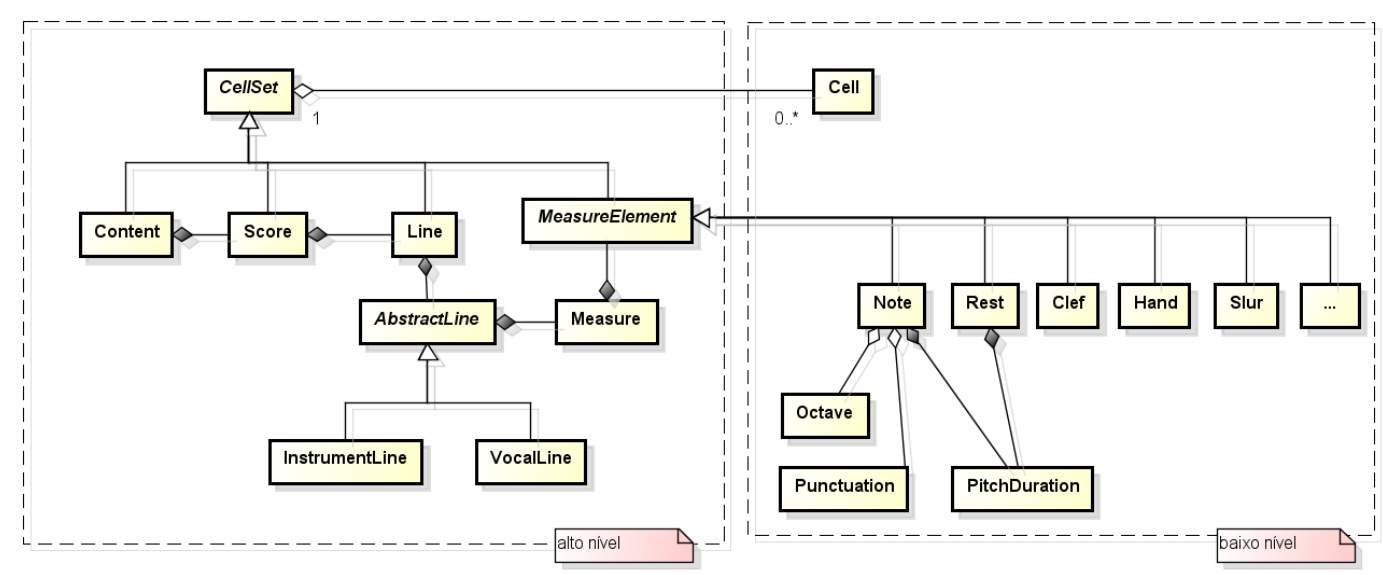

Figura 4.9: Modelo de representação completo

\subsection{Produção de informação musical no modelo de representação}

Esta seção trata da maneira com que a informação produzida pelo usuário, mediante a simulação da máquina Perkins no teclado do computador, é processada para o que o modelo seja corretamente alimentado com objetos que representem a informação musical. Para tanto, o usuário do programa deve situar-se no contexto de um compasso. Neste ponto, para cada entrada válida realizada, o programa executa os seguintes passos:

1. Interpreta a entrada e produz um objeto Cell;

2. Adiciona este objeto em na lista temporária (buffer) de celas do objeto de compasso ao qual pertence;

3. Processa o conteúdo do buffer do compasso no analisador léxico e sintático;

4. Recebe o retorno dos analisadores como objetos do tipo MeasureElement e os adiciona ordenadamente em uma coleção; 
5. Realiza o pré-processamento semântico dos símbolos:

(a) Organiza as celas do buffer dentro dos objetos recebidos (como folhas);

(b) Relaciona os elementos musicais por listas ligadas;

(c) Calcula a duração das notas baseadas na completude do compasso;

(d) Processa valores de parâmetros de símbolos baseados nos estados dos símbolos anteriores

6. Notifica outras instâncias da aplicação para que façam o redesenho das telas

7. Processa a descrição do símbolo inserido para notificação pelo leitor de tela

O processo automatizado de conversão entre linguagens é realizado, via de regra, mediante a construção e uso de compiladores. De forma simples, compiladores são programas que têm como objetivo ler um programa escrito em uma determinada linguagem de entrada (linguagemfonte) e transformá-lo em um programa equivalente escrito em outra linguagem (linguagem-alvo) (Aldred V. Aho, 1986). No caso em questão, embora o objetivo não seja produzir um programa a partir da linguagem de entrada, esta pode ser entendida como um conjunto de instruções musicais que deverão justamente ser traduzidas para uma outra linguagem onde tais instruções mantenhamse equivalentes, na medida do possível. Ademais, para se obter a linguagem-alvo é necessário que o texto fonte passe por uma série de etapas de reconhecimento, classificação e montagem que são características dos compiladores. São estas as fases importantes de um compilador (Aldred V. Aho, 1986; Neto, 1987):

- Análise léxica: consiste na análise dos caracteres e do alfabeto do texto do código fonte, gerando uma série de símbolos denominados tokens, que são apropriados para o manuseio pelo compilador na próxima etapa. O segmento responsável por essa etapa é geralmente chamado de lexer.

- Análise sintática: é a transformação dos símbolos analisados pela etapa anterior em uma árvore sintática que condiz com a gramática da linguagem de origem. Este segmento é chamado de parser.

- Análise semântica: é a interpretação do significado dos elementos dispostos na árvore sintática gerada pelo analisador sintático. Esta é a etapa onde há valoração dos símbolos da linguagem de origem.

- Código intermediário: é a criação de um código valorado e ordenado adequadamente para que a informação possa ser reescrita na linguagem destino.

A partir do código intermediário o compilador passa para a fase de montagem. No caso de programas de computador, é o momento em que se gera o objeto executável ${ }^{9}$.

\section{Processamento do buffer de celas do compasso}

Esta etapa é importante pela maneira com que o programa é reativo à entrada do usuário: a cada cela inserida, os analisadores léxico e sintático buscarão traduzi-la como um elemento do compasso ou agregá-la a algum elemento já existente. Portanto, ainda que esta cela integre em definitivo algum elemento do compasso, ela se mantém no buffer para que após uma próximo comando do usuário (inserção ou remoção de alguma outra cela) ela possa ser reinterpretada. A figura 4.10 ilustra este processo no aplicativo.

\footnotetext{
${ }^{9}$ Em algumas linguagens o código intermediário é o produto final do compilador, que será posteriormente processado por uma máquina virtual, que é um programa capaz de o ler e executar.
} 


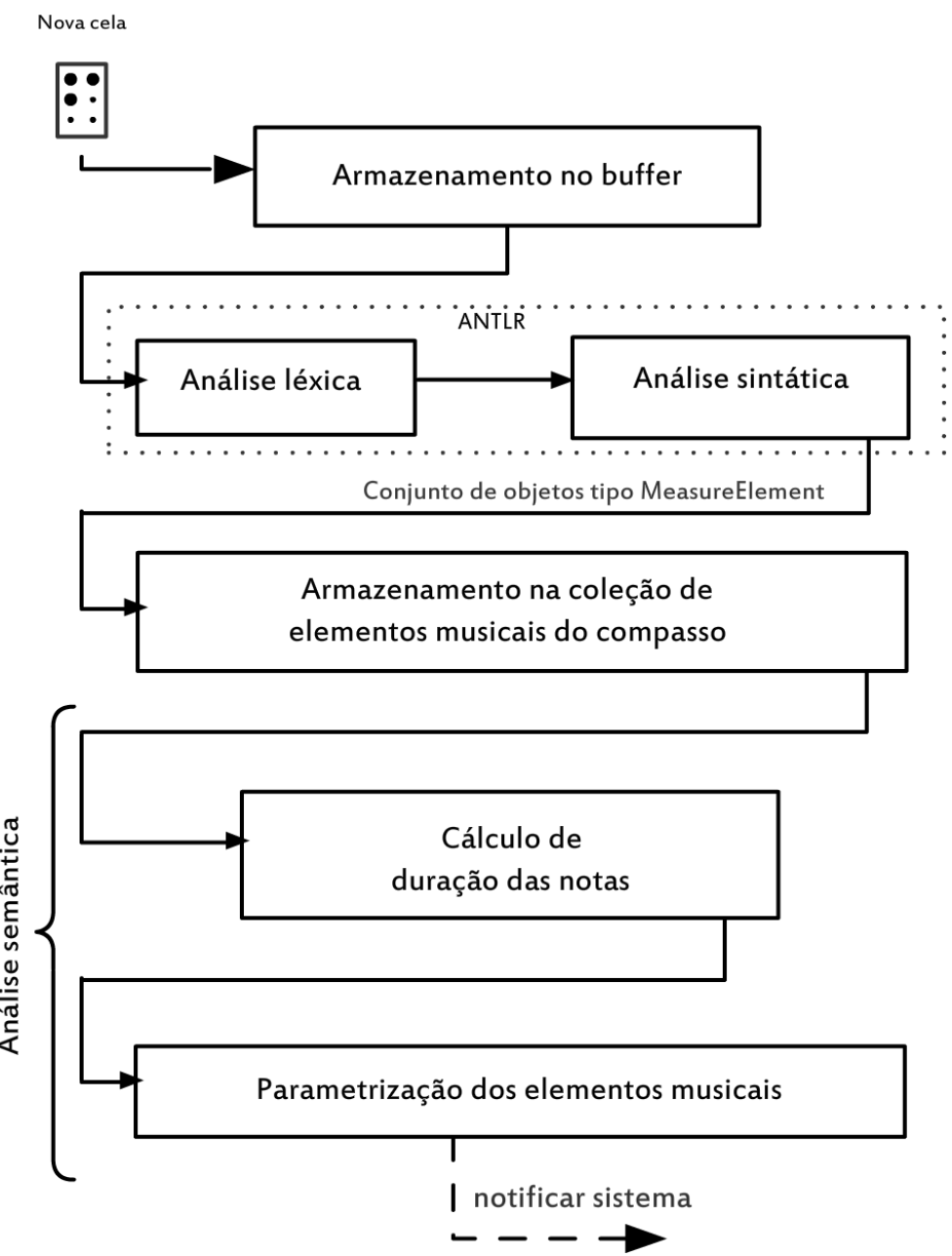

Figura 4.10: Etapas da tradução dos sinais braille para o modelo representativo.

\section{Análise léxica, sintática e semântica das celas}

As etapas de análise léxica e sintática são usuais no processo de tradução de linguagens. É o processo no qual verifica-se se uma dada cadeia de caracteres é ou não válida de acordo com uma linguagem formal. Esta linguagem, por sua vez, é definida através de um conjunto de símbolos por uma gramática formal. Numa primeira etapa, o analisador léxico responsabiliza-se por entender essa entrada como uma sequência de símbolos pertencentes à linguagem em questão. Estes símbolos são entendidos em dois níveis, sendo os símbolos terminais (tokens) aqueles mais elementares, que são indivisíveis, e os não-terminais como sendo composições dos símbolos terminais, formando o equivalente a palavras válidas dentro daquela linguagem. O analisador sintático, por sua vez, tem como responsabilidade verificar se os símbolos terminais organizam-se coerentemente formando sentenças, situação na qual é possível atribuir significado e valores aos símbolos terminais. Essa validação é feita por meio de um conjunto de regras sintáticas que também fazem parte da definição da linguagem em questão.

Tanto para as etapas de análise léxica e sintática como para a definição dos elementos da gramática (símbolos terminais e não-terminais, regras de geração), o aplicativo conta com um componente externo chamado ANTLR, que será tratado detalhadamente a seguir.

ANTLR ${ }^{10}$, acrônimo de ANother Tool for Language Recognition, é uma ferramenta para a construção de reconhecedores, interpretadores, compiladores e tradutores a partir de descrições

\footnotetext{
${ }^{10}$ http://www.antlr.org
} 
gramaticais. Esta ferramenta é capaz de produzir como saída classes e métodos, em diversas linguagens diferentes ${ }^{11}$ capazes de reconhecer e validar regras gramaticais criadas pelo usuário, sendo de fácil integração ao código fonte original. O ANTLR ainda conta com um plug-in de integração com o Eclipse IDE que contém uma série de ferramentas auxiliares para a criação de gramáticas, validação de regras e criação de casos de teste. Ele também permite a visualização em árvore dos símbolos terminais e não-terminais e dos diagramas de sintaxe, como pode ser visto nas figuras 4.11 e 4.12 .

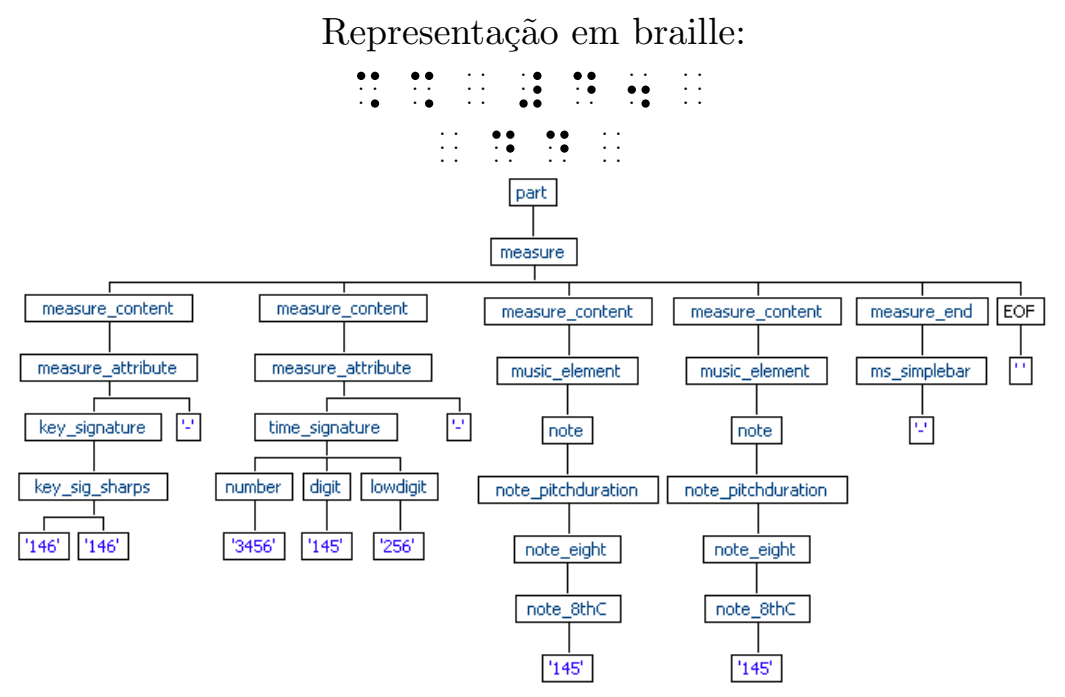

Figura 4.11: Exemplo de árvore sintática criada pelo ANTLR
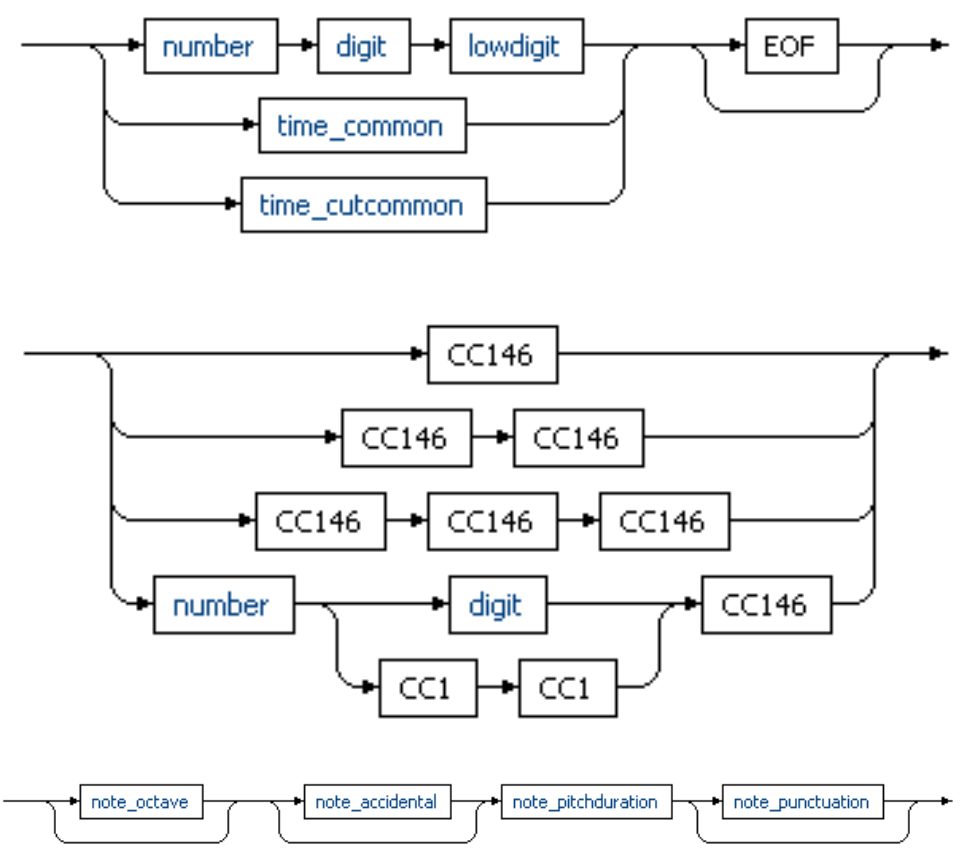

Figura 4.12: Exemplos dos diagramas de Sintaxe gerados pelo ANTLR

Com o uso desta ferramenta, o trabalho de interpretação das celas braille em símbolos musicais resume-se a buscar uma maneira de definir as regras (ou parte das regras) da musicografia braille de uma forma que o ANTLR seja capaz de as tratar. Dado um documento contendo os conjuntos

\footnotetext{
${ }^{11}$ até o início do ano de 2010 o sítio oficial do produto informa as seguintes: Ada95, ActionScript, C, C++, Csharp, Emacs ELisp, Java, Javascript, Python, Ruby, Perl, PHP, Oberon, Objective C e Scala
} 
de regras de geração da linguagem e os símbolos pertinentes à mesma (terminais e não-terminais), o ANTLR produzirá duas classes Java (para o caso em questão) com métodos já preparados para efetuar a varredura de uma cadeia de caracteres dentro da árvore sintática que é definida pelas regras anteriormente descritas. Este documento é escrito numa variação da forma de Backus-Naur (também conhecida por BNF). BNF (Backus-Naur Form) é uma metalinguagem para descrição de linguagens formais, publicada pela primeira vez no relatório de especificação da linguagem Algol 60 (Neto, 1987). Até hoje é amplamente usada, sobretudo para descrever sintaxe de linguagens de programação.

O apêndice D traz uma redução do documento que define as regras inicialmente implementadas no formato BNF. A versão completa do arquivo utilizado pelo ANTLR contém código Java mesclado, necessário para que a ferramenta crie um analisador sintático que retorne para a aplicação não só a árvore sintática das expressões válidas, mas um conjunto de objetos Cellset que possam prontamente ser utilizados pelo programa.

Uma das maiores vantagens em contar com esta ferramenta é a rapidez com que se inclui ou remove novas regras, dando ao programa maior capacidade de crescimento. Além disso, ele informa quando regras estão em conflito, facilitando a criação da gramática pela estruturação lógica dos elementos.

\subsection{Cálculo de duração das notas}

A musicografia braille possui algumas ambiguidades simbólicas que exigem uma completude mínima das sentenças musicais - particularmente no nível de compasso - para que seja possível estimar com segurança a forma correta de se entender tal sentença. Muito embora seja possível escrever o arquivo MusicXML com excesso ou falta de notas em um compasso, a representação visual e simultânea da entrada, desejada no aplicativo, será comprometida.

O problema a ser enfrentado diz respeito especificamente ao uso de um mesmo símbolo braille para representar duas durações diferentes, como pode ser visto na figura 2.4. Nessa figura vemos que os pontos superiores $(1,2,4,5)$ definem a altura das notas, e os inferiores $(3$ e 6$)$ definem a duração. Assim, ao fazer uso dos pontos 3 e 6 podemos estar representando semibreves ou semicolcheias; apenas o ponto 3 significa que a nota pode ser uma mínima ou uma fusa, e assim por diante. A idéia por trás desse pensamento é que as durações que usam uma mesma representação são muito distantes entre si (em cada grupo, o valor de maior duração é 16 vezes superior ao seu par), de forma que, nas configurações rítmicas usuais, só existiria uma interpretação possível para cada nota de modo a preencher corretamente o compasso. A seção 2.5 apresenta as regras de utilização de sinal de separação de valores das notas musicais que, embora seja adequado para resolver o problema de ambiguidade, não é exigido pelo MIMB quando a interpretação é óbvia para o leitor.

A compreensão da nota está, portanto, diretamente ligada ao preenchimento correto do compasso. A figura do compasso recebe então, em braille, um valor de importância diferenciado; sem a completude do compasso é impossível determinar com precisão o valor da duração das notas. Sob o ponto de vista humano, a prática e o conhecimento da obra ou do estilo norteiam a leitura de forma que essas questões de ambiguidade são na maioria dos casos rapidamente resolvidas, e apenas alguns excertos carecem de uma leitura mais cuidadosa. Computacionalmente, porém, é necessário verificar matematicamente a completude do compasso, ou seja, verificar se a soma das durações das notas perfaz a duração total do compasso conforme a fórmula de compasso vigente.

Inicialmente, por questões de eventuais arredondamentos de dízimas periódicas, a duração das notas musicais será representada, na aplicação, em forma de fração. Para isso foi criada a classe Duration, que representará o tempo das notas em numerador e denominador. Por convenção, 
adotamos a semibreve como referência de unidade temporal.

\begin{tabular}{|c|c|c|c|c|}
\hline Braille & Símbolo & Duração & Numerador & Denominador \\
\hline :: $:$ & 101 & breve & 2 & 1 \\
\hline$\because:$ & $\mathbf{o}$ & semibreve & 1 & 1 \\
\hline$\because:$ & d & mínima & 1 & 2 \\
\hline$\because:$ & . & semínima & 1 & 4 \\
\hline$\because:$ & .) & colcheia & 1 & 8 \\
\hline$\because:$ & . & semicolcheia & 1 & 16 \\
\hline$\because:$ & S & fusa & 1 & 32 \\
\hline$\because:$ & A & semifusa & 1 & 64 \\
\hline$\because:$ & 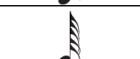 & quartifusa & 1 & 128 \\
\hline
\end{tabular}

Tabela 4.2: Representação da duração das notas

Para que seja possível estimar o valor de duração das notas, consideraremos os elementos invariantes especificados no manual:

1. Não é possível dois elementos de igual símbolo braille e com diferentes durações serem dispostos lado a lado sem um sinal de separação de valores.

2. Os sinais de valores maiores definem sumariamente os valores das notas conseguintes de acordo com as primeiras quatro linhas da tabela 4.2 e os valores menores de acordo com as quatro últimas linhas.

3. Todos os símbolos de notas representam duas categorias de duração diferentes onde os valores menores são 16 vezes menor do que os valores maiores.

4. Por conta dos agrupamentos, os símbolos que se assemelham às colcheias também podem representar o valor de duração especificado pela nota que as antecede, cujo valor deve ser obrigatoriamente menor do que o de colcheia, já que notas de duração superior não se agrupam.

Assim, dado um compasso preenchido com notas, o primeiro passo para se estimar os valores das notas é agrupá-las em subconjuntos por semelhança. Considere a seguinte sentença:

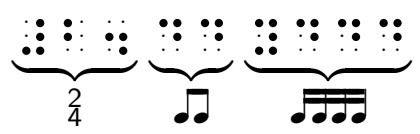

Primeiramente, elas serão agrupadas em blocos de afinidade; embora não seja possível ainda precisar valores, é possível, pelas proposições enumeradas acima garantir que notas (e pausas) consecutivas, com a mesma grafia de duração, realmente possuem a mesma duração.

Consideremos o conjunto $C$ de notas totais no compasso, divididas em $k$ subconjuntos de $n_{k}$ notas de duração $d_{k}$, e seja $f$ a fração correspondente à fórmula de compasso vigente. Sabe-se que a completude do compasso é garantida quando a soma da duração das notas e pausas for igual à fração correspondente à fórmula de compasso, ou seja, quando $\sum_{i=1}^{k} n_{i} d_{i}=f$. Assim, na sentença acima temos o seguinte agrupamento: 


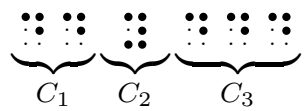

No exemplo acima, $f=\frac{2}{4}$, de forma que $n_{1} d_{1}+n_{2} d_{2}+n_{3} d_{3}=\frac{2}{4}$, ou seja,

$$
\left\{\begin{array}{l}
2 d_{1}+d_{2}+3 d_{3}=\frac{2}{4}, \text { onde } \\
d_{1}=\frac{1}{8} \text { ou } \frac{1}{128} \\
d_{2}=\frac{1}{16} \text { ou } 1 \\
d_{3}=\frac{1}{8} \text { ou } \frac{1}{128} \text { ou } \frac{1}{16} ;
\end{array}\right.
$$

A solução deste problema pode ser obtida através de uma árvore de decisão com as possibilidades de soma existentes. Porém, essa solução tem custo exponencial no pior caso $\left(3^{k}\right.$ alternativas caso haja os três valores possíveis para todo $\left.d_{k}\right)$. Embora as instâncias sejam sempre pequenas $(k \geq$ 10 seria um caso muito raro), alternativas mais eficientes de se resolver o problema deverão ser investigadas.

\subsection{Questões em aberto relativas ao processo de tradução}

Esta seção tratará de alguns elementos musicais que não foram implementados no trabalho até o presente momento, seja por sua complexidade ou por exigirem maior tempo ou análise. É importante, porém, mencioná-los aqui, para que possam ser oportunamente discutidos em trabalhos futuros.

\section{Quiálteras}

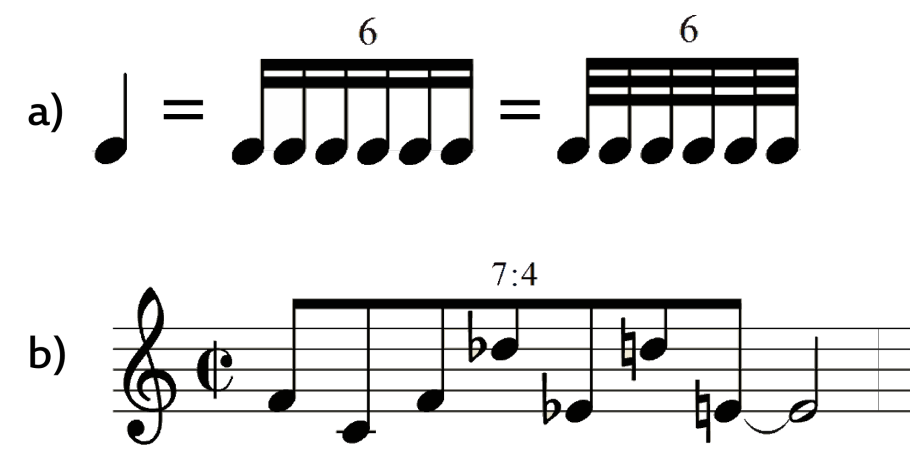

Figura 4.13: Detalhes sobre a notação de quiálteras na grafia musical tradicional.

O entendimento de quiálteras pelo programa torna-se bastante mais complicado do que o esperado inicialmente pela soma de dois fatores: a impossibilidade de se conhecer a priori a duração real das notas do compasso, conforme mencionado acima, e a ausência de um caractere terminador para finalizar o segmento braille que está sendo alterado pelo sinal de quiáltera (ver o caso do sinal de tercina, na seção 2.4). Quiálteras são grupos de notas empregados com maior ou menor valor do que normalmente representam. Quiálteras regulares são aquelas onde as notas têm a mesma duração; quiálteras irregulares, são aquelas formadas por notas com valores desiguais. Define-se por quiálteras aumentativas aquelas que permitem tocar mais notas no mesmo espaço de tempo, e as diminutivas aquelas que permitem tocar menos notas no mesmo espaço de tempo. Na musicografia tradicional em tinta, o critério de escolha da figura para a representação da quiáltera (aumentativa ou diminutiva) depende da maior proximidade ente o número de notas da quiáltera e o número de notas da subdivisão normal (Med, 1996). É interessante perceber, por essa regra, que uma semínima dividida em sextinas regulares pode ser representada de duas maneiras, como mostra a ilustração A da figura 4.13, que podem ser grafadas como semicolcheias ou fusas; no primeiro caso, interpreta-se como uma quiáltera aumentativa, enquanto que no segundo caso trata-se de uma quiáltera diminutiva. Em alguns casos, certos compositores optam por usar outra notação, indicando claramente 
quantas notas são tocadas no tempo de quantas outras, como mostra a ilustração B da figura 4.13.
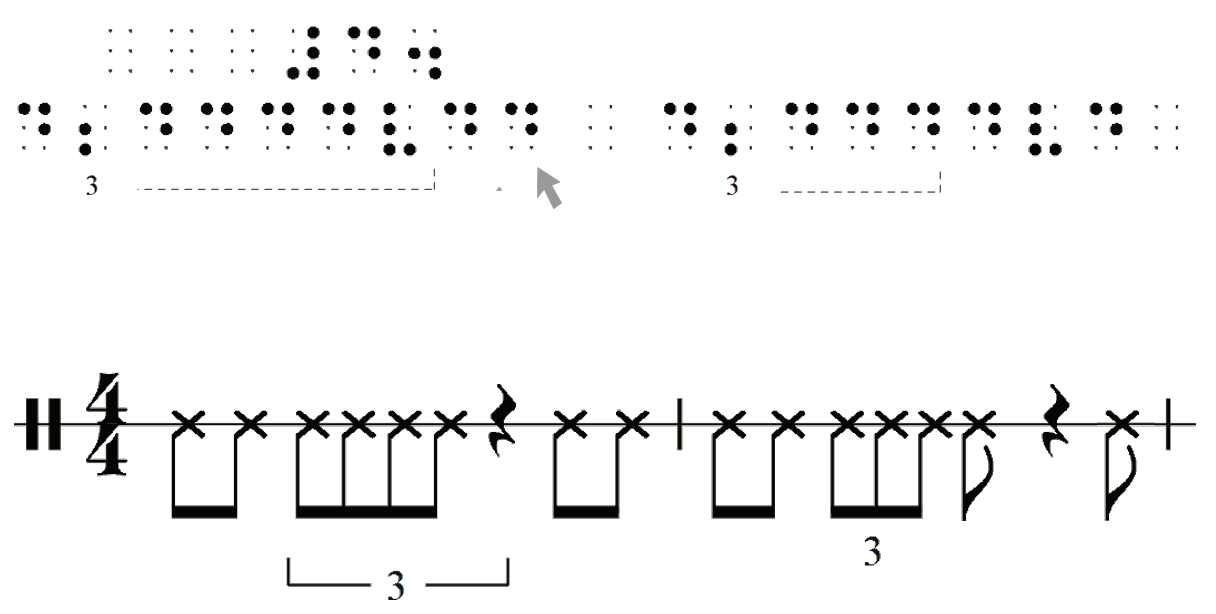

Figura 4.14: Comparação do emprego de tercinas nas grafias musicais.

No braille, no entanto, informa-se apenas o valor das quiálteras, sem nenhuma informação mais clara de quais são as notas realmente afetadas por elas. A situação apresentada pela figura 4.14 mostra uma situação clara onde há o emprego da tercina em duas situações muito diferentes, as quais se diferem unicamente pela quantidade de símbolos de notas no compasso (a saber, uma colcheia $\because:$ no final do primeiro compasso, apontada pela seta cinza). No primeiro compasso, o sinal de tercina refere-se realmente a três semínimas; por tratar-se de quiáltera irregular, subdivide-se este valor em quatro colcheias e uma semicolcheia. No segundo caso, o sinal de tercina diz respeito às três colcheias subsequentes apenas. Deste modo, a interpretação correta das notas que integram as quiálteras (principalmente nos casos de quiálteras irregulares) é, da mesma forma que a duração das notas, dependente da quantidade de notas presentes no compasso, presumindo um compasso corretamente completo. Ademais, sendo a quiáltera justamente um modificador da duração das notas, cria-se uma espécie de dependência cíclica entre estes elementos. Percebe-se, porém, que na figura 4.14 só há uma situação possível para cada um dos casos, o que certamente permite encontrar a solução do problema. No entanto, a modificação necessária na árvore de decisão apresentada na seção 4.5 para resolver o problema a prejudica enormemente com relação à sua eficiência; além desta árvore de decisão ter de testar todos as durações possíveis, ela precisará testar simultaneamente (e subordinadamente à esse primeiro teste) todos os agrupamentos possíveis de notas até encontrar uma situação de completude do compasso. Para o escopo deste trabalho, não será proposta nenhuma solução para o problema, deixando-o em aberto para trabalhos futuros.

\section{Linhas vocais e cifras}

As linhas vocais que acompanham uma melodia (tratadas na seção 2.8) são uma parte muito importante e desejada como implementação do Delius, no entanto deverão figurar em versões futuras, dado que ainda é necessário consolidar as metodologias de navegação e acesso à informação propostas por este trabalho para que se proponha a implementação adequada. Isso ocorre porque as linhas vocais são escritas, dentro das seções (blocos) das partituras em braille, alternadamente com as linhas melódicas. Porém, as linhas melódicas compõem estas seções, via de regra, por um determinado número de compassos, o que não ocorre com as linhas vocais, que integram estes blocos de acordo com as notas as quais se referem. Dessa forma, uma das propostas estudadas até o presente momento é que haja um ambiente paralelo para entrada de texto, onde seja possível fazer a associação e o acompanhamento das sílabas juntamente com as notas. A diagramação de texto e melodia poderia, dessa forma, ser feita automaticamente, sem que haja necessidade do usuário posicionar o texto junto às linhas melódicas. Este seria também o caso da indicação de cifras, ge- 
ralmente posicionadas acima das notas ou acordes.

\section{Sinais de repetição}

Os sinais de repetição aqui mencionados são aqueles próprios da musicografia braille, sem equivalência na grafia em tinta, descritos no final da seção 2.4. A dificuldade de implementação vem da ausência de formalidade quanto ao uso do recurso. O próprio manual de musicografia braille coloca que "seu uso exige intuição e uma boa formação musical". De fato, este sinal pode representar tanto uma repetição de toda a sentença musical que o antecede, dentro do mesmo compasso, como apenas algumas notas desta sentença, cuja repetição caracterizaria um ostinato. Este sinal, porém, é um recurso extremamente importante para a musicografia braille, por facilitarem a leitura e a memorização, além de poupar espaço; por esses motivos, é desejado que, tão logo seja possível, o mesmo venha a integrar o conjunto elementos compreendidos pelo aplicativo.

\subsection{Conclusão do capítulo}

Este capítulo tratou da metodologia utilizada para a definição do modelo de representação utilizado pela aplicação e a forma com o qual é preenchido a partir das entradas realizadas pelo usuário utilizando no teclado do computador um emulador da máquina Perkins. O conjunto de classes e seus respectivos métodos deste modelo serão o alicerce para todas as conversões entre linguagens de representação musical que venham a ser implementadas pelo programa, dando origem portanto ao componente principal do mesmo.

Também foi realizada uma discussão sobre a divisão da representação simbólica musical em aspectos ou domínios. A partir disso, realizou-se uma comparação entre diversos modelos de representação simbólica musical existentes, versando sobre as especificidades de cada um e da sua relação com estes aspectos.

Também foi discutido, neste capítulo, questões específicas da tradução de informação musical partindo da grafia braille, como o caso da determinação da duração das notas dentro de um compasso e dificuldades na tradução de certos símbolos, como as quiálteras e os sinais de repetição. 


\section{Capítulo 5}

\section{Análise do aplicativo e discussão}

\subsection{Introdução}

Este capítulo buscará avaliar o resultado do desenvolvimento apresentado nos capítulos anteriores, investigando as escolhas feitas e as decisões de implementação tomadas, a partir de experiências práticas. Será objetivo desta análise verificar se o aplicativo realmente aproxima-se de seu objetivo inicial, ou seja, se poderá atuar como uma ferramenta de apoio na relação entre alunos cegos e professores videntes.

Avaliar a real eficácia do aplicativo dentro do cenário acima mencionado é certamente uma tarefa de longo prazo. A etapa atual de análise visa observar os primeiros passos dados em direção a este objetivo, discutindo as escolhas tomadas durante o processo de desenvolvimento e distinguindo os pontos que se aproximam das metas estabelecidas e os pontos que carecem de reformulação ou melhorias. Ademais, essa etapa também possibilitou um contato mais próximo com potenciais usuários, proporcionando não só um conhecimento mais abrangente de suas necessidades como também despertando, por parte dos mesmos, a atenção para o projeto que está sendo realizado.

A análise do aplicativo foi feita em duas partes principais. A primeira parte consiste em uma avaliação da usabilidade e da experiência do usuário, onde voluntários foram submetidos a uma situação de uso do programa através de tarefas específicas; ao final, estes voluntários eram submetidos a uma entrevista, onde davam seus pareceres com relação a questões do programa que foram observadas durante sua exploração. Foi realizada então uma análise destes dados a fim de caracterizar as tendências do posicionamento dos usuários entrevistados.

A segunda parte da análise busca avaliar a qualidade do programa na tarefa de conversão entre as linguagens. Para tanto, alguns testes de transcrição foram realizados com base em materiais didáticos reais, utilizados atualmente em aulas de musicografia braille. Os resultados são comparados e analisados.

\subsection{Análise de usabilidade e da experiência do usuário}

Nesta primeira etapa de avaliação do software, um experimento com usuários reais foi preparado, buscando entender possíveis dificuldades experimentadas pelos mesmos, considerando o atual estágio de desenvolvimento do programa. Para tanto, duas tarefas simples de uso prático do programa foram idealizadas. Tais tarefas não tinham como objetivo qualificar a aptidão do usuário com relação ao uso do programa, mas sim buscar situar o entrevistado dentro de uma experiência de uso plausível, que o incentivasse a explorar os recursos do programa a fim de alcançar os objetivos propostos. A qualidade do material musical produzido pelos usuários, sob a perspectiva estética, é 
portanto irrelevante para a presente análise.

Um questionário foi preparado para colher esta experiência de uso. Suas perguntas são divididas em alguns grupos principais. O primeiro grupo busca caracterizar o perfil do entrevistado, classificando-o por idade, possíveis necessidades especiais, grau de instrução e sua experiência com informática e com as grafias musicais. Em um segundo momento, o questionário registra algumas informações sobre as tarefas realizadas, como o tempo gasto em cada uma, erros encontrados, grau de dificuldade e sucesso obtido. O terceiro grupo de questões busca explorar a experiência de forma geral, avaliando os recursos de navegação e de produção musical dentro do ambiente do programa, a frequência com que o usuário se perde ou fica confuso com a informação prestada, a qualidade dos recursos visuais e sonoros que compõem a interface do usuário e a qualidade das transcrições realizadas. A última parte do questionário faz uma avaliação geral do programa em medidas mais subjetivas, como satisfação geral, produtividade e configurabilidade. Nesta última parte também estão presentes algumas questões dissertativas, para o usuário apontar sua opinião sobre possíveis usos do programa e melhorias necessárias. A maioria das questões tinham a resposta esperada dentro de escalas Likert (Likert, 1932) de cinco pontos, sendo que para cada caso é especificado o valor semântico dos pontos máximos e mínimos (ex.: Pouco consistente/muito consistente, Muito difícil, muito fácil). O questionário completo está disponível no apêndice A.

As entrevistas foram realizadas individualmente, numa duração aproximada de 1 hora por participante. A única exigência para a seleção de voluntários era que o indivíduo afirmasse possuir conhecimento em musicografia braille, não sendo necessário portanto experiência em computação ou com programas musicais.

\section{Organização dos dados obtidos}

A colheita dos dados foi realizada no ambiente mais adequado para cada um dos entrevistados, muitas vezes na casa dos mesmos. Da mesma forma, foi permitido que o usuário escolhesse entre utilizar seu próprio computador ou um computador que esteve disponível para esta finalidade. Pelo motivo de não haver um ambiente padrão para a aplicação dos testes, entre outros motivos, os dados colhidos passaram por alguma depuração antes do início das análises exploratórias, conforme mencionado abaixo:

- Inicialmente era esperado que se pudesse explorar os dados levando em consideração a acuidade visual dos entrevistados dividida em três grupos: cegueira total, visão subnormal e visão normal. Contudo, por apenas um entrevistado apresentar visão subnormal, o fator acuidade visual foi dividido entre dois grupos apenas, "deficiente visual" e "visão normal".

- Os números relativos à tarefa 0 (instalação do software) foram descartados para esta análise, pois a instalação do programa não foi necessária em todos os casos, além de ter produzido exatamente o mesmo resultado em todas as situações (menos de 1 minuto, nenhum problema encontrado, fácil instalação e total sucesso obtido). As questões que perguntavam se houve necessidade de recomeçar as tarefas também foram descartadas para esta análise exploratória, pois o resultado foi sempre negativo para todas as tarefas.

- A questão que pede uma nota geral sobre configurabilidade não participou da maioria dos cruzamentos de dados, pois foram obtidas poucas respostas, já que as situações de uso não exploravam todos os recursos de configuração da ferramenta. Para que esta questão pudesse ser levada em consideração seria necessário que os usuários tivessem um maior tempo de contato com o software; Nenhum dos usuários entrevistados teve experiência prévia com a ferramenta. 
- As experiências de impressão e comparação não puderam ser feitas em todas as entrevistas por ausência de equipamento necessário (impressoras, principalmente). As informações colhidas estão presentes nos relatórios de frequência das respostas mas não foram utilizadas nos cruzamentos realizados.

\section{Perfil dos entrevistados}

Das respostas dadas às questões referentes ao perfil dos entrevistados, discriminadas nas tabelas 5.1 e 5.2, pode-se extrair de forma trivial as seguintes afirmações a respeito da amostra:

\begin{tabular}{lcrll}
\hline & Usuário & Faixa Etária & Acuidade Visual & Grau de Instrução \\
\hline \hline & U1 & 70 & Visão normal & Ensino Médio \\
& U2 & 30 & DV - Nenhuma visão & Superior \\
U3 & 40 & DV - Baixa visão & Ensino Médio \\
& U4 & 50 & DV - Nenhuma visão & Pos-graduação \\
& U5 & 20 & DV - Nenhuma visão & Ensino-médio \\
& U6 & 40 & Visão normal & Superior \\
& U7 & 20 & Visão normal & Superior \\
& U8 & 30 & Visão normal & Superior \\
N & U9 & 20 & DV - Nenhuma visão & 9 \\
Média & 9 & 9 & 9 & \\
Mediana & & 35,56 & & \\
Desv.Padrão & & 16,00 & & \\
Variância & & 277,77 & & \\
\hline
\end{tabular}

\begin{tabular}{clll}
\hline Usuário & S.O. que utiliza & Leitores de tela utilizados & $\begin{array}{l}\text { Softwares utilizados para escre- } \\
\text { ver música }\end{array}$ \\
\hline \hline U1 & Windows & & Nenhum \\
U2 & Windows & JAWS & Nenhum \\
U3 & Windows & NVDiBraille \\
U4 & Windows & & Sonar, Lime Aloud, GoodFeel, \\
& Windows & JAWS, NVDA & CakeTalking, Finale \\
U6 & Windows & JAWS & MusiBraille \\
U7 & Windows, Linux & MusiBraille, Braille Fácil & Encore, Sibelius, MusiBraille \\
U8 & Windows & NVDA, Virtual Vision, Voice- & Nenhum \\
U9 & Windows, Mac & Over & \\
& & & Finale \\
\hline \hline
\end{tabular}

Tabela 5.1: Perfil dos entrevistados

1. Todos possuem algum conhecimento de musicografia braille, sendo este o único pré-requisito estipulado para a seleção de usuários aptos a participar da entrevista.

2. Todos os entrevistados possuem pelo menos grau de instrução do Ensino Médio completo.

3. A grande maioria dos usuários entrevistados utiliza sistema operacional Windows.

4. Não há unanimidade entre os usuários que fazem uso de softwares leitores de tela; cada usuário utiliza um ou mais leitores diferentes, de acordo com preferências pessoais, seja do som produzido pelo leitor ou mesmo por sua habilidade de integração com outros programas.

5. A faixa etária dos entrevistados é bastante abrangente (22 a 75 anos; média 35,56; desvio padrão 16,66)

\section{Análise exploratória: busca por possiveis grupos de usuários e correlações}

Inicialmente, extraiu-se tabelas de resumo de todas as questões onde as respostas fossem baseadas em valores ordinais (ver tabela 5.3 e 5.4 ) e seus respectivos histogramas (ver apêndice apêndice A). Foram entendidas como variáveis independentes as questões relativas ao perfil do 


\begin{tabular}{lrrrr}
\hline & Usuário & Proficiência em mus.brl. & Proficiência em mus. tinta & Proficiência em informática \\
\hline \hline & U1 & 3 - avançado & 3 - avançado & 1 - básico \\
& U2 & 2 - intermediário & 0 - nenhum & 1 - básico \\
& U3 & 2 - intermediário & 2 - intermediário & 2 - intermediário \\
& $\mathrm{U} 4$ & 3 - avançado & 2 - intermediário & 2 - intermediário \\
& $\mathrm{U} 5$ & 2 - intermediário & 0 - nenhum & 2 - intermediário \\
& $\mathrm{U} 6$ & $3-3$ - avançado & 3 - avançado & 2 - intermediário \\
& $\mathrm{U} 7$ & $2-$ intermediário & 3 - avançado & 2 - intermediário \\
& $\mathrm{U} 8$ & $3-3$ - avançado & 3 - avançado & 2 - intermediário \\
& $\mathrm{U} 9$ & $2-$ intermediário & 3 - avançado & 2 - intermediário \\
\hline N & 9 & 9 & 9 & 9 \\
Média & & 2,44 & 2,00 & 1,78 \\
Mediana & & 2,00 & 2,00 & 2,00 \\
Desv.Padrão & & 0,527 & 1,225 & 0,441 \\
Variância & & 0,278 & 1,500 & 0,194 \\
\hline
\end{tabular}

\begin{tabular}{lcrrr}
\hline & Usuário & Conforto com mus.brl. & Conforto com mus. tinta & Conforto com informática \\
\hline \hline & $\mathrm{U} 1$ & 4 & 5 & 5 \\
& $\mathrm{U} 2$ & 4 & 1 & 2 \\
& $\mathrm{U} 3$ & 5 & 1 & 5 \\
& $\mathrm{U} 4$ & 5 & 1 & 3 \\
& $\mathrm{U} 5$ & 5 & 1 & 5 \\
& $\mathrm{U} 6$ & 5 & 5 & 5 \\
& $\mathrm{U} 7$ & 4 & 5 & 5 \\
& $\mathrm{U} 8$ & 4 & 5 & 5 \\
& $\mathrm{U} 9$ & 3 & 1 & 9 \\
& 9 & 9 & 9 & 4,44 \\
$\mathrm{~N}$ & & 4,33 & 2,78 & 5,00 \\
Média & & 4,00 & 1,00 & 1,130 \\
Mediana & & 0,707 & 2,108 & 1,278 \\
Desv.Padrão & & 4,500 & 444 & 5 \\
Variância & & & & 5 \\
\hline
\end{tabular}

Tabela 5.2: Conhecimento dos entrevistados em musicografia braille, musicografia em tinta e informática

usuário, como idade, grau de instrução, acuidade visual, etc., e variáveis dependentes aquelas que tratam da experiência que o entrevistado teve com o Delius. Garantiu-se que a os valores mínimos e máximos das respostas estivessem dispostos ordenadamente, considerando que os valores menores representariam valores menos "desejados", que indicassem possível depreciação de algum recurso ou medida do programa, enquanto que os valores maiores indicariam uma possível apreciação ou satisfação para com o mesmo. Dessa forma, também é possível olhar os histogramas no apêndice A e perceber as tendências mais subjetivamente.

Percebeu-se que, de modo geral, as respostas foram bastante positivas, geralmente com média acima de 3. Não é possível, porém, inferir com base nestes valores que o programa já atingiu um grau de maturidade satisfatório: os valores de média para amostras populacionais desta grandeza (apenas nove usuários) são bastante sensíveis, sendo que uma resposta a mais talvez fosse suficiente para modificá-los drasticamente. Além disso, os voluntários foram entrevistados pelo próprio autor, o que pode aumentar os valores das respostas para níveis mais positivos. Outro fator que também deve ser considerado é que o programa promete algo que vai fortemente de encontro a uma expectativa da maioria dos entrevistados; havendo poucas opções disponíveis para o mesmo fim é de se esperar que qualquer contribuição seja bem recebida.

Ainda assim, muita informação ainda pode ser extraída dos dados colhidos. O desvio padrão é um bom indicador para tentar entender se os entrevistados, para cada resposta, estão em acordo ou desacordo. A convergência das opiniões produz uma curva normal mais alta e estreita (ver histograma de "Velocidade comparando ao uso de regletes"), enquanto que opiniões divergentes produzem uma curva baixa e esparsa (ver histograma de "Facilidade com que se insere conteúdo musical na partitura").

Analisando as frequências das respostas, considerou-se a possibilidade de haver relações entre 
Dados das tarefas

\begin{tabular}{|c|c|c|c|c|c|c|c|c|c|c|}
\hline & \multicolumn{2}{|c|}{$\mathrm{N}$} & \multirow[b]{2}{*}{ Mean } & \multirow[b]{2}{*}{ Median } & \multirow[b]{2}{*}{ Mode } & \multirow[b]{2}{*}{ Std. Deviation } & \multirow[b]{2}{*}{ Variance } & \multirow[b]{2}{*}{ Range } & \multirow[b]{2}{*}{ Minimum } & \multirow[b]{2}{*}{ Maximum } \\
\hline & Valid & Missing & & & & & & & & \\
\hline T1 - Tempo gasto ( $\mathrm{min})$ & 7 & 2 & 3,71 & 4,00 & $2^{a}$ & 1,496 & 2,238 & 4 & 2 & 6 \\
\hline T1 - Grau de dificuldade (fácil/difícil) & 7 & 2 & 4,57 & 5,00 & 5 & ,787 & ,619 & 2 & 3 & 5 \\
\hline $\begin{array}{l}\mathrm{T} 1 \text { - Grau de sucesso obtido } \\
\text { (instatisfatório / satisfatório) }\end{array}$ & 7 & 2 & 4,57 & 5,00 & 5 & ,787 & ,619 & 2 & 3 & 5 \\
\hline T2 - Grau de dificuldade (fácil/difícil) & 9 & 0 & 3,78 & 3,00 & 3 & 972 & ,944 & 2 & 3 & 5 \\
\hline $\begin{array}{l}\text { T2 - Grau de sucesso obtido } \\
\text { (instatisfatório / satisfatório) }\end{array}$ & 9 & 0 & 4,33 & 4,00 & $4^{a}$ & ,707 & ,500 & 2 & 3 & 5 \\
\hline
\end{tabular}

a. Existem múltiplas modas. O menor valor é o exibido.

Questões sobre edição

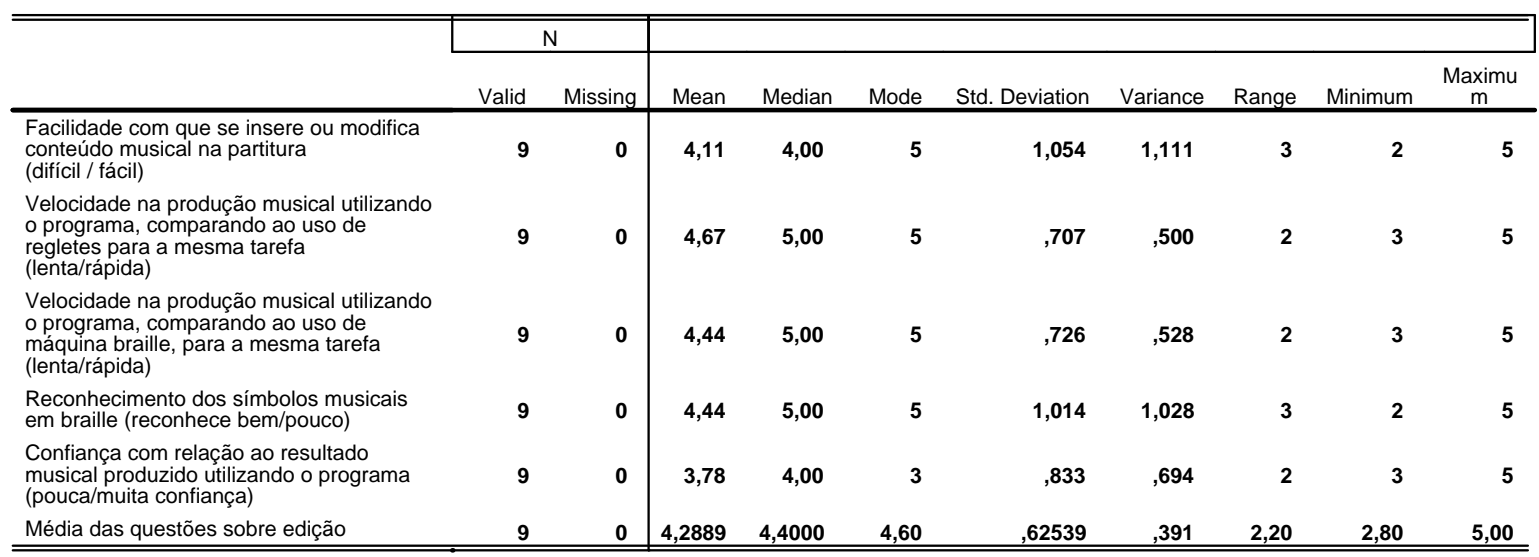

Questões sobre navegação

\begin{tabular}{|c|c|c|c|c|c|c|c|c|c|c|}
\hline & \multicolumn{2}{|c|}{$\mathrm{N}$} & \multirow[b]{2}{*}{ Mean } & \multirow[b]{2}{*}{ Median } & \multirow[b]{2}{*}{ Mode } & \multirow[b]{2}{*}{ Std. Deviation } & \multirow[b]{2}{*}{ Variance } & \multirow[b]{2}{*}{ Range } & \multirow[b]{2}{*}{ Minimum } & \multirow[b]{2}{*}{ Maximum } \\
\hline & Valid & Missing & & & & & & & & \\
\hline $\begin{array}{l}\text { Velocidade de aprendizado/entendimento } \\
\text { dos comandos de navegação } \\
\text { (lenta/rápida) }\end{array}$ & 9 & 0 & 3,89 & 4,00 & 3 & ,928 & ,861 & 2 & 3 & 5 \\
\hline $\begin{array}{l}\text { Frequência com que o usuário se perde } \\
\text { durante a navegação } \\
\text { (raramente/frequentemente) }\end{array}$ & 9 & 0 & 3,22 & 3,00 & 4 & ,833 & ,694 & 2 & 2 & 4 \\
\hline $\begin{array}{l}\text { Velocidade com que o usuário alcança } \\
\text { posições desejadas } \\
\text { (lentamente/rapidamente) }\end{array}$ & 9 & 0 & 3,44 & 3,00 & 3 & 1,014 & 1,028 & 3 & 2 & 5 \\
\hline $\begin{array}{l}\text { Coerência da navegação na estrutura do } \\
\text { documento e nos elementos musicais } \\
\text { (pouco/bastante coerente) }\end{array}$ & 9 & 0 & 4,22 & 4,00 & 5 & ,833 & ,694 & 2 & 3 & 5 \\
\hline $\begin{array}{l}\text { Intuitividade dos comandos de navegação } \\
\text { (pouco/bastante intuitivo) }\end{array}$ & 9 & 0 & 3,56 & 4,00 & $4^{a}$ & 1,509 & 2,278 & 4 & 1 & 5 \\
\hline Média das questões sobre navegabilidade & 9 & 0 & 3,6667 & 3,6000 & $2,60^{\mathrm{a}}$ & 80000 & ,640 & 2,20 & 2,60 & 4,80 \\
\hline
\end{tabular}

a. Existem múltiplas modas. O menor valor é o exibido.

Questões sobre erros do usuário

\begin{tabular}{|c|c|c|c|c|c|c|c|c|c|c|}
\hline & \multicolumn{2}{|c|}{$\mathrm{N}$} & \multirow[b]{2}{*}{ Mean } & \multirow[b]{2}{*}{ Median } & \multirow[b]{2}{*}{ Mode } & \multirow[b]{2}{*}{ Std. Deviation } & \multirow[b]{2}{*}{ Variance } & \multirow[b]{2}{*}{ Range } & \multirow[b]{2}{*}{ Minimum } & \multirow[b]{2}{*}{ Maximum } \\
\hline & Valid & Missing & & & & & & & & \\
\hline $\begin{array}{l}\text { O programa se mostra tolerante aos erros } \\
\text { cometidos pelo usuário? } \\
\text { (pouco/bastante tolerante) }\end{array}$ & 9 & 0 & 4,22 & 4,00 & 5 & ,833 & ,694 & 2 & 3 & 5 \\
\hline $\begin{array}{l}\text { Facilidade de localização e correção de } \\
\text { erros (difícil/fácil de localizar) }\end{array}$ & 9 & 0 & 4,44 & 5,00 & 5 & ,882 &, 778 & 2 & 3 & 5 \\
\hline
\end{tabular}

Tabela 5.3: Tabela de frequências das respostas dos usuários

as respostas dos entrevistados e características de seu perfil. Surge, portanto, a hipótese de se, no conjunto de respostas dos usuários, há diferenças perceptíveis que possam ser relacionadas a suas características, como por exemplo a acuidade visual ou faixa etária. Na verdade, tal hipótese, considerando a acuidade visual dos participantes, é algo particularmente interessante, pois desejase comparar a experiência de uso entre estes dois grupos, considerando porém que outros dados do perfil também possam ser relevantes. Desconsiderou-se, porém, para fins de entendimento dos 


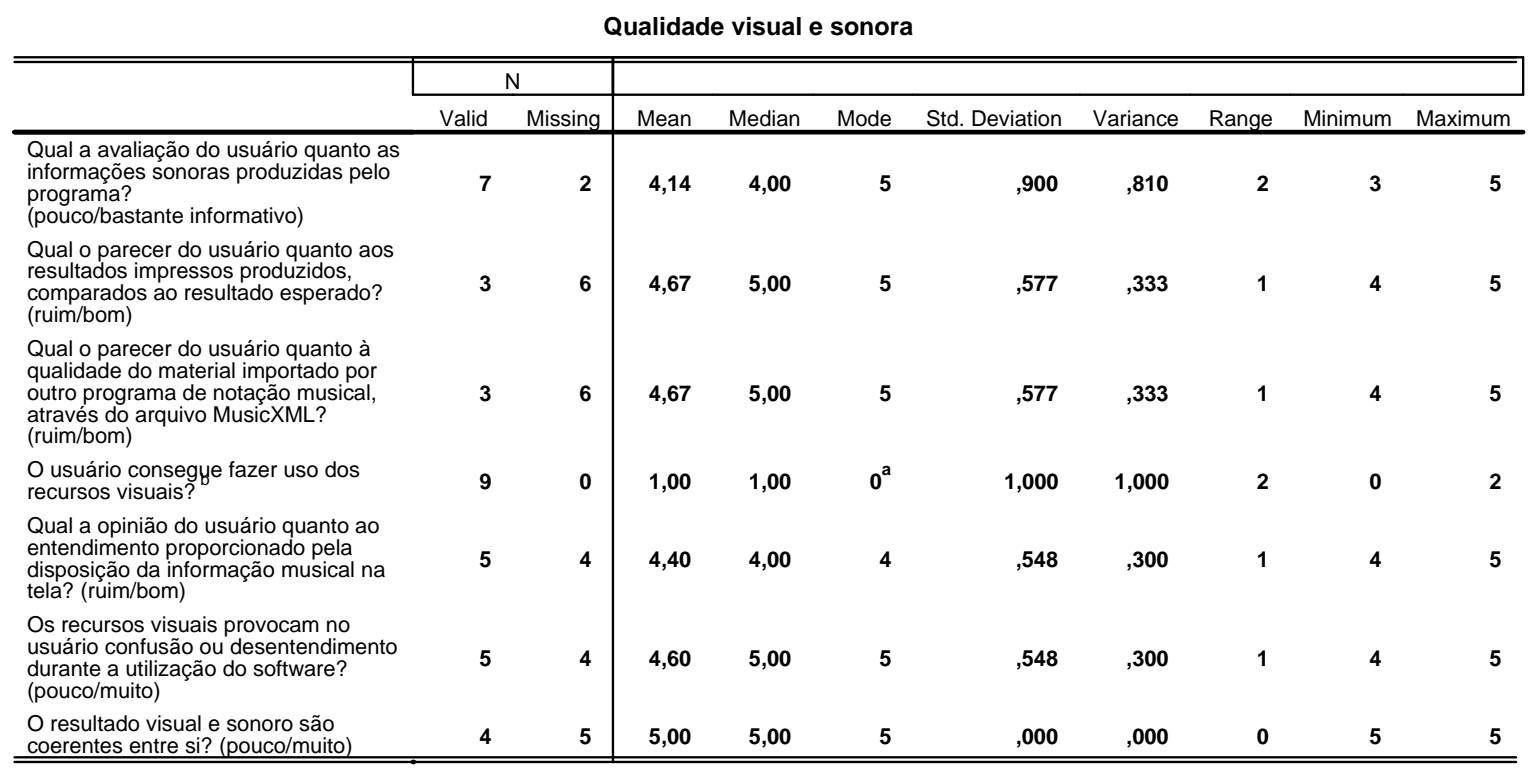

a. Existem múltiplas modas. O menor valor é o exibido.

b. 1 = não; 2 = sim, pouco; 3 = sim, bem.

\begin{tabular}{|c|c|c|c|c|c|c|c|c|c|c|}
\hline & \multicolumn{2}{|c|}{$\mathrm{N}$} & \multirow[b]{2}{*}{ Mean } & \multirow[b]{2}{*}{ Median } & \multirow[b]{2}{*}{ Mode } & \multirow[b]{2}{*}{ Std. Deviation } & \multirow[b]{2}{*}{ Variance } & \multirow[b]{2}{*}{ Range } & \multirow[b]{2}{*}{ Minimum } & \multirow[b]{2}{*}{ Maximum } \\
\hline & Valid & Missing & & & & & & & & \\
\hline $\begin{array}{l}\text { Satisfação geral no } \\
\text { uso da ferramenta }\end{array}$ & 8 & 1 & 4,75 & 5,00 & 5 & ,463 & ,214 & 1 & 4 & 5 \\
\hline $\begin{array}{l}\text { Produtividade da } \\
\text { ferramenta }\end{array}$ & 9 & 0 & 4,44 & 4,00 & 4 & ,527 & ,278 & 1 & 4 & 5 \\
\hline $\begin{array}{l}\text { Confiança nos } \\
\text { resultados }\end{array}$ & 8 & 1 & 4,13 & 4,00 & $4^{a}$ & ,835 & ,696 & 2 & 3 & 5 \\
\hline Configurabilidade & 4 & 5 & 3,50 & 3,00 & 3 & 1,000 & 1,000 & 2 & 3 & 5 \\
\hline
\end{tabular}

a. Existem múltiplas modas. O menor valor é o exibido.

b. Todas as respostas são notas livres de 1 a 5

Tabela 5.4: Tabela de frequências das respostas dos usuários

grupos, as situações óbvias de resposta como "Os recursos visuais provocam confusão ou desentendimento ao usuário?", onde por exemplo usuários cegos se abstiveram da resposta.

Todas as variáveis independentes do perfil foram portanto cruzadas com as variáveis dependentes. Foi realizado o teste do chi-quadrado de Pearson (Kirk, 2007, p. 468) e, para todas as respostas em escalas ordinais, o teste de correlação de Spearman (Kirk, 2007, p. 148). Como a acuidade visual foi dividida em apenas dois grupos (deficiente visual / visão normal), para este caso foi aplicado o Teste Exato de Fischer, mais adequado para comparações entre dois grupos distintos. Os dados onde o valor de significância era próximo de 0,05 foram reservados e compilados na tabela 5.5. Nesta tabela encontram-se os dois índices importantes para o entendimento do resultado de cada cruzamento realizado. O primeiro (correlação de Spearman) indica o quanto as duas variáveis envolvidas no cruzamento são correlatas, em um intervalo de -1 a 1 . Valores próximos de zero indicam correlação fraca; valores próximos de 1 indicam forte correlação positiva e valores próximos de -1 sugerem forte correlação negativa. O valor de significância indica a probabilidade da hipótese nula (no caso em questão, de que as variáveis cruzadas são correlatas) ser falsa. Por padrão, para estes testes assume-se um intervalo de confiança de $95 \%$, rejeitando-se a hipótese quando este valor é maior que 0,05 e aceitando-a quando o valor é menor. O intervalo de confiança, porém, é definido arbitrariamente, e por esse motivo os cruzamentos cujos valores de significância são pouco maiores que 0,05 também aparecem na tabela 5.5.

Os testes realizados não apresentaram valores de significância que sugerissem respostas diferen- 


\begin{tabular}{lrr}
\multicolumn{1}{c}{ Faixa etária dos entrevistados } & & \\
& Correl. de Spearman & Significância \\
\hline Proficiência em musicografia braille & 0,711 & 0,032 \\
Coerência da navegação na estrutura do documento e nos ele- & $-0,745$ & 0,021 \\
mentos musicais & & \\
Intuitividade dos comandos de navegação & $-0,831$ & 0,005 \\
Média das questões sobre navegabilidade & $-0,761$ & 0,017 \\
Reconhecimento dos símbolos musicais em braille & $-0,654$ & 0,056 \\
O programa se mostra tolerante aos erros cometidos pelo usuá- & $-0,859$ & 0,003 \\
rio? & &
\end{tabular}

\begin{tabular}{lrr}
\multicolumn{1}{c}{ Proficiência em informática/computaçãoo } & & \\
Questão & Correl. de Spearman & Significância \\
\hline Média das questões sobre edição & 0,634 & 0,066 \\
Facilidade de localização e correção de erros & 0,680 & 0,044 \\
Velocidade na produção musical utilizando o programa, com- & 0,992 & 0,000 \\
parando ao uso de regletes para a mesma tarefa & &
\end{tabular}

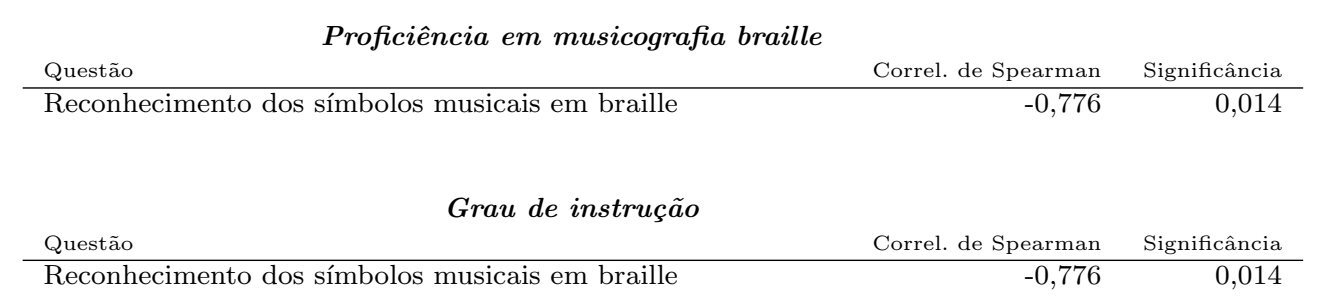

Tabela 5.5: Correlação de Spearman: Características dos usuários $\times$ respostas

tes de acordo com a acuidade visual dos entrevistados. Percebeu-se, porém, que a faixa etária dos entrevistados correlaciona-se negativamente com diversos aspectos do programa, sobretudo no que diz respeito à navegação. Proficiência em informática também foi um fator que revelou ser influente em algumas das respostas sobre edição. A nota para "Reconhecimento dos símbolos musicais em braille" mostrou-se influenciada por características do perfil, o que também pode ser observado na tabela A

\section{Resumo e análise geral das respostas}

Claramente, o modo de uso do programa é bastante diferente entre usuários deficientes visuais e com visão normal, não só pelo uso de som ou imagem, mas também pelo tempo gasto na execução de tarefas ou mesmo na navegação entre os elementos musicais. Porém, os testes realizados (sobretudo o Teste Exato de Fischer) também sugerem que, no geral, a percepção dos usuários quanto a uma série de características do programa (facilidade de uso, acessibilidade, navegabilidade, tolerância a erro, satisfação) não é divergente. Assim, embora fosse esperado que cegos e videntes demonstrassem ter experiências de uso diferentes, os testes realizados sugerem homogeneidade, indicando uma boa aproximação do conceito de desenho universal (ver seção 1.8).

Contudo, percebeu-se que a faixa etária dos entrevistados relaciona-se negativamente com certas questões (ver tabela 5.5), sugerindo que há maior facilidade e desenvoltura no uso do programa por pessoas mais jovens (que melhor avaliaram intuitividade, coerência e tolerância a erros), ao passo que indivíduos com idade mais avançada experimentaram maior dificuldade de manuseio. Este é um resultado inesperado, que poderá ser alvo de mais atenção na continuidade deste trabalho; caso esta diferença não seja mera questão de diferenças de afinidade com tecnologia, relativas às faixas etárias envolvidas, então será desejável investigar outros recursos capazes de melhorar a interação com pessoas de idade mais avançada. É importante, porém, ressaltar que as questões da tabela 5.5 que evidenciaram esta correlação negativa não foram mal avaliadas pelos usuários, sendo que a média dessas questões geralmente estão acima de 4 . 
Outra observação importante extraída da tabela 5.5 é que o quesito "Reconhecimento da musicografia braille" foi avaliado diferentemente por usuários mais experientes (com maior proficiência em musicografia braille e maior grau de instrução) e menos experientes. Os testes apontam que os mais experientes tendem a uma pior avaliação para este quesito, base na qual pode-se supor que estes usuários perceberam maiores problemas no atendimento às regras da musicografia braille, ou ainda que por serem usuários mais experientes também têm expectativas diferentes de uso do programa, nas quais regras que ainda não foram implementadas são desejáveis e importantes.

Os testes realizados também sugerem que diversos outros fatores, como o conhecimento de musicografia em tinta e o grau de conforto no uso de computadores e das grafias musicais, não são tão relevantes para a avaliação da experiência de uso.

\section{Respostas dissertativas}

O questionário aplicado (apêndice A) continha no final três perguntas dissertativas com o objetivo de saber a opinião do usuário quanto à aplicabilidade do programa, ou seja, para que fins o mesmo poderia ser utilizado. Perguntou-se também sobre o que o usuário considerava pontos positivos do programa, ou seja, possíveis artefatos que o agradaram ou colaboraram para com sua experiência de uso, e o que considerava como pontos negativos, ou seja, o que deveria ser introduzido ou melhorado no programa de forma prioritária para que fosse possível obter uma experiência de uso de maior qualidade. As respostas estão dispostas na tabela 5.6.

A primeira pergunta procura saber do usuário suas perspectivas de utilização da ferramenta. Interessante perceber como os usuários vislumbram diferentes usos do programa. Das respostas dadas, pode-se concentrar essas perspectivas de uso em três grupos principais: para fins de "composição e arranjo", "transcrições de partitura" e "interação entre alunos/professores cegos/videntes". Este último, em particular, é de grande valor para este trabalho, pois sugere fortemente que a ferramenta é capaz de atender seu propósito principal.

Questionados sobre pontos fracos do programa, os quais os usuários gostariam de vê-los resolvidos prioritariamente, verificou-se que os usuários deficientes visuais ainda desejam uma melhor comunicação sonora, solicitando recursos melhores para localização e também melhor relacionamento com outros programas para leitura de tela. Outro comentário interessante diz respeito às teclas que acionam comandos frequentes. Um dos entrevistados (com visão normal) alertou para um fato que também fora percebido pelo autor: apesar de ser aparentemente simples (e bem fácil de memorizar) que a tecla "P" (de play) seja utilizada para tocar a partitura, ela não é tão facilmente acessada pelos usuários deficientes visuais, em relação a outras teclas. De fato, percebeu-se que teclas como "Esc", "Enter", "Backspace" e as teclas de função (F1 ao F12) são acessadas mais facilmente, pois seus diferentes tamanhos, espaçamentos ou agrupamentos são facilmente sentidos pelo tato; já as teclas de letras geralmente dependem do usuário posicionar canonicamente as mãos sobre o teclado e efetuar alguns movimentos manuais de referência para a localização da tecla. Também verificou-se que muitas vezes o usuário aperta uma tecla como essa sem muita certeza de estar apertando a tecla correta, e por vezes receoso de disparar um comando errado ou que possa prejudicar sua experiência de uso.

Quanto aos pontos fortes, há uma notável frequência das respostas que elogiam a capacidade de trabalhar com polifonia, seja por uso de sinais de "em acorde" ou pela possibilidade de criar mais de um instrumento por partitura. Alguns usuários comentaram sobre o recurso de auto-diagramação como outro benefício do programa. Também é interessante notar que os usuários deficientes visuais, apesar de solicitarem melhor reatividade do programa para localização na estrutura musical, elogiaram a simplicidade com que se faz a navegação pelos elementos musicais. Também demonstraram satisfação quanto à passividade do programa, não exibindo demasiadas telas de erro ou demais 


\begin{tabular}{|c|c|c|}
\hline Questão & Usuário & Resposta \\
\hline \multirow{10}{*}{$\begin{array}{l}\text { Para quais funções ou em } \\
\text { quais situações você acredita } \\
\text { que o programa seria uma } \\
\text { ferramenta potencialmente } \\
\text { útil? }\end{array}$} & U8 & $\begin{array}{l}\text { Interação do aluno cego com professores videntes em sala de } \\
\text { aula, vale as melhorias na partitura visual na tela do pro- } \\
\text { grama. Conversão instantânea. }\end{array}$ \\
\hline & $\mathrm{U} 4 *$ & $\begin{array}{l}\text { Edição de material próprio (pode ser composição, arranjo, seja } \\
\text { o que for). Arranjo. }\end{array}$ \\
\hline & U5* & $\begin{array}{l}\text { Digitação das partituras e em aula, pro professor ditar e o } \\
\text { aluno escrever. }\end{array}$ \\
\hline & U6 & $\begin{array}{l}\text { Produção de partituras em braille, ensino da musicografia, au- } \\
\text { las de teoria / harmonia em braille }\end{array}$ \\
\hline & $\mathrm{U} 3^{* *}$ & Pra composição, principalmente. \\
\hline & U9* & $\begin{array}{l}\text { Transcrição de partituras para musicografia braille, realização } \\
\text { de aprendizado de música (não só de musicografia braille como } \\
\text { música como um todo), vai ajudar muito o professor também } \\
\text { a aprender musicografia braille, muito útil pra provas e exer- } \\
\text { cícios, materiais de apoio pra estudos, muitas utilidades. }\end{array}$ \\
\hline & U1 & Realização de transcrições \\
\hline & $\mathrm{U} 2^{*}$ & $\begin{array}{l}\text { Intercâmbio de aprendizado entre professor e alunos cegos e } \\
\text { videntes. Caso de professores cegos e alunos cegos também, } \\
\text { porque às vezes se ensina os símbolos, mas como isso vai ficar } \\
\text { na prática? }\end{array}$ \\
\hline & U7 & Pra aulas, transcrições. \\
\hline & U8 & A partitura visual \\
\hline
\end{tabular}

Segundo suas impressões, cite os principais pontos fracos do programa, que você acha que deveriam ser resolvidos ou trabalhados prioritariamente.

U4 Um pouco na parte da voz, do retorno e os sons.

U5 Ajuste com vários leitores de tela, e a parte da quarta oitava, pq ele fala hífem ao invés de oitava.

U6 Recurso de recortar e colar; importação de XML e saída direta pra impressora.

U3 Colocar um cursor intermitente, que fica mais fácil de encontrar; Embutir leitor de tela pra não ter problemas caso outro leitor não consiga ler o programa, assim fica mais confiável.

U9 Falar fórmula de compasso, um botão que lembre qual fórmula de compasso ou armadura o usuário está; falar melhor o conteúdo das caixas de diálogo; Palavras, associar sílabas com notas.

U1 Chegar mais rapidamente ao braille (à parte onde se escreve música).

U2 A questão do sinal de oitava, que não é obrigatório a cada mudança de compasso. As regras definem as ocasiões. Facilitar o acesso dos instrumentos na listagem de instrumentos. Comando "onde estou?" - não precisa dizer todas as informações, mas dizer em que janela está.

U7 Deleção de compassos inteiros / vários elementos de um compasso. As teclas "P" para tocar não são fáceis para pessoas que não vêem o teclado, escolher teclas mais próximas da posição da mão para o teclado perkins (ou enter).

U8 Escrever "em acorde", poder usar múltiplos instrumentos Segundo suas impressões, cite os principais pontos fortes do programa.
U4 Simplicidade. Poucos comandos, mas que facilitam. Facilidade de trabalhar com ele.

U5 Divisão da partitura com o começo do compasso, usando as setas pra acessar as partes.

Múltiplas pautas.

Trabalhar com mais de um instrumento ao mesmo tempo; os recursos de formatação são uma boa idéia também. É um programa diferente, ele é mais voltado pra quem já tem uma boa noção da musicografia.

U9 Fácil, acessível, inteligível, muito intuitivo, sem complicações pra formatar as coisas.

U1 Não respondeu

U2 Possibilidade de ouvir ao mesmo tempo as duas linhas que eu havia escrito, e depois ouvir separadamente.

U7 Não dá muitas telas de erros que exigem interação do usuário. Toca mais do que uma voz. Diagramação automática.

Tabela 5.6: Respostas dissertativas dos usuários. (*) usuários cegos; (**) usuários com baixa visão. 


\subsection{Testes de transcrição}

Foram realizadas transcrições de excertos musicais com a finalidade de se comparar visualmente a saída do programa em arquivo MusicXML, dados alguns exemplos de entrada em ambas as formas: tinta e braille. Os exemplos utilizados foram retirados de materiais de aula do curso de musicografia braille ministrado no Instituto Padre Chico, com a intenção de ilustrar uma possível situação real e uso do programa. Buscou-se selecionar trechos musicais onde o nível de sofisticação entre eles fosse progressivo, havendo portanto trechos simples, com poucos símbolos braille, e outros mais complexos. Foram selecionados também trechos que continham elementos que sabidamente o software, em seu estágio atual, não suportaria; esperava-se, nestes casos, comparar os resultados em busca de possíveis anomalias.

O procedimento de transcrição consistia simplesmente em tentar reproduzir os elementos musicais contidos no original em braille dentro do ambiente Delius. Feito isso, extraiu-se as versões MusicXML das partituras, que foram abertas e impressas pelo programa de código aberto MuseScore. Buscou-se introduzir os símbolos de forma fiel ao original. As partituras originais e as transcrições realizadas estão disponíveis no apêndice C.

O primeiro teste ( C.1) foi feito sobre a primeira série do Pozzoli, um exercício rítmico frequentemente utilizado em aulas de teoria musical para iniciantes. No caso em questão, a transcrição de notas e pausas foi correta, bem como a notação da fórmula de compasso e barras duplas de compasso. Durante a trancrição, percebeu-se que o software reproduzia corretamente o ritmo. Na impressão do arquivo MusicXML notou-se que o sentido das hastes musicais e a distribuição dos compassos na partitura eram decididos pelo programa. De fato, esse é o procedimento usual para quando o arquivo XML não contém explicitamente tais regras de leiaute, e tal recurso foge do escopo do Delius. No entanto, efetuar a correção no programa de destino é um processo bastante simples. É possível crer que praticamente todas as partituras convertidas necessitarão de pequenos ajustes manuais, embora espere-se que estes ajustes sejam tão somente para melhorias no domínio visual; as versões transcritas presentes no apêndice não passaram por nenhum tipo de ajuste de leiaute $^{1}$. No momento do teste o programa não contemplava recursos para a inserção das instruções textuais contidas na versão original em braille. Este recurso seria de grande importância, pois é comum que partituras em braille contenham orientações sobre como proceder com possíveis indicações características da obra em questão.

O segundo teste também é um exercício rítmico, a décima sétima série do Pozzoli. Notas e pausas e fórmula de compasso foram transcritos corretamente. Este teste, porém, exige o reconhecimento de alguns símbolos musicais a mais, como a ligadura de prolongamento e nota duplamente pontuada. Para este teste, o resultado final verificado no MuseScore apontou uma barra de compasso fora da posição esperada (na penúltima seção). Também não foram enumeradas as seções, porém os compassos; embora haja configuração no programa para exibir ou ocultar a indicação de número de compasso no início da linha, não é possível determinar que essa numeração não corresponde aos compassos mas sim a grupos deles. Também nota-se por este teste (e o anterior) que exercício é exibido em pentagrama, enquanto que o original em tinta é representado sem linhas. Estes recursos visuais específicos também fogem do escopo deste programa na versão atual. Na oitava seção há uma tercina, símbolo ainda não suportado pelo Delius; foram inseridas semicolcheias no lugar que, apesar de produzirem um resultado incorreto e extrapolarem o limite de duração do compasso, foram exibidas e tocadas pelo programa.

Os testes 3 e 4 são oriundos da mesma partitura original, nomeada como "Canção de cinco notas". Este é um exercício simples para solfejo, utilizando apenas as notas de dó a sol e pouco

\footnotetext{
${ }^{1}$ A marcação "Nylon-str Gt" que aparece no primeiro teste refere-se ao instrumento escolhido arbitrariamente, no Delius, para o pentagrama em questão. No MuseScore esta marca poderia ser facilmente removida ou modificada.
} 
desafio rítmico. Neste caso, novos elementos musicais aparecem: anotação de andamento (Allegro), ligaduras de expressão, sinais de dinâmica $(p, m p, f)$ e sinais de repetição. O excerto original em braille desta peça possui três versões diferentes, onde estes sinais são acrescentados gradualmente. Os testes 3 e 4 se referem, portanto, às versões 1 e 3 . No teste 3 não há repetições, sendo a primeira parte (compassos 1 ao 8) reescrita praticamente na íntegra após o compasso 16. Nesta versão também não há ligaduras de expressão nem dinâmicas. O teste 4 trouxe corretamente as indicações de dinâmica e as ligaduras, porém não produziu bons resultados na indicação de repetição (o texto $D$. C. ao Fim não foi reproduzido no arquivo MusicXML).

O teste 5 refere-se à peça popular "Tico tico no fubá". Esta partitura possui células rítmicas mais requintadas, com diversas síncopas e acidentes, além de vários sinais de repetição, mudanças de armadura de clave e acordes cifrados. A mudança de tonalidade do compasso 22 foi realizada, sendo possível perceber a alteração durante o uso do Delius, mas a versão MusicXML não exibiu essa indicação corretamente. Indicações de casa 1 e 2 (compassos 20 e 21) ainda não eram compreendidas pelo programa no momento da transcrição, idem para os acordes cifrados. O sinal segno foi escrito corretamente mas posicionado erroneamente no compasso 20 (deveria ser colocado sobre o compasso 5). A versão original em braille não ultrapassa o compasso 23 , de modo que o restante da peça não pôde ser transcrito. Esta transcrição apontou uma série de divergências entre as versões originais em braille e tinta:

- No compasso 5, as notas lá (ligadas) foram escritas na versão braille como ré2

- No compasso 6, a segunda e terceira nota sol foram escritas como ré; entre elas havia ligadura de prolongamento (que liga somente notas de mesma altura) que não pôde produzir a representação esperada.

- No compasso 7, encontrou-se uma nota si (:⿱:⿴囗⿱一一) $)$ escrita em braille como dó ( $: \mathbf{:})$.

- No compasso 10, outra nota lá foi escrita como si. Neste caso, a próxima nota da sequência (dó) seguiu a regra de oitavas do braille e acabou posicionando todas as notas restantes do compasso em uma oitava abaixo. O erro não se propagou para mais notas por conta de um sinal de oitava no início do compasso $11(\vdots:)$.

- No compasso 12 , uma nota si (:: $)$ aparecia, no original em braille, no lugar de sol sustenido (::). Com isso, o segundo sol sustenido deste compasso acabou perdendo também o valor da alteração, sendo realizado como sol natural.

- No compasso 14, a penúltima nota divergia entre sol, na versão em braille, e ré na versão em tinta.

- No compasso 17, a segunda nota divergia entre sol, na versão em braille, e lá na versão em tinta.

\footnotetext{
${ }^{2} \mathrm{O}$ autor observou que este erro é comum em transcrições, provavelmente por conta da simetria dos símbolos,no

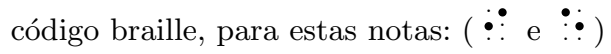




\section{Capítulo 6}

\section{Conclusão}

O presente trabalho tratou do desenvolvimento de um aplicativo para notação musical cujo método de entrada principal é o braille, detalhando todas as etapas deste processo, passando pela discussão sobre seus propósitos, escolhas de tecnologias, métodos de implementação e a submissão do mesmo à experiência prática de uso por voluntários.

O projeto foi desenvolvido dentro da filosofia de software livre, pois entende-se que prover acessibilidade não se faz apenas com adaptação sensorial; é necessário garantir igualdade de uso e de acesso a recursos também pelos fatores sociais e econômicos - e neste ponto, as tecnologias assistivas ainda têm muito no que melhorar. Além do mais, espera-se que o interesse no projeto não esteja limitado ao autor ou ao presente trabalho, e que possa ser acolhido pela comunidade de desenvolvedores de software livre, estando aberto a colaboradores que acreditem na validade da proposta e demonstrem interesse em envolver-se no projeto. Atualmente o projeto está hospedado no repositório do SourceForge no endereço http://www.sourceforge.com/projects/delius, havendo neste endereço os pacotes de instalação, o código-fonte, manuais e um sistema de rastreamento de erros, aberto para que qualquer pessoa possa relatar problemas encontrados e ser avisado quando correções forem efetuadas.

Inicialmente, procurou-se fazer um levantamento de quais tecnologias estavam disponíveis para esta finalidade, avaliando seu custo, suporte, vantagens e desvantagens. Percebeu-se que haviam poucos softwares no mercado para este propósito e também que seus usuários esperam ferramentas melhores e com mais funções.

Esta pesquisa buscou então fazer um mapeamento da musicografia braille, comparando-a com a musicografia tradicional em tinta e buscando entender modelos computacionais que permitissem a conversão entre estas linguagens. Neste processo, verificou-se que certos símbolos podem ser transcritos por mera transliteração, enquanto que outros dependem de heurísticas mais complexas. Também foi possível identificar pontos críticos deste processo de conversão, que necessitam de uma análise mais profunda, e espera-se que em futuras versões do programa tais pontos sejam resolvidos.

Durante a etapa de desenvolvimento do programa, muitos problemas foram enfrentados na tentativa de se controlar minimamente a relação do software com os leitores de tela. A princípio, o desenvolvimento foi realizado em Java por conta de uma série de vantagens, como a ampla possibilidade de utilização de componentes externos também sob licenças de software livre, a perspectiva de cativar desenvolvedores interessados em envolver-se no projeto, além da facilidade em conceber um produto multiplataforma. Contudo, acabou-se por perceber que a acessibilidade em Java é um assunto particularmente delicado, principalmente quando se refere ao componente Swing, a interface gráfica utilizada na versão corrente.

As análises do capítulo 5 mostram a etapa atual de desenvolvimento do programa, de acordo 
com as experiências e os depoimentos dos usuários entrevistados. Analisando o resumo das frequências das respostas e seus histogramas percebe-se que, de forma geral, o usuário demonstra já na etapa atual alguma satisfação no uso do programa.

Os testes de transcrição realizados nos fornecem um panorama do atual estágio de desenvolvimento do programa, permitindo-nos comparar resultados impressos e imaginar uma situação real de conversão no uso em sala de aula.

A partir da análise exploratória dos dados colhidos usando a escala psicométrica de Likert, percebe-se que os usuários mostram-se satisfeitos com o atendimento às regras da musicografia braille, porém usuários mais experientes tendem demonstrar menor satisfação; através de relatos feitos diretamente ao autor pelos entrevistados, acredita-se que essa satifação acima da média, sobretudo no caso dos usuários mais avançados, indica que o programa atende às regras da musicografia braille pelo menos ao nível dos softwares BME e Musibraille (ver seção 1.6), mas que a necessidade prática de uso, para estas pessoas, ainda exige maior cobertura para que se alcance as reais expectativas dos usuários.

A análise das respostas dissertativas dos entrevistados sugere que há uma orientação positiva do Delius em direção ao seu objetivo principal; é possível vislumbrar que, havendo continuidade do trabalho, principalmente en se agregando desenvolvedores voluntários interessados na causa, em um futuro próximo o programa pode ser útil para alunos cegos atualmente sofrem com os hiatos de comunicação e na troca de conhecimentos, visto que frequentam um ambiente de ensino de música normalmente populado, em sua grande maioria, por pessoas videntes, que geralmente não têm conhecimento das especificidades da musicografia braille.

As respostas dissertativas também nos oferecem uma boa noção das expectativas dos usuários com relação ao programa. Com base nelas foi possível mapear as próximas implementações e melhorias que deverão ser feitas.

\subsection{Necessidades imediatas e passos futuros}

\section{Necessidades imediatas}

Certamente muitas melhorias ainda devem ser feitas ao programa. Com base nas respostas dissertativas dos usuários e pela percepção do autor ao observá-los usando o programa pela primeira vez, foram elencados os seguintes tópicos como prioritários para as próximas jornadas de desenvolvimento do Delius, seja pelo autor ou por quaisquer pessoas que desejem envolver-se no projeto.

- Tela de configuração de nova partitura. Na versão atual, a criação da partitura se dá por etapas; insere-se uma nova partitura no documento, escolhe-se um instrumento inicial, configurase o instrumento, navega-se ao ponto de entrada e então o usuário pode começar a escrever música. Seria desejado que em uma única tela o usuário pudesse parametrizar uma nova partitura em sua totalidade, configurando instrumentos usados, definindo fórmulas de compasso e armadura de claves, podendo ainda persistir estas configurações e reutilizando-as posteriormente pela seleção em uma lista de "Modelos". Este procedimento é comum em softwares de notação musical como o MuseScore e o Sibelius, facilitando bastante o processo inicial, sobretudo para usuários deficientes visuais onde a navegação é mais lenta.

- Alteração da interface gráfica, de Swing para SWT. Espera-se com isso facilitar a comunicabilidade do programa com leitores de tela, uma vez que o SWT relaciona-se com o sistema operacional em um nível mais baixo que o Swing ou AWT. Há, porém, a necessidade de se 
fazer uma série de estudos iniciais; em primeiro lugar porque o SWT mostrou-se bastante complicado para o desenvolvimento de componentes personalizados acessíveis; em segundo lugar, porque isso demandaria um pacote de instalação mais sofisticado, que pudesse levar em consideração as dependências de bibliotecas do SWT, que são diferentes a cada plataforma ou sistema operacional.

- Acrescentar mais (e diferentes) recursos para localização do usuário dentro das estruturas do documento. Entende-se que cada usuário, além de meras preferências, também tem maneiras diferentes de entender a partitura em diversos aspectos. É desejável que o programa seja, neste aspecto, tão diversificado quanto as capacidades dos usuários do programa.

- Prover recursos para trabalhar com cifras musicais e música vocal, dando possibilidade de inserção de textos combinados com linhas melódicas. Acredita-se que estes recursos atendam uma parcela bastante significativa das necessidades dos usuários.

- Melhorar o recurso de partitura gráfica simultânea. Talvez seja desejável criar um componente mais apropriado, que permita não só melhor diagramação como também mais interação com os símbolos equivalentes em braille.

- Importação e exportação de arquivos do tipo BMML.

\section{Outros recursos desejáveis}

Também deseja-se acrescentar os seguintes recursos:

- Atalho rápido para conversão de partituras para MusicXML com abertura do arquivo por um outro programa definido por configuração; este recurso facilitaria a comparação do resultado gráfico final com a versão em braille.

- Definição de uma interface que permita futuramente a conexão com possíveis repositórios de documentos musicais.

- Outro ponto a ser abordado é permitir que o aplicativo sirva como um assistente de aprendizado da musicografia braille. Uma das possibilidades é fazer com que o programa forneça ao usuário excertos musicais que deverão ser codificados pelo mesmo em braille; o programa analisaria a resposta do usuário, informando-lhe de possíveis erros.

- Uma das ampliações desejadas seria fazer com que o aplicativo permitisse a produção de conteúdo musical mesclado ao conteúdo literário, auxiliando também na produção de material didático musical com trechos textuais explicativos, entre outras possibilidades. Além do mais, material em braille costuma conter o que é chamado de Notas de Transcrição (SEE/ME, 2002), já que muitas vezes se faz necessário a adição de esclarecimentos ou orientações adicionais quando certos símbolos possuem significados não convencionados no braille.

- Poderia ser interessante possibilitar que o usuário separasse as partituras da tela principal, jogando-as para outras janelas e possivelmente para um segundo monitor. Isso não só melhoraria a customização do ambiente como também poderia ser mais confortável para quando duas pessoas estejam utilizando o programa simultaneamente (professores e alunos, por exemplo).

\subsection{Considerações finais}

Infelizmente, boa parte das experiências vividas durante este trabalho não cabem no texto desta dissertação. A experiência da imersão em um assunto que nos obriga ao pensamento transcender 
os limites impostos pelos sentidos traz inevitavelmente um repensar sobre muitos aspectos antes tidos como axiomáticos para o que se entende por viver e por conviver. Também não pode ser aqui expressado corretamente a sensação gratificante de ter tido a oportunidade de compreender um pouco melhor estas relações humanas tão complexas. É também confuso dar-se conta que fazer valer a igualdade entre as pessoas incide diretamente em lidar com suas diferenças.

Mais do que isso, vale mencionar o tamanho real da problemática da inclusão, não apenas na questão da deficiência visual. A quantidade de fatores envolvidos apenas no escopo deste deste trabalho, entendendo-o como algo bastante específico dentro dos contextos da inclusão e da acessibilidade, nos permite ter uma noção da quantidade de desafios ainda merecedores de atenção. Parte do problema do presente trabalho se resolve com música; outras partes com números, com tecnologias, com psicologias, com leis, com dinheiro e com muitos outros recursos, mas sobretudo - e imperativamente - com bom-senso. E é pela certeza de que as necessidades e os desafios deste problema exigem amplas interações multidisciplinares que aqui se clama para que as iniciativas acadêmicas, públicas, privadas e outras sejam mais participativas, e não bastando, para que se lute contra o monopólio de conhecimentos relativos às tecnologias assistivas; a dignidade e o direito de igualdade não são objetos que podem receber um código de barras e um espaço numa prateleira. 
Apêndice A

Questionário aplicado 


\section{Avaliação Delius}

*Obrigatório

\section{Dados pessoais}

Nome *

Idade *

É deficiente visual? *

- Sim

- Não

Se sim, qual?

Grau de instrução *

- Sem instrução

- Fundamental completo

- Ensino médio completo

- Superior completo

- Pós-graduação

Proficiência em informática/computação *

Como você se considera, com relação aos seus conhecimentos relacionados ao uso de computadores?

- Usuário básico (navega na internet, utiliza processadores de texto)

- Usuário intermediário (instala programas, faz back-ups, configura e customiza seu ambiente)

- Usuário avançado (roda ou gerencia serviços, sabe programar, repara defeitos)

Indique na escala o quanto sente-se confortável em utilizar o computador em seu dia-a-dia *

$\begin{array}{lllll}1 & 2 & 3 & 4 & 5\end{array}$

Pouco confortável @ @ Bastante confortável

Proficiência em musicografia braille *

Como você se considera, com relação aos seus conhecimentos em musicografia braille?

- Nenhum conhecimento

Pouco conhecimento (sabe símbolos básicos)

- Conhecimento médio (é capaz de transcrever um ditado)

- Usuário avançado (ministra aulas, domina formalidades)

Indique na escala o quanto sente-se confortável em utilizar a musicografia braille em seu dia-a-dia *

$\begin{array}{lllll}1 & 2 & 3 & 4 & 5\end{array}$

Pouco confortável ๑ @ Bastante confortável 
Proficiência em musicografia tradicional *

Como você se considera, com relação aos seus conhecimentos em musicografia tradicional?

- Nenhum conhecimento

Pouco conhecimento (sabe símbolos básicos)

Conhecimento médio (é capaz de transcrever um ditado)

Usuário avançado (ministra aulas, domina formalidades)

Indique na escala o quanto sente-se confortável em utilizar a musicografia tradicional (em tinta) no dia-a-dia *

$\begin{array}{lllll}1 & 2 & 3 & 4 & 5\end{array}$

Pouco confortável $\odot \odot \odot$ Bastante confortável

Quais sistemas operacionais você utiliza em seu(s) computador(es) ?*

$\square$ Windows

$\square$ Linux

$\square$ Mac

$\square$ Outros

$\square$ Não sabe

\section{Leitores de tela utilizados pelo usuário}

Caso utilize programas leitores de tela, por favor indique-os abaixo.
$\square$ JAWS
NVDA
Virtual Vision
$\square$ Orca
VoiceOver
Outros

Utiliza softwares para escrever música?

Tanto para notação em braille com para notação tradicional

o Sim

○ Não

Caso utilize, escreve o nome destes softwares abaixo.

Escreva tanto os que recebem entrada em braille (MusiBraille, BME) quanto programas para produzir partituras gráficas (Finale, Sibelius, Encore). 


\section{Avaliação Delius}

\section{B. Materiais utilizados para o experimento}

Data e hora do experimento

Local do experimento

Dados da CPU

Quantidade de memória

Sistema Operacional

Versão do aplicativo

Tempo de experiência prévia do usuário com o aplicativo

\section{Dados das tarefas efetuadas}

\section{Tarefa 0}

Instalação do aplicativo mediante um roteiro de instruções

a. Execute o instalador do aplicativo e siga suas instruções

b. Abra o aplicativo

Tempo gasto

em minutos

Teve que recomeçar o experimento?

o Sim

○ Não 
Grau de dificuldade da tarefa segundo a opinião do usuário

$\begin{array}{lllll}1 & 2 & 3 & 4 & 5\end{array}$

Fácil $\odot \odot \odot \odot ~ ○$ Difícil

Grau de sucesso obtido

Segundo a opinião do usuário

$\begin{array}{lllll}1 & 2 & 3 & 4 & 5\end{array}$

Insatisfatório $\odot \odot \odot$ Satisfatório

Localizar informação musical específica em um arquivo e fazer a devida correção, mediante um gabarito impresso (em braille ou tinta, à escolha do usuário).

a. Abra o documento intitulado "tarefa1.delius"

b. Ouça o conteúdo da partitura contida no documento

c. Leia o trecho musical no gabarito

d. Encontre um ou mais erros e efetue a devida correção

Tempo gasto

em minutos

Erros encontrados

\section{Teve que recomeçar o experimento?}

o Sim

- Não

Grau de dificuldade da tarefa

segundo a opinião do usuário

$\begin{array}{lllll}1 & 2 & 3 & 4 & 5\end{array}$

Fácil $\odot \odot \bigcirc \bigcirc$ Difícil

Grau de sucesso obtido

Segundo a opinião do usuário

$\begin{array}{llllll}1 & 2 & 3 & 4 & 5\end{array}$

Insatisfatório ๑ ๑ $\odot$ Satisfatório

Tarefa 2

Dada uma linha melódica simples, procure livremente enriquecê-la utilizando os instrumentos e as paralelas fornecidas no arquivo

a. Abra o arquivo "tarefa2.delius"

b. Ouça e navegue nos elementos criados.

c. Utilize o segundo e o terceiro instrumento para criar um arranjo para a melodia do primeiro instrumento

d. Utilize vozes, acordes, sinais de "em acorde", conforme sua vontade.

e. Salve o arquivo ao final, com outro nome. 
Tempo gasto

em minutos

Erros encontrados

Teve que recomeçar o experimento?

- Sim

○ Não

Grau de dificuldade da tarefa

segundo a opinião do usuário

$\begin{array}{lllll}1 & 2 & 3 & 4 & 5\end{array}$

Fácil $\odot \odot \odot$ Difícil

Grau de sucesso obtido

Segundo a opinião do usuário

$\begin{array}{lllll}1 & 2 & 3 & 4 & 5\end{array}$

Insatisfatório $\odot \odot \odot$ Satisfatório 


\section{Avaliação Delius}

\section{Resultados da aplicação do experimento}

\section{D1. Navegação}

Velocidade de aprendizado/entendimento dos comandos de navegação

De acordo com a opinião do usuário, que item na escala é mais apropriado para descrever a velocidade do processo de aprender a navegar pelos elementos musicais

$\begin{array}{lllll}1 & 2 & 3 & 4 & 5\end{array}$

Lento $\odot \odot$ Rápido

Frequência com que o usuário se perde durante a navegação

Qual item da escala é mais apropriado para descrever a frequência com que o usuário perde a noção de sua localização dentro do documento/partitura?

$$
\begin{array}{lllll}
1 & 2 & 3 & 4 & 5
\end{array}
$$

Raramente $\odot \odot \odot \odot$ Frequentemente

\section{Velocidade com que o usuário alcança posições desejadas}

Na intenção do usuário alcançar um determinado elemento musical da partitura, como ele opinaria sobre a velocidade com que ele é capaz de fazer isso, pela escala abaixo?

$$
\begin{array}{lllll}
1 & 2 & 3 & 4 & 5
\end{array}
$$

Lentamente $\odot \odot$ Rapidamente

Coerência da navegação na estrutura do documento e nos elementos musicais

Qual o julgamento que o usuário faz quanto à coerência da organização das estruturas musicais, durante a navegação em uma partitura?

$$
\begin{array}{lllll}
1 & 2 & 3 & 4 & 5
\end{array}
$$

Pouco coerente $\bigcirc \bigcirc \bigcirc$ Bastante coerente

Intuitividade dos comandos de navegação

Após experimentar a navegação pela partitura musical, o usuário achou a forma de fazer isso intuitiva? Responda de acordo com a escala abaixo.

$$
\begin{array}{lllll}
1 & 2 & 3 & 4 & 5
\end{array}
$$

Pouco intuitivo $\bigcirc \bigcirc \bigcirc$ Bastante intuitivo

\section{D2. Edição}

Inserção e remoção de elementos musicais, produção musical

Facilidade com que se insere ou modifica conteúdo musical na partitura

Qual a opinião do usuário quanto a dificuldade/facilidade de se inserir símbolos musicais na partitura?

$$
\begin{array}{lllll}
1 & 2 & 3 & 4 & 5
\end{array}
$$

Difícil $\odot \odot \odot$ Fácil

Velocidade na produção musical utilizando o programa, comparando ao uso de regletes para a mesma tarefa

$$
\begin{array}{lllll}
1 & 2 & 3 & 4 & 5
\end{array}
$$


Lenta $\odot \odot \odot \odot$ Rápida

Velocidade na produção musical utilizando o programa, comparando ao uso de máquina braille, para a mesma tarefa

$1 \quad 2 \quad 3 \quad 4 \quad 5$

Lenta $\odot \odot \odot \odot$ Rápida

Reconhecimento dos símbolos musicais em braille

Na opinião do usuário, quanto o programa reconhece os símbolos musicais de acordo com as regras de musicografia braille

$\begin{array}{llllll}1 & 2 & 3 & 4 & 5\end{array}$

Reconhece pouco $\odot \odot \odot \odot$ Reconhece bem

Confiança com relação ao resultado musical produzido utilizando o programa

Qual a opinião do usuário quanto à confiabilidade que pode ser dada a uma partitura musical produzida utilizando o programa

$$
\begin{array}{lllll}
1 & 2 & 3 & 4 & 5
\end{array}
$$

Pouca confiança $\odot \odot \odot$ Muita confiança

\section{D3. Controle de erros}

O programa se mostra tolerante aos erros cometidos pelo usuário?

Entende-se por pouco tolerante o programa que, ao receber do usuário comandos inválidos ou não esperados, impede que o mesmo continue operando-o de forma consistente

$$
\begin{array}{lllll}
1 & 2 & 3 & 4 & 5
\end{array}
$$

Pouco tolerante $\odot \odot$ Bastante tolerante

\section{Facilidade de localização e correção de erros}

Em caso de notas ou outros elementos musicais escritos equivocadamente, o usuário os localiza com qual grau de dificuldade/facilidade?

$$
\begin{array}{lllll}
1 & 2 & 3 & 4 & 5
\end{array}
$$

Difícil de localizar $\odot \odot$ Fácil de localizar

\section{D4. Produção sonora}

Qual a avaliação do usuário quanto as informações sonoras produzidas pelo programa?

Quanto ao resultado sonoro produzido pelo leitor de tela, enquanto o usuário navega ou produz música dentro do ambiente do programa.

$$
\begin{array}{llllll}
1 & 2 & 3 & 4 & 5
\end{array}
$$

Pouco informativo $\odot \odot \odot$ Bastante informativo

\section{D5. Saídas}

Qual o parecer do usuário quanto aos resultados impressos produzidos, comparados ao resultado esperado? $\begin{array}{lllll}1 & 2 & 3 & 4 & 5\end{array}$

Ruim $\odot \odot \bigcirc$ Bom 
Qual o parecer do usuário quanto à qualidade do material importado por outro programa de notação musical, através do arquivo MusicXML?

$\begin{array}{lllll}1 & 2 & 3 & 4 & 5\end{array}$

Ruim $\odot \bigcirc \bigcirc$ Bom

\section{D6. Experiências visuais}

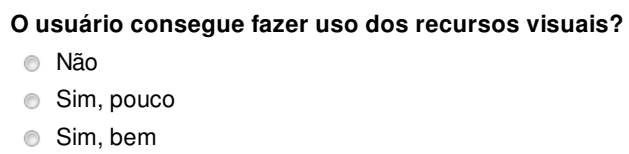

Necessita de configuração específica de baixa visão?

Não

Sim

Qual a opinião do usuário quanto ao entendimento proporcionado pela disposição da informação musical na tela?

$\begin{array}{lllll}1 & 2 & 3 & 4 & 5\end{array}$

Ruim $\odot \odot \odot$ Bom

Os recursos visuais provocam no usuário confusão ou desentendimento durante a utilização do software? $\begin{array}{lllll}1 & 2 & 3 & 4 & 5\end{array}$

Pouco $\odot \odot \odot$ Muito

O resultado visual e sonoro são coerentes entre si?

Responder caso o usuário faça uso dos recursos visuais e de leitura de tela simultaneamente $\begin{array}{lllll}1 & 2 & 3 & 4 & 5\end{array}$

Pouco $\odot \odot \odot$ Muito

\section{D7. Aspectos gerais}

Baseado na experiência geral obtida com o aplicativo, pensando especificamente em sua etapa atual de desenvolvimento, dê uma nota de 1 a 5 quanto aos seguintes aspectos:

Satisfação geral no uso da ferramenta

$\begin{array}{lllll}1 & 2 & 3 & 4 & 5\end{array}$

00000

Produtividade da ferramenta

$\begin{array}{lllll}1 & 2 & 3 & 4 & 5\end{array}$

- 000

Confiança nos resultados

$\begin{array}{lllll}1 & 2 & 3 & 4 & 5\end{array}$

$\circ \circ 000$

Configurabilidade 
O quanto o programa se permite modificado para ajustar-se ao usuário

$\begin{array}{lllll}1 & 2 & 3 & 4 & 5\end{array}$

(-) $\odot \circ \odot$

Para quais funções ou em quais situações você acredita que o programa possa ser uma ferramenta potencialmente útil?

Segundo suas impressões, cite os principais pontos fracos do programa, que você acha que deveriam ser resolvidos ou trabalhados prioritariamente

Segundo suas impressões, cite os principais pontos fortes do programa 


\section{Apêndice B}

\section{Histogramas das respostas dos usuarios}

B.1 Perfil dos entrevistados
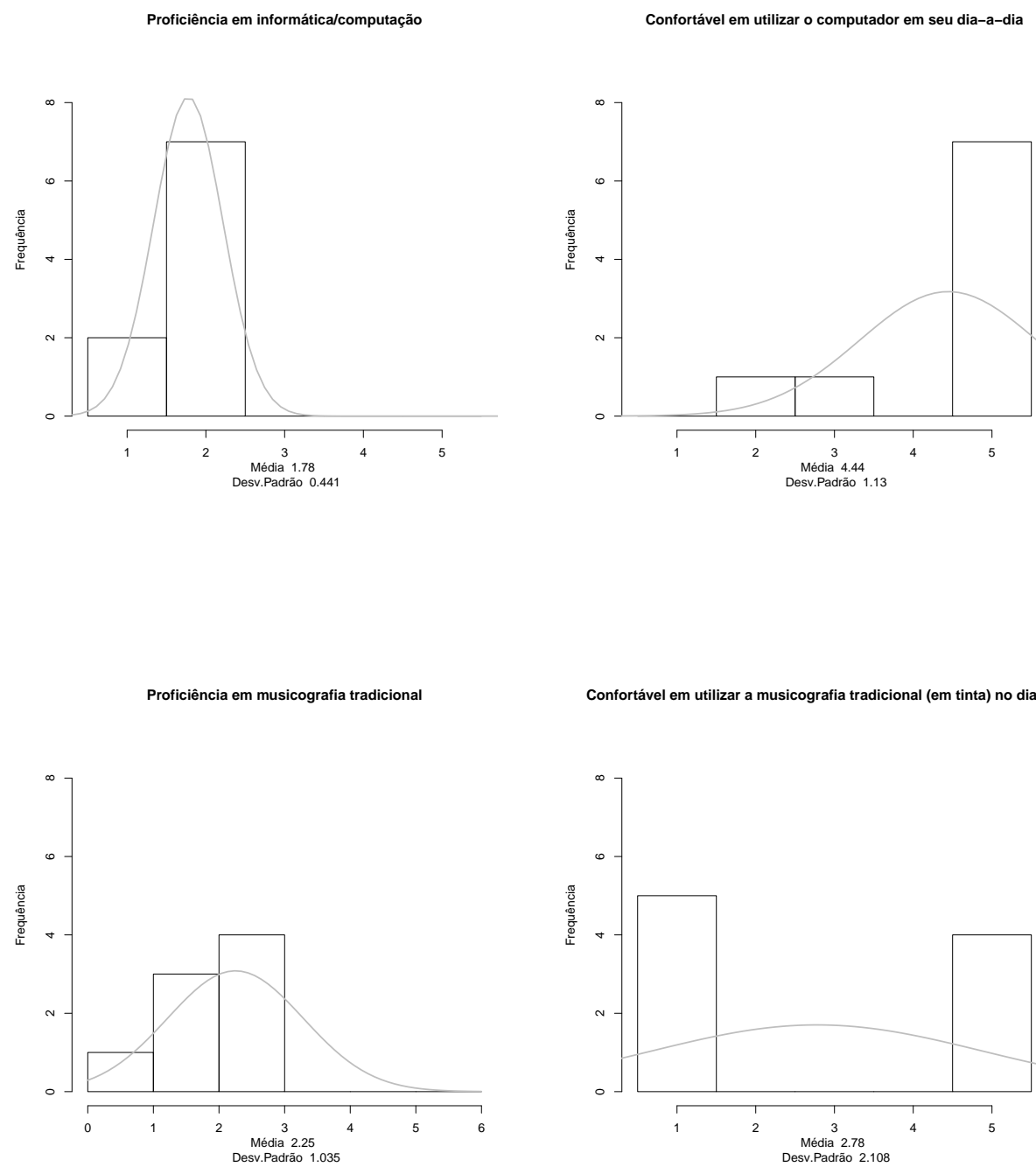

Confortável em utilizar a musicografia tradicional (em tinta) no dia-a-dia

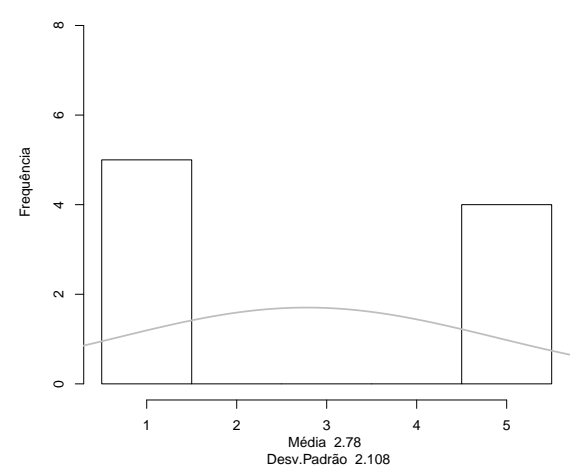



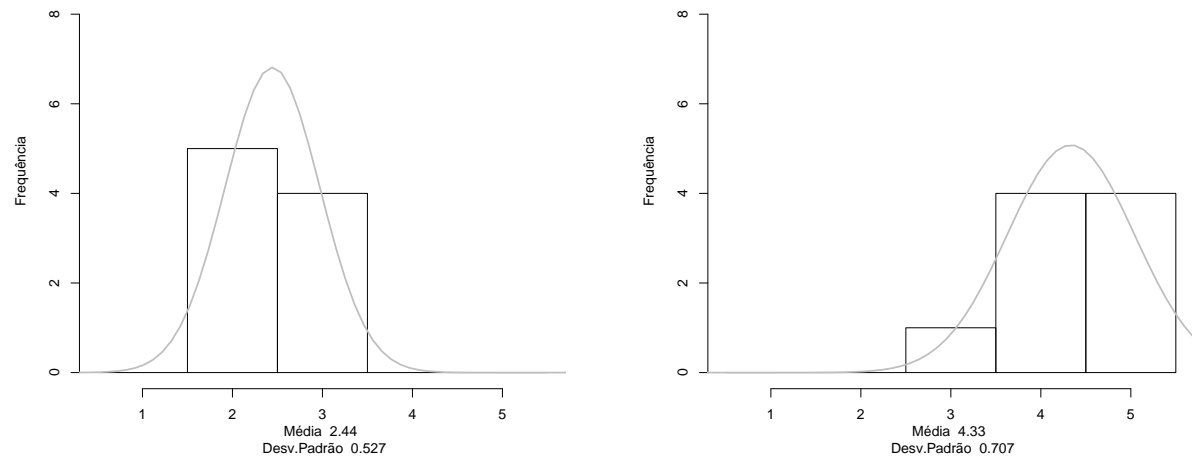

\section{B.2 Tarefas realizadas}

Tarefa 1

T1 - Tempo gasto

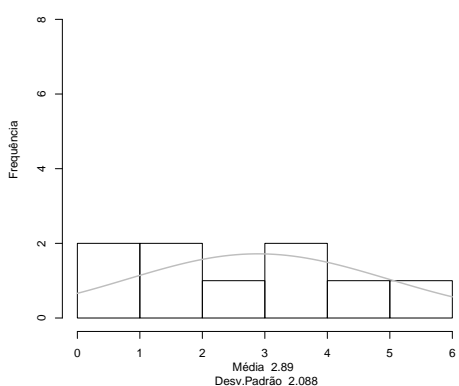

Tarefa 2
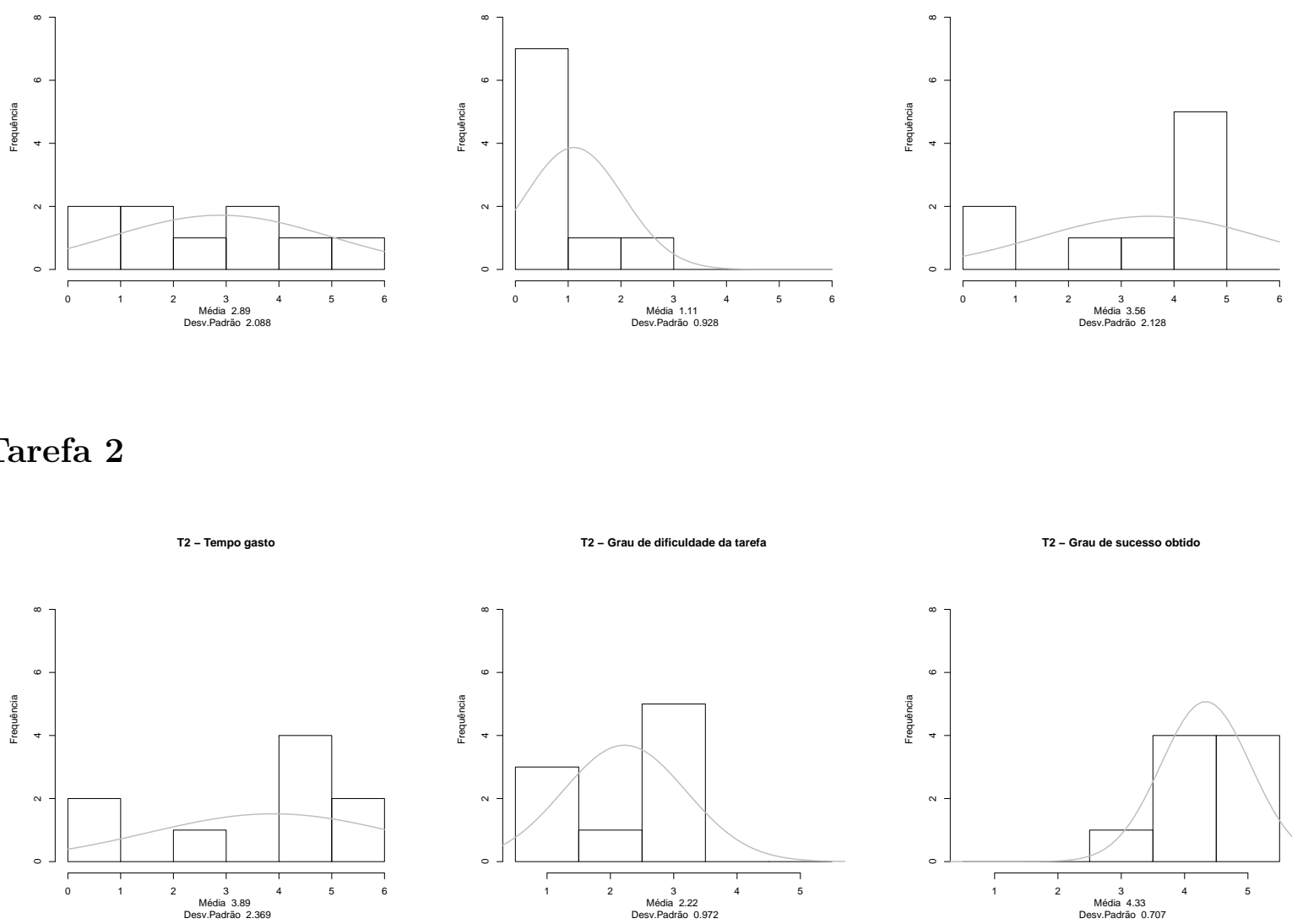

T2 - Grau de sucesso obtido

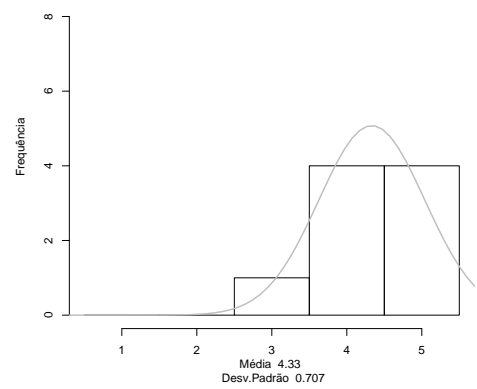

\section{B.3 Questões sobre navegação}



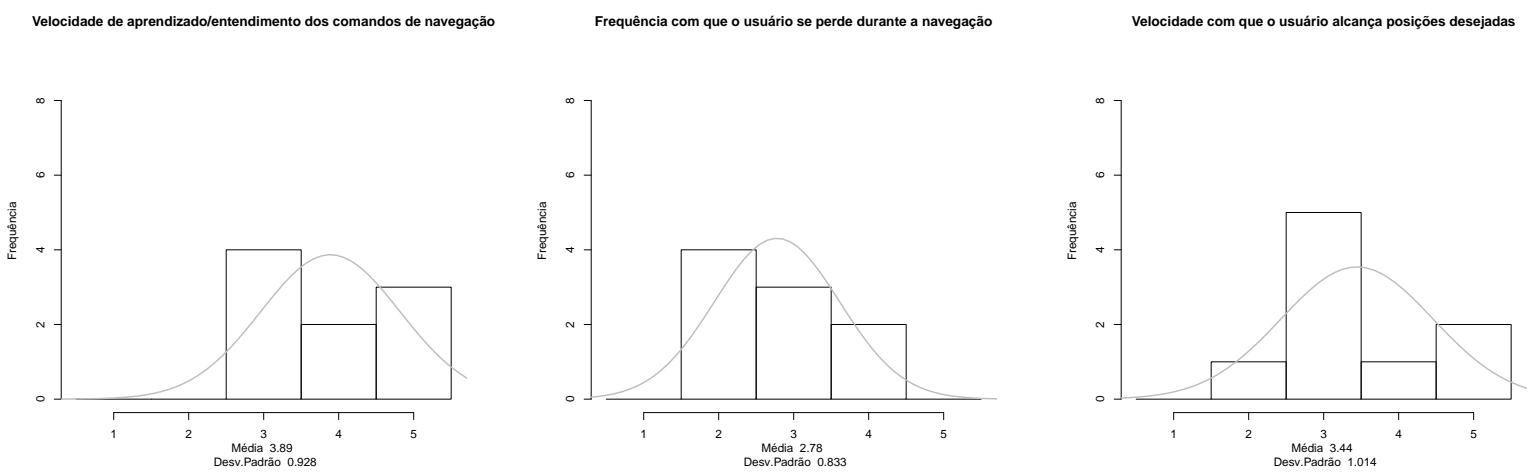

Coerência da navegação na estrutura do doc. e nos el. musicais

Intuitividade dos comandos de navegação
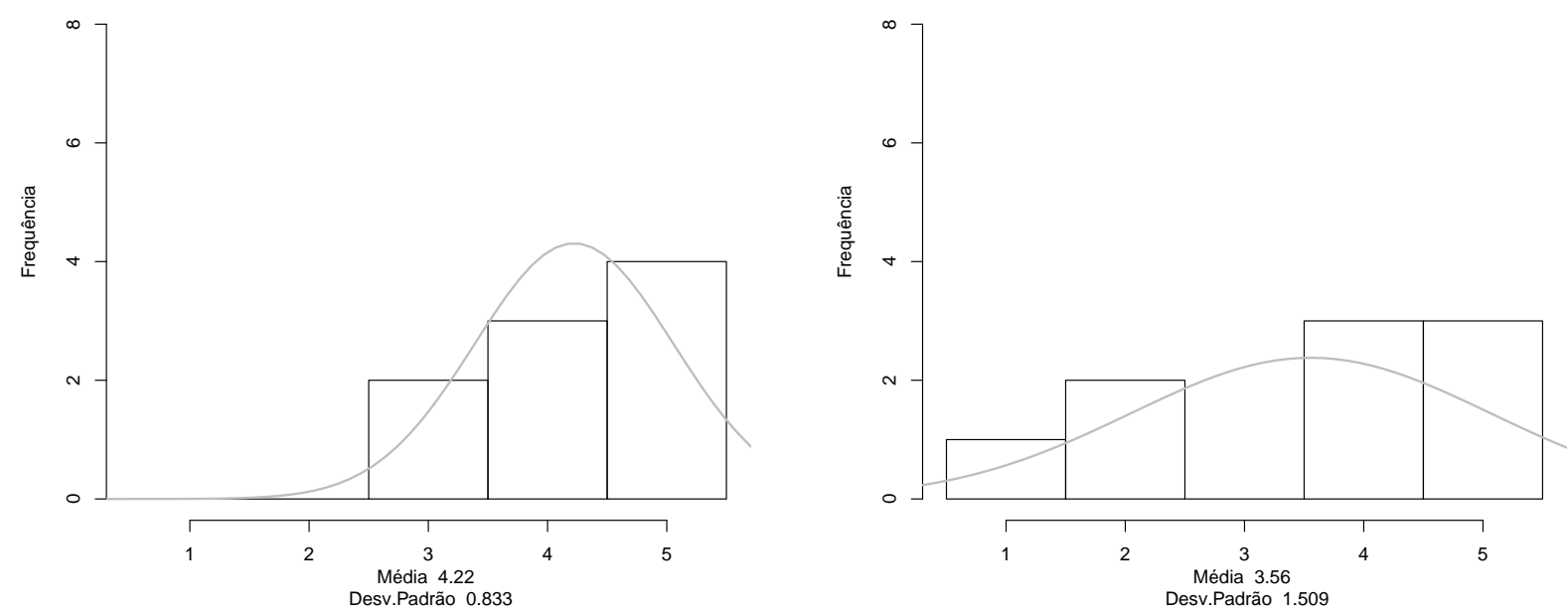

B.4 Questões sobre edição

Facilidade com que se insere conteúdo musical na partitura

Velocidade comparando ao uso de regletes
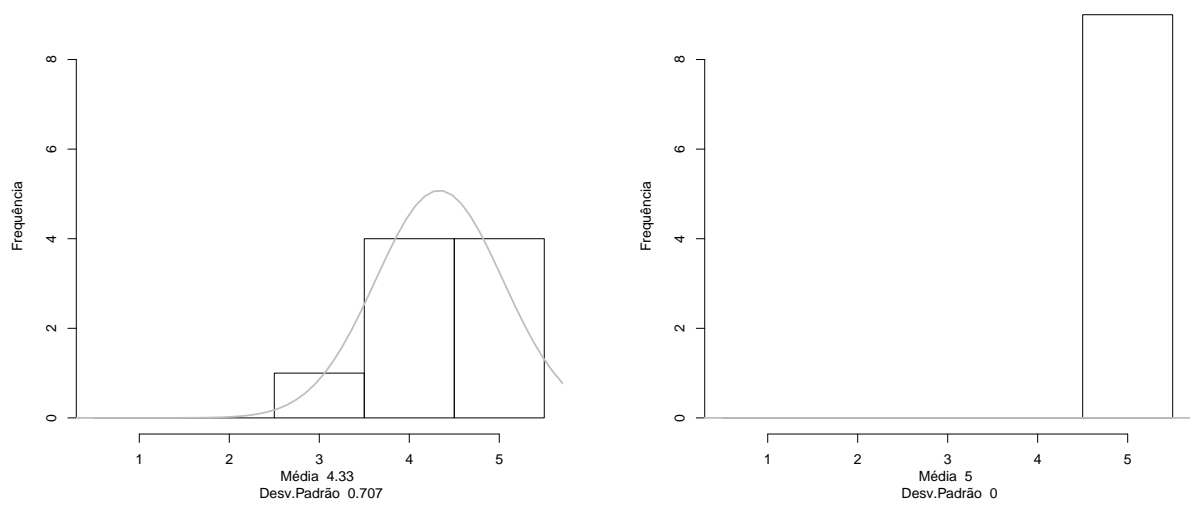
Velocidade comparando ao uso de máquina braille

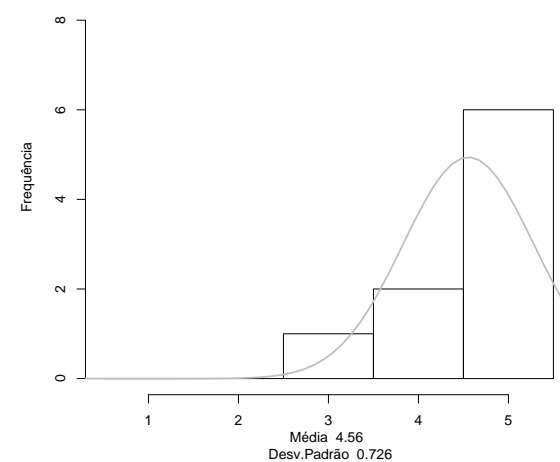

Reconhecimento dos simbolos musicais em braille

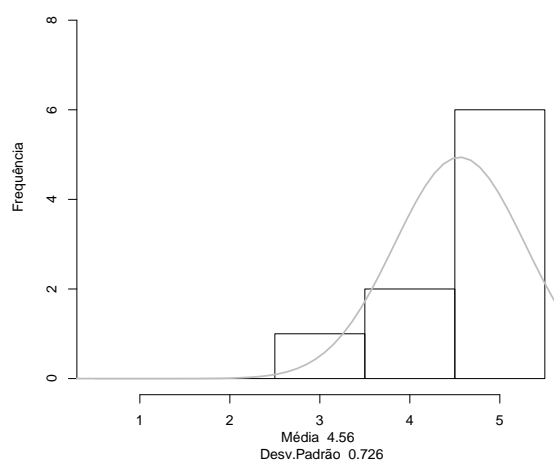

Confiança com relação ao resultado musical produzido

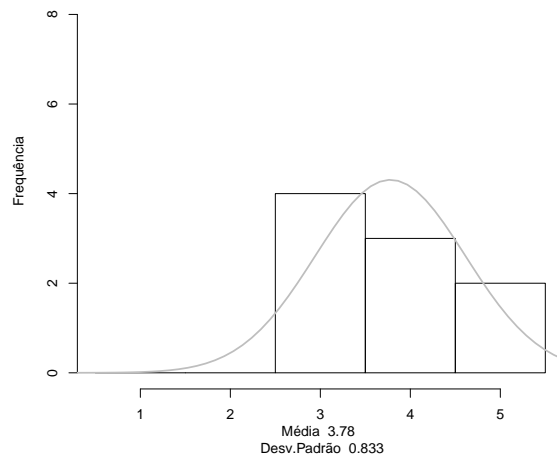

\section{B.5 Qualidade visual e sonora}
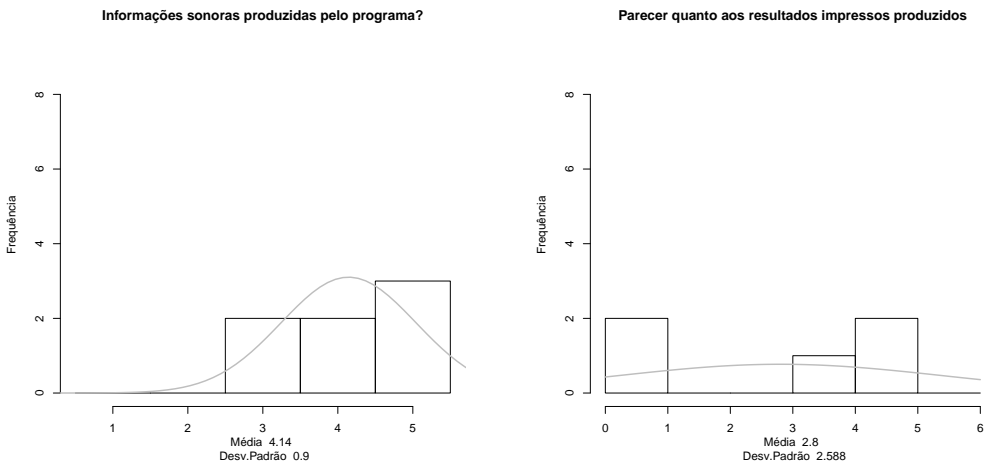

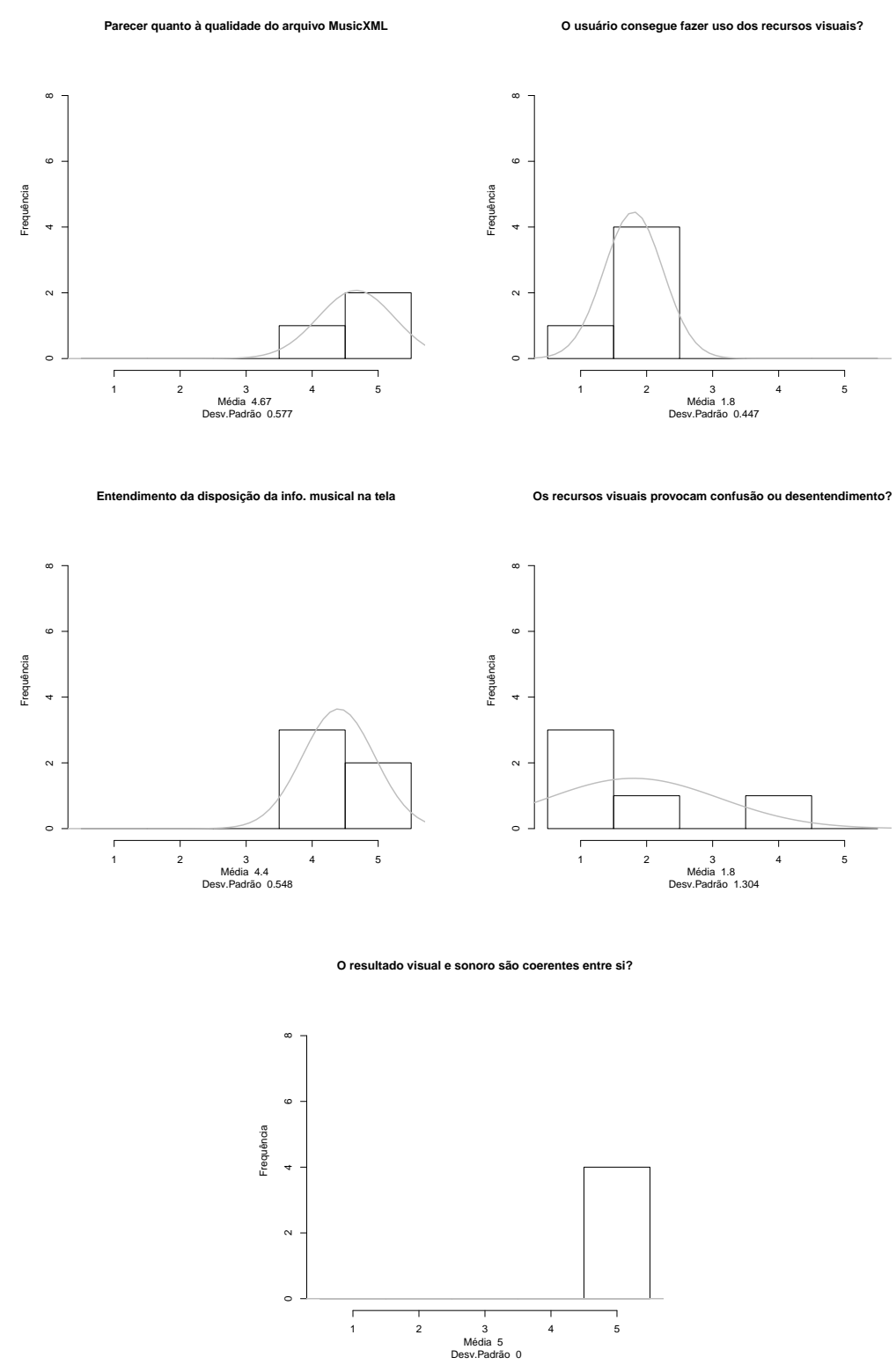

B.6 Questões sobre erros do usuário

O programa se mostra tolerante aos erros cometidos pelo usuário?

Facilidade de localização e correção de erros
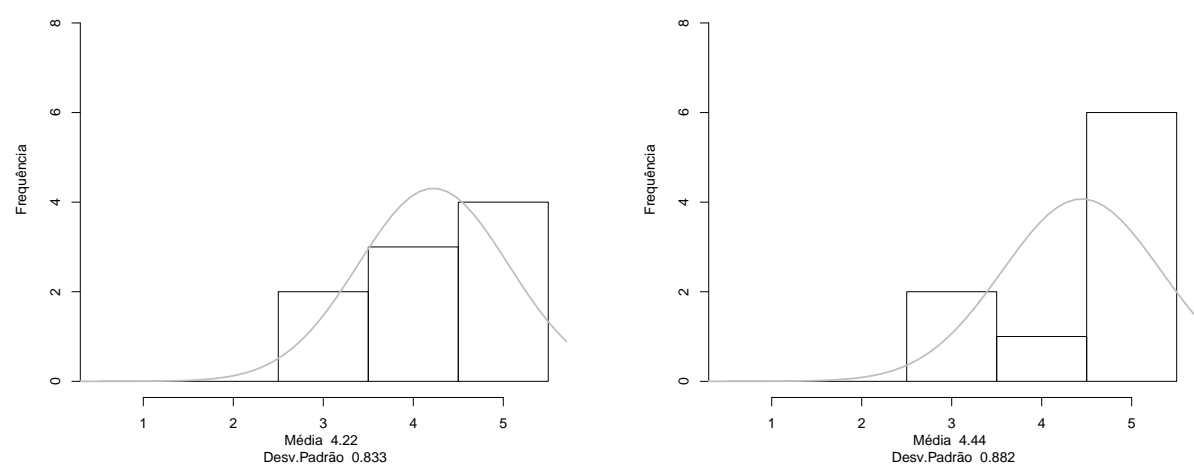
B.7 Avaliações gerais da experiência de uso da ferramenta

Satisfação geral no uso da ferramenta

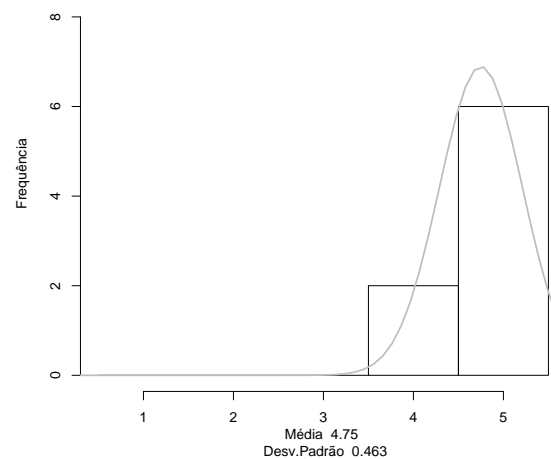

Confiança nos resultados

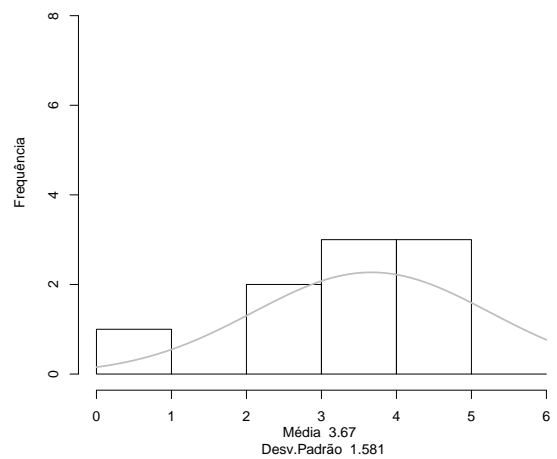

Produtividade da ferramenta

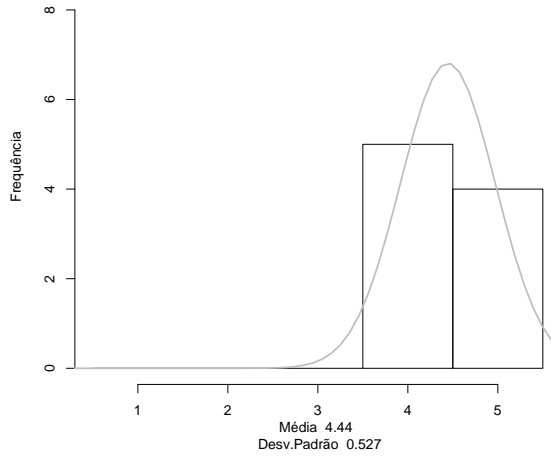

Configurabilidade

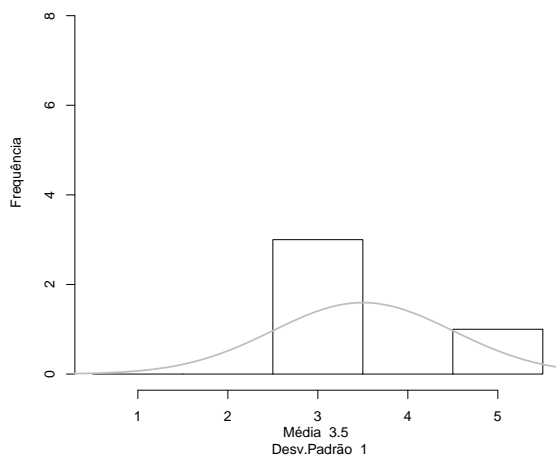


Apêndice $C$

Testes de transcrição realizados 


\section{C.1 Teste 1}

Original em braille

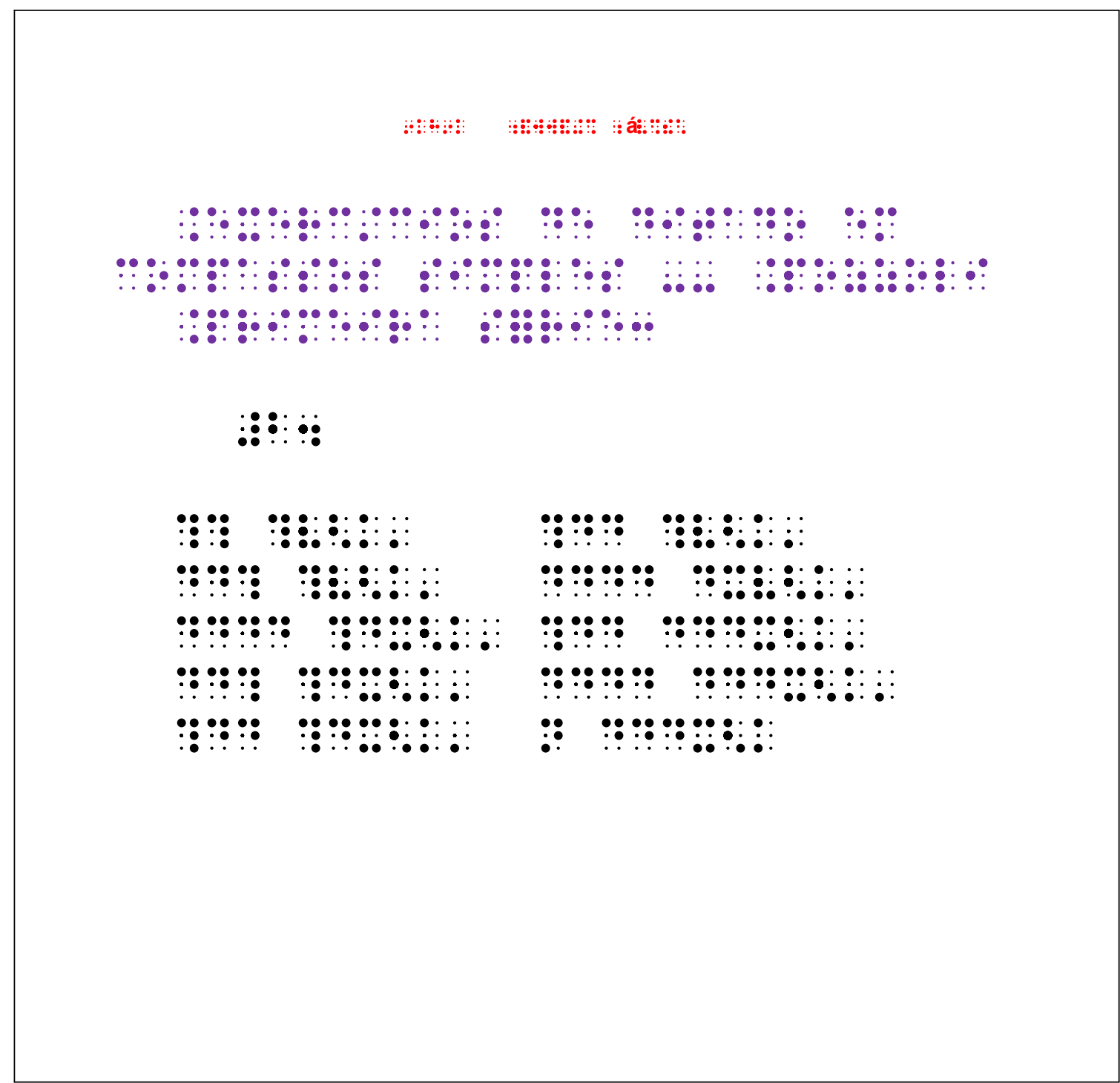

Original em tinta

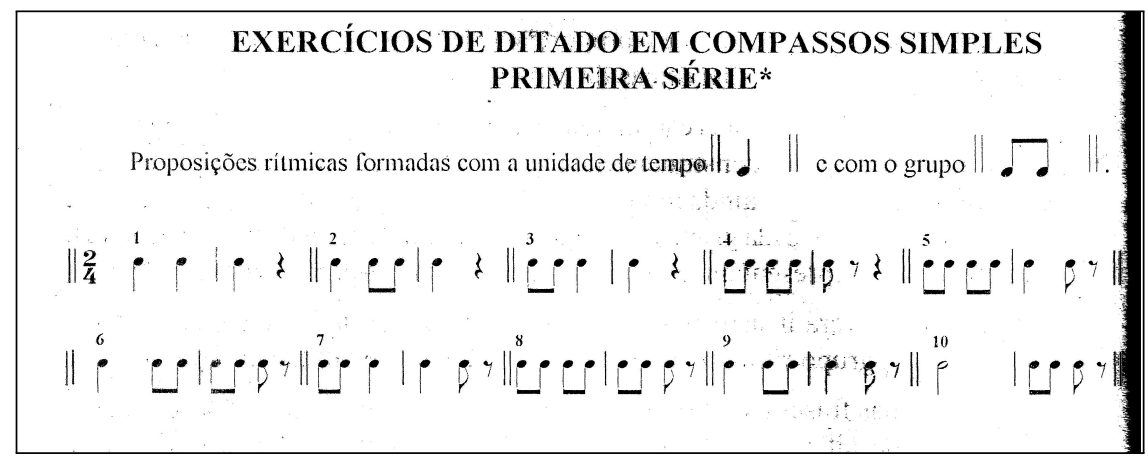


Versão produzida pelo Delius

\section{Teste 1 Pozzoli pg 26}

Nylon-str.Gt Nylon-str.Gt

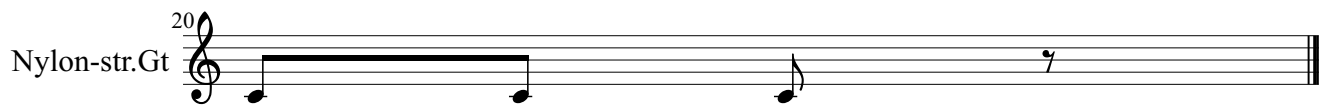




\section{C.2 Teste 2}

Original em braille

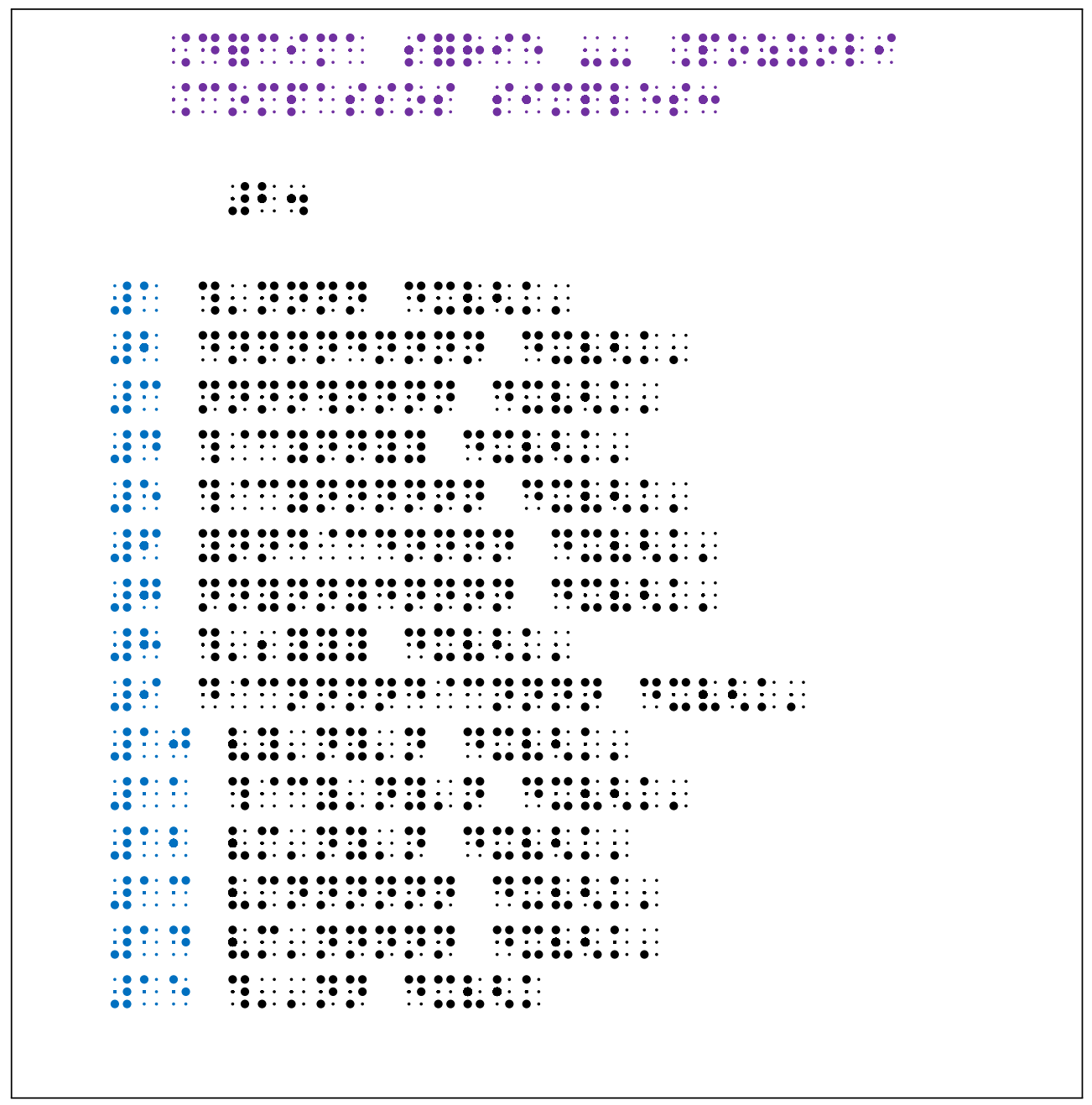

Original em tinta

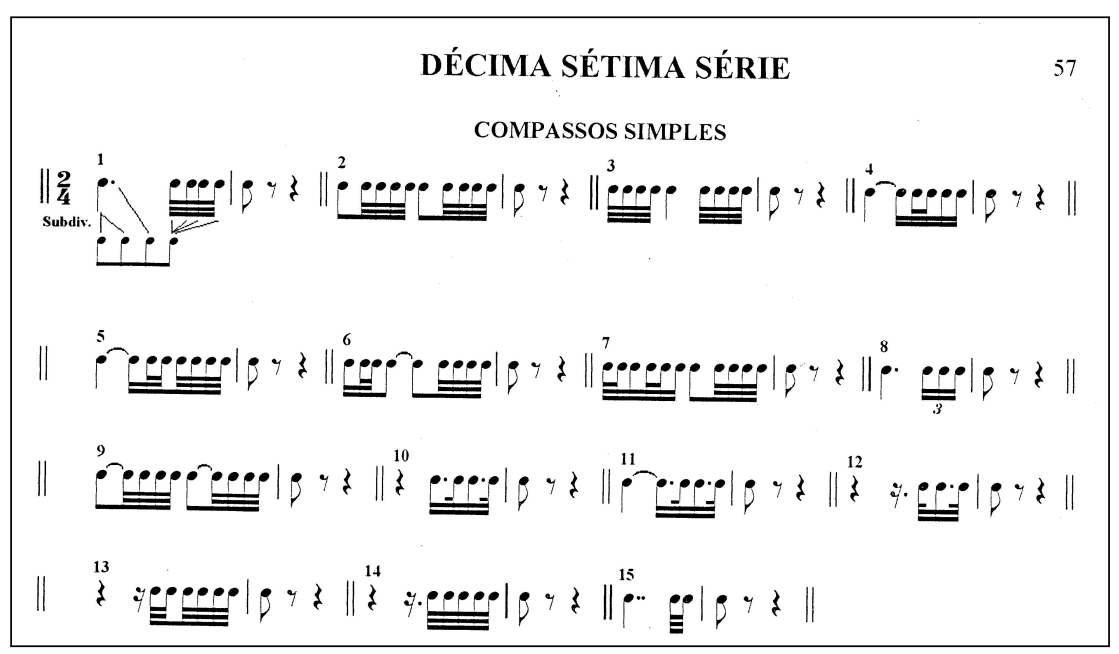


Versão produzida pelo Delius

\section{Teste 2 - Decima Setima Serie}

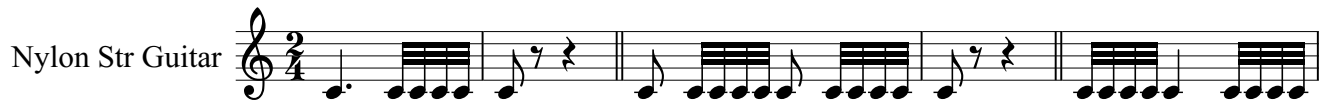
Nylon Str Guitar (2) Nylon Str Guitar Nylon Str Guitar (2)

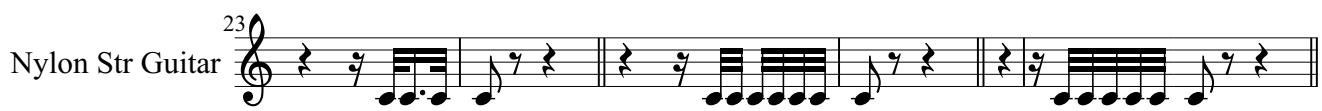
Nylon Str Guitar 
108 APÊNDICE C

\section{C.3 Teste 3}

Original em braille

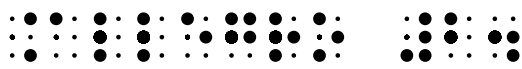

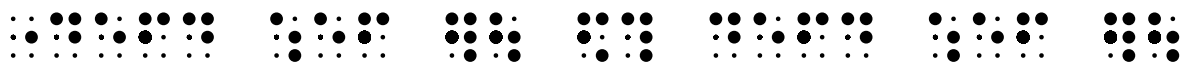

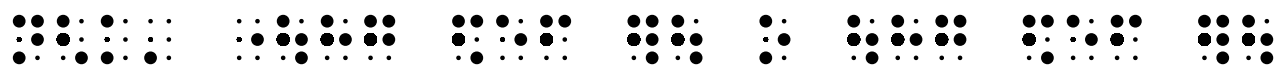

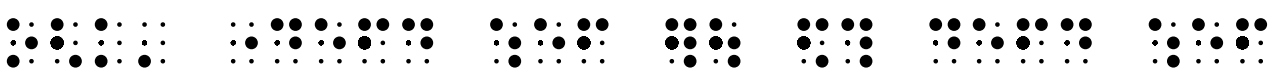

$$
\begin{aligned}
& \because: \because: \because: \because: \vdots:
\end{aligned}
$$

Original em tinta

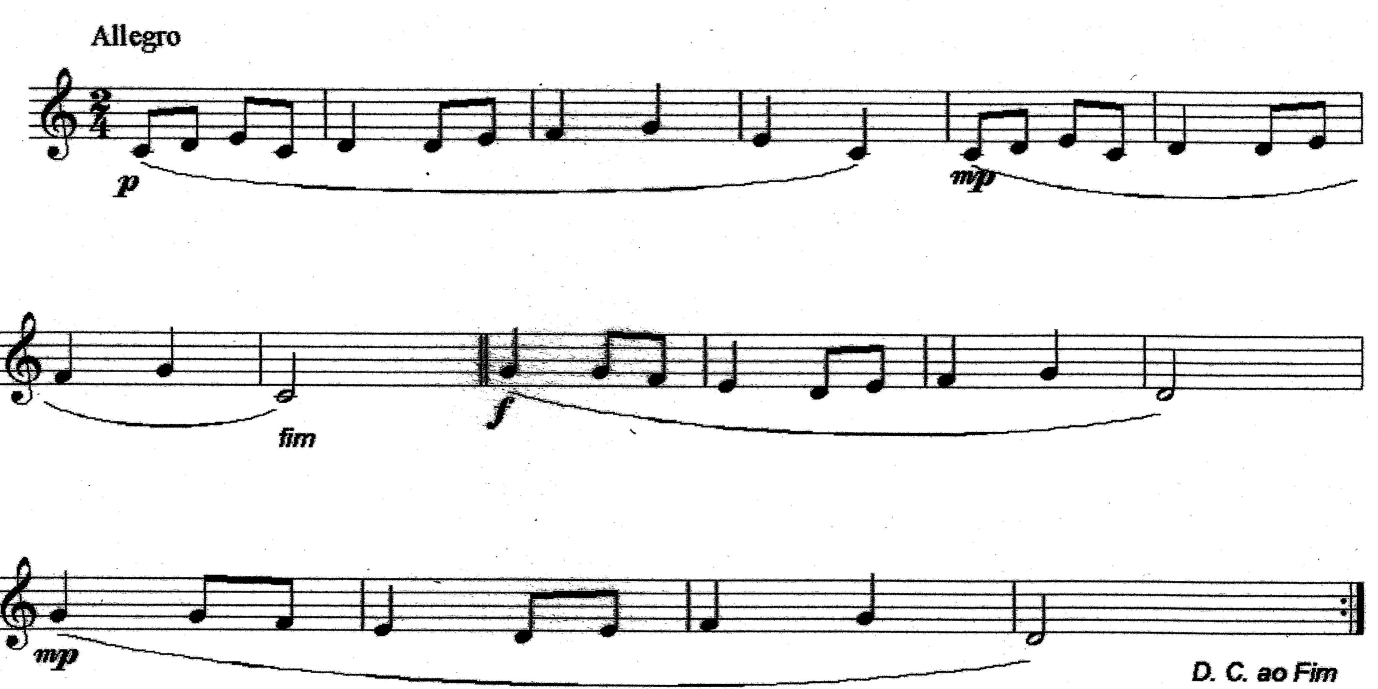


Versão produzida pelo Delius

\section{Teste 3 - Cancao de cinco notas}

Nylon Str Guitar

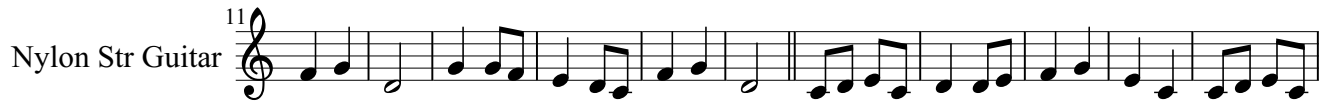
Nylon Str Guitar 
110 APÊNDICE C

\section{C.4 Teste 4}

Original em braille

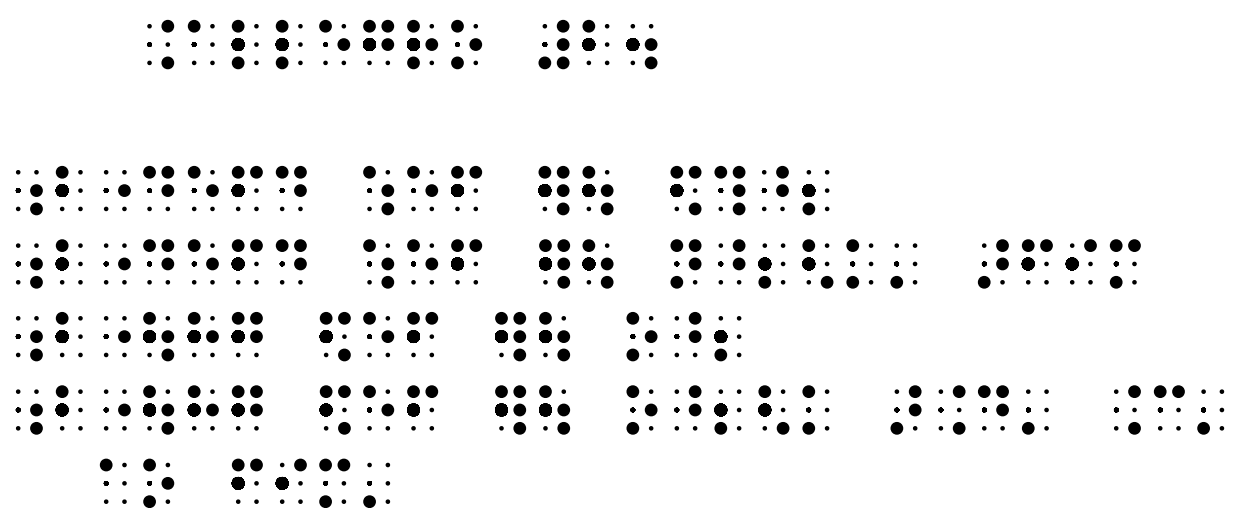

Original em tinta
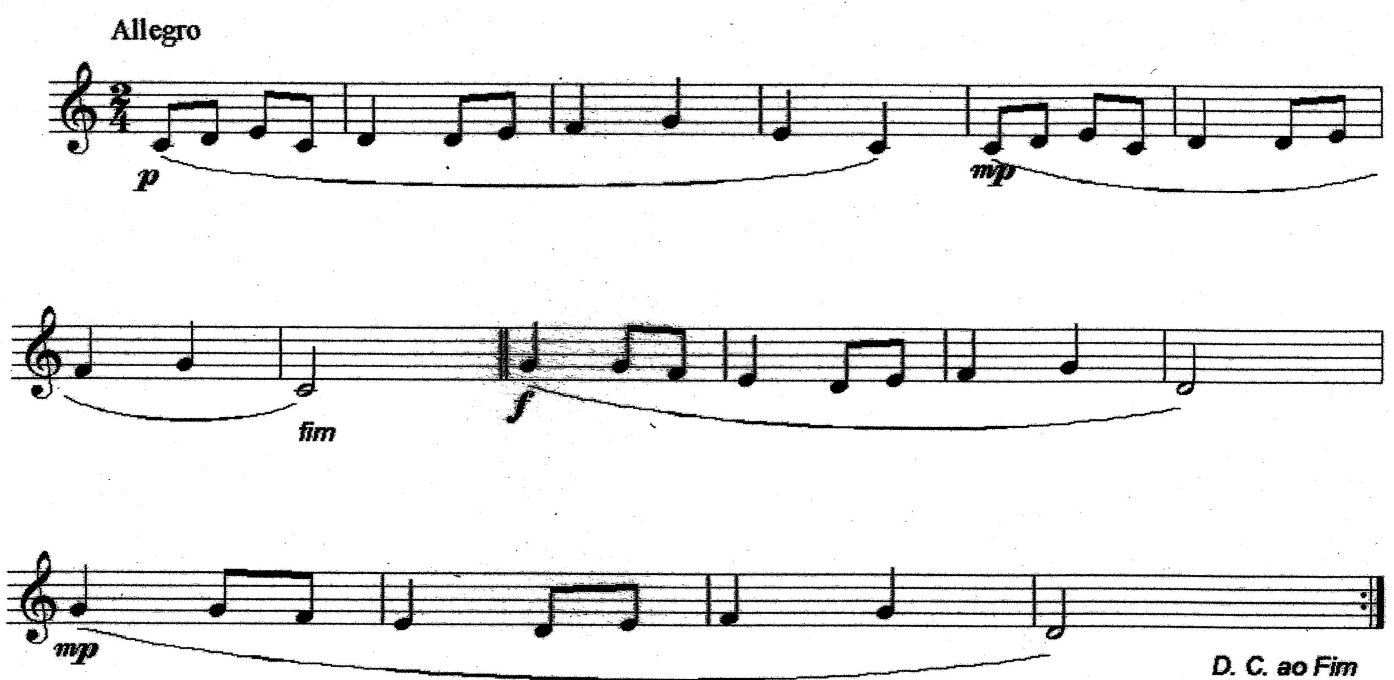
TESTE 4

111

Versão produzida pelo Delius

Teste 4 - Cancao de cinco notas 2
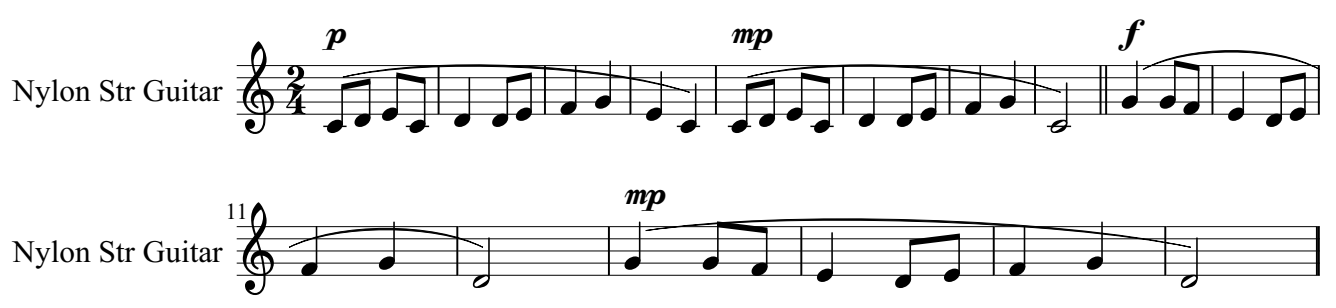


\section{C.5 Teste 5}

Original em tinta

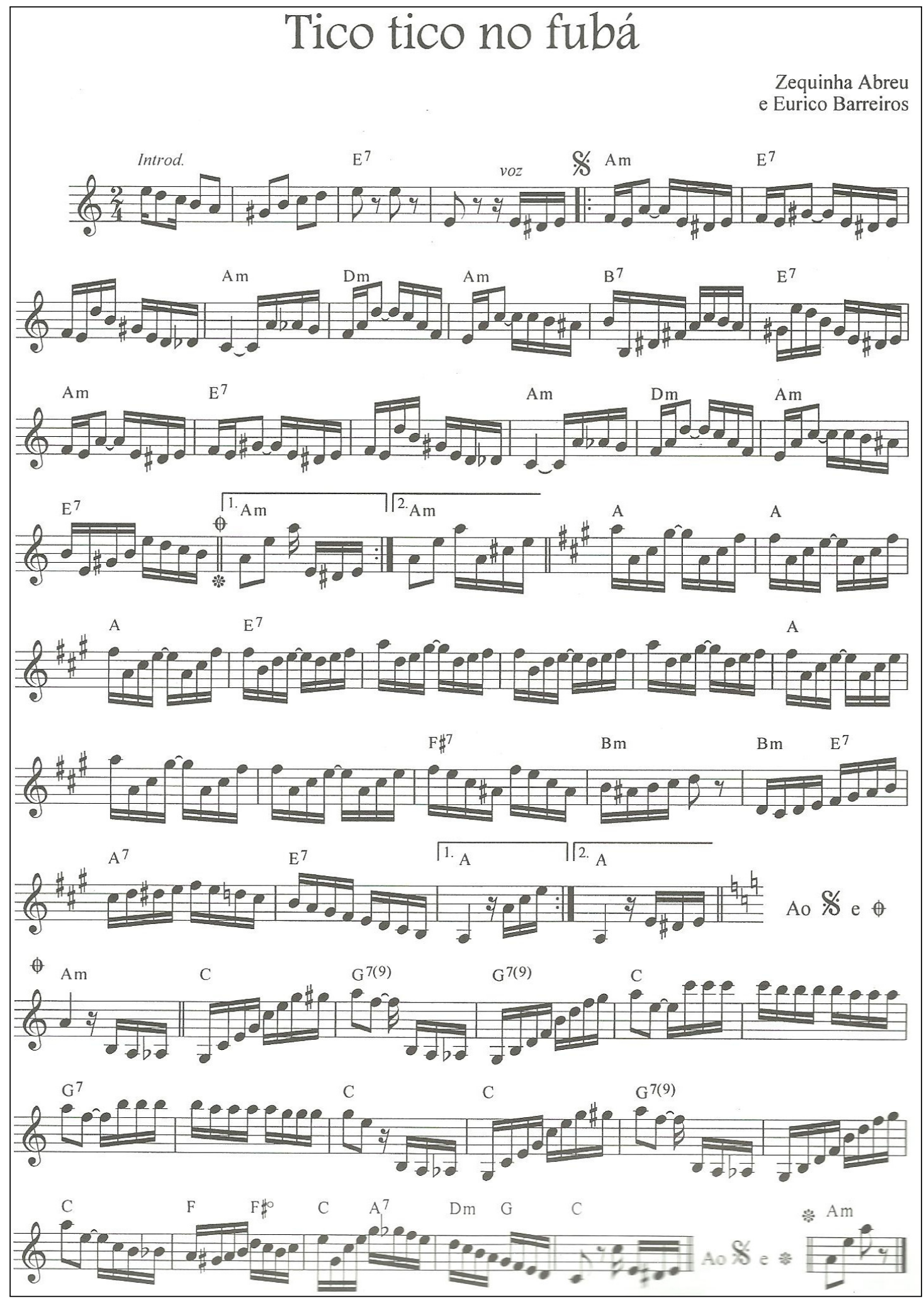


Versão produzida pelo Delius

\section{Teste 5 - Tico tico no fuba}

Jazz Gt.

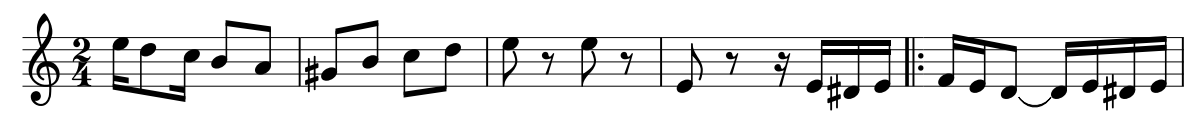

Jazz Gt.

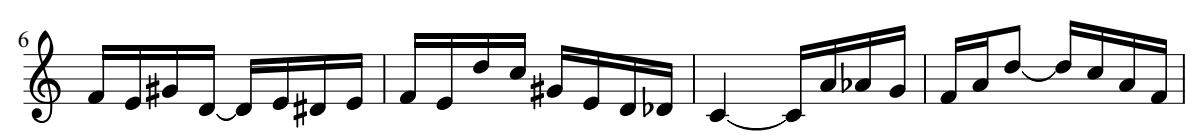

Jazz Gt.

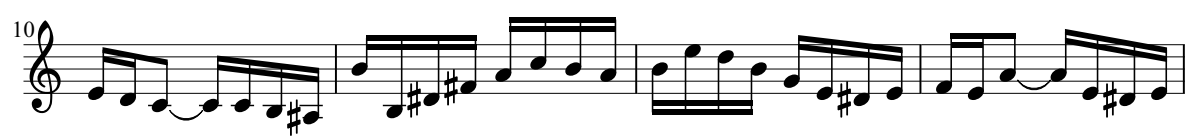

Jazz Gt.

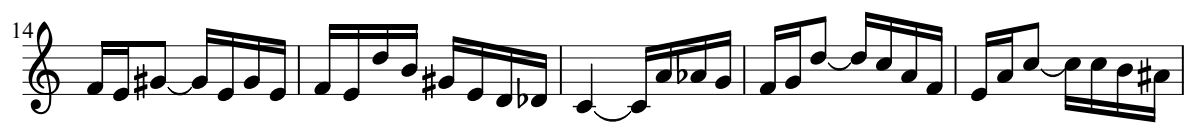

Jazz Gt.

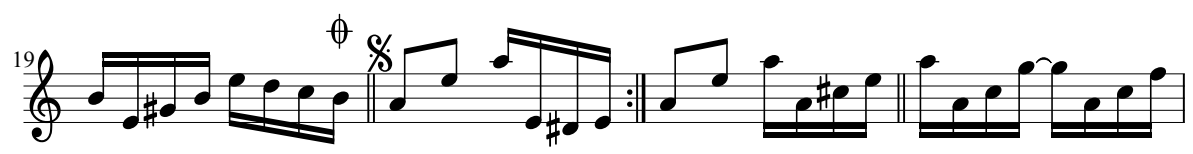

Jazz Gt.

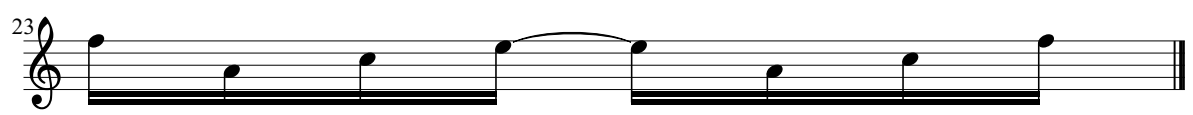


114 APÊNDICE C

Original em braille

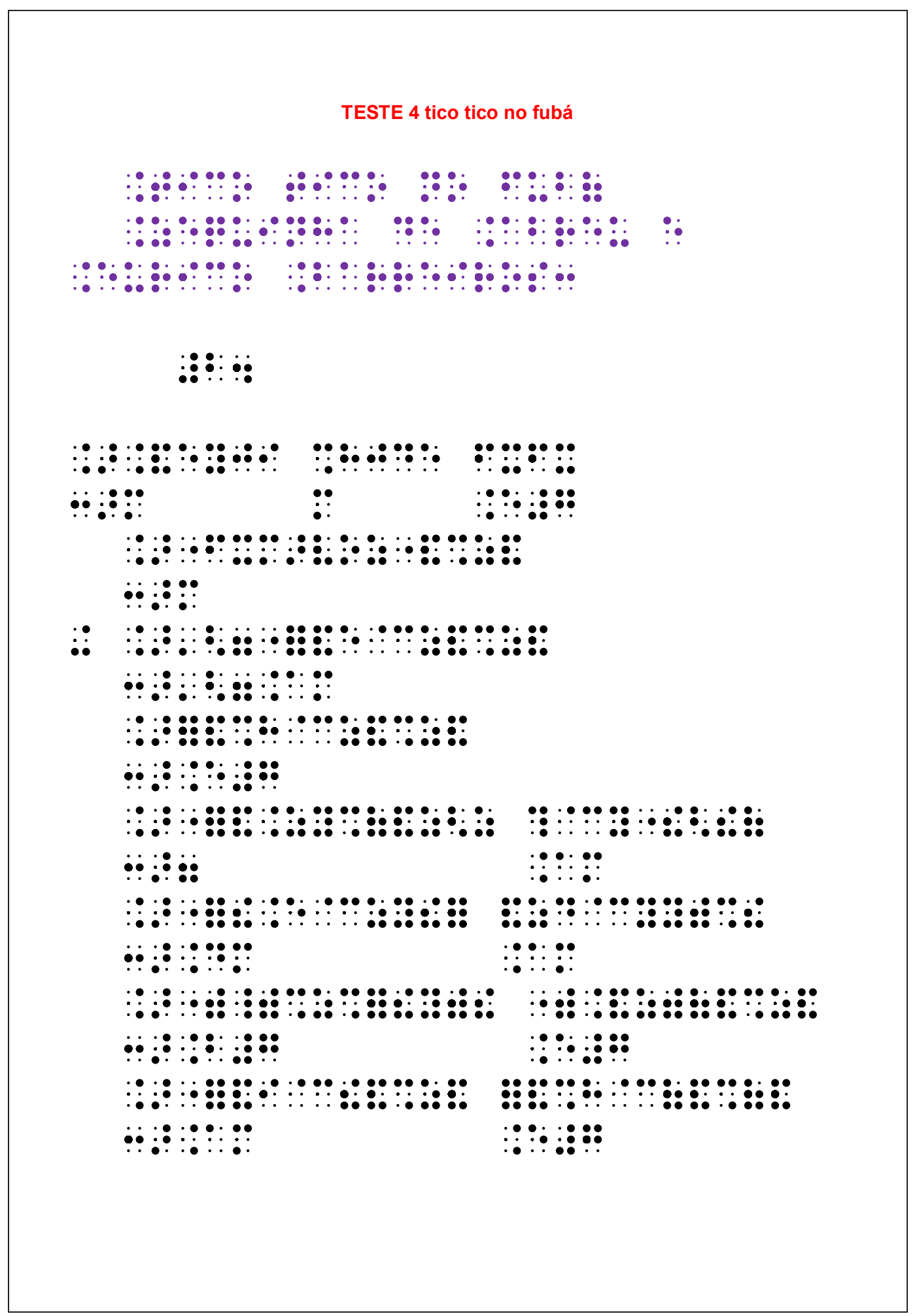




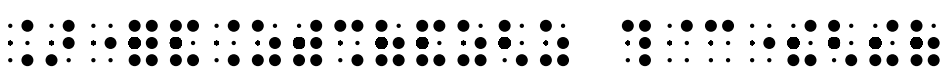

$\because: \because::$

$\because \vdots: \because \vdots$

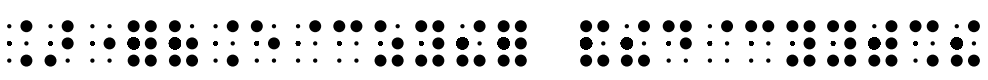

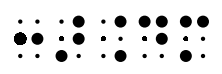

$\because: ⿱: \bullet: \bullet$

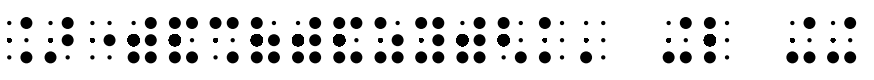

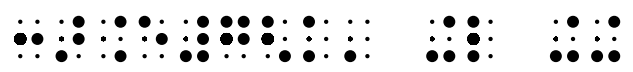

$\because: \because:$

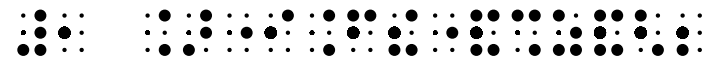

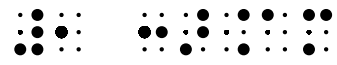

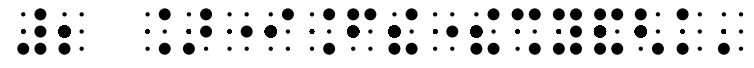

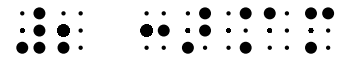

$\bullet \bullet \bullet \bullet \bullet \bullet$

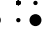

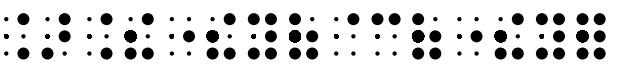

$\because: \because: \vdots: \vdots: \vdots$

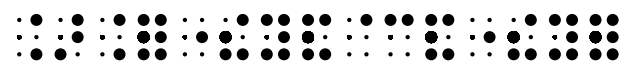

$\because: \because: \vdots: \vdots$ 


\section{Apêndice D}

\section{Descrição das regras de musicografia braille no formato $\mathrm{BNF}$}

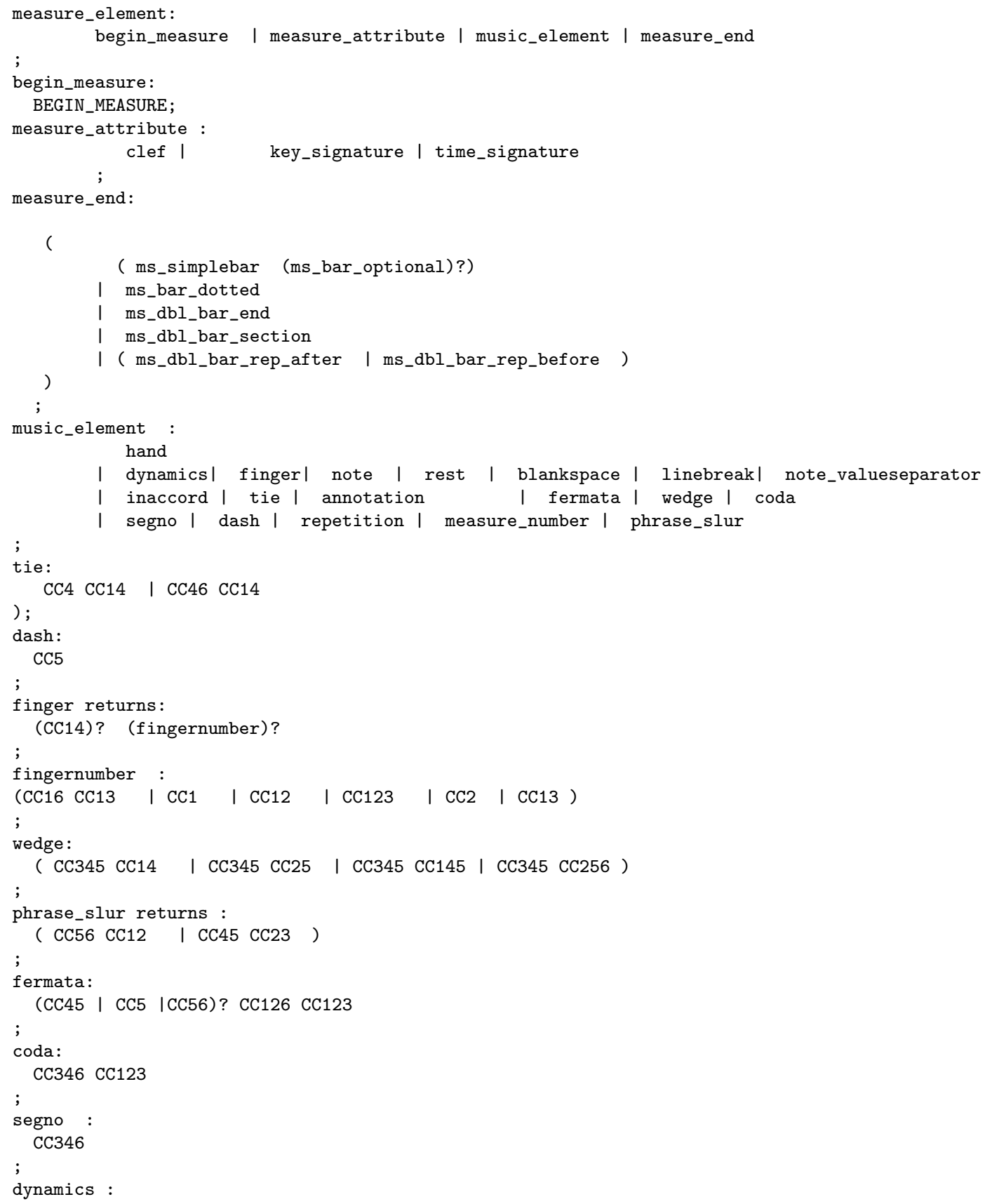


;

$\mathrm{CC} 345((\mathrm{CC} 1234)+|(\mathrm{CC} 124)+|(\mathrm{CC} 134 \mathrm{CC} 1234) \mid(\mathrm{CC} 134 \mathrm{CC} 125))$

inaccord :

$\left(\begin{array}{llll}\mathrm{CC} 126 & \mathrm{CC} 345 & \mathrm{CC} 5 & \mathrm{CC} 2\end{array}\right)$

;

repetition :

(CC3456 lowdigit (CC3)?)?

ms_simplebar: CCO;

ms_bar_optional : $\mathrm{CC} 123 \mathrm{CCO}$;

ms_bar_dotted : CC13;

ms_dbl_bar_end: CC126 CC13;

ms_dbl_bar_section: CC126 CC13 CC3;

ms_dbl_bar_rep_after: CC126 CC2356;

ms_dbl_bar_rep_before: CC126 CC23;

blankspace:

BLANKSPACE

;

hand :

( lefthand | righthand)

;

righthand :

(CC46 CC345)

lefthand :

(CC456 CC345)

;

clef :

clefSign (clefG | clefF | clefC) ;

clefG_left: CC34 CC13;

clefF : CC3456 CC123;

clefC : CC346 CC123;

clefSign: CC345;

time_signature :

((number digit lowdigit) | time_common | time_cutcommon ))?

;

key_signature:

(r1=key_sig_sharps | r2=key_sig_naturals | r3=key_sig_flats)

anyspace :

CCO I BLANKSPACE

key_sig_sharps returns :

((CC146 Inumber upnumbers CC146 anyspace);

key_sig_flats :

((CC126 Inumber upnumbers CC126 anyspace);

key_sig_naturals :

(CC16 anyspace);

upnumbers:

(digit)+

digit returns [String cell, int val] :

CC1 | CC12| CC14| CC145| CC15| CC124| CC1245| CC125| CC24 | CC245

lowdigit :

CC2 | CC23 | CC25 | CC256 | CC26 | CC235 | CC2356 | CC236 | CC35

number :

CC3456

time_common:

C46 C14 $\{\$ c e l l=" 46$ 14"; \$val="C";

time_cutcommon:

C456 C14 


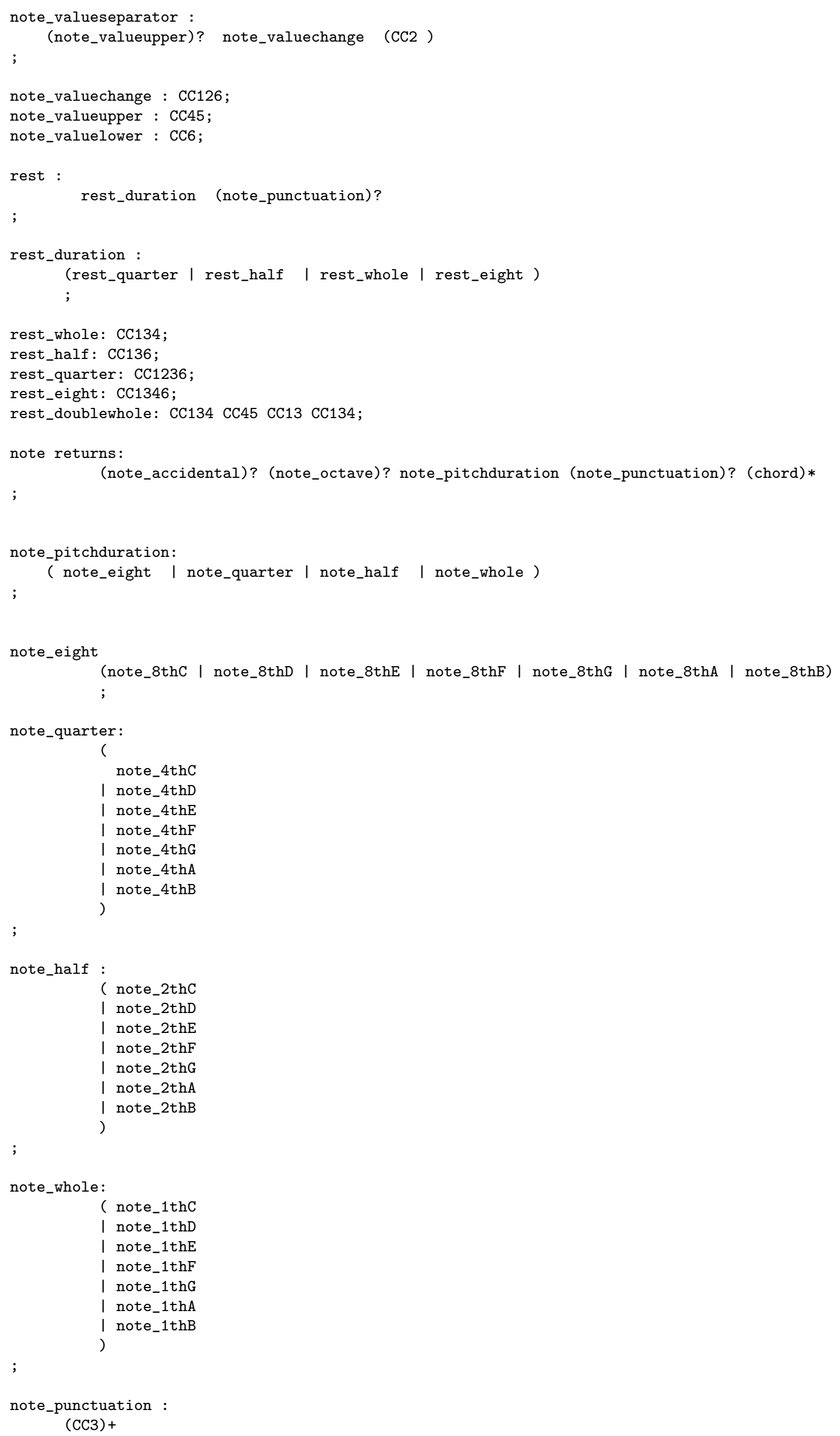




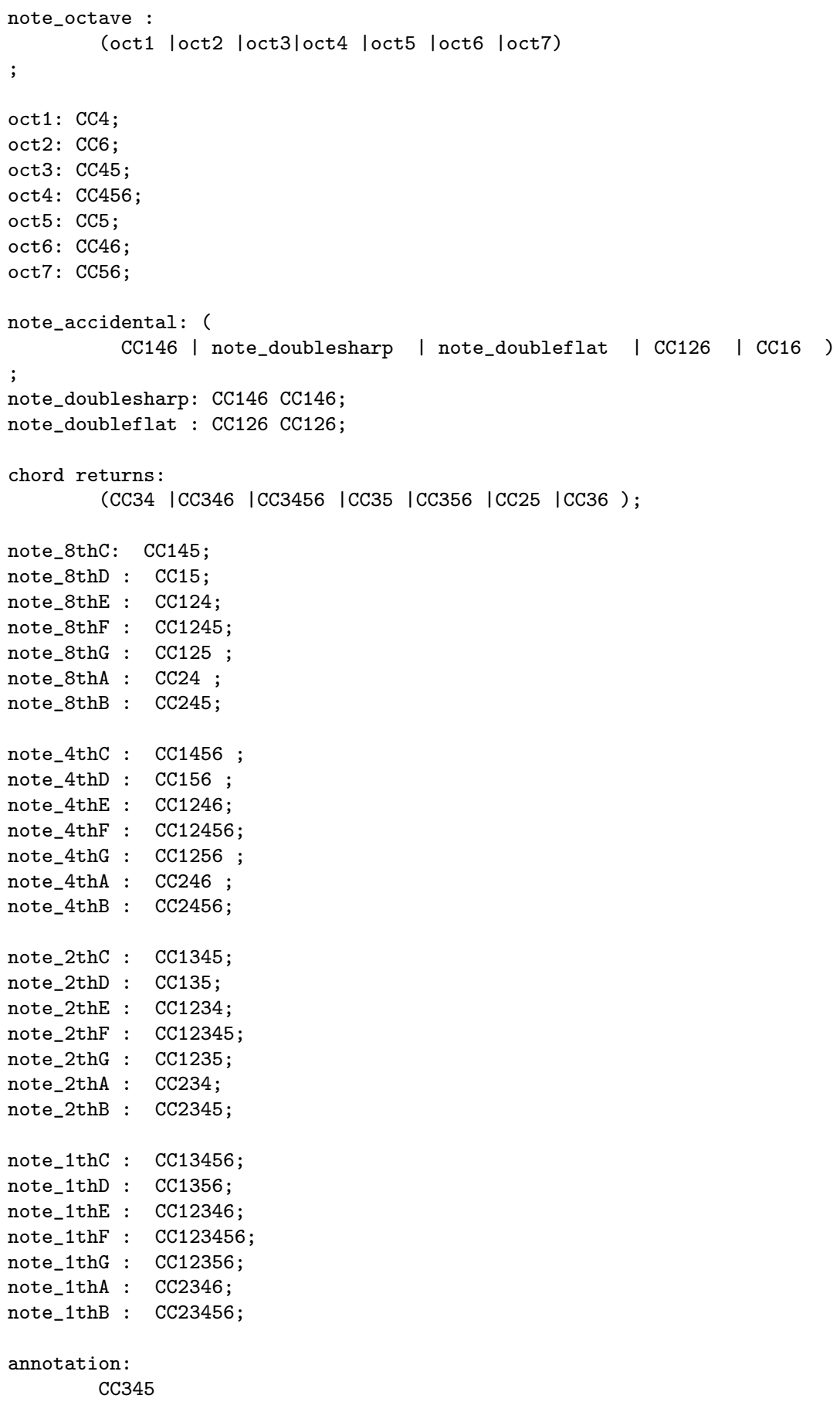


$\mathrm{CC} 14: \mathrm{C} 14$

$\mathrm{CC} 24: \mathrm{C} 24$;

CC124: C124;

CC34 : C34;

CC134 : C134;

CC234 : C234;

CC1234 : C1234;

CC5 : C5 ;

CC15 : C15;

$\mathrm{CC} 25: \mathrm{C} 25$;

CC125 : C125;

CC35 : C35;

CC135 : C135;

CC235 : C235;

CC1235 : C1235;

CC45 : C45;

CC145 : C145;

CC245 : C245;

CC1245: C1245;

CC345 : C345;

CC1345 : C1345;

CC2345 : C2345.

CC12345 : C12345;

CC6 : C6;

CC16 : C16;

CC26 : C26;

CC126 : C126;

CC36 : C36;

CC136 : C136;

CC236 : C236;

CC1236 : C1236;

CC46 : C46;

CC146 : C146;

CC246 : C246;

CC1246 : C1246;

CC346 : C346;

CC1346 : C1346;

CC2346 : C2346;

CC12346 : C12346;

CC56 : C56;

CC156 : C156;

CC256 : C256;

CC1256 : C1256;

CC356 : C356;

CC1356 : C1356;

CC2356 : C2356;

CC12356 : C12356;

CC456 : C456;

CC1456 : C1456;

CC2456 : C2456;

CC12456 : C12456;

CC3456 : C3456;

CC13456 : C13456;

CC23456 : C23456;

CC123456 : C123456;

FREE : 'FREE';

BEGIN_MEASURE : 'BEGIN_MEASURE';

TEXT_DELIMITER : 'TEXT_DELIMITER';

BLANKSPACE : ' =';

LINEBREAK : 'LINE_BREAK';

fragment CO : '-',

fragment C1 : ' 1';

fragment C2 : ' 2 ';

fragment C12 : '12';

fragment C3 : ' 3 ';

fragment C13 : '13';

fragment C23 : '23';

fragment C123 : '123';

fragment $\mathrm{C} 4$ : ' 4 ';

fragment C14 : '14';

fragment C24 : '24';

fragment C124 : '124';

fragment C34 : '34';

fragment C134: '134';

fragment C234 : '234'; 
fragment C1234 : '1234';

fragment C5 : '5',

fragment C15 : '15';

fragment C25: '25';

fragment C125: '125';

fragment C35 : '35';

fragment C135: '135';

fragment C235 : '235';

fragment C1235 : '1235';

fragment C45: '45';

fragment C145 : '145';

fragment C245: '245';

fragment C1245 : '1245',

fragment C345: '345';

fragment C1345 : '1345',

fragment C2345 : '2345';

fragment C12345: '12345';

fragment C6 : ' 6 ';

fragment C16: '16';

fragment C26 : '26';

fragment C126: '126';

fragment C36 : '36';

fragment C136 : '136';

fragment C236 : '236';

fragment C1236: '1236';

fragment C46: '46';

fragment C146 : '146';

fragment C246: '246';

fragment C1246 : '1246';

fragment C346 : '346';

fragment C1346 : '1346',

fragment C2346 : '2346';

fragment C12346 : '12346';

fragment C56 : '56';

fragment C156 : '156';

fragment C256 : '256';

fragment C1256: '1256';

fragment C356 : '356';

fragment C1356: '1356';

fragment C2356 : '2356';

fragment C12356: '12356';

fragment C456: '456';

fragment C1456 : '1456',

fragment C2456 : '2456';

fragment C12456 : '12456';

fragment C3456: '3456';

fragment C13456 : '13456';

fragment C23456 : '23456';

fragment C123456 : '123456'; 


\section{Referências Bibliográficas}

Aldred V. Aho(1986) Jefrey D. Ullman Aldred V. Aho, Ravi Sethi. Compiladores - Princípios, Técnicas e Ferramentas. Longman do Brasil. ISBN 9788588639249. Citado na pág. 63

Andrews(2010) Mark Andrews. Accessibility and the swing set: How swing can help you create accessible apps, 2010. Citado na pág. 34

Arora(2010) Nitin Arora. Beyond images: Encoding music for access and retrieval. research paper for Master's in Library and Information Science, University of Alabama. Citado na pág. 54, 55

Bannick(2011) John Bannick. Blind computer games - designing games for screen readers, 2011. Citado na pág. 36

Belarmino(2001) Joana Belarmino. As novas tecnologias e a desbrailização:. Seminário Nacional de Bibliotecas Braille. Citado na pág. 4

Bonilha(2005) Fabiana F. G. Bonilha. O uso das tic's na produção de um acervo de partituras em braille no laboratório de acessibilidade da unicamp. Em Congresso Brasileiro de Biblioteconomia e Documentação. Citado na pág. 6, 10, 30

Bonilha(2006) Fabiana F. G. Bonilha. Leitura musical na ponta dos dedos: caminhos e desafios do ensino de musicografia braille na perspectiva de alunos e professores. Dissertação de Mestrado, Instituto de Artes, Universidade Estadual de Campinas. Citado na pág. 9

Bonilha(2010) Fabiana F. G. Bonilha. Do toque ao som : o ensino da musicografia Braille como um caminho para a educação musical inclusiva. Tese de Doutorado, Instituto de Artes, UNICAMP. Citado na pág. 6, 15

Cai et al.(2000) Jason Cai, Ranjit Kapila e Gaurav Pal. Hmvc: The layered pattern for developing strong client tiers. java world online magazine,, 07 2000. Citado na pág. 43

Center for Universal Design(2006) Center for Universal Design. The principles of universal design, 09 2006. Citado na pág. 4

Clóvis et al.(2007) Silveira Clóvis, Regina O. Heidrich e Patrícia B. S. Bassani. Avaliação das tecnologias de softwares existentes para a inclusão digital de deficientes visuais através da utilização de requisitos de qualidade. Em SBIE 200\%. Citado na pág. 6

Coutaz(1987) J. Coutaz. Pac: an object oriented model for implementing user interfaces. $A C M$ SIGCHI Bulletin, 19(2):37-41. Citado na pág. 43

Cunningham(2004) Stuart Cunningham. Suitability of musicxml as a format for computer music notation and interchange. Em IADIS International Conference Applied Computing, Lisboa, Portugal. Citado na pág. 53

Cuthbert(2010) Michael Scott Cuthbert. music21: A toolkit for computer-aided musicology and symbolic music data. Em ISMIR 2010 11th International Conference on Music Information Retrieval, volume 11, páginas 637-642, Utrecht, Netherlands. Citado na pág. 55 
de Previdência Social(1991) Conselho Nacional de Previdência Social. Regime geral da previdência social. http://www81.dataprev.gov.br/sislex/paginas/42/1991/8213_7.htm, 1991. Acesso em 02 de abril de 2011. Citado na pág. 1

de Souza(2010) Rafael M. Vanazzi de Souza. A inclusão do aluno cego em aulas de música: relatos e observações. Em XIX Congresso Nacional da Associação Brasileira de Educação Musical. Citado na pág. 1

de Souza(2009) Rafael M. Vanazzi de Souza. Educação musical para deficientes visuais: Experiências no ensino da musicografia braille. Em IV Encontro de Pesquisa em Música, Universidade Estadual de Maringá. Citado na pág. 5, 16

Downie(2003) J. Stephen Downie. Music information retrieval. Annual Review of Information Science and Technology, 37(1):295-340. ISSN 1550-8382. doi: 10.1002/aris.1440370108. Citado na pág. 51

Encelle et al.(2009) Benoît Encelle, Nadine Jessel, Josiane Mothe, Bachelin Ralalason e Javier Asensio. BMML: Braille Music Markup Language. Open Information Systems Journal, 3:123135. ISSN 1874-1339. URL http://liris.cnrs.fr/publis/?id=3792. Citado na pág. 15, 26, 59

Eric Freeman(2004) Bert Bates Kathy Sierra Eric Freeman, Elisabeth Robson. Head First Design Patterns. Head First. O'Reilly. ISBN 9780596007126. URL http://books.google.com.br/books? id $=$ LjJcCnNf92kC. Citado na pág. 37, 41, 61

Good(2001) Michael Good. An internet-friendly format for sheet music. Em XML Conference. Citado na pág. 53

Goto et al.(2007) D. Goto, Toshiyuki Gotoh, R Minamikawa-Tachino e T. Naoyoshi. A transcription system from musicxml format to braille music notation. EURASIP J. Appl. Signal Process., páginas 152-152. ISSN 1110-8657. doi: http://dx.doi.org/10.1155/2007/42498. Citado na pág. 3, 9

Haus e Longari(2005) Goffredo Haus e Maurizio Longari. A multi-layered, timebased music description approach based on xml. Comput. Music J., 29(1):70-85. ISSN 0148-9267. doi: 10.1162/comj.2005.29.1.70. Citado na pág. 51

IBGE(2010) IBGE. Censo demográfico 2010: Resultados gerais da amostra. ftp: //ftp.ibge.gov.br/Censos/Censo_Demografico_2010/Resultados_Gerais_da_Amostra/resultados_ gerais_amostra.pdf, 2010. Citado na pág. 1

Inthasara et al.(2007) Aphisada Inthasara, Ladawan Mipansaen, Pichaya Tandayya, Chatchai Jantaraprim e Patimakorn Jantaraprim. Musicxml to braille music translation. Em Proceedings of the 1st international convention on Rehabilitation engineering 8 \#38; assistive technology: in conjunction with 1st Tan Tock Seng Hospital Neurorehabilitation Meeting, páginas 189-193, New York, NY, USA. ACM. ISBN 978-1-59593-852-7. doi: http://doi.acm.org/10.1145/1328491. 1328539. Citado na pág. 9

Kirk(2007) R.E. Kirk. Statistics: An Introduction. Thomson/Wadsworth. ISBN 9780534564780. Citado na pág. 76

Krasner e Pope(1988) G.E. Krasner e S.T. Pope. A description of the model-view-controller user interface paradigm in the smalltalk- 80 system. Journal of object oriented programming, 1 (3):26-49. Citado na pág. 41

Lassfolk(2004) K. Lassfolk. Music notation as objects: an object-oriented analysis of the common western music notation system. Acta semiotica Fennica. International Semiotics Institute at Imatra ; Semiotic Society of Finland ; Department of Musicology, University of Helsinki. ISBN 9789525431070. Citado na pág. 57, 58 
Likert(1932) R. Likert. A technique for the measurement of attitudes. Archives of psychology. Citado na pág. 72

Med(1996) Bohumil Med. Teoria da música. MusiMed. ISBN 9788585886028. Citado na pág. 68

Microsoft Applied Sciences Group(2010) Microsoft Applied Sciences Group. Keyboard ghosting explained! http://www.microsoft.com/appliedsciences/content/projects/ AntiGhostingExplained.aspx, 2010. acesso em 05/2011. Citado na pág. 39

Mynatt e Weber(1994) Elizabeth D. Mynatt e Gerhard Weber. Nonvisual presentation of graphical user interfaces: contrasting two approaches. Em Proceedings of the SIGCHI conference on Human factors in computing systems: celebrating interdependence, CHI '94, páginas 166-172, New York, NY, USA. ACM. ISBN 0-89791-650-6. doi: 10.1145/191666.191732. Citado na pág. 34

Núcleo de Acessibilidade Virtual do IFRS(2009) Núcleo de Acessibilidade Virtual do IFRS. Leitores de tela: Descrição e comparativo. Relatório técnico, Ministério da Educação - Secretaria de Educação Profissional e Tecnológica. Citado na pág. 6

Neto(1987) João José Neto. Introdução a compilação. Livros Técnicos e Científicos Editora S.A. ISBN 8521604831. Citado na pág. 63, 66

Newcomb(1991) Steven R. Newcomb. Standard music description language. Computer, 24(7): 76-79. ISSN 0018-9162. doi: 10.1109/2.84842. Citado na pág. 51

Portal Lerparaver(2005) Portal Lerparaver. A invenção do sistema braille e a sua importância na vida dos cegos. http://www.lerparaver.com/braille_invencao.html, 11 2005. acesso em 12 de março de 2012. Citado na pág. 16

SEE/ME(2002) SEE/ME. Grafia Braille para a língua portuguesa. Ministério da Educação. Secretaria de Educação Especial. Citado na pág. 2, 16, 85

SEE/SE(2007) SEE/SE. Atendimento Educacional Especializado - Deficiência Visual. Ministério da Educação. Secretaria de Educação Especial. Citado na pág. 5

Smith et al.(2004) Ann C. Smith, Justin S. Cook, Joan M. Francioni, Asif Hossain, Mohd Anwar e M. Fayezur Rahman. Nonvisual tool for navigating hierarchical structures. Em Proceedings of the 6th international ACM SIGACCESS conference on Computers and accessibility, Assets '04, páginas 133-139, New York, NY, USA. ACM. ISBN 1-58113-911-X. doi: 10.1145/1028630. 1028654. Citado na pág. 37

Sun Microsystems Inc() Sun Microsystems Inc. Java accessibility:explanation of the java accessibility api interfaces and classes. http://docs.oracle.com/cd/E17802_01/j2se/javase/technologies/ accessibility/docs/jaccess-1.3/doc/core-api.html. acesso em 04 de maio de 2012. Citado na pág. 34

Tomé(2003) Dolores Tomé. Introdução à Musicografia Braille. Ed. Global. Citado na pág. 16

União Mundial dos Cegos(2004) União Mundial dos Cegos. Novo manual internacional de musicografia Braille. Brasília: Ministério da Educação. Secretaria de Educação Especial. Citado na pág. $3,16,25,27$

Van Hees e Engelen(2010) Kris Van Hees e Jan Engelen. Puir: parallel user interface rendering. Em Proceedings of the 12th international conference on Computers helping people with special needs: Part I, ICCHP'10, páginas 200-207, Berlin, Heidelberg. Springer-Verlag. ISBN 3-64214096-3, 978-3-642-14096-9. Citado na pág. 34 